5

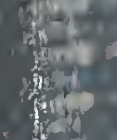

te

is

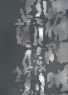





\section{ENGLisH AND MUSKOKEE}

in

$99 /$

$2547 X$

DIC'TIONARY.

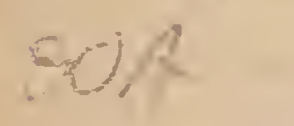

\section{COLLECTED FROM VARIOUS SOURCES}

AND REVISED,

BY

REV, R, M, LOUGHRIDGE, D, D,

MISSIONARY TO THE CREEK INDIANS, AND

ELder DAVID M, HODGE، INTERPRETER،

$\therefore$ BUREATJ OF

AMERICAN ETHAOLOGY.

Creek Mission,

INDIAIT TEREIIORI.

15102

1890.

Printing House of J. T. Smith,

11 Bridge Approach, St. Louis. 


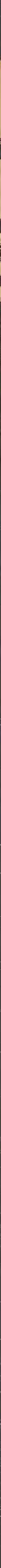




\section{MUSKOKEE ALPHABET.}

A. a. always broad as in far, as aha, afke.

C. c. che for ch as ceme, Cesvs.

$\overline{\mathrm{E}}$. $\bar{e}$. long as in meet, as likēs we sit.

E. e. short, as $\mathrm{i}$ in pin, as este a person.

F. f. as in English.

H. h. as in English.

I. $i$. always long as $i$ in pine.

K. k. as in English:

L. 1. as in English.

M. m. as in English.

N. n. as in English.

O. o. always long as in note, ofv, opv.

P. p. as in English.

R. r. hle, for hl. as rvro for hlvhlo.

S. s. as in English.

T. t. as in English.

U. u. as oo in mood, as hoktuce.

V. v. as u in but, tub as ekvnv.

W. W. as in English.

$\mathrm{Y}$. y. as in English.

\section{DIPHTHONGS}

Æ. æ. as in Aha, æla.

AU. au. as ou in out, vhaukè.

EU. eu. as in vcakateu.

OU. ou. as in cukou.

UE. ue. as in Uewv.

NoTr.-This alphabet was adopted by many Interpreters and Chiefs of the Nation at the Old Agency in I853, as the Alphabet of the Creek Language. 



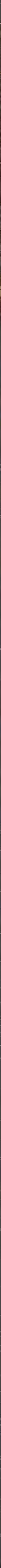





\section{PREFACE.}

This book is the result of improving the odd moments for many years, in cullecting together the words of this wonderful language.

The beginning of it was a small collection of words by REv. JoHN Fleming, the first Presbyterian Missionary to the Creeks, in I832, after they moved west of the Mississippi. To that collection I have been making additions from time to time, as opportunity offered, in connection with my many duties as a minister to the people, and superintendent of several boarding schools among them.

In sending forth this Dictionary to the public, I am fully aware that it is fur from that state of perfection so desirable in a Lexicon. But as we learn from the history of all Dictionaries, they are like young children growing up to manhood: they must pass through many changes, additions, corrections and eliminations before they attain to the maturity and perfection of Webster's great Unabridged.

Believing, therefore, that this English and Muskokee Dictionary will be of immense advantage to all the Indians, and white people, in the country, and a very important book for all the schools in the nation; I respectfully recommend and dedicate it to the Muskokce people, among whom I have spent the best years of my long life.

R. M. LOUGHRIDGE,

Red Fork, Indian Territory. 


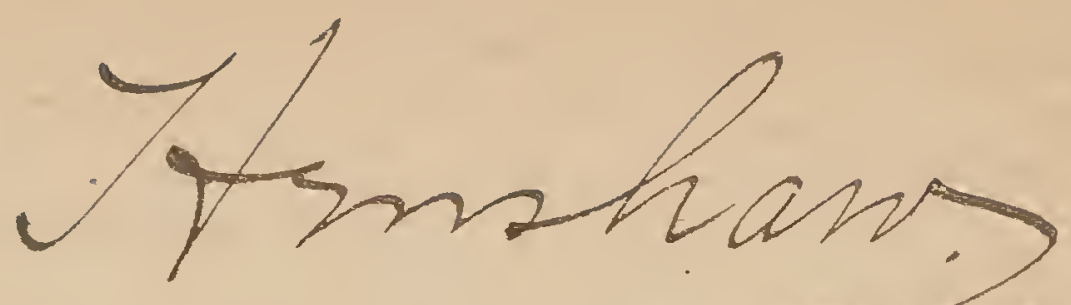

DICTIONARY.

BURERTJ OF

AMERICAN ETHNOLOGY

1909

IN TWO PARTS

LS PHAFY

1. 51.20

ENGLISH AND MUSKOKEE

AND

MUSKOKEE AND ENGLISH. 


\section{ENGLish AND MuskokeE}

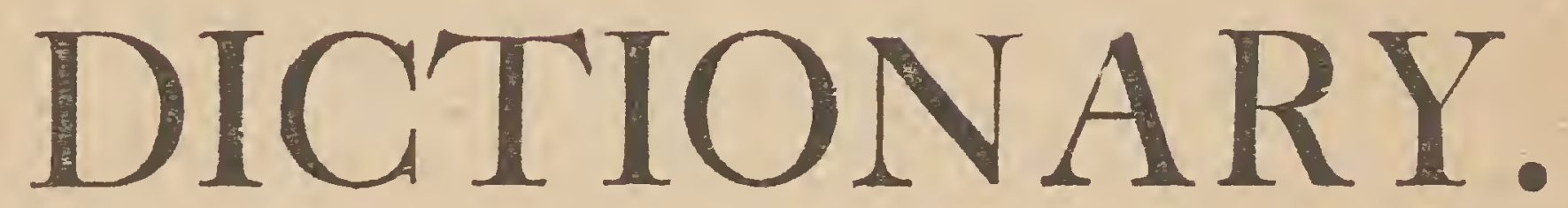

\section{- $\mathrm{ABA}$}

$A$ is always broad, pronounced as in far.

Abase, Kvncvpúecetv.

Abcess, Léce.

Abdomen, Nvr'ke.

Ability, Yekcetv'.

Abode, Liketv. Hute.

to Abolish, Res-póyetv.

Aborigines, Homeyecrlke.

About here, Yv'mv. Yomat.

About (so much), Vlke.

About to be, Momvrános.

Above (on high), Hvlwen.

Above (i. e., up stream), Arepv. Abraham, Eplehv'me.

Absent, Enkvpr'ke.

Accident, Momes-kom'eskon.

Accidental, Momes-kom'okon.

to Accompany, Cvkketo.

According to, Acvkáye.

Account, Esker'retv.

Account-book, Nakcókv-esker. kuec'kv.

to Account for, Ensátetv.

Accursed, Oh-tvhihokē.

to be Accursed, Oh tvhihóketv.

Accusation, Es-vn rvpkv.
$\mathrm{ACC}$

to Accuse, Vnrvpetv, Nak-stencetayeóketv.

to Accuse, Vtáwetv.

to Accuse falsely, Ohláksetv.

to Accustom, Svmonh-hayetv.

to Acknowledge, Kerkúecetv.

Acorn, Lak-cvpē-en-lokcv. Lok$\mathrm{cv}$.

Acorn (of White-oak), Kvlv. Acorn-mush, Lokcv-afke.

Acquaintances,' Tekerhoyvl'k to be Acquainted, Teker'retv. an Acre, Satkv rakko.

Across, (as saddle-bags), Vwelep'ke.

Across, (beyond), Apalhvm'ke. Active, Tahopke.

to Add, Oh-vpóyetv.

" "Soh-vpóyetv.

" " Toh-kv'letv.

" "O Oh-apvketv.

" " Oh-atvláyetv.

Adder, Tor-opvt'kv. Adjure, Pohepetv.

Adulterer, Hoktárv. Adulterous, Hoktáre. Adultery, Hoktárkv. 


\section{ADU}

to commit Adultery, Hoktaretv. Adversary, Rapv. Vnrapv. Advertise, Eskerkúecetv.

Advocate, Fvtcécv. to Advocate, En-fvtcécetv. Adze, Vcuknv.

Afar off, Hopiye.

Affirm, Mehenwetv-vtékat.

Afflict, En-nokkic'etv.

Afflicted, Estemer ke. Estemerkv'ke.

Affliction, Estemerkv.

to Affright, Penkvlec'etv.

to be Afraid, Penkvl'etv.

A frican, Este-lvste.

After, Acvkáye.

After awhile, Hvteh'tvsen. Hofúnof.

After its kind, Em etvpómet. Afternoon, Fvtcv-lik-hoyánen. After this manner, Hiyomen. After you or thee, Cenyúpv. Afterwards, Ren-yupvn. Enyupv. Roh-yupv.

Again, Mohmet. Mont. Hvtvm. Hvtvm-mo.

Against, Vnrape.

Against each other, Tenrápe.

Against you, Tecoh.

to be Against, Vnrápetv. Vnrapv ketv.

Age, Vculkv.

Aged, Vcúle. Hóktvlé.

Agent, Este-cako.

to Aggravate, Naoric'etv.

to Agitate, Vwicec'etv-seko.

Agony, En nokke. Cvpóruse.

to Agree with, Setem-fvt'cetv. to Agree with, Etem-akvsvm'etv. Agreeable, Mvtis. Estónkos.

Agreement, Tem-fvtcetv.

Ague and Fever, Hepetke. Etkulkv. Etkólet.

to Aim, Vraketv.

Air, Hotvlé. Hvlwe fullan.

\section{ALA}

Alabaster, Alepástv. to Alarm, Feksumecic'etv. Alas, Aeha! Aela!

Alder, Coskelēpv.

Alike, (i.e., parallel), Vpvtvt'vkē. Alike, (i. e., similar), Matvpómen.

Alive, Hesáke. Wenáke.

All at orce, Etemvpvlwusen.

Ayvkhvm kv.

All about, Hvm kv.

All, Omvlkv. Vtékat. Vliket.

to Allay, Fekhunnic'etv.

to Allege, Máketv.

Alligator, Hvlpv'tv.

A little while, Hvtétusat.

to Allot, Es kerkúecetv.

to Allow, Em akvsvm'etv. Emetektrnécetv.

Allspice, Spískucē.

All-to-gether, Ayvkhvmkv.

Ally, Cuko-tempálusat.

Almighty, Yékcetv-omvlécv.

Aimust, Momvrános. Kahónkv. Alms, Herom kv.

to give Alms, Herom'etv. Estēmetv.

Alone, En-tvl'kuse. En-hvm'kuse. to be Alone, Vpáketv. 'Tulkúsetv. Alphabet, Nakcókv-lvlúnkv. Already, Entis. Hoyvnēps. Also, Mawéh. Esyómeyat. Tis. Altar, Altv: Oh-nekric'etv. to Alter, Mvrakkuécetv. Although, Momis. Tomis. Always, Emúnkv. Estófis. Ambassador, Este-em-wiketv. to Amaze, Estomáhetv. Ambition, Ehrweckkv-eyácetv. Ambitious, Ekvsvm'e. Trhokpetv.

Amen, Emeñ. Mómekvs. America, Wacēna. Americans, Wacenvl ke. Amidst, Vpáket. 
$\mathrm{AMO}$

Among, Vlkaten. Vlkan. Vpaket. an Amulet, Trkhv'ketv.

to Amuse, Afvtcecic'etv.

Animalcule, Wenahókuce.

Ancestors, Purke-tate.

Anchor, Se-hvlvtkv.

Ancient, Vcule-máhe.

Ancients, Hofunvlike.

Ancle, Toktúsw

And, Momen. Esyomat. Hvtvm.

Tis.

And, Tepyic'et. Esymo'eyat.

And I, Tepákeyat.

And-then Mohmen. Mohmet.

Andiron, Efv-cuto.

Andrew, Vntolo.

Angel, Sarv.

Hvlwe-este.

Anger, Cvpvk ketv.

Angle, Kvnawv.

Angles, Towek lepa.

Angle-worm, Semvk-wikv.

Angry, Crpvk'ke.

be Angry, Crpvk ketv.

to make Angry, Crpvkkuécetv.

Animals, (eatable) Punvttv.

to Animate, Cvfeknic'etv.

Ankle, Toktus'wv. Elle-toktus'wv.

Ankle-bone, Toktus'wv-fune.

Ankle-joint, Tokirs'wv-tehtekákv.

to Annex, Apvk'etv. Apvkepáketv.

to Annoy, Naoric'etv.

to Annul, Ehaperkícetv.

to Anoint, Vfeyetv. Vpen'etv.

to Anoint with, Svm-vfēyetv.

Anodyne, $\mathrm{F}_{s}$-nuciceckv.

Another, Etv. Etuse. Etimv. Another language, Celok'etv.

Another way, Etvmímvn. Etimv. to Answer, Ayvpos'ketv. Oketv. to Answer back, Pvlketv. Answering back, Pvlke. Ant, Tokocá.
ANT

Anthem, Yvhiketv-hēra. Anvil, Cvto-oh-pac'etv. Anvil-block,Cvto-oh-pac'etv-eto. Anxious, Mvlos'te.

to be Anxious, Mvlostvk'etv.

Any-how, Estonk'on.

Any-more, Svnvc'omv.

Any-one, Estímvto. Estomísem. Any-thing, Nake-estómis.

Any-way, Estv'mvtis.

Any-where, Stómis.

Apart, Ete. Etem. Eten. Svlvhwe.

Apart-from, Kvpvk'e. Tekvpvk'e. to be Apart, Kvpvk'etv. Entvlketv.

Ape, Wotko-este-rakko.

Apoplexy, Cate-esok'ce.

Apostacy, Mekusvp'kv-wiketv. to Apostatize, Mekusvpkv-wiketv. Apostle, Apástel.

Apostles. Acvk-fulvl'ke.

to Appear, Hecketv. -vketv.

Appearance, Heckv.

to Appease, Herkv-hayetv.

to Applaud, Akvsvm'etv.

Apple, Svtv-rakko.

to Apply, Svfvs'tetv.

to Appoint, Melletv.

Appointment; Melletv.

Apprentice, Emelicv-huere.

to Approach, Eme-heckúecetv.

to Approve, Em-a-kvsvm etv.

Apricot, Opvkv.

April, Tasáce-rakko.

Apron, Homvpackv, homv-sohpackv.

Apron-string, Homvpackv-fvkv. Arch-angel, Sarv-kapetvn'e.

Arch-angel, Hvlwe-tvlofv-estvlkekapetvn'e.

Archer, Ecvkotak'se-em-vnoc'ke. Ardent, Hēret, Hiyuse.

Arduous, Hērvron'ks. Hēretv. 


\section{ARI}

to Arise, Ahueyiretv. Kvwapketv. Akvwápetv.

to Arise, from, Aliketv, Akáketv. Avpóketv.

to Arise from, Akayápketv. Akvyvpetv.

to Arise (stand up) Ahuéretv.

" "Sehóketv, svpákletv.

Arise-with, Askawvp'ketv.

Arithmetic, Nakcokv-vhonkvtetv.

Ark, Pero-cuko.

Arkansas-river, Uecáte.

Arm, Svkpv.

Armor, Setepokv.

to Arm-one's-self, Se-etetakúecetv.

Arm-pit, Svk-pvklicv.

Arm-hole, Svkpv-mvháuke.

Around, Ra. Ras. vkúluke. Fulot'ke, vfulot'ke.

to go Around, Ra-ayetv.

Arrange, Evtcēcetv. Tvlvlic'etv. Arrow, Re.

Arrow-point, Re-semohpik'v. Arrrow-winged, Re-cvlohe.

Arrow-root, Kunte, Arrow-root. Pulv. Kunte-vktake. Arrow-wood, Re-hakv.

Artery, Feke-fvkv.

Articles, Nanvk'ose.

As, Tisem, Tis. Omat, momen, mimv. Unkv.

As for me, Vn-tvnomat.

As many as, Estomómuset.

As, the same as, Etvpomet, Tis. As well as, Momvre-hēren, Etvpomen.

to Ascend, Hvlwécetv.

to Ascend, Akvwvp'ketv.

Ascension, Akvwvp'ketv.

Ashamed, Vleske. Vlsose.

to be Ashamed, Vlesketv. Vlsetv. Ash-box, Essu-vtehkv.

Ash-bread, Tvkhopélke.

\section{ASH}

Ashes, Essu, Trk-ēssu.

Ash-leach, Kapúsko.

Ash-tree, Eto-hvtke.

Aside, Wvnen, awvne, awvn'use. to Ask, Vpohetv, 'vketv.

to Ask a blessing on, Ohmekusápetv.

Ass, Corakko-pihkv, Corakkowahkvpikv.

to Assemble, Toh-vtelóvetv, Tohvtelóketv, Nakv'ftetv, Tohkvlketv.

Assembly, Nvkáften, Vtelokv. to Assent, Em akvsvm'etv.

to Assert, Kerkúecetv.

to Assist, Vnic'etv.

to Assist, (in rising) Ahueric'etv. Assuage-crying, Akorpic'etv. Asthma, Hesaketv-ēléce. Astringent, Tukfe. Asunder, Ete. Eten, Etem. At, Liks. Ohfvt'cv. At-home, Huten.

At last, Mohmen. Respókof. Athirst, Ewvnhke.

Atmosphere, Hotvle

Atonement. Pume-temfvt'cetv. Attached to any place, Vwos'ke. to be Attached to. Vwos'ketv. to Attend to, Afvs'tetv. Svfvs'tetv. to Attend to it, Mafvs'tetv. At that time, Mvketekof. At the same time, Mvketēken. At times, Momen-ocof. Auctioneer, Es-huehketv.

Auger, Es-polkv.

August, (month) Hiyo-rakko.

Aunt, (of a female) Posē.

Aunt, (of a man) Etskucē.

Authority, Yek'cetv.

Autumn, Rafo-hakof.

to Avow, Eme-wik'etv.

Awake, Vhonēce.

to be Awake, Vhonécetv. 


\section{AWA}

to Awaken, v. c. Vhonecic'etv.

Away, Vsvn, Ye.

Away-off, Hopíye.

Away-yonder, Rahopíye. mahe.

Awful, Sehonec'ke.

Awkward, Nak-kerreko.

Awl, Cofun'wv.

Axe, Pucus'wv.

Axe-helve, Pucuswv-mrpe.

Axle-tree, Tohkakv.

\section{B.}

Babe, Estuce. Hokosē.

Baboon, Wotko-este.

Bachelor, Ehiwv-seko.

Back, (upper part) Era, Rvtce.

Back, (lower part) Cvietackv.

Back-band, Era-sohwe-lepkv.

Back-bone, Era-fune.

Back-log, Tvk-hvce.

Back of the hand, Enke-topvrv.

Back of the head, Ekv-topvrv.

Back of the neck, Nok-topvrv.

Backslidden, Acekelle.

to Backslide, Acekelletv, Acekelhóyetv.

to Backslide, v.c., Acekelhúectv.

Backslider, Acekellv.

Backwater, Uewv-acekellet.

Bacon, Tosennv.

to be Bad, Holwáketv. Holwahóketv.

Bad, Vholwake. Holwake. Holwahoke

Badger, Ëskv.

Badly, Holwaken.

Bag, Sukcv.

Bag (of a cow) Epesse.

Bagging, Sukcv-es-hakv.

Bails, Eswvnvke.

to Bait, Enkvnhetv.

to Bake, Noricetv.

Baker, Noricv.

\section{$\mathrm{BAK}$}

Bake-kettle, Elle-oca. Tvklikeesnorickv.

Bake-oven, Eskopetv-lekiyv.

Bake-pan, Eshotopkv-sehiyv.

Baking-powder, Tvklike-espakkuec'kv.

Balance, Upvlwv-svtarkuec'kv.

Bald, $\mathrm{K}$ rofke. Esse-seko. Lemke. Rofke.

Bald-eagle, Hvtke-tekfvn'kv.

Ball, Pokko.

to play Ball, Pokkec'etv.

Ball-play, Pokkec'etv.

Ball-play-conjurer, Pokkecvlke. vlékcv.

Ball-play-ground, Hiyakpo-hute. Ball-sticks, Tokon'he.

Balm, Heles-fvmēcv.

Bank, Vkvlálvke.

to Banter, Em-ekvsámetv.

Baptism, Paptesvm. Uewv-oh-

fesketv. Ak-súmketv.

to Baptize, Paptisetv.

to be Baptized, Paptichoketv.

Bar (of sand) Okta-hvtke.

Barb, Enlak'he.

to Barbecue, Hotópetv.

to Bargain, Temfut'cetv, 'vketv.

Ten-fvt'cetv.

Bark, Eto-hvrpe.

Bark (outside) To-hvrpe.

to Bark, Wohketv.

Barley, Teleko-vhake.

Barn, Tohto. Nerkv-hute.

Barrel, Towvnv'ke.

Barren, (a person) Echus-seko.

Barren (a tree) Etteko.

Barrens, Svloh-tofvn.

Barrow, (a hog) Sukhv-teho.

Bars (of fence) Svkhotkv.

to Barter, Seteyopósketv.

Bashful, Vlsē.

Bashful, (to be) Eyvtuécetv.

Basin, Vkulhe-uewv-lekuthe. 


\section{BAS}

Basin, Este-turofv-palvknē-okoskv.

Basin, Palvknv-sokoskv。

Basket, Svmpv. Svkkv.

Bat, Tvkfeleléskv.

to Bathe, v. c., Aklopec'etv.

to Bathe, Akvlop'etv.

Bath, Aklopetv.

Battle, Tepokv.

to Bawl, (as a cow) Haketv.

Bay, (color) Cate-ome.

Bay, (water) Ue-lekuthat.

Bayonet, Cvfunfvs'ke.

to Be, Sasetv. Ometv. Roretv. Toyetv.

to Be within, Epiketv.

Beach, Ote.

Beaded-pouch, Sukcv-hotcv.

Beads, Kunawv.

Beak, Nalok-fvn'wv.

Beam, Tohkakv. Cuk-elle-rakko.

Bean, Tvlako.

Bean bush, Tvlako-sewvp'ko.

Bean-pole, Tvlko-encakheckv.

to Bear-abuse, Oh-weten'etv.

Bear, Nokusē.

to Bear, (fruit) Ettuecetv.

to Bear, (as fruit) Hayetv-cohwiketv. Vnkvsvmecic'etv.

to Bear, (on himself) Eoh-wiketv. Wihetv.

to Bear up, (as in water) Okotafécetv.

to Bear up, Kawvp'ketv.

Beard, Cukesse.

Bear-grease, Nokuse-en-neha. Beast, (tame) Punvttv-yvmvs .

Beast, (wild) Punvttv-semvnolē. Beat-up, Kafake. Kafayetv. to Beat, (to hammer) Patcetv. " " (in a mortar) Hocetv. " " (to smash)Telekmícetv. " " (to thresh) Wasketv. " " off, (to fan), Ak-tonetv.
BEA

to Beat as fine powder, Lupot. ketv.

" " the air with hands, Yvwe-yiyetv.

to Beat the drum, Tvmvmv'pkvnáfketv.

to Beat, (whip) Rokáfetv.

Beautiful, Hēruse.

Beaver, Echaswv.

Beaver-dam, Echas-like.

Beaver-skin, Echas-hvrpe.

to Be-born, Hecketv. Heckvketv. Because, Tokv. Tok. Kv. Vrahkv. Munkv. Tómekv.

Because-not, Kokv. Kok. Ok. Okv.

Be clean, Hvsvttetv-hakes.

to Become, Haketv.

Bed, Topv. Pvtakv.

Bed-bug, Topv-etskv. Esteyokpv。

Horemahtvke. Estakkv.

Bed-clothes, Topv-ohpvtákv.

Bed-cord, Topv-fvkv-setehvlatkv. Bed-curtain, Topv-enhonnv.

Bedding, Ohpvtak'etv.

Bed-room, Topv-hute. Ennvthofv.

Bedstead, Topv-sohric'etv.

Bedquilt, Topv-telúmha.

Bee, Fo.

Beef, Wakv-vpeswv.

Beehive, Fo-hute.

Bee Martin, Fo-lokv.

Beer, Uetókse.

Beeswax, Fo-neha.

Beet, or Raddish, Lalunkv-cate. or Yvlunkv-cate.

Beetle (a bug), Sokcv.

Beetle (a pestle), Eshocetv,Svnafketv.

to Be-everywhere, Hrmketa-ret. ometv.

to Befall, Nak-em-mohmetv.

Before (in time), Komunken. 


\section{BEF}

Before, Ehomv. Homv. Before long, Hofune-seko. to Befriend, Tenhes'setv.

to Beg, Apohetv, Enkusv'petv.

to Beg, (be greedy), Akusvpetv.

to Beg, Akusvpécetv, v. C.

to Beget, Sícetv, Káyetv.

to Beget, Eheckuehócetv. Hecketv.

Beggar, Nak-apóhv.

to Begin, (Alicetv, 'vketv, Vlicécetv, v. c.

Beginning, Vliceckv, Enhvteces'$\mathrm{kv}$.

Behind, Yupv. Topv'rv.

Behind something, Svfvtcr.

Being as, Etvpómat, Etvpómetv.

to Be in the midst Vpaketv.

to Believe, Akvsvm'etv.

to Believe on, Oh-akvsvm'etv.

Believer, Akvsámv.

to Believe upon, Oh-akvsvm'eiv.

Bell, Cvmp'cakv.

Bell-collar, Cvmp'cakv-fvkv.

to Bellow, Hehketv. Haketv.

Bellows, Es-pofucic'kv.

Bellows-handle, Espofucickv-emvpe.

Bell-rope, Crmp'cakv-fvkv.

Bell-tongue, Cvmpcakv-tulas. wV.

Belly, Nvrke.

Beloved, Vnokec'ke.

Below, Kvncv'pv, Hvcátv.

Below, (d wn stream), Atv.

Bench, Ohlik'etv-capke.

to Bend-by, Svpenútetv.

to Bend, v. c. Kunhícetv, Pekócetv.

to Bend, (fold), Pekúecetv, Tepvkócetv.

to Bend, Kusíhetv, Kotvksec'etv.
$\mathrm{BEN}$

to Bend together, Tepoktícetv, Teprkócetv.

Beneath, Ellēcv, Lecv.

Benefactor, Heromákan, Mvni$\mathrm{cv}$, Epufas'tv.

Benefit, Nake-enlopihoce, Svnheric'etv.

Benevolence, Herom'etv.

Benevolent, Enlopice.

Bent, Kunhe, Kotvk'se.

to be Bent, Kun'hetv.

Bentlike a bow, Kotvkse.

to Bereave, Kvpeyecic'etv.

Berry, Nak-en-lokce.

Berry, (small one), Sewvp'ho.

to Beseech, Pohepetv.

to Be sick, Enoketv-hakes.

to $\mathrm{Be}$, (èxist), Ometv. 'vketv, aretv.

Besides, Svpvke, Tepáken, vfopke.

Beside, Atvkhvk'e.

Best, Hēretá, Hēretv-máhe.

to Bet, (lay upon). Etohkáyetv, Toh-kayetv.

Better than, Senhēre, Senherv'ke, Vhère.

to Better, (to make better,) Senhere-hayetv.

to Betray, Erwiyetv.

Betrayer, Erwiyv, Oh kerkúeckv. Between, Sete, Etenrawv, $\mathrm{T} \in \mathrm{n}$ rawv.

to be Between, Tenráwetv.

to Beware, Aketécetv. 'vketv.

to Bewail, Wahóketv.

to Bewitch, Emporhóyetv.

to Be with, Vpvketv.

to Be with child, Nvrkésetv.

Beyond, (as a river), Tvpalv.

Beyond (a place), Vsin, vsimv, palhvmke.

Bible, Nakcokv-rakko.

to Bid, Kicetv. 


\section{BID}

Bidder, Kicv.

Bier, Seten-kvwap'kv.

Big, Rakke, Rakrvke.

Bile, Lane, Lane-vwotkv.

Bilious fever, Hepétketv-lane.

Bill, Natokfun'ẉv.

Bin, Svtehkv.

to Bind, Wvnáyetv.

to Bind together, Ete-hvlētepúecetv.

Binding, Takfulwv.

Birch, (water), Akcelelas'kv.

Bird, Fuswv.

Bird, (little or young), Fuswrce. Birds (of the air), Fuswv-hvlwe. Bird's-nests, Fus-em-poknvk'v.

Birth, Héckvte.

Birth-day, Héckvte-nettv.

Biscuit, Tvklikucē.

Bishop, Erkenvkkv-sevpayv.

to Bite, Akketv, Kiketv.

to Bite, (occasionally), Akkvntut.

to Bite, v. C., Akkepúecetv.

to Bite off, Kecet'ketv.

Bites (of insects), Wenahókuceestakke.

Bites (of snakes), Cetto-estakke. Bites, (of mad-dogs), Efv-hacohakv-estakke.

Bit, (money), Nvrkv'puce.

Bitter, Homè, Homvkè.

Black, Lvste, Lvstute.

to be Black, Lvstetv, Lvstvt'etv.

Blackberries, Kvco-em-ette.

Blackberry-bush, Kvco-huerv.

Blackberry-root, Kvco-huerv-yvlunkv.

Black-bess, (a bug), Sokso.

Black-bird, Svkkélv.

Blackbird, (large), Svkkelv-rakko.

Blackboard, Toselkv-lvste.

Black-drink, Vsse-passv.

Black-elm, Tofósho.

\section{BLA}

to Blacken, Lvstec'etv, Ivstvtec' etv.

Black-fish, Rvro-lvste.

Black-gum, Helukwv-vpe.

Black-hawthorn, Selawv.

Black-jack, Secv.

Blacking, Eslvstec'ekv.

Blackish, Oklvste.

Black-oak, Lakcvpe.

Blacksmith, Cvto-pacv.

Black-man, Este-lvste.

Black-snake, Cetto-lvste.

Black-sumac, Tauwv-lvste.

Blade, Emfvs'ke.

Blade-of-grass, Pvhe-esse.

to Blame, Vtawetv, Kihocetv, Vhanetv.

Blameless, Mvtteko.

Blank-book, Nakcokv-oh-ho cec'. $\mathrm{kv}$.

Blanket, Vtcetv.

to Blaspheme, Hesaketvmese-en. hocetkv-satvhíket.

to Blaspheme, Tvklecetv.

a Blaze, (on a tree), Vcrsketv.

Blaze, Fenke, Lekvp'v.

to Blaze, Fenketv, Fenécetv. v. c.

to Blaze on, Oh-fen'ketv.

to Blaze a tree, Vcvs'ketv.

Bleached cotton, Tutkv-fulkvhvtke.

to Bleed, Cate-pvlatetv. Cate-tv hoyetv.

to Bleed, Catetv, Caten-encawetv.

Bleeding, Catec'kv.

Bleeding (of the nose), Yupocatv.

to Bless, Heren-opunáyetv. Ohmerretv.

to Bless, Oh-mekusvp'etv. Blessed, Enhēre, Enherákes.

Blessedness, Merretv.

to Blind, Tur-wv-akwvnáyetv. 


\section{BLI}

Blind, Turwv-he-ceko, Hēcv'keko.

Blinds of window, Ahaukucēsorv'nkv.

Blindfold, Turwvn-orvnayáhke.

to Blister, Tvkanécketv. Tvkánetv.

Blistered, Trkánē.

Blistering-plaster Estvkanéckv.

Blister-fly, Lētvkvnécv.

Bloated,Wvpv'ksē,iPéfkē, Pēféklē.

Blood, Catv.

Blood (issue of), Cáte-fi'hnē.

Blood-letting, Cátv-encáwetv.

Blood-spitting, Cáte-tófket.

Blood-shot, Cate-ohlv'stē.

Blood-sucker, Cátv-elókv.

Bloody, Cátvket.

Bloom, Pvkpáks.

Blossom, Pvk'prkē.

to Blossom, Pvkpv'ketv.

to Blot, Lvstécetv.

to Blot out, Vslécetv.

to Blow the nose, Résketv.

to Blow (as the horn), Pof'ketv, Bohketv.

to Blow, (as the wind), Hotáletv.

to Blow on, Oh-póf-ketv.

Blue, Holátte, Ok-holátte.

Blue, (pale), Okho-perétte.

Blue-bird, Fus-okholátte. Yvhík$\mathrm{kv}$.

Blue-grass, Pv'he-okholátte.

Blue-jay, Tv'ssē.

Blueish, Okholáttē.

Blue-vitriol, Cv'to-okholátte.

Bluff, Akvléftēe, Akléfē.

to Blunder, Sentápetv.

Blunt, Alutkē-cvtokmē.

to Blunt, (to cut blunt), Mútetv.

to Blush, V'lsetv.

Boa-constrictor, Estákwvnáyv.

Boar, Súkhv-hunv'nwv. Súkhvcúle.
$\mathrm{BOA}$

Board, Tosélkv. Totopéksē. to Boast, Ekvsv'metv.

Boat, Per'ro.

Boatnien, Per'ro-esfulv'lkē.

Boat-pole, Estáukv.

Bodkin. Slvpóttv-rákko.

Body, E'na.

Body, (of a tree), V'pē.

Bog, (small), Wvhélv.

Bog, Aksumóhē. Aklowáhē.

Boggy, Aklewáhē.

Boil. Lécē, Lékwē, Lekhówē.

to Boil, Móretv.

to Boil, v. c. Morécetv.

to Boil or fry, Esmorécetv.

to Boil or scald, Rv'tetv. Rvf'ketv.

Boiled or sodden, Mor'kē.

Bois-de-arc, Eto-lánē.

Bold, Fekhv'mkē.

to be Bold, Fekhv'mketv.

Boldness, Fekhv'mketv.

Bologna-sausage, Fékcē-semvtéhkē.

Bolster, Ohyápkv-cv'pkē.

Bond, Séme-tetáckv.

Bone, Fúnē.

Bone-set, Fúne-likē.

Bonnet or hat, Kap'v-tókv, Kápvtóyv.

Bony, Fúnē-tv'lkē.

Book, Nakcókv.

Book, (writing), Hotcíckv-nakcókv.

Book, (blank), Nakcókv-en-hótcisekó.

Book-case, Nakcókv-svlícetv.

Boot, Estellepíkv-cápkē. Sohtékv.

Boot, Estellepíkv-wv'nhe-hv'lwat.

Boot-tree, Sohtéhkv-svhopákv.

Borax, Cv'to-kvmóksē-ahákē.

Border, Vtékē. Mv-tv'lkv.

Borderer, Vteklíkv. 


\section{$\mathrm{BOR}$}

to Bore, Pólletv, Rolv'ketv. to be Born, Hécketv, Hecv'cketv. to Borrow, Páletv. Palépetv. Borrower, Nák-pálv.

Bosom or breast, Hókpē. Both, Vhyéyē. Hokkólv. Tepáket. Estómetis.

Bottle, Fvlásko. Tepókv.

Bottom, Opēlófv. Akpēlófv.

to Bounce back, Crtákketv.

to Bounce up, Fvtósketv.

to Bounce like a ball, v. c. Cumvtécetv.

to Bounce like a ball, Cumótetv.

to Bounce in going, Er'natásetv.

to Bound, Cumáttetv. Er'natásetv.

to Bound in going, Ematásetv. Bow, Cv'kotáksē, Etcv-kotáksē.

to Bow, Neráttetv. Potóketv.

to Bow (the head), Nekátetv.

to Bow (the head to the ground), Cumúkletv. Cumulcv'ketv.

Bowed himself down, Potókvtes. Bowels, Env'rkē, Nv'rkē. Nv'rkēlowv'cke.

Bowl, Sésketv-rákko. Palv'knakúcē.

Bowlegged, Kvwéklē. Kayv'klē. Box, Aháwv. Toháwv. ToháhwV.

to Box, Py'fketv. Pvfkv'ketv.

Boy, Cepánē.

Boy, (little), Cepánusē.

Boy-ish, Emrnétticet.

Boys, Cepanv'ke.

to Brace, or strain himself, Eyekcícetv.

Brace and bits, Espólkv.

Brackish, Tok'fe.

to Brag, Ekvsv'metv. Ekvsvmv'ketv.

to Braid, Tvr'ketv. Tvrkv'ketv. Brain, Ekv'lpē. Kr'lpe.
BRA

Bran, Tv'le-es'sē.

Branch, Elv'cē. Lv'cē.

Branch or brook, Ué-fvkucē, Hvtcuc'ē. Akvcē.

to Brand or mark, Akerkuécetv. Encóyetv.

Brand-goose, Sasv'kwv.

Branded or written, Cókē.

Branding-iron, Sén-cókv.

Brandy, (any liquor), Uehómē.

Brant or brand-goose. Sasv'kwv. Brass, Cv'to-lánē.

Brass-cock, Cvto-lánē-svcv'nkv.

Brass-kettle, Cárkvslánē.

a Brave, Trstvnv'kè.

Brave, Penkv'lkv-sekó. Fekhúnetv.

Brawler, Tvklécv.

to Bray, Píhketv.

Bread, Tvklikè.

Bread, (light), Tvklíkē-pákko.

Bread, (baked in ashes), $\mathrm{TV}$ hopélkè.

Bread-dish, Tvklíkē-palv'knv.

to Break, (as vessels), Tvkócetv.

Trkolícetv.

to Break, Kv'cetv. Tekv'cetv.

to Break-asunder, Tekáletv.

to Break-down, Tekáyetv.

to Break-loose, Corv'ketv.

to Break off from, Akv'cetv.

to Break off a piece, Kv'letv. Kvlkáyetv

to Break out a bit, Kvláksetv.

tu Break through, Es-oh-céyetv.

Breast, Hókpè.

Breast-pin, Satēhórkv-lanē. Hókpè-svlíkē.

Breath, Hesáketv.

to Breathe, Hesáketv.

Brethren, Etecákkvtē.

Briar, Kv'co.

Brick, Fákkē-nórkv.

Brick-maker, Fákkē-nórkv-háyv. 


\section{BRI:}

to Bribe, Naórketv-emvnícetv.

Bride, Hóktē-epahóyvranet.

Bride-groom, Hóktē-epáyvránat.

Bridge, (foot log), Fénv.

Bridge, (or bed,) Aktópv.

Bridle, Cuksákv.

to Bridle, Cuksakúecetv.

Bridle-bits, Cuksákv.

Bridle-rein, Cuksákv-fv'kv.

Bright, Hólocē. Hiyakv'kusē.

Brim, Tv'lowv. Cuf-tv'lowv.

Brimstone, Tvhótvplánē.

Brindle, Ketkéwè.

to Bring, Sv'tetv. Svthóyetv. Sáwetv.

to Bri g, Svlv'ketv. Svlahóketv. Esyícetv.

to Bring back, Rasfúlketv. Rasfulhóketv. Rasfúllécetv.

to Bring forth young, Heckúecetv. Heckakúecetv. Sícetv.

to Bring from, Ras-v'tetv, Asvtetv. Rasáwetv.

to Bring home, Yèlícetv.

to Bring out, Asóssetv. Aswólkētv. Asossv'ketv.

to Bring to him, Sem-vláketv. Sem-vlakhóketv. Sen-yícetv.

to Bring to me, Svm-vláketv. Svm-vlakhóketv. Svn-yícetv.

to Bring it for him, Re-résetv. Resémetv. Res-emécetv.

to Bring up, Rakúecetv. Asv'tetv.

Brisket, Hókpv-cv'nkv.

Bristles, Era-settékv. Era-éssē.

British, Mekvlēsv'lkē.

British oil, Uefópkv-nehá.

Brittle, Tvrákē.

Broach, Setēhérkv.

Broad, Táphē. Táptvhē. Táphetón.

to be Broad, Táphetv.

\section{$\mathrm{BRO}$}

Broad-ax, Pucus-tvléksē.

Broad-cloth, Vcetv-hērv.

Brogan, Estelepíkv-wv'nhé.

to Broil, Hotópetv.

Broken, Kv'lkē. Trkv'ckē.

to be Broken, Kv'cketv.

to be Broken down. Emún-tv'l-

ketv. Emún-tvlhóketv.

Broken a piece out, Krláksē. Kvlv'skvkē.

Brooch, Hókpē-svlíkv.

Brook, Hv'tcucē.

Broom, Espáskv.

Broom-handle, Espáskv-em-vpē. Broom-grass, Páhcē.

Brother, (older of man) Rv'hv.

Brother, (younger of man) Cúsē.

Brother, (woman's) Cer'wv.

Brother or sister by a woman, (younger) Cúsē.

Brothers-younger, Cvcusv'lkē.

Brothers, Tecákkat, or, Tecak' kvte. Tecakkéyvtē.

Brown, Okláne-ómē.

Brows, Wénhv.

to Bruise, Tonv'fetv. Rófetv.

to Bruise, v. c. Oklustícetv. Oklúslutícetv.

Bruised, Tonv'fkē, Rófkē.

to Brush off dirt, En-tvs-áyetv.

Brush, Anv'ttv. Vfóswv.

Buck, Eco-hunv'nwv.

Bucket, Uē-escaúkv.

Buck-eye, V'lv.

Buckle, Semvlíkē.

to Buckle, Semvlícetv. Setehóretv.

Buck-skin, Cússe-lánē.

Buck-skin-string, Cússe-sélkv.

Bud, Pvkpvkē, Okórē.

to Bud, Okóretv, Okorv'ketv.

Pvkpv'ketv.

Buff, Oklánē.

Buffalo, Yvnv'sv. 


\section{BUF}

Buffalo-fish, Rvr'o-lv'stē.

Buffalo-meat, Yvnv'sv-vpéswv.

to Buffet, Nv'fketv. Nvfkv'ketv. Bug, Sok'tv. Soksv.

Bug, (pumpkin) Estahókcv.

Bug, (bed) Estákkv. Fstē-yókpv.

to Build on, Oh-háyetv.

to Build, Háyetv. Ma-herícetv, Etóhtáretv.

Builder, Tohtárv, Tohtav'lkē.

Buildings, Etohtv'rken.

Bull, Wakv-cúlē. Wakv-hunv'nwV.

Bull-bat, Tokpélkv.

Bull-dog, Éfv-rákko.

Bullet, Rè.

Bullet-moulds, Rē-acv'nkv.

Bull-frog, Apvtv'nv.

Bull-tongue, (plough) Cvpiyéckvcápkucē.

Bumps, Kopohúsē.

Bunch, Ess-pvkv'ckē, Vpókhē.

Bundle or budget, Sápokv.

Burden, Hotos'kv, Sápokv.

Burdened, Sápokè.

to be Burdened, Honhóyetv.

Burial, Hopélkv. Sápokv.

Burial-place, Estē-hopélkv.

Buried, Hopélkē.

Burn, Nékrē.

to Burn, Nókretv, Rvkuécetv.

to Burn, v. c. Nekrícetv.

to Burn one's self, E-nekrícetv.

to Burn, woods or prairie, Hopotécetv.

Burned, Nekrícē.

to be Burned, Nókretv, norécetv. Burns, Nekrícē.

to Burst out, Tvkócetv.

to Bury, Hopéletv, hopélketv.

to go to Bury, Cv-hopéletv.

Bush, Afóswv, Afóswucē.

Bushel, Svker'kv-hv'mken.

Bushy, Wvsóktē. Yv-kóklē. Yvhéklē.

\section{BUS}

to be Bushy, Yvhékletv.

Business-domestic, Nak-óckv.

Business-political, Nakafv'stetv.

Nak-celákv.

to be Busy, Nak-ócetv.

But, (or turned at edge), Penútkē.

But, Mómis, Momísem.

Butcher, Elécv.

to Butcher, Elc'cetv. Lécetv.

Butchered, Lataréskv. Latárē.

Butt, of a gun, Yupvlikv.

to Butt, Ekv-es-ráhetv.

Butter, Wákv-pes'se-nehá, Nehá. Butter-bean, Tvláko-rákko.

Butter fly, Tvffolupv.

Butter-milk, Wakv-pésse-neháopúswv.

Button, Semalúmhv. Malumhv. to Button, Sete-hor' etv. Ma-lumhícetv.

Button-bush, Sakcómetv.

Button-hole, Semalúmhv-vhaúkē. Button-snakeroot, Pas'sv.

to Buy with, Res-nésetv.

to Buy, Nésetv, Nesv'ketv, Nésketv.

Buyer, Es-nésv, Snésv.

to Buzz, Renétket:, Hemomv'ketv.

Buzzard, Súlē.

By, Píket, Ete-hóyvnēn.

By and By, Hvtetófv, Hofúnof.

By, Ahoyánē.

By or through, Tehoyánē.

By means of, Tēhóyvnēn. Etēhóyvnēn.

By no means, Mónko-táyusen. Estómaten.

By them, Vnákvn.

By the way side, Nénē-témpē.

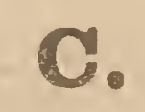

Cabbage, Essētápho. 


\section{CAK}

Cake, Trklíkē-cv'mpv。

Cage, Fus'wv-hútē.

Calabash, Fépē.

Calamus, Lvlúnkv-fv'mpē.

to Calculate, Eskerkuécetv. Ahonkv'tetv.

Calf, Wákucēe

Calf-of-the-leg, Éllen-pákkv.

Calico, Trskócv.

to Calk or stop a leak, Mvthóttetv.

Call, Huéhkv, Huéhkusē.

to Call, Huéhketv, Hohíketv.

to Call to or on, Oh húehketv.

to Call together, Nakvftécetv.

Calling, Húehkē.

Calm, (quiet) Márvpánkusē. Cryáyvkē.

Calm, Lekúthē.

to Calm, v. c. Cryayícetv. Cvyáayvkuécetv.

to be Calm, Marvpr'tketv.

Calomel, Heles-hv'tkē.

to Calúmniate, Oh-láksetv.

to Calve, Sícetv.

Camel, Rv'tce-kúphē, Yúpo-luwáke.

to Camp, Hvpo-háyetv.

Camp, Estē-hv'po.

Camphor, Kvnókkē-hēléswv.

Can, Acv'nkv.

Canaanites, Kenanv'lkē.

Canal, Ue-en nénē.

to Cancel, Vslécetv.

Cancer, Lékwē-pápv.

Candid, Mehénwetv.

Candle, Kúlkē.

Candle-moulds, Kúlkē-acv'nkv.

Candle-stand, Kúlkē-oh-húerv.

Candle-stick, Kúlkē-svhúera.

Candle-wick, Kúlkē-eshákv.

Candy, Vsókulv-nórv.

Cane, Kóha. Ráwv.

to Cane, Rokáfetv.

\section{CAN}

Cane-break, Kóha-v'lkv.

Canister, Svtéhkv.

Cannon, Tvpóckv-rákko。

Canoe, Pérro. Perrocē.

to Canter, Nvsvn-áyetv.

Cap, Kátvpókv. Kápvtókv。

Cape, Enóckv. Enócetv.

to Capsize, Ak-rvkpv'letv.

Captain, Kapetv'nè, Pvkácv.

to Capture, Sviv'fkúecetv.

to Card, Lésetv.

Cards, Naǩkcókv-tv pékse.

Cards, (for playing) Nakcók Sv'khopv'nkv.

Cards, (for spinning) Esléskv。

Care, Vcayéckv.

Careful. Aherícē. Herícē.

Carpenter, Cúko-háyv.

Carrier, Es-áyv.

to Carry, Sayetv, Svhoyetv. Svpeyetv.

to make Carry, Sayēcícetv.

to Carry about, Esáretv, Eswit。 v'ketv, Esfúlletv. Fulhóyetv.

to Carry down, Rákhvtv'pketv.

to Carry for me, Svm-áyety, Svm-vhóyetv, Svm-vpéyetv.

to Carry on the back, Acókáyetv, etc.

to make Carry on the back, Acók-ayícetv.

to Carry on the shoulder, Karónetv.

to Carry to, Res-áretv, Res-vhó。 yetv, etc.

to Carry on, Oh-crnécetv.

to Carry out, Sóssetv.

to Carry with, Sáyetv, Es-áyetv, etc.

Cart, Escv'la, Escvléckv. Cart-body, Escvléckv-pérro.

Cart-tongue, Escv léckv-tuláswv. Cart-wheel, Escvléckv-en-cv'lv. to Carve, Wocótetv. 


\section{CAR}

Cascade, Ue-oh-látkv.

to be in Case, Húeretv, Sehoketv, etc.

to Cast away, Awíketv, Apvlv'tet $v$.

to Cast before, Ehómv-apvlv'tety.

to Cast behind, Yúpv-apvlv'tetv.

to Cast down, Atv'k-wíketv.

to Cast down, Atv'kpvlátety. Sekáfetv.

to Cast down, Akhvtápketv.

to Cast down from, Ra-tv'kwiketr.

to Cast in, Cepíketv, Vpayv'ketv.

to Cast into, Trkwíketv. Akwíketv.

to Cast into, Rvpíketv. Ahíketv.

to Cast out, Sossícetv. Apvlv'tetv. Wulhúecetv. Rētv'ketv.

to Cast over, Palhv'mkv-awíketv .

to Cast under, Ellécv-awíketv.

Castor-oil, Hèlés-nehá.

to Castrate, Tehícetv.

to be Castrated, Téhetv.

Castrated, 'Tého.

Cat, Pósē. Kátē.

Catamount, $\mathrm{Kv}^{\prime}$ wákucē.

Cataract, Ue-oh-látkv-rákko.

Catarrh, O-hóketv.

to Catch, Ess'etv, Hvlátetv. Es-, áhketv.

in Catch fish, Aswíketv. Akwíketv.

Catching, Tvhtv'lkē-Tvhtvlécē.

Catechism, Nakcókv-setempóhetv.

Caterpillar, Towésēlókv . puérko.

Catfish, Kálfo, Okyv'nwv.

Catfish, Pvtikso.

Cathartic, Es-hóyvnéckv.
CAT

Cattle, Wákv. Wakv'lkē.

to be Caught, Atvkkétv.

to Cause, Omécícetv. Púecetv.

Cause, Es-vráhkv.

Causative, Omēcícē.

Causeless, Nak-omēcícē-séko。

Caution, Afekcákhetv.

to be Cautious, Encáketv.

Cautious, Encákē.

Cautious, Afekcákhē.

Cave, Akréfē.

Cave, Kvn-haúkē. Akrolvkē.

to Cease, Fukhúnetv, Wiketv. Ensehoketv.

to Cease, v. c. Wicécetv.

Cedar, Vcénv.

to Cede, Estémetv.

Cellar, Kvnsúfkē. Akhaúkē.

Cemetery, Este hopélkv.

Cent, Cvtokvnv'p-vhakē.

Centipede, Estē-táckv.

Centipede, Ellē-súlkv, Ellēcúkpē。

Centre, Nvrkv'pv.

Centurion, Kapetv'nē.

Century, Orólopē-cúkpē-hv'mken.

Certain, Fv'tcvt.

Certainly, Mehénwv. Wehénwv。 Chaff, Tv'le-es'sē.

Chagrin, Eles'ketv.

Chain, Cvto-telácv. Cvto-tetv'kkákv.

Chain hook, Cv'to-telácy-encvfokúnhē.

Chain-link, Cvto-tetv'k-kákv.

Chain-ring, Cv to-pvlókse.

to Chain, Cv'to-tetv'kkákv-wvnáyetv.

Chair, Ohliketv.

Chair-bottom, Ohlíketv.

Chair-leg, Ohlíketv-ellē.

Chalk, Es-hotcíckv-hv'tkē.

Chalk-line, Hv'tkē-estépketv .

to Challenge, Tenrv'petv. 


\section{CHA}

Chamber, Cúkocē, N N thófv .

Chamber-pot, Natv'1kv.

Chamber-stuirs, Cukocé-acémketv.

Chameleon or lizard, Táksapúl$\mathrm{kv}$.

to Champ, Yácáketv.

Change, Elíckvn.

to Change, Eticetv.

to Change, Tepoyósēcícetv.

to Ch ınge, Maráhkv-háyetv. Marákkúecety.

Channel, Uefih'nē, or enfih'nēe.

Chapel, Mekusv'pkv-cúko.

Chaplain, Erkenv'kkv.

Chapter, Setékvpv'kē.

wárkē. Setentv'ckē.

Chaicoal, Toráwr.

to Charge, Ahórícetv, Rvhécetv. Charger, (of gun) Svker'kv .

Charitable, Hērómē, Hēromv'kēe

Charity, Hērómkv, Vnokéckv.

a Charm, Tvhv'ketv.

to Charm, (please) Emvlostícetv.

to Charm, (bewitch) Por'rety.

to be Charmed, Emvlóstetv.

Charmer, Por'rv.

a Chase, Aséckv, Faká.

to Chase, Asécetv, As'setv.

Chasm, Cv'to-tenráwv.

Chaste (pure) Hvsv'tkē, hvsvtkv'ke.

Chaste, Efvtcécē, Efvtcēcv'kē.

to Chasten, Es'temerícetv.

Chastisement, Es'emeri'ckv.

Chastity, Sērak'ketv.

Cheap, Vcákeko.

to Cheat, Svlásetv.

Checkered, Tukórē, Sápsawē.

Cheek, Yvnáwv.

Cheek-bone, Yvnáwv-fúne.

to Cheer, Marvpr'tetv.

Cheese, Wakv-péssē-tvklíkē.

to Cherish, Vcáyécetv.

\section{CHE}

Cherry, Tofv'mpe.

Cherry-tree, Tofv'mpē-v'pē.

Cherry-tree (wild) Tofv'mpē seminólē.

Chest, (breast) Hok'pē.

Chest, (box) Vháuwv. Tohaháwy.

Chestnut, Otowóskē. Oto.

Chestnut-tree, Oto-v'p $\overline{\mathrm{e}}_{\text {。 }}$

to Chew, 'Tóklínetv. Yvcáketv. Cukpíketv.

to Chew, (carefully) Atóklomáketv.

Chicken, Totolósē.

Chicken-pox, Fotv'kletv.

Chicken-snake, Apiyákv.

to Chide, Vnrv'petv.

Chief, Mekko. Sémē-vpáyv.

Chigger, Wásko.

Child, Hopúewv. Estucē.

Child-like, Hokosē.

Children, Hopúetákè. Custakè. to be with Child, Envrkésetv.

to Chill, Etkólet. Etkolécetv.

Chills, Etkólkv.

Chimaey, Tótkv-hútē.

Chin, Notv'khv。

Chinch, Estákkv。

Chinquepin, Takafúnwv.

a Chip, Tocv'sketv.

to Chip, $\mathrm{Kv}^{\prime}$ letv.

Chisel, Etó-eskórkv. Sóhtáketv. Es-kófkv.

to Chisel, Enkóretv.

Choice, Enhópokē.

to Choke, Nokcepéletv.

to be Choked, Nokliketv.

Cholera, Enóketv-enyékcē.

Cholera-Morbus, Enóketv-enyékcé.

to Choose, Svthóketv. Ensv'tketv. En-hopóketv. En-hopóyetv.

to Chop, Cv'sketv. 


\section{$\mathrm{CHO}$}

Chopper, Eto.cv'skv.

Christ, Klist, Tèyósē.

Christian, Mekusápy.

Christians, Mekusapv'lkē.

Christians, Klist-vlke.

Christmas, Nettv•cáko-rákko。

Chrysalis, Púeyvfékcv-ensúkcv.

Chub, R.v'ro-palóksē.

Church-member. Mekusápv.

Church Mekus»'pkv-cúko.

Church-yard, Mekusv'pkv-cúkoféttv.

Churn, Eskofókṽ.

to Churn, Kofóyetv.

Churn-dasher, Eskofókv-mv'pē.

Churn-lid, Eskofókv-ohrv'nkv.

Churned, Kofókè.

Cider, Uetóksē.

to Cipher, Vhónkv'tkv-háyetv.

Cion, Ahóntosat.

Circular, Polóksē.

to Circumcise, Afulotē-tv'cetv. Kètetv.

Circumcision, Afu-lótkē-tv'ckvn. Cistern, Uekíwv. Uéwv-húte. Enfiyátv. Ue-enkórkv.

Citizen, Metvlhv'mkē. Trsēkia. Citizens, Tvlofv'lkēe Tvlófvtehk $\bar{v}^{\prime} l k \bar{e}$.

City, Tvlófv-rak'ko.

Civil, Yvmv'sē.

to Claim, Pucásetv.

Clam, Folvh'pv.

Clamp, Svwēkēlkv。

Clan, Mvlíketv.

Clan, (war) Kēpáyv.

to Clap, Setetépketv.

to Clap, (the hands together) Sëtepokícetv̀

Class, Mētohkv'llketv.

Claw, Ellen-kosósvwv.

Clay, Fak'kē.

Clean, Hvsv'tkē. Hvsathákuse. to be Clean, Hvsv'tketv.
CLE

to Cleanse, Hr'svtécetv.

Clear, Hiyáyv'kusē.

Cleft, Eté-yakyvpē.

Clergyman, Er'kenv'kkv.

Clerk, Esnésv. Hotcic'v.

Clever, Hēret.

Clevis, and pin, Cvto-kúnhusat.

Cliff, Hvlwē-yoh'wēyeyat.

to Climb with, Sóhcēmécetv.

to make Climb, Acēmécetv.

to Climb, Acémketv, Cémketv。

to Climb up, Av'cémketv.

to Climb on, Oh-cémketv.

to Cling with both hands and feet, Akolówetv.

to Cling with both hands, Kóló. wetv.

to Cling to, Ayókcetv. Ayokcv'ketv.

to Clip, Kēlécetv.

Cloak, Kápv-rak'ko.

Clock, Hv'sē-vker'kv-rak'ko.

to Clog, Alok'petv, Alokpic'etv.

Close together, Tepóktē.

to Close, (sin:) Ak'hóttetv.

to Close, (pl.) Ak-hottv'ketv.

Closet, Ar'vnákv. Cukócē. Nvthófucē.

Cloth, Nak-vléskv.

to Clothe, v. c. Vtcécetv. Vtcē.. c ' 'ketv.

to be Clothed, Vtc'etv. Vtcv'ketv.

Clothed, Vic'vkē.

Clothes, Nak.vtc'etv。 Vtc'etv.

Clothes-brush, Kápv-espáskv .

Clothes-line, Nak-oh-enhófketv$\mathrm{fv}^{\prime} \mathrm{kv}$.

to Cloud up, Aholócetv.

a Cloud, Ahólocē.

a Club, (any thing thrown) Svfv'1$\mathrm{kv}$.

to Cluck, Toktóketv.

Coach, Es'-cvléck v-pv'fnv. 


\section{$\mathrm{COA}$}

Coach-whip-snake, Hvtkéketvtelv'kv.

Coal, Cv'to-knorkv. Toráwv. Coal-mine, Toráwv-enkor'kv. Coals (of fire), Toráwv.

Coarse, Cvcor'kēwet. Pacálē. Coast, Ue-vfópkē. Vfópkē. Asén$\mathrm{kv}$.

Coat, Kápv.

Cobb, Talv'pē.

to Cobble, Malúm-hícetv.

Cock, Totolósë-hunv'nwv.

Cock-crowing, Totolósē-hákvcuks.

to Cock a gun, Enhuerícetv.

Cock-eyed, Cvkéksē.

Cocked up, Cvméksē.

to Cock up, Crméksetv.

Cockleburr, Kvcóklófkv.

Cock-roach, Naor'kucē. Cvháhtv.

Cock-spur, Oklvfúnv.

Cocoon, Puyvfékcv-ensúkcv.

Coffee, Káfé.

Coffee-mill, Káfē-sémfulótkv.

Coffee-nvt, Kvtoh'wv.

Coffee pot, Kafe-acvn'kv .

Coffee-sack, Kafe-en-súkcv.

Coffin, Tohah'vwv.

Cogitation, Vkeríckv.

to Coil, Tulpóketv.

Cólander, Sen-culéckv.

a Cold, Yukséhnetv.

to take Cold, Yukséhnetv.

to be Cold, Kvsv'ppetv.

Cold, Kvsvp'pē. Kvsténkv.

Cold (very) Kvsv'ppetá.

Cold-bath, Kvsvp'pë-aklópetv.

Cold-chisel, Cv'to-svkóretv.

Cold-flour, Apv'skè.

Colds, Yukséhnē.

Cold-water, Ué-kvsvp'pē.

Colic, Wapv'ksetv.

Collar, Oh-enóckv.
COL

Collar-bonē, Enfv'cv.

Collar, (for horse) Rak'ko-semenóckv.

Colonel, Háco. Pvkácv.

Colt, Corak'kucē.

Column, Séten-tvkhákvv.

Comb, Eskáskv. Espókv.

Comb, (side) Svcv'kcvhéckv.

Comb, (of a cock) Kosvtáknv.

Comb, (fine) Ëckv-spókv.

Combed, Káskē.

to Come, V'tetv, Vthóyetv. V'wetv.

to Come back, Alv'ketv. Vlahóyetv. Yícetv.

to Come back, Afúlketv. Afulhóketv. Ralv'ketv. Afulécetv.

to Come across, Mafvtcécetv.

to Come after, Yesfúlketv. Yesfulhóketv. Yesfulécetv.

to Come along a stream, $A v^{\prime}$ fopécetv. Av'fopecvkhóketv. Avfópēcr'ketv.

to Come around, Av'fullótketv. Av'fullothóketv. Avfullotécetv.

to Come behind, Yupv-v'tetv.

to Come by, Yíyetv. Ahoyv'netv. Yvhóyetv. Rv'yetv.

to Come down, Ahvlópketv. Ahvtvphóyetv. Ahvtvpécetv. to Come down, Hvtvpécetv.

to C'ome from, Er-v'tetv, Ervthóyetv, Ér-v'wetv.

to Come from, Av'tetv.

to Come in, Ascéyetv, Ayecéyetv.

to Come into, Acéyetv, Acukolv'ketv.

to Come into, Er'ecéyetv.

to Come near, Vnakúecetv. Vwo. licetv. Tempúecetv.

to Come on, Aoh-cémketv. 


\section{$\mathrm{COM}$}

to Come out, A-óssetv, Aoshóyetv, As-óssetv.

to Come out, Vwólketv.

to Come over (a river) Atíketv. Atihóketv. Atiyécetv.

to Come over from, Ra-óssetv. Aóh-wáletv.

to Come over, (as a fence) Atwvlv'pketv.

to Come there, Er-óretv.

to Come through, Rvpóttetv.

to Come to from, Aoh-v'tetv. Aoh-vthóyetv. Aóh-v'wetv.

to Come up, Acémketv.

to Come and drink, Yésketv.

to Come and tell him, Ye-monáyetv.

Come here, Yv'mvn áhtes.

to Come and drive away, Yvtóhketv.

a Comer, Atv. Vlákv .

Coming; Walv pécē.

to Comfort, Márvpáttetv.

Comforter, Emáhlvpátv.

to be Comforted, Marvpv'tketv.

Comfort your hearts, Marv-pvtetícvks.

to Command, Mvcah'netv.

Commander, Pvkácv.

Commandment, Vhákv.

to Commence from, Vtecícetv.

to Commence, Vlicécetv.

to Commend, Akvsv'metv.

Common, Tv'lemè.

Companion, Hor-kásv, Pv'lsē.

to Compare, (liken) Es-ahopáketv.

Compasses, Essátetv.

Compassion, Merkv. Merretv.

to Compel, Oh-yek-cícetv.

to Complete, Esyuk-póyetv.

to Compute, Ahonkv'tkv.

to Conceive, (be with child) Nvrkésetv.

\section{$\mathrm{CON}$}

Concerning, Kic'kv. Oh-fvt'cuton. to Condemn, Ehaperkúecetv. Ohfvtcēcetv.

Condemnation, Oh-fvtcécetv .

to Conduct, Se-vpáyetv.

to Confess, Eóh-kerkuécetv.

Confession, E-óhkerkuéckv.

Confession of faith, Akvsv'mkvóce-ēóh-kerkuéckr.

Confidence, Afēkrákketv.

Confusion, Tēhónkv.

to Conjure, Porretv. Pohyvk'etv. Conjurer, Pórrv.

to Connect, Apvk'etv.

to Conquer, Muntáletv.

Conquorer, Muntálv.

Conscience, Kerríckv.

to Consider, Vkerricetv.

to Console, Em-áhlvpvt'etv.

Constable, Estē-wv náyv.

to Constrain, Atehkepuécetv.

to Construct, Háyetv.

to Consult, Opunayécetv .

to Consult together, Etém punahóyetv.

to Consume, Nekrícetv.

Consumption, Ohóketv-kvr'pē.

to Contemn, En-homécetv.

to Contend, Opunv'kv-temvlécetv.

Contention, Eten-rv'pkv.

to Contradict, Helaksécetv.

Contrary, Vnrvpèt.

Contrary part, Vpalhv'mken.

to Converse, Tempunahóyetv.

Converted, Fulótkē.

Conversion, Efékē-mvráhkv-háketv.

to be Converted, Em-aráhketv.

to Convey, Sáyetv, Svhóyetv, Svpéyetv.

Convúlsion, Sókhē, Sok'hetv.

Cony, Cúfē.

to Cook, v. c. Nori-cetv. 


\section{$\mathrm{COO}$}

a Cook, Hómpetv-hayv. Norícv. to Cook, Hompétv-háyetv. Nóretv.

to Cool, Akvsvppuécetv.

Cool, Akvsv'ppē.

Copper, Cvto-lánē.

Copperas, Cvto-okholátte.

Copper-color, Lánē_ómē.

Copper-head-snake, Tokréskv.

Copper-mine, Toráwv-en-kor'kv.

Copy, Hotcíckv-svhopákv.

to Copy, Cóyetr.

Cord, Fv'kv. Eswvnáyetv.

Cork, Sen-cekkótkv. Eto-tvkwē.

Cork-screw, Sen-cekkótkv-sossícetv.

Corn, V'cē.

Corn-cob, Tálvpē.

Corner, Kvnáwv, Akúlhat.

Corn-meal, Vcē-enfulótkv.

Corn-mill, Vcē-sémfulótkv.

Corn-silk, Vtóklopē.

Corpse, Ena-ēlē. Estē-pvsátkv.

to Correct, Fvtcécetv.

to Corrupt, Ahopánetv.

Cottage, Cúkocé.

Cotton, Tótkv-fúlkv.

Cotton-cloth, Tv'rkv.

Cotton-wood, Tartv'hkv.

Cotton-gin. Totkv-fúlkv-semáckr.

Cough, Ohóketv.

to Cough, Ohóketv.

Coulter, Svcrpíyeckv-sláfkv.

Council, Nvkáftetv, Tekuéketv.

to Counsel, Tekuéketv.

Council-house, Nakv'ftetv-cúko.

Counsellors, Tekúekv'lkē.

to Count, Ahonkv'tetv.

Countenance, Torófv, Héckv.

Counter, Oh-sátkv. Sóh-sátkv.

Country, Tv'lwv.

Courage, Fēk-hv'mkē.

Cove or Cave, Ekvn-háukē.

Covenant, Setemfv'tcetv.

\section{$\mathrm{COV}$}

to Covenant, Setemfv'tcetv.

Cover, Ohrv'nkv.

to Cuver, Ohpvtuécetv. Ohrv'nketv.

to Cover, Ohránetv.

to Cover the head, Kápv-tóyetv. Covering, Oh-pvtákv. Ohrv'nkv. to Covet, Holv'cetv. Aleskv'petv. Covetousness, Holúckv. Aleskv'pkv.

Cow, Wákv.

Cow, Wákv-hóktē.

Coward, Penkálv.

Cow-killer, Fayépv.

Cowhide, Wákv.hv'rpē.

Cowpea, Tvláko-cápko.

Cow-pen, Wákv-húte.

Cow-pox, Lécē-hákv-sentv'ckē.

Crab, Svkco.

Crab-apple-tree, Éco-em-pvkánv.

Crack, Trkóckv. Tektv'nkē.

to Crack, Par'etv. Tukócetv.

to Crack a whip, Rotakkuécetv. Rotákketv.

to Crackle, Tuktukásketv.

Crackling, Akréhkv.

Cradle, (for child) Es-hanéckv.

Cradle, (for grain) Teleko-estáckv. Teleko-eswórkv.

Crag, Vkvléftē.

Cramp, (to have) Céllē.léketv.

Crane, Watúlv.

Crane, (blue) Wáku-rakko.

Cravat, Enócetv.

Craw, Nokhómpv.

Craw-fish, Svk'co.

to Crawl, Hv'lketv.

Crazy, Háco-hákē.

to Creak, Wēhécketv.

Cream, Mvkcáukv. Wakvpessēmvknehá.

Cream-cup, Wakvpessē, vcv'nkv. to Create, Háyetv. Hocácetv. Created, Hocáckē. Háyē. 


\section{CRE}

Creation, Nak-omv'lkv-hahóyvtē. Creatures, Nákē-hocv'ckvtē.

to Credit, Ahuerícetv.

Creditor, Ahuerícv.

Creek, Hvtcē.

to Creep, Vyókpetv. Hólketv.

to Creep upon, Iókpetv, Yópketv.

Creole, Muláto.

Crete, Klēt.

Crevice, Tvkuskósē.

Cricket, Culótkv.

Crier, Es-huéhkv. Píh-kunáyv.

Crimson, Cátusē. Cántusē.

to Cripple, Curótetv.

Crippled, Curótkē. Pvlvlv'kē.

Crocodile, Hvlpv'tv.

to Crook, Kunnícetv. Pokóretv.

to be Crooked, Yvnáyeyē. Yvnáhetv.

Crooked, Kúnhē. Yvnahē. Yvnaháckē.

to Crop, (cultivate) Lolscícetv.

to Crop. (off) Tv'cetv.

the Crop, Hiyo-háket.

Crop-grass, Pv'hē-yékcv.

to Cross (anything) Tohwvlv'pketv.

to Cross (a river) Tíketv, Tehóketv. Tiyécetv. Atiketv.

a Cross, Toh'weklepkv.

Cross-eyed, Turwv'fv'len-fakotē. to Cross at angles, Tohweklépetv.

Cross-legged, Ellē-tohkáyet.

Crotch, Yak'pē.

Croup, Nok-ríyet.

Crow, Osáhwv.

to Crow, Háketv. Hahóketv.

Crow-bar, Cvto-eskopélkv.

to Crowd, Teyukúsetv.

Crowded, Tohcékfe.

Crowded, Toh-cekcéfē.

\section{CRO}

Crown, Kapvtókv-hiyáyvkē.

Crown of the head, Ekv-wvnv'pv. Fuyúckè.

to Crown, Hvwécetv, Katvpóyetv.

Crowned, Katvpuécet.

to Crucify, Tohweklepkv-svrahetv. Toh'weklépkv-vtar'-etv.

to Crucify, dual, Vtarhóyetv. Vtaretv. s.

to Crucify, Vtárketv.

Cruel, Holwayécē.

to Crumble, Wokócetv. Tufv'petv.

Crumbled, Tufv'pkē.

Crumbs, Tufv'pkucé. Wokockē. Crust, Tvklíkē-hvr'pē.

Crutch, Setēkékv.

a Cry. Hakih'ketv.

to Cry, Hakih'ketv. Hakepécetv.

to Cry for, Es hakíhketv.

to Cry out, Húehketv.

Cub, Nokosúcē.

Cubit, Estekúcē.

Cucumber, Kaukv'mpv.

Cuff, Enk'e-sumfulótkv.

to Cull, Oh-pvlécetv..

to Cultivate, Lokcícetv.

Cultivator, Svcrpiyéckv.

Cummin, $\mathrm{Kv}^{\prime}$ 'mmen.

Cunning, Emekérrē.

to be Cunning, Emvkérretv.

Cup, Sésketúcē, Hálo, Sésketv.

Cupboard, Sésketúcē-svlícetv.

Cupboard, Sesketúcē-hútē.

Cupola, Cuko-yúksv.

Cupping, Cáte-sencawepuéckv.

Cupping-glass, Catē-escáukv.

to Cure, Cvfeknícetv, Cvfekni$\mathrm{cv}^{\prime}$ ketv, Cvfencicv'ketv.

to Cure, Wicécetv.

Curls, (wooly) Pecéhē.

Curls, Fvlvlv'kē. Fuyáckē. 
CUR

Curly, Penéhē.

Current, (of water) Uefih'nē.

to Curse, Tvhíketv. Hanv'ketv.

to Curse, Hanetv. s.

Curtain, Sohrv'nkv.

Custard, Semvteh'kē.

Custom, Hofúnē-nak-afvstv'lkē.

Cut, Tv'ckè.

to Cut blunt, Mútetv.

a Cut, a gash, Lv'fkē. Lvsáfkē.

to Cut ones-self, Elv'fetv.

to Cut around, Tácet-afulotécetv.

to Cut down, Tólketv. Tóletv.

to Cut down (much), Wásketv.

to Cut in two, Tètv'cetv. Tēwarécetv.

to Cut in pieces, Tewaricetv.

to Cut round, Kétetv.

to Cut with a knife, Lv'fetv.

to Cut as grass, Tácetv, Woretv.

to Clit much, Wocótetv.

to Cut up, (as meat) Latarécetv.

to Cut off hair, Tónetv.

to Cut with the axe, Cv'sketv.

to Cut off slenderly, Lvsófketv.

to Cut off, Wáretv.

to Cut with scissors, Kótetv. ut off, Warkè.

Cuticle, Hv'rpē

utworm, Opúerkv. Opórkv.

Cypher, Ahonkv'tkv-ránetv.

Cypress, Vncénvhó.

\section{D.}

Daily, Nettv-omv'lkv.

Dale, Pvnnē.

Dam, Sentv'ckē.

to Damage, Ahopánetv.

Damp, Otóhē. Lv'cpē.

to Dam-up, U'ewv-sentv'cetv.

to Dance, Opv'netv.

Dance, Pvn'kv. Opv'nkv.

Dance-ground, Paskófv.

Dance, (woman's) Hv'ketv-pvn$\mathrm{kv}$.

\section{DAN}

Dancing-ground, Paskófv .

Dandruff, Ekv-tóskv.

Dangerous, Penkv'lkv. Ehótkē.

Danger, (to be in) Enhec'ke-tetáyetv.

to Dare, Fekhv'mkē-óh-áyetv.

to Dare, Mahërícetv.

Dark, Yomúckē.

Darkness, Yomúckē.

to Darn, (fix) Mahērícetv.

Darning-needle, 'Srapóttv-rákko.

to Daub, Alófetv. Aloflúecetv.

Daubed, Alólkē.

Daughter, (elder of a man), Echústē.

Daughter, (younger of a man) Echúswv.

Daughter, (ur son of woman) Echuswv.

Daughter-in-law, Mehiwv. Hvtésê:

Day, Nettv.

Day-break, Hvthiyv'tkē-vláks.

Day-light, Hvthiyv'tkē. Hiyvtíkē.

Day-after-to-morrow, Páksē-vsi$\mathrm{mv}$.

Day-before-yesterday, Paksv'nkē-vsiv'nkē.

Deacon, Estē-merroyv'lkē-vhèc'icv.

Dead, Prsv'tkē, Prsvtkv'kē.

Dead, or drywood, Eto-tátē.

to Deaden, a tree, Talécetv.

Deadly, Estē-lécē.

Deaf, Póheko.

Deafness, Póheko.

to Deal, Ten-yopósketv.

Dear, Vcákē.

to be Dear, Vcáketv.

Death, El'kv.

to Debate, Tém-punahóyetv.

Debater, Tém-punáyv.

Debt, Ahuérē. 


\section{DEB}

to be in Debt, Vhúeretv.

Debtor, Ahuérv.

Decapolis, Tecápoles.

Decease, Elkv.

Deceitful. Vkérrē.

Deceit, Mvkérretv. Mvkérrē.

to Deceive, Sem-ēláksetv, Ehosvkuécetv, Éhusícetv, Mvkérretv.

to be Deceived, Ehósetv.

Deceiver, Mv-kérrv. Vkérrv.

December, Rv'fo-rak'ko.

to Deck, Hérē-háyetv.

to Declare, Mehen'wēcetv.

to Declare, Asténkerkúecetv.

to Decrease, Yokópetv.

Decrease, Eshoyv'netv.

Deeds, Nak-celákv.

Deep-hole, Aksúikē.

Deep, Laúkē, Súfkē.

to be Deep, Laúketv.

to Deepen, Sufécetv.

Lauwēcécetv.

Deer, Éco.

Deer-skin, Éco-hvr'pē.

to Defame, Hocéfkv-hopánetv.

to Defeat, Emuntv'letv.

to Defend, Eematvkháketv.

to Defile, Ahopánetv.

Deformed, Pvcóksē.

to Defraud, Sem'èláksetv.

to Defy, Em-ekvsv'metv.

to Delay, Vtétetv. Fekhúnetvawecícetv.

to Delight, Menhēr'etv. Vlostícetv.

to Delight in, Vlósticv'ketv.

to Deliver up, En-wíketv.

to Deliver us, Asēpusícetv.

to Deliver, Sēp-ossícetv.

to Deliver, (release) Enfvtcv'petv. Enkvpíyecícetv.

Deliver up, Pihóketv. Sēcēpéyetv.
DEL

Dell, Lvpv'tkē.

to Delude, Ehósvkuécetv.

Deluge, Uelaúkē-rak'ko.

to Demand, Empóhetv.

Demon, Este-neklícv.

Den, Apóketvn. Hútē.

Dense, Cékfē-hēren.

Dented, Pvcóksē.

to Deny, Ehēláksetv. Tvklécetv. Helaksécetv.

to Depart, Kvpv'ketv.

to Depart from, Yoh-fullēcépetv.

Departure, Enkvpv'ketv.

to Depend, Em-enhónrety.

Depravity, Holwayéckv.

to Deride, Vpēlícetv.

to Descend, Hvtápketv.

Descendent, Róhonv'psē.

Desert, Vuráwv. Svlotohfv. Trn'. kan.

to Desert, Enkvpv'ketv.

Deserter, Súmkv.

to Deserve, Enhēckuécetv.

to Desire, Yácetv. Eyácetv. Kómetv.

Desk, Oh-hotcíckv.

Desolate, Tv'nke.

Desolation, Tvllahássē, Súmketv. to be Destitute, Vnáhetv.

to Despise, Homécetv, Vnrápetv.

Despisers, Tvklēcv'lkēe.

to Despoil, Ahopv'netv.

to Destroy, Sumēcícetv. Lēkáfetv. Súmketv.

Destroyer, Espókv. Hopv'netv.

Destruction, Sum'ketv.

Devil, Este-nekrícy. Sétvnē.

Devil's-shoe-string, Vlonéskē.

Devious, (side-wise) Fvléknē.

to Devour, Lóketv.

Dew, Séco.

Dew-berry, $K v^{\prime}$ co-hv'lkv.

Dextrous, Mvnv'ckē.

Dextrous, (very) Mvnv'cketá。 


\section{DIA}

Diarrhœa, Nvrkv'kkv.

Dicky, Yokófketv-hókpē.

to Die, Filetv, Pvsv'tketv.

to Die (as a tree) Táletv.

to Differ, Temvráhketv.

to make Differ, Etúecetv.

Differences, Mvráhrv'kkv.

Different, Mvráhkv. Cahmelíke.

Difficult. Eshēr'eko, Esshērvrónks

Diffident, Oh-fékhv'mkeko.

to Dig, Kórretv. I áuwetv.

to Dig with, Sen-kórretv.

to Dig out, Akkófetv.

Digger, Kórrv.

Dike, Ekvn-kórkv.

Diligent, Afēkcáket-hëret.

Dim, Yomúckēómē.

Dime, Nvrkv'pucē.

Dimple, Súfkè.

to Dine, Hómpetv.

Dining-room, Hómpetv-cúko.

to Dip, Akpiketv. Svkcáwetv.

to be Dipped, Aksúmketv.

Dipper, Svkcaúkv. Escáukv.

Dipper, (person who dips) Aksúmkv.

Dire, Sehonéckē.

Dirt, (earth) Fákkē.

Dirt-dobber, Natárv.

Dirty, Lēkv'cwē. Svholwákē.

to Dirty, (pollute) Aholwayécetv .

Dirty-water, Uéwv-holwákè.

to Discard, Vslécetv.

Disciple, Kérrv, Kérrepv.

Disciples, En-kèrv'lkè.

Discipline, Fvtcécetv.

to Discover, Ker'retv.

Disease, Eakv'lkv, Ena-nok'ké.

to be Diseased, Es-enok'ketv.

to Disgrace, Eleskúecetv.

Disgrace, Vlésketv.

to Dish,'v. c., Puehícetv .

Dish, Pvlv'knv-súfkat.

\section{DIS}

Dished, Púekē.

to Dislike, Em-enhēr'etv-sēko.

to Dislocate, Cvrótetv.

Dislocation, Cvrótkē.

to Dismiss, Wicécetv.

to Displace, Akuēyícetv.

to Dispute, Telaksécetv. Tēhēlaksécetv.

to Dissolve, Vlekwicetv.

Distant, Hopíyē.

Distemper, Yuksēh'netv.

to Distress, Efékē-nokkícetv.

to Disturb, Naorícetv.

Ditch, Ue-en-nénē. Ekvn-kórkv .

to Dive, Ak-cēyícetv. Aksúmketv.

Diver, Aksúmkv.

Diver-duck, (a loon) Wahkólv. to Divide in two, Yeshvtápketv. to Divide, Tekvpv'ketv. Tek. vpícetv. Tekvpáyetv.

to Divide amongst them, Vwáretv.

Divided, Tekvpv'kē.

Dividers, Tekvpayv'lkē.

Division, Sêtekvpv'kē.

Divorce, Nak-hótcē-éssetv-wíketvn.

Divorcement, Estē-wíketv. Setekvpv'ketv.

to Do, Momécetv. O'mētv.

to Do thus, Híyomécetv.

to Do good, Lopícetv. Fnlopícetv.

to Do like this, Hvmmécetvhiyómē.

to Do likewise, Matvpo-mécetv.

Doctor, Vlékcv, Helesháyv.

Doctor of Divinity, Vhákv-kérrá.

to Doctor, Vlek'ceiv.

Doctrine, Vhákv.

to Dodge, Pvcésetv. Cvnásetv. Potókketv.

Doe, Eco hóktē, Eco-étskēe. 


\section{DOE}

Doer, Vfástv.

Dog, Éfv.

Dog-wood, Atvp'ha.

Doing, Vfástē.

Dollar, Cvto-kunáwv-hv'mken.

Domestic, (cotton) Tótkv-fúlkv.

Domestic-business, Nak-óckv.

Donkey, Corak'ko-wah'kv-píhkv.

Do-not-know, Kérrvks.

Door, Vhaúkē, Háukvkē.

Door-latch, Sémvtakkákv. takkákv.

Door-Shutter, Svkhótkv.

Dose of Medicine, Hēléswv-émētv-hv'mken.

to Double, Pvkócetv, Tepvkócetv.

to Double, v. c., Tepakuécetv.

Double, Tepvkóckē.

Double-tree, Yúpv-matv'k-hákv.

to be Double-minded, Hokkolícetv.

to Doubt, Émen-hónrēmahéskotetás.

Doubtless, Mehen'wē.

Dough, Tvklíkē-hakv.

Dough-nut, Tvklíkē-cv'mpv-svkmor'kv.

Dove, Pv'cē-hówē.

Down, Ak.

Down (of fowls) Em-mok'kē.

Down in, (midst of) Aknvrkv'pv.

Down-below, Hvcátv.

Down-stream, $A^{\prime} t v$.

Down-ward, Kvncvp'pv-fv'tcv.

Drab (color) Lánē-ómē.

Draft, Cvtokunáwv-escáukv.

to Drag, Sofotécetv. Hvlátetv.

to Drag ones self, Sofótketv.

a Drag, Hvlátv.

Drain, Fíhnē.

to Drain, Fihnécetv, Aktáyetv.

Drake, Fúco-hunv'nwv.

Draughts (drinks) Es'ketv.
DRA

to Draw (with horse) Hvlátepuécetv.

to Draw up, Yocóftetv.

to Draw near, Vwolícetv.

Drawer, Tohah'wv, Svpíkv.

Drawers, Ofv-tekpíkv.

Drawing-knife, Scvláfkv. Eto* eskvláfkv.

to Draw near, Awolícetv. Vnakuécetv.

to Draw-together, Yocóftetv.

Drawn together, Yocóftē.

Drawn up, Yocóftē.

to Dread, Penkv'letv.

Dreadful, Ehútkē.

Dream, Apueckv, Pusvlkv.

to Dream, Apuécetv. Pusv'letr.

to Drench, Heléswv-eskuécetv.

to Dress, Vtc'etv. Hónnetv.

Dress, Hon'nv. Nēhéckv.

Dressed, Káskē.

Dried-apples, Svtv-rak'ko-kvr'pē.

Dried-peaches, Pvkánv-kvr'pē.

Drill, Eskor'etv.

to Drill, Pólletv. Kóretv.

Drilling, (cloth) Tótkv-fúlkvyékcē.

to Drink, v. c., Eskuécetv.

to Drink, Es'ketv, Eskv'ketv, Esiketv. Resketv.

to Drink with, Sésketv.

Drinker, Es'kv.

Drink, Es'ketv. Nak-es'ketv.

Drinks, Es'ketv-em-vrarv'kkv.

to Drive. Atóhketv.

to Drive around, Vfulóthúecetv.

to Drive away, Etv-ayecícetv.

to Drive back with, Rásentóhketv.

to make Drive in, Vtēhepúecetv.

Driver, Vtéhkv.

to Drive off, Rvtóhketv.

to Drive out, Aossícetv.

Driven-about, Vtóhkē. 


\section{DRC}

Drone, Fo-uecawv. to Droop, Púlsetv.

Droopy, Púlsē.

Drop, Cv'fkē.

to Drop, Cv'fketv, Cvfécetv.

to Drop down in, $\mathrm{Ak}^{\prime}$-cvfcícetv.

to Drop off, Curáketv.

to Drop suddenly, Merócketv.

Dropsy, Hvsáfkē-enok'ketv.

Drought, Os'kē-séko.

Drover, Atóhkv.

to Drown, Akpvsv'tetv, Akéletv. to Drown, v. c., Akēlécetv. Akpvsv'tetv.p.

Drum, Towatólkv. Tvmvmápkv.

to Drum, Trmvmápkv-náfketv.

Drum-fish, Rv'ro-cvnv'ksē.

Drunk (to get) Hácetv.

Drunk, Hácē.

Drunk, (to make) v. c., Hacécetv.

Drunk (not) Háceko.

Drunkard, Uehómv-esk̄v. Esstēhacē.

Drunken, Máhē-yv'mkē.

Drunkenness, Hácetá.

Dry, Tvrákē. Kvr'pē. Sak'pē. Kvrkápv.

to be Dry, Kvr'petv, Akv'rpetv.

to Dry, Kvrpécetv.

to Dry up, (sin.) Akárpetv.

Dry-wood, Eto-tálē.

Duck, Fúco.

to Duck, Akpíketv.

Duck's-eggs, Fúco-ēcustákē.

Dug, (a teat) Epes'sē.

Dug-out, Kófkē. Akkórkē.

Dulap, Nok-vtar'kv.

Dull, Téfnè.

to be Dull, Téfnetv.

Dumb, Punáyekot. Opunákeko.

Dumpling, Trklikē-ómē.

Dun, (color) Lánē.

\section{DUN}

Dungeon, Cuko-yékcē-máhē.

Dung-hill, Svlekwí-cetv-vtelokat.

During, Momófvn.

Dusk, Yáfkē.

Dust, Fak'kē. Ésu-mókv. Okē. Mókē.

to Dust-ones-self, Etvkpv'fketv.

to Dust, (sprinkle it) To-sáyetv.

Duty, Nak-celákv.

Dwarfish, Vpēlélē. Kéntē.

Dysentery, Nvrkv'kv-rák'ko. Nvrkv'kv-cátē.

\section{E.}

Each, Setetáyet. V'lkē, Vpákat. Each-one, Esyómat-tes.

Each-other, Etē, Éten, Etem.

Eager, Oh'-kusápē.

to be Eager, Oh-kusápetv.

Eagle, (coin) Cvtokunvp-pálat.

Eagle, (bird) Lv'mhē.

Eagle, (bald) Hvtkē-tekfv'nkv.

Ear, Hvc'ko.

Ear-ache, Hv'cko-enok'kē.

Ear of corn, V'ce entálvpē.

Ear lock, Hv'cko-pókv.

Early, Hiyv'tkē, Hv'ten.

to Earn, Epoyetv.

Ear-ring, Hv'cko-tar'kv.

Earth, Ekv'nv.

Earthen-ware, Arkv'swv.

Earthen-pot, Natv'rkv.

Earth-quake, Ekv'n-nekéyet.

Nekéyv.

to Ease, Cvyayécetv.

to "Ease une's self," Seáholv'n. etv.

Easier, Sen-yékcē-kókv.

East, Hvsóssv. Hvsóssv-fv'tcv.

Easy, Yuléhē. Yekcéko.

to Eat, Pápetv. Hómpetv.

to Eat anything dry, Kókketv.

Eatable, Papúē. 


\section{EAT}

Eater, Pápa.

Eaves, Yvnákhv'kkv.

Eclipse of the moon, Hvsē-hēréssē- tepóyet.

Eclipse of the Sun, Hvse--teyvpósketv.

an Eddy, Lekúthē.

Edge of tool, En-fv'skē.

Edge of water, Afópkē.

to Edify, Toh-tv'retv.

Editor, Cokv-tv'lemē-pucásē.

Eel, Acv'ppv.

Effeminate, Hóktē-ahákē.

Egg, Echuswv. (or son of a woman.)

Eggs, Custákē.

Eight, Cenvpáken.

Eighteen, Pálē-cenopóhkáken.

Eight-hundred,Cúkpē-cenvpáken

Eighth, Svcénvpákat.

Eighty, Pálē-cenvpáken.

Eighty-five, Pale-cenvpáken-cáhkepohkáken.

Either, Estómis.

Elbow, Ekúcē. Estē-kúcē.

Elbow-joint, Ekúcē-tohtékekv.

Elder, Vcúlē. Plespétv.

Elders, Vculv'kē. Vfastv'lkē.

Elect, Hopokátē, Hópokē. Enhopoyv'kvte.

to Elect, Estem-wíketv-háyetv. Hopoyv'ketv.

Election, Estem-wíketv-háyetv.

Elector, Estem-wíketv-háyv.

Elephant, Yúpo-luwákē.

Eleven, Pálen-hvmkvntvláken.

Eleventh, Espálē-hvmkvntvláken.

Elk, Eco-píhkv.

Elm, (red) Afósho. To-fósho.

Elm. (slippery) Lupákv.

to Elope, Sumketv.

Else, Estómis.

Elsewhere, Estómis.

to Emaciate, Rēkósketv.

\section{EMA}

Emaciated, Rēkóskē.

Embers, Ésu-híye. Toráwv.

to Embrace, O:áketv.

to Embrace him, Rem-otáketv.

Emetic, Svwótkv. Vwótkv.

Emigrant, Cunéckv.

Emigrants, Cunēckv'lkē.

to Emigrate, Cunécketv.

Emperor, Tvlwav'lkē-em-mek'ko.

to Employ, Páletv.

Employment, Mvfv'stetv. Nakcelákv.

Emptiness, Tv'nkv.

Empty, Tv'nkē. Trnkékv.

to be Empty, Trnkétv.

to Empty, Afvlécetv, Fvlécetv

to Enclose, Vkúlulúecetv.

to Encompass, Mafulótetv.

to Encourage, Mvcah'neiv.

to be Encouraged, Vyékcetv.

End, Wíketv. Yúksv. Espókē.

to make an End, Yuksícetv.

to Endure to the End, Mun'ketv.

Eyuksícetv.

Enemy, Hor'rē. Vnrápv.

to Engare, Nakē-celáyetv.

England, Mékvláse.

English, Mekvlesv'lkē.

Englishmen, Trpálv-rakkv'lkē.

English-pea, Tvlako-pakucē.

to Engrafi, Vsékketv. Vsúketv.

to Enlarge, Rakkúecetv.

Enlarged, Vrákkē.

Enlarged-spleen, Awv'nhē.

to Enlighten, Hoporénkv-émetv.

Enough, Táyē. Tetáyes, Tetás. Estvmáhen. Setetáyv'kē.

to be Enough, Táyetv. Tetáyetv.

to Enrage, Cvpakkúecetv.

to Enroll, Hocéfkv -tokv'letv.

to Enter, Céyetv, Cukoláketv. Secéyetv. 


\section{ENT}

to Enter in, Ecéyetv. Escéyetv. Róretv.

to make Enter in, Vtēhkepúecetv.

to Entice, Naorícetv. Mvkérretv.

Entrails, Fékcē.

Envious, Semvléskvpē.

Envy, Máholóckv. Aleskv'pkv. to Envy, Aleskv'petv. Maholócetv.

Epilepsy, Sókhē.

Equal, Emē-tetayécē.

to Equal, Emē-tetayécetv.

to be Equal to, Etv-pómetv.

Equally, Etetih-hv'mkusen.

to Equip. Ehopáketv.

to Erase, Vslécetv.

Erased, V'slè.

to Erec: Háyetv.

to Err, Ehósetv.

to Escape, Em-vnv'ttetv.

Eschellotes, Táfvmpúcē.

Esophagus, Sen-nokmélkv.

to Espouse, Senfv'tcelv.

to Esteem, Vlóstetv. Arakkúecetv.

Eternal, Estófis.

Eternity, Me-yúksv-sekó.

Eucharist, Hesáketvmesé-enhómpetv.

Eunuch, Éstē-tēhvkét. Tého.

to Evacuate, (unload) Tvnēcícetv.

to Evade, Afulótketv.

Evangelist, Tv'lemē-er'kenvk'kv.

Even, Tis. Tetahóyuset. Tán.

to be Even, Etahóyetv, Tetahóyetv.

Even as, Tis'em. Máhusat.

Even so, Matvpómusen.

Evening, Yáfkē.

Ever, Stófis. Emúnken.

Ever and Ever, Estófis.
EVÊOOY

Ever-green, Lánëmúnkv. Y Everlasting, Emē-yúksv-séko.

Every, V'lkē, Vpákat.

Every-one, Vtékat.

Evident, A-enkéret.

Evil, Holwákē. Holwayéck'v.

Ewe, Yvpefíkv-hóktē.

Ewer, Uéwv-svcv'nkv-rak'ko.

to Exact, Feyícetv.

to be Exact, Mvketékē.

Exactly, Mvketévks.

to Exalt, En-homah'tetv. Hvlwécetv.

Exaltation, Hvlwécetv. to Examine, Vketécetv.

Example, Erkérkv. Vháyvtvn.

to Exceed, Múntvlécetv.

Exceedingly, Táyen.

to Excel, Múntáletv.

Excellent, Múntál : tē.

Except, Múukon-ómat. Mómekonómat.

Excess, Svhérē-máhetv.

to Exchange, Setén-yopósketv.

Erchangers, Es-yopóskv'lke.

Excommunication, Oh-sícetv.

Excuse, Sēoképkv.

to Excuse, Emē-tektvnécetv.

to Execute, Svfv'stetv.

Exh zusted, Lotókkē.

to Exhibit, Hecícetv.

to Exhort, Emvcánetv. Vcáhnetv.

Exhortation, Mvcah'netv.

to Expect, Eri-nene-hécetv.

Expedient, Vmóvkēs.

to Expel, En kvpiyecícetv.

to Expire, Életv, Pvsátetv.

to Explain, Kerkuécetv.

to Extinguish, Vslécetv.

to Extol, Hvlwécetv, Akvsv'metv.

to Extort, Svpénkvlécetv.

Extortion, Svpénkvléckv. 


\section{EXT}

Extravagance, Yvmáhkv.

Extravagant, Yvmáhkē.

Eye, Tur'wv.

Eye-ball, Tur-mérkv.

Eyebrow, Tur-esse. Wénhv.

Eye-corner, Tur-hv'cē.

Eye-lashes, Túrhē.

Eye-lid, Túrwv-hv'rpē.

Eye-Medicine, 'Tur-nókkē-heléswv.

Eye-sight, Renákv.

Eye-sockets, Tur-hvp'pv.

Eye-tooth, Nútē-fv'skē.

Eye-witness, Túr-en-kérv.

Face, Turófv.

\section{$\mathbf{F}$}

Face-towel, Ste-turófv-eshvsvtéc$\mathrm{kv}$.

to Face, Hécetv.

Fact, Mehénwv.

Factory, Hákv.

Faded, Hv'twe.

to Fail, Acvkéletv.

Faint, Mahyónkusē.

to Faint, Mahyónketv.

to Faint, Lotókketv.

Fainted, Mayónkē.

Fainting, Mahyónket.

Fainty, Mah-yónkusē.

Fair, Fvt'cv-hēre.

Faith, Akvsv'mkv. Vfekrákketv.

Faithful, Herómē. Vfekrákkē. to be Farthful, Herómetv. Fall, (autumn) Rv'fo-hákē.

to Fall, Látketv, Yórketv, Latkv'ketv.

to Fall backwards, Akvcék-látketv.

To Fall behind, Yupv'k-látketv.

to Fall down, Tvklátketv.

to Fall down from, Alátketv. Atvklátketv.
FAL

to Fall (as a tree) Tóletv . Tólketv.

to Fall into, Aklátketv.

to Fall upon, Oh-látketv.

to Fall towards, Vtúlketv.

Fail of man, Estē-acekéletv.

Fallen behind, Yupvlv'tkē.

Fallen, or cut down, Tólkè.

Falling water, Uē-ohlátkē.

Falls of water, Cáhkē-oh-látkv.

False, Hēreko. Mehénweko.

False-witness, Kerkúeckv-fv'tceko.

Fame, Opunáyēcan. Opunáyetv. Oh-onv'kv.

Family, Cuko-hvmēcv'lkē. Encukotékv.

Famine, Elaúko.

Famish, Melaúketv

Famous, Akvsv'mkē. Arakkuéhucē.

Fan, Semákv. Em-máyetv. Esemwé kē.

to Fan, (as corn) Aktónetv. Wésetv, Máyetv.

Fanner, Vtéwv. Vtúewv.

Fanning-mill, Semfulótkv. Semwéskv.

Far, Hopíyē. Mim'vn.

to Farm, Ahócetv.

Farmer, Cvpófv-vtótkv.

Fast, Pv'fnē. Pvfpv'nē. Alécē. a Fast, Eláukv.

to Fast, Pósketv, E-ēla-wécetv. to Fasten, Mayekcícetv.

Fastened or linked to, Alv'cē.

to make Fast, Vlēcícetv. Vlv'cetv.

Fast-handed, Vlecícē.

Fasting, Ela-wécet.

Fat, Néha.

Father, Erke.

Father-in-law, Em-mahē.

Fatherless, Erkē-malv'lkē. 
FAT

Fathom, Stelehopákv-ēpáken.

Fatigue, Hotóskv.

to be Fatigued, Hotósetv.

Fatted, Nehacv'kvten.

to Fatten, Nehécetv.

Fatty, Néhē.

Faulty, Hēreko.

to Favor, Emvnícetv. En-hónrkv. Vlóstetv. Herómkv.

Fawn, Écocē.

to Fear not, Cēpenkáletv.

to Fear, Penkáletv. Fēk-súmketv.

Fear, Penkv'lkv.

Fearful, Sehonéckē.

Feast, Hómpetv-rak'kn.

Feather, Táfy. Es'sē.

Feather-bed, Táfv-espvtákv.

Feathered, Hótkē.

February, Hótvlē-hv'sē.

Feeble, Alv'skē.

to Feed, Hompícetv. Hompvkúecetv. Nanópetv.

Feeder, Hompícv. Nanópv.

to Feign, Aháyetv.

to Feel, Pvsáketv. Pvsahlécetv. Fellows, Vpv'lwv-tohkv'ketv.

Fell, Ohlvtíket.

to Fell, Tóletv.

Female, Hóktē.

Feminine or Females, Hoktv'kē.

Fence, Tohópkē.

to Fence, Tohópketv. Toh-tv'retv.

to Fence about, Atohopkícetv.

to Ferry, Pérro-páletv.

Ferry, Pérrotíketv.

Ferry-man, Pérro-pálv.

to Fetch, Sv'tetv.

Fever, Hepétketv.

Fever and ague, Hepétkē-etkólet.

to have Fever, Hepétketv.

Few, Nvcómvsē. Nvcómet.

\section{FIB}

to Fib, Eóketv.

Fiddle, Hayéckv. Es-hayéckv.

Field, Cvpófv.

Fierce, Sehonéckē.

Fiery, Fenkákat.

Fife, Féhpucē.

Fifteen, Palen-cáhkepohkáken.

Fifthly, Résv-cáhképat.

Fifty, Pale-cahképen.

Fig, Kè-rakko.

to Fight, Tēpóyetv.

a Fight, Tepókv.

Fighter, Tepóyv.

Fig-tree, Ke-rákko-v'pē.

File, Essókucē. Essókv.

File, (flat) Essókv-tvpéksē.

to File, Sóyetv.

to Fill, Fvcécetv, Lóyetv.

to Fill with, Svfv'cetv.

Filling, Fv cécet.

Film, Nacélkv.

Filthy, Lekúcwē, Vholwákē, Vhólwahókē.

Fin, Semákv.

Final, E-respókat.

to Find, Eshécetv.

to go and Find, Reshécetv.

to Find out, Oh-kérretv.

to Find in water, Sákhécetv.

Fine, Hērakv. Telékmē.

Finger, En'kē-wesákv.

Finger-end, En'kē-yúksv.

Finger-joints, En'kē-wesákē-tētekékv.

Finger-nail, En'kē-sv'sowv.

Finger, (fore) En'kesmérkv.

Finger-ring, Esténkē-vtéhkv.

Wesákv-pih'kv.

to be Finished, Póketv.

Finished, Pókē. Espókē.

to Finish, Res-póyetv. Yókpó yetv. Espóyetv. Póketv.

Finisher, Espókv.

to Finish, Póyetv Poyv'ketv. 


\section{FIR}

Fire, Tótkv.

to Fire (with a gun) Tvpócketv . Tvpocécetv.

to make Fire, Etécetv.

Fire-dogs, Tótkv-éfv.

Fire-pan, Tótkv-palv'knv.

Fire-place, Tot'kv-en-hútē.

Fire-works, Tótkv-setéckv.

Firm, Yékcē.

Firmament, Súta.

First, Hv'tecéskv.

First-born, Hómv-héckvite.

Fish, Rv'ro.

to Fish, Akwíyetv. Askáyetv.

to Fish, (catch) Aswíketv.

Fish-chaser, Rv'ro-ássv.

Fisherman, Akwíyv. Rv'ro-póyv.

Fishermen, Rv'ro-hopoyv'lkē.

Fish-hawk, Rv'ro-pápv. Hahcékwv.

Fish-hook, Cúfo-kúnhē.

Fishing-pole, Kun-hv'pē.

Fishing-worm, Káfvnákv.

Fissure, $\mathrm{Cv}^{\prime}$ to-téfvllv'kē.

Fist, Enkē-nokóftē.

to have Fits, Sókhētv.

Fitty, Sókhē.

Five, Cah'kēpen.

to Fix, Em-ahērícetv.

Fixed-star, Kucocúmpv-fekhúnné.

Flag, (a standard) Tv'lē-lénnv.

Flag, (water) Stēfapēcv'pē.

Flail, Escēsv'petv.

Flame, Fénkè. Lēkv'pv。

to Flame, Fénketv.

Flank, Hv'fē. Hófēe.

Flannel, Cúfē-es'sē. Yvpefíkves'sè.

Flap, Ekófkv.

a Flash, Fesáhlē.

to Flash, Fèsáhletv.

Flask, Fvlásko.

Flat, Tvpéksè.

\section{FLA}

Flat-boat, Pérro-tvpéksē.

Flat-file, Es-sókv-tvpéksē.

Flat-fish, Rv'ro-tvpéksē.

Flat-iron, Estenēpíckv.

Flats, (of earth) Ekv'n-tvpéksē.

to Flatten, Tvpeksícetv.

to Flatter, Akvsv'metv.

Flax, (thread) Vfús-yékcv.

to Flay, Torófetv.

Flea, Kv'fko.

Flecked, Lekáhē.

to Flee, s. Alétketv.

to make Flee this way, Aletēém cetv.

to Flee away, Apéfátketv.

to Flee into. Sóh-létketv.

Flesh, (meat) Vpéswv.

to Flesh (i.e. to skin) Hvsv'fketv.

Flesh-fork, Cofínyv'kpē.

Fleshy, Vpésē, Vpésmē.

Flexible, Kunhíckv-yékceko.

Flight, Pefátketv.

to Fling, Svfv'letv. Afv'lety Mvfv'letv.

Flint, Ronóto.

Flint-corn, $V^{\prime} c \bar{e}-c v l v ' t w e \overline{.}$

to Float, Okvtáfketv.

Floating, Okotáfkè.

Flock, Vtelókvtē.

to Flog, Rokáfetv.

Flood, Ue-laúkè.

to Flood, Laúketv.

Floor, Tvktópv. Topvtákv.

Floppy, Werócke.

Florid, Cátē-ómē.

Flounder-fish, Apvlpv'tkv.

Flour-root, Kúntē.

Flour, Hótskvtē-hv'tkē.

Flour, (cold) Apv'skē.

Flowers, E-ehócv. Pv'kpvkē.

Flute, Féhpv.

to Flutter, Mer-máyetv.

Flux, Nvrkv'kv-cátē. 


\section{FLY}

Fly, (big black) Róno-lv'stē.

Fly, (green) Cánv·Lánē.

Fly, (horse) Róno. Róno-lánē.

Fly, (house) Cánv.

Fly, (small) Etskv-húswv.

to Fly, Súmketv. Wáhetv.

to Fly, v. c. Trmécetv. Tv'mketv.

Flying squirrel, Wíyo.

Foam, Pv'kpvkē.

to Foam, s. Pvkpvkúe-cetv.

Fodder, Cvshvpéskē.

Foe, Hórrv. En-rápv.

Fog, Hopérē,

to Fold, Rv'korícetv.

to Fold, (clothes) Tvlpóyetv.

Foliage, Eto-es'sē.

Folks, Estv'lkē.

to Follow, Tecv'k-áyetv. s. Acv'káyetv, s. Acv'k-ahóyetv, d. Acvk-vpéyetv. p.

to Follow, Acv'k-áretv, s. Acv'kweláketv. d. Acvk-fúlletv. p.

Followers, Acv'k-fullv'lkē.

Following, Acvkáyen.

Fond, Em-enhēret.

to be Fond of, En-cakúsetv. Emenhēretv.

Food, Hómpeta.

Fool, Hoporéneko.

Foolishness, Hacoháketv.

Foot, (member of body) Élle.

Foot, (hind) Éllē-yápv.

Foot, ( 2 inches) Stéllē-vhopákv.

Foot-stool, Oh-hueríckv.

Foot, (hollow of) Ellē-yunáktv.

For, Mómet. O'k. Okv'. Omíkv.

to Force, Oh-yekcícetv.

to Forbid, Vséhetv. Sen-tv'cketv.

Forbidden, Vsẹ́hkē.

Ford, Cáhkē. Tíketv.

to Ford, Cáhke-sakhuéretv. Saktíketv. Tíketv.
FOR

Fore-fathers, Purkv'lkē-tátē.

Fore-finger, Enkes-mélkv.

Fore-foot, Elle-hómv.

Fore-head, Ékv-hómv. Wénhv.

Foreign, Tvlepórē. Hopíyatē.

Tvlēè.

Foreigner, Tvlēpórv.

Fore-noon, Fv'tcv-líkē-óreko.

Forest, Eto-ofv, Eto-v'lkē.

Fore-top, Ekv-hómv-es'sē.

Forever, Múnkvres, Múnken.

Forge, Cvto-pácetv.

to Forget, Ehósetv. Huhséketv. Hohsetv.

to Forgive, Kvpáketv.

to Forgive, Krpíyecícetv. Mer'retv.

Forgiveness, Em-mer'retv. Enkvpv'ketv.

Fork, Yv'kpē, Cvfún-yv'kpē.

Fork, (of tree) Eto-yv'kpē.

Fork, (of water) Vkácat.

to be Forked, Yvkyv'petv. Yvkpetv.

Forked, Yv'kpē.

Form, Héckv.

Fornication, Hoktárē.

Forrest, Eto-ófv. Eto-v'lkē.

Fort, Tohópkē. Hórrē-tohópkē.

Forthwith, Lvpécē.

Fortnight, Nettv-cákucē-hok'kolen.

Forty, Pálē-ósten.

Forward, Hómv.

Foul, Sv-holwákē.

Foundation, Cuko-oh-lícetv. Enlíkv.

Fountain, Uēkíwv. Fíhnēmúnkv.

Four, O'sten.

Four-footed, Élle-ostv'kusat.

Four-hundred, Cúkpē-ósten.

Fourteen, Pálē-óstohkáken.

Fourthly, Sv-óstat. 
FOU
Four-times, O'sta, Sóstan.

Fowl, Fúswv.

Fox, Cúlv.

Fracture, Tekv'ckē.

Fragments, Mahóckē. Ahóskv. to Frame-together, Etèlíketv. to Frame, Kēlehícetv.

Frankincense, Hēlúkwv.

Free, (from matter) Wénetv.

Free, (at liberty) Pucásē-sēkó.

to Free, Pucásē-séko-háyetv.

to Free, s. Recópketv.

Free, (loose) Rēcópkē.

Freeman, Pucáe-séko.

to Freeze, Cúehetv. Kvsv'ppētvlofécetv.

Frenchmen, Falvncv'lkē.

to Frequent, (some place) Afúlletv.

Fresh, (unseasoned) Tupv'ksē.

Fresh-water, Ue-kvsv'ppē-

to Fret, Efékē-nokkícetv.

Fretful, Fek-hēreko.

Friday, Flítē.

Friend, Enhéssē. Héssē.

to make Friends, Tenhéssetv.

Friendly, Yvmv'sē.

to be Friendly, Ten-yvmv'setv.

Frigid, Kvsv'p'pē. Cúehē.

to Frighten, Penkvlécetv. Fēk-

sumécetv.

Fringe, Semfópkv.

Frock, Húnnv. Setorófkv.

Frog, Kútē. Supáktv.

Frolic, Pvnkv.

From that time, Vtékat. V'tē.

From, Erv'ttetv. Kvpv'kē. Atat. Aēnkvpv'kē.

Front, Hómv.

Front-tooth, Nútē-hómv.

Frost, Hetútē.

Froth, Pv'kpvke.

Frothy, Pvkpv'kē.

Frow, Ess'elkv,

\section{FRO}

Frówer, Tósetv. Essélkv.

Frozen, (or stiff) Cuéhē, Tvkv'c. wë.

Frozen-limbs, Lv'cē-cuecóhē.

Fruit, Eto-en-lókcē. Ettē.

Fruit, (unripe) Lokceko, Konók. ucē.

Fruitful, Hiyo-haket.

Fruitless, Em-ettē-sēko. Ettēko. to Fry, Móretv, Morécetv.

to Fry, Súmorécetv, Smorécetv.

to Fry, Sv'kmorécetv.

Frying-pan, Ésmoréckucē.

Frying-pan, Sv'knoréckv.

to Fuddle, Hacécetv. Enkerkúecetv.

to Fulfill, Soh-fvcécetv. Esfác. ketv.

Full, Fv'ckē. Fvcfv'kē.

to be Full, Fv'cketv. O'retv.

to be Full of, Mvketéhketv.

to be Full of pain in body, Enanok'kē-cvpórusen.

Fully, O'rē. O'rē-hēren.

Funeral, Oh-erkenv'ketv.

Funnel, Svcv'nkv.

Fur, Es'sē-tvlékmē. Telēkmē.

Fur-hat, Kápv-tókv-telékmē.

to Furrow, En-nénē-háyetv.

Further, O'h-hvtvlákat.

Further-on, Res-hopíyusen. Rahopíye.

Future, Net'tv-ócen.

Future-state, Net'ty huéretv.

Nétt -óretv.

\section{G.}

Gadfly, Fayépv.

to Gag, Awvkvlécetv.

Gain, Lopíckv. Lopicákē.

to Gain, Epoyetv, Heckúecetv.

Gale, Hotvlē-rakko.

Galilee, Kalilè.

Gall, Hvlakcowv. 


\section{GAL}

to Gall, Rvfécetv.

Gall-bladder, Hvlákcowv-húte.

Gallon: Vkérkv-rak'ko.

to Gallop, Latláketv.

to Game, Akropv'nkv.

to Gamble, Sétem-áhkopv'netv.

Gambler, Sáhkopánv.

Gander, Sasv'kwv-hunv'nwv.

Gangrene, Lékwē-holwákat.

Gap, Tvhóp-vheríkē.

to Gape, Nucáyetv.

Garfish, Es-ápv.

Garden, Cvpófucē.

to Gargle, Koróyetv.

Garlic, Tafv'mp-hákē.

Garment, Nak-vt'cetv.

Garnish, Nehícetv. Nehēcécetv.

Garter, Stelés-wvnakv.

Garter-snake, Cet'to-lánē.

Gate, Ahaúkē. Svkhotkv.

to Gather, Vtelóketv. Atelóyetv. Nanópetv.

to Gather, (from the ground) Ayócetv.

to Gather, Mámetv.

Gay, Afv'ckus. Afv'ckē.

to Gaze, Hécetv-táyē.

Mvcrnéyetv.

to Gaze upward, Anvtv'ksetv.

Gearing, Sémē-vtótkv.

to Gear up, Semē-vtótketv.

Geese, (tame) Sasv'kwv.

Geese, (wild) Aháhwv.

a General, Suletáwv-pvkácv.

Generation, Honv'psè.

Gentiles, Tvlwav'lkē.

Gentle, Yvmv'sē.

Gentleman, Estē-hērē.

Gentleness, Yvmv'sv.

Gently, Hērícusē.

German-silver, Cárkvs-hv'tkē.

to Get, Ess'etv. Cáwetv. A'wetv.

to Get in, Céyetv. Cukolv'ketv. Sēcéyetv.

\section{GET}

to Get in Sight, Yvfv'nketv.

to Get out, Os'setv, Wólketv, Sos'setv.

to Get there, Roretv.

to Get through, Ropot'tetv, Ropothóyetv, Ropottécetv.

to Get under, Ellécv-céyetv. Cokolv'ketv. Secéyetv.

to Get up, Asv'pvlvks.

Gethsemene. Kersémenē.

Gift, Nakē-wíyetv. Émetv. Estémkv.

to be Getting late, I'afyv'ketv.

to Giggle, Yvkéknetv.

Gill, (a measure) Svker'kucē.

Gills, (of fish,) Núkcvkákv.

Gills, (of fowls) Nak-v tar'kv.

Gimlet, Espólkucē.

Ginger, Céncv.

to Gird, Sēwvnákuécetv.

to Gird one's self, Sēwrnáketv.

Girdle, Sēwvnáketv. Es-wvnáketv.

to Girdle, Sēwv náketv.

Girl, Hoktúcē.

Girls, Hoktusvkē.

Girth, Sóh-wvnákv.

to Give, Hóyetv, Hoyv'ketv .

to Give, Émetv. Eh'metv.

to Give, (as a ransom) Vráhkvwíy'etv.

to Give me from or out of, A-v'metv.

to Give us, Púmetv.

Giver, Est-émv.

Gizzard, En-cv'kvspv.

Glad, Afvc'ketv. Afv'ckē.

to Gladden, Afv cēcícetv.

Glass, Estakhéckv.

Glassy, Hólocē, Ténepē.

to Glean, Oh-apvlécetv.

Glib, Hēlv'pkē. Tenáspē.

to Glimmer, Vháyiyáketv. 


\section{GLI}

to Glisten, Holócetv.

Glistening, Lepépetv. Léppē. Globular, Nokóftē. Cēréknē. to be Globular, Nóktetv. to Glorify, Arakkuécetv.

Glory, Vrákkē. Rak'ketv. Akv sv'mkv.

Glove, Estēn'kē-hútē, Esten'kvtéhkv.

Glow-worm, Cúntv-fénkv.

Glue, Svlokpíckv. Sētelokpíckv. Kulówv.

to Glue or Paste, Svlókpetv.

Glue-pot, Sētelokpíckv-vcv'nkv .

Glut of wood, Eto-fv'skē.

Glutton, Hómpetv-vnóksē.

to Gnash, Sētetéketv.

Gnashing, Sētetēket.

Gnat, Ets'kv-húswucē.

to Gnaw at, Mv-kēláketv.

to Gnaw, Kēláketv.

to Go, A'yetv. s. Ahóyetv. Vpéyetv. p.

to make Go, Ayēcícetv.

to Go about, Ar'etv. s. Weláketv. d. Fúlletv. p.

to Go about on, Oh fúlletv.

to Go abroad, Hvmecícetv. Etēhóyánetv.

to Go across, Tíketv. Tihóketv. Yí-cetv.

to Go after, Erésetv. V'thoyetv. $V^{\prime}$ wetv.

to Go along side, Vfopécetv. Cv'ketv.

to Go along a person, Entv'kketv.

to Go around, Afullótketv. Afóklótketv.

to Go around, Ra-afullótketv. Asáyetv.

to Go astray, Ehóssetv.

to Go away, Súmketv.

to Go back, Fúlketv. Fulhóketv. Fullécetv.

\section{GO}

to Go back, v. c., Fullecícetv. Yefúlketv.

to Go backwards, Vcēkélletv. Vcékelhóyetv. Vcēkellécetv.

to Go back and forth, Toh-áretv. Toh, etc.

to Go before, Homáhtetv. Homv hótetv.

to Go by with, Yes-áyetv, etc.

to Go by, Yv'yetv. Yvhóyetv. Yvpéyetv.

to Go by, Ráyetv. E'rahóyetv. Er-vpéyetv.

to Go down, Ak-hvtv'pketv. Akhv'tvphóketv. Akhvtvpécetv. to Go fast, Pvfpv'netv.

to Go from, Er-v'tetv. Rvthóyetv. Rv'wetv.

to Go into, Céyetv. Cokolv'ketv. Secéyetv.

to Go into, Rescéyetv.

to Go into water, Sakcéyetv.

to Go down stream, Atúecetv.

to Go near, Vwolícetv. Vwolicv'ketv.

to Go out, (as a lamp) V'sletv.

to Go out, O'ssetv. Wólketv. Sóssetv.

to Go out, As-óssetv.

to Go over, Toh-welv'pketv. Toh-welvphóketv, etc.

to Go past, Er-hoyv'netv.

to Go sitting by, Vlíkē-áyetv, etc.

to Go through, Ropóttetv.

to Go to, Oh-áyetv. Oh-vhóyetv, etc.

to Go under water, Aksúmketv.

to Go up, Oh-cémketv.

to Go up stream, Arepúecetv.

to Go up with, Vpv'ketv. Acvkáyetv, etc.

Goat, Cowátv.

Goblet, Séskē-rákko. 


\section{GOD}

God, Hēsáketvmesē. Cehówv. Godliness, F'v'tcváyetv. Hēretá. Godly, F'v'tcv-áyet.

Going, Ay'et.

Going? Ayá? Ayetská?

Going about, Fúlletv, etc.

Going to be, Estómvránet.

Gold, Cvto-kunv'p-lánē.

Golden-rod, Eco-hēceko.

Gold-mine, Cvto-kunv'p-lánē-enkórkv.

Golgotha, Kalkóra.

Good, Hēres. Herákē.

to be Good, Hëretv.

to do Good, Enlopícetv.

Goodness, Hēretv.

Goods, Nák-ocē.

Goose, Sasv'kwv.

Goose, (Tailor's) Es-tenepíckvrak'ko.

Goose-berry, Hiyo-lókcv.

Gopher, Hvcētékv.

to Gore, Réfketv.

to Gorge, Lotok'kícetv.

Gosling, Sasv'kwucē.

Gospel, Punv'kv-hērv.

to Gossip, Nak-óketv.

Gourd, Efépē. Fépē.

to Gouge, Ak'sekéyetv.

Gourd-seed-corn, 'V'ce-tvlókwē.

to Govern, Oh-fv'nketv.

Governor, Oh-fv'nken.

Governor of a ship, Fiyv'tkv.

Governors, Oh-fvnkv'lkē.

Gown, Kápv.

to Grabble, Wósetv.

Grace, Hérkv. En-hónrkv.

to Graft, Vsúketv.

Grain, (yet milky) Kosóhe.

Grain, Nérkv, Tv'le.

Grand-father, Púcá.

Grand-rnother, Púse.

Grand-son or daughter, Osúswv. to Grant space, Etektvnécetv.
GRA

to Grant. E'metv.

Grape, Pv'rko.

Grape-vine, Pv'rko-fv'kv .

to Grapple, Eshopóyetv. Akyékletv.

to Grasp, Hvlátetv. Ayvkhv'm. ketv.

Grass, Pv'he.

Grass, (tall) Pvh'ce.

Grass-hopper, Tv'ffo.

Grass, (silk) Suwénv.

Grater. Esóyetv.

Grave, (serious) Ok hácekon.

a Grave, Este-hopélkv, Hopélkv. Kvnkórke.

Gravel, Cvto-crsv'kwe.

Crave-yard, Este-heríckv.

Gravy, Nehá. Oknehá.

Gray, Svpv'k-hv'tke.

Gray-eagle, Lv'mhe.

Gray-hair, (of the head) Kv-es'sehv'tke.

Gray-hound, Efv-pv'fne.

to Grease, Sen-síyetv. Sesíyetv. $\mathrm{Sv}-v$ féyetv.

Grease, Nehá, Sesíyv.

Great, Rak'ke.

Great-coat, Kápv·rak'ko.

Great-deal, Táyen,

Great-multitudes, Este-súlsoke. máhe.

Greatness, Vrákke.

Greediness, Anóksetv.

Greedy, Anókse.

to be Greedy, Vnóksetv.

Green, Láne.

Green, (pale) Hv'tuse.

Green, (like grass) Pv'he-laóme.

Green-lizzard, Hacuklepá.

Green-snake, Cett'o-láne.

Green, (unripe) Aháye. Aháyv. kè.

Green-wood, E'to-láne.

Green-briar, Kvco-láne. 


\section{GRE}

to Greet, Tempunáyetv.

Gridiron, Esotópkv.

Grief, Féke-nókke.

to Grieve. Elesecícetv.

Grievous, Ennókkice.

to Grind, Fulótetv.

to Grind to powder, Lopótetv.

Grind-stone, Cvio-fúlotkv.

to Gripe, (pain) Ennokkícetv.

Grits, Hóckvte. Nérkuce.

to Groan, Hih'ketv.

Groceries, Nak-óce-hómpetv.

Groin, Kófe.

Ground, Ekv'nv.

Ground-hog, Esko.

Ground-mole, Tv'ko.

Ground-pea, Kvn-oh-tvláko.

Ground-puppy, V'ta.

Grouped togethèr, Toh-copóksē

Grouse, Kowíkē-rákko.

Grove, E'to-es-líkat.

to Grow, (a person) Máhetv.

to Grow, (corm, etc.) Húntetv.

Growing, Húntē, Huntv'kē.

to Growl, Heh'ketv.

Growth, Húntv.

to Grub, Crpénetv.

Grub, (a root) Eto-fv'kkv.

Grubbing-hoe, Acúknv.

Grubroot, (Red-shank) Kestówv

Grub-worm, Yv'lv.

to Grudge, Encáhketv. Sémvleskv'petv.

Gruel, Vcē-enfulótkv-opúswv.

to Guard, Ahēcícetv.

Guard, Ahēcícv.

to Guess, Mvsúmketv.

Guide, Mahomáhtv. Ahēcícv. Fiyátv.

to Guide, Mahomáhtetv. Fiyv'tetv.

Guilt, E'mmvt'tē.

Guilty, E'mmvt'tē.

Guinea-hen, Kowíkē-tokórē.

\section{GUL}

Gulf, Súfkē-laúkē.

to Gull, E'mvkéretv.

Gull, (a bird) Nok-súkcv.

Gullet, Sen-nokmélkv.

Gum, (of mouth) Nútē-vpéswv.

Gum, (black) Helúk-lv'stē.

Gum, (sweet) Hēlúkwv.

Gum, (of a tree) Eto-colókcowv.

Gum-elastic-shoes, Estelēpík-sēnéphókv.

Gun, Et'sv, Tvpóckv.

Gun-lock, Svpáckv.

Gun-smith, Et'sv-háyv.

to Gut, Wénetv.

\section{H.}

[As in English.]

Habit, Scvmúnk.

Hack-berry, Kapvpóckv.

Hail, Hetúte-ner'kv.

to Hail, (call to) En-hueh'ketv .

to Hail, Hetútē-ner'kv-yorécetv.

O'skè-eshetútē.

Hair, (fur or wool) Es'sē.

Hair, (of body) E'na-es'sē. Téwv.

Hair, (of the head) Ek'v-es'se. Kísē.

Hale, (hearty) Cvféknē.

Half, Nvr-kv'pv. Ren-nvrkv'pv. Half-breed, Estē-hv'tkē-háyvv.

Half-bushel, Svker'kv-nvrkv'pv.

Half-dollar, Kvnsátkv-hokkólen.

Half-way, Nénnē-cv'ppv.

Hall, Etēhoyv'netv.

to Hallow, Hvsvtécetv. Vcayécetv.

to Halt, Cekúnnetv.

Halter, Yúpopíkv. Svwvnákv.

to Halter, Yúpo-pícetv.

to Halve, Sètv'cetv.

Ham, Hv'fē.

Hames, Rák’ko-menóckv.

Hame-string, Rák'ko-menóckvsétēwvnakv. 


\section{HAM}

Hammer, Svtókucē. Svtókv. to Hammer, Pat'cetv. Hand, En'kē.

Hand (left) Enkē-kvskv'nv. Hand, (right) Enk-vpérv.

Handle, Em-v'pè.

to Handle, Celáyetv.

Handkerchief, Noc'kv.

to Hand to, Aséncetv, Arencv'ketv.

to Hand-over, Wíyetv.

Handsome, Hērusē. Sémvnác. kucē.

Handsome, Sémvnáckv. Esfóyetv.

Hand-spike, Séten-kvwápkv.

to be Hanged up, 'Vtaretv.

to Hang up, v. c., Vtarícetv.

to Hang ones-self, Eátar'ketv.

to be Hanged, Em-aráhketv.

Hanging about, carelessly, Werhēatárketv.

Hanging loose, (like hair) Wéskē. Wérrē.

to Happen, Stomécetv. Moh'mvt-hákes.

Happiness, Afv'cketv.

Happiness, (his or her) Mafv'cketv.

to be Happy, Afánckúsetv:

Happy, Afan'ckusē. Afv'ckē.

Harbor, E'hetv.

Hard, Cvlv'twē. Wv'nhē. Takv'c. wè.

to be Hard, Wv'nhetv.

to Harden, Wvnhécetv. Wvnwrp'etv.

Hardware, Calkvs-hvtkē.

Hare, Cufē. Cufē-rákko.

Harlot, Hoktarv.

Harlots, Hoktarv'kē.

Harm, Ennokē. Nanv'comē.

to Harm, En-nokkícetv.

Harmless, Ahopáneko. Est-ennok'kíceko.

\section{HAR}

Harness, Afúscukcúlkv. Wákv hvrpē-cátē.

Harp, Féhpv.

Harrow, Sen-lúeyēpuéckv.

to Harrow, Sen-lúeyēpúecetv.

Harsh, Mayvkhv'mkē.

Harvest, Nak-lokcē. Nákē-vte. lókv. Híyo.

Haste, Enlv'pkē. Lv'pkē. to Hasten. Livpécetv. Hv'tēcrs. to Hasten, v. c. Lvpēcícetv. Hasty, Cvprk'ketv-enhēret. Hat, "Kapvtókv. Katvpókv. Hat, (beaver)Kapvtokv-echáswv. Hat-band, Kapvtókv-ēswvnákv. Hat (fur) Kapvtokv-telékmē. Hat, (palmeto) Kapvtókv-tálv. Hat, (wool) Kapvtokv-cúfē-es'se. to Hatch, Sv.kócetv. Hatchet, Pucúswucē.

to Hate, Homécetv Homecv'ketv

Hateful, En-homéckē.

Hatred, En-homéckv.

Hatter, Kapvtókv-háyv.

Haughty, Ekv-sv'mè.

to Haul, $\mathrm{Hv}^{\prime}$ lvtēpuécetv.

to Haul, Hvlátetv.

to Have, O'cetv. Océpetv. Ocv'ketv.

Hawk, A'yo.

Hawk, (black or squirrel) $\mathrm{A}^{\prime} \mathrm{yo}$ lv'stē.

Hawk, (fish) Hacekwv, Hvrónv. Hawk, (forked-tail) Hv'cē-yákpv. Hawk, (large-hen) Rvfókso. Hawk, (night) Sv'kper'kv. 'Ok' pérkv.

Hawk, (pigeon) Hvrónwv.

Hawk, (prairie) O'pa. Owv'kkv. Hawk, (rabbit) Rēyákkv.

Hawk, (red-tail) Hv'cē-cvtákv.

Hawk, (small hen) Hvcē-rofóksucè. 


\section{HAW}

Hawk, (sparrow) Sulelékwv. Hawthorn, (black) Seláwv. Hawthorn, (red) CuJē-túrwv. Hay, Pv'hē.

Hazle-nut, Kvtvrpv-pv'pkv. $\mathrm{He}$, she or it, Ëmē.

Head, E'kv.

Head-ache, Ekv-nókkē.

Head-stall, Ekv-sénhvlátkv.

Head of a stream, Uekíwv.

to Heal, Wicécetv.

to be Healed, Vyófetv. Wíketv. Wiképetv.

Healthy, Cvféknē.

Heap, Copósv.

to Heap up, Vtelóyetv. sícetv.

Heaped, Copóksē.

to Hear, Póhetv. Póhketv.

Hearer, Apohícv.

Hearing Póhē.

Hearse, Estē-pvsvtkē-escaunécetv-esculéckv.

Heart, Fékē.

Heart-burn, Efek-híyè.

Hearth, Tvk-témpē.

Heartless, Fékē-sēkó.

Hearty, Cvféknē.

Heat, (of the sun) Hv'so.

Heat Híyē.

to Heat, Hiyécetv.

Heathen, Estē-nakē-hērē-kérresēkót.

Heaven, Hv'lwē-tvlófv.

Heavier, Sén-húnnen.

Heavy, Hunnē. Hunhoyē.

to be Heavy, Hunnēmáhetv.

to Hedge about, Atohóp-kícetv.

Heel, El'lē-céskv. Lēcéskv.

Heir, 느onv'psē.

Hell, Tot'kv-rákko.

Hell-fire, Totkv-rak-elkv.

Helm, Esfiyátkv. Es-fiyátv.
HEL

Helmet, Sēko-kápvtokvn.

Helm's-man, Em-fiyátv.

to Help, Vnícetv.

Help, Vníckv.

Helper, Vnícv.

Hem, Em-vtéken.

Hemlock, Vcénvhó.

to Hem, Em-pēkócetv.

Hemp, Sowéna. Honókē-yekcē.

Hence, Yv'mv-áyat.

Henceforth, Múcv-vtékat.

Hêrd, Súlkē. Vpúekv.

Herdman, Vhēcícv.

Here, Yv'mv. Héyv. Hēyv'mv.

Hereafter, Er'topv'rv. Hvtētén.

Herein, Héyv-ófv.

Heresy, Mēkusv'pkv-vhákē.

Heretufore, Hvtē-múnko-múnkis.

Herring, Tókwucē.

to Hesitate, Vkerrícetv.

to Hew, Svtahécetv.

Hewer, Svtahécv.

Hiccough, Hēkok'ketv.

to Hiccough, Hëkok'ketv.

Hickory, O'cè.

Hickory-nut, Ocē-em-ēt'tē.

Hickory, (small kind) Oce-pēnos'sv.

Hickory, (Pig-nut) Ocē-tókfv. Ocē-tofkv.

Hickory-tree, Ocē-v'pē.

Hide (skin) Hvr'pè.

to Hide ones-self, Eh'ketv. Eh' . metv.

to Hide, Arvnáketv. Arvnáyetv. High, Homáhtv. Hv'lwē. Hvlháuwè.

to be Higher, Es-en-hv'lwetv.

Highest, Hvlháwan.

High-water, (flood) Uelaúkē.

Hill. Ekvn-hv'lwat.

Hill-country, Cefēhlófv.

Hill-side, $\mathrm{Hv}^{\prime}$ lwat-vfópkē.

Hillock, Ekvn-hv'lwucé.

Him, Em, éme. E. 


HIM
Himself, Émet.
Hind, (deer) Éco-et'skē. Eco-
hóktē.

to Hinder, Vnvtécetv.

Hind-foot, El'lè-yúpv.

Hinge, Soh-hueríckv.

Hip, Súksv. Empolókcv.

Hire, Hvlwécet.

to Hire, Hvlwécetv.

Hireling, Hvlwehócē.

His, hers, or its, Enákē.

to Hit, Nv'fketv. Nvfkv'ketv.

to Hitch up, Atv'kkatícetv.

to be Hitched up, Atvkkáyetv.

Hither, Hēyv'mv.

Hitherto, Hiyómē-vlakúecet.

Hives, Hotv'pkv.

Hoar-hound, Éssē-sv'pvhv'thákusat.

Hoarse, Nok-súmkē.

Hobbles, El'lē-sēwvnákv.

Hoe, Esluékv.

to Hoe, Lúyetv. Cvpíyetv.

Hog, Súkhv.

Hog-meat, Súkhv-vpéswv.

Hogs, Sukhv'lkē.

Hog's-lard, Sukhv-nēhá.

Hog-weed, Ráwrhv'kv.

to Hoist, Vcemēcícetv.

to Hold between, Tenhvlv'tetv.

to Hold up the head, Nvlv'ksetv.

to Hold up one end, Cvkescícetv.

to Hold, Hvlv'tetv. Vyókcetv.

to Hold it to, Es-em-wíyetv.

to Hold up, Kiyáhketv.

to Hold down, Svténketv.

Hole, (in the ground) Ak-súfkē.

Ekvn háukē.

Hole, Vhaúkē.

Hole, Rolvk'kē.

Hollow, (earth) Kvn-súfkē.

Hollow, (of the foot) El'le-yunáktv.

Hollow-hearted, Fékē-: èkó.

Hollow, (tree) To-haúkē.

HOL

to Hollow out, Kófetv.

Holly-tree, Es'sē-fv'skē.

Holy, Hvsántkusē. Hvsv'tkē.

to be Holy, Hvsv'tketv.

Holy-day,Net'tv-hvsv'tkē. Nettvvcákē.

Holy Ghost, Pueyvfekcv-hvsv't kē. Pueyvfékcv-vcákat.

Holy Spirit, Púeyvfékcv-vcákat.

Home, Hútē.

Home-sick, Ehútē-vpohyv'kē.

Hominy, Af'kē. (Fulótkv.)

Hominy (lye) Súkv.

Hominy-mill, A'fkē-sénfulótkv.

Hone, Svkáskv. Es-fvscékv:

Honest, Fv'tcē.

Honey, Fo-en-cv'mpē.

Honey-bee, Fo.

Honey-bee, (Drone) Fo-ue-cáwv. Honey-bee, (queen) Fo-em-mék' ko.

Honey-comb, Fo-hútē.

Honor, Vrákkúeckv.

to Honor, Vrákkuécetv.

Hoof, Ellv'ksv. Lv'ksv.

Hook, Es-halv'tetv.

to Hook with the horn, $\mathrm{Yv}^{\prime} \mathrm{pe}$ es'sekéyetv.

to Hop, Cē-kósetv. Tásketv.

Hope, En-nénē-hécetv. Enhonrkv. Enhónretv.

to Hope, En-nénē-hécetv. Honrv'ketv.

Horn, Yv'pẽ. Pofkétv.

Hornet, Afénca.

Horn-spoon, Yv'pē-hvk'kv.

Horns, (of cattle) Wákv-yv'pē.

Horrid, Penkv'lket.

Horse, Co-rak'ko.

Horse-fly, Róno.

Horses, Corakkv'lkē.

Hospitable, Yvmv'sē.

Hot, Hiyv'kē. Hihóyē. Hì'usēe.

Hot, Híyē, Sén-híyē, Híye-máhēe 


\section{HOT}

Hotter, Sen-híyë.

Hottest, Hiyē-máhē. Híyē-tvmáhè.

Hound, Éfv-wóhkv.

Hour, Hv'sē-vkérkv.

House, Cúko. Hútē.

House-fly, Cána.

Household, Hutv'lkē. En-cúkovtehkv'lkè.

to Howl, Wohóke!v.

How? Estómet?

How-great? En-rak'kē-estómvsen?

How many? Nvcómen? Nvcomá?

How much? Estómvsen-nvcómen. Estomvtéken? Nvcomá?

How soon? Enlvp'kē-estómvsen. How soon? Ayv'k-hv'mkusēn. to Hug, Otáketv.

Hull, Ehvr'pè.

to Hum, Hvmmv'ketv, Renēnél$\mathrm{ke}^{\dagger} \mathrm{v}$.

Humble, Eyáskē.

to be Humble, Eyásketv. Sēyaskēháketv.

Humble ourselves, Ekvncvpuécetv.

Humble bee, Fo-tēnétkē.

Humility, Eyásketv.

Humming-bird, Hvn'rv-cókwucè.

Hump, Kúphè.

to Hump, Kopuknícetv.

Hundred, Cúkpē-hv'mken.

Hundred pounds, Vtárkv-cúkpēhv'mken.

Hunger, Eláuwetv. Láuwetv .

Hungry, Eláuwē. Láuko.

Hunt, Faka.

to Hunt, Fáyetv.

to Hunt afar off, Erhopóyetv. Raf-áyetv.

Hunter, Fáyv, Fáyepv.

Hurricane, Hótvlē-rákko. Hótvlēhoyánv.

\section{HUR}

to Hurry, Lvpécetv.

to Hurt, En-nokkícetv. Nokkícetv.

to Hurt over again, Vlv'ssetv. to Hurt ower again, V!v'skētv. Husband, Ehē. Hē.

Husk, Tvl-es'sē. Tvlako-hakē. to Husk, Fóyetv.

Hymn, Yvhíketv. Es-yvhíketv. Hymn-book, Nakcókv-esyvhíketv.

Hypocrisy, Mekusv'pkv-vháyv. Hypocrite, Svháyv, Vháyv. to be a Hypocrite, Svháyetv. Hypocrites, Mekusv'pkv-vhayv'lke.

Hypocritical, Svháyē.

Hyssop, Kvn-pókhucē.

\section{I.}

I, V'nē.

I alone, Vntv'lket.

Ice Hetútē.

Idle, En-hólrē. Yvmáhkē.

Idleness, Yvmáhkv.

to Idle, Nettv-yvmáhketv.

Idle tales, Nanv'k-oketv.

Idol, Nak-vhákè.

Idolaters: Nak-vhákē-vfastv'lkē.

Idolatry, Nak-vhákē-vfástetv.

If, Nómat.

If it can be done, Momē-tetáyenomat,

If nothing prevents, Estónkon.

If not so, Mómekó-nómat.

If so, Móme-nómat.

Ill, Púlsē, Ecáyē. Enok'kē.

Image, Vhákē.

to Imagine, Emē-tehósetv.

to Imitate, E-sv-háyetv.

Immediately, Ayvkhv'mken.

Immediately, Vpákusen. Mómat-vpáken.

to Immerse, v. c. Aksúmécetv. 


\section{IMM}

to be Immersed, Aksúmketv.

Immerser, Aksúmkv.

Immersionists, Aksúmkv'lkē.

Immortality, Hesáketv-yúksvsēkó.

Impatient, Kusápēe.

Impediment, Vtv'ckv.

to Implore, Em-póhetv.

Important, Hērēmáhē.

to be Impossible, Mon'ko-tayósetv.

to Imprison, Cúko-yek'cv-vpíketv,

Imprisoned, Pihókv-cúken.

Improper, Fvtc'v-tokós.

to Improve, Vhērícetv.

Imprudent, Hoporēnè-máh'eko.

Impudent, V'lsēko. Em-punáyvkē-onkat.

to be In, Vpíketv. Vtéhketv.

In, Orófvu, V'lkan. Ofvn. Ofy. Of. Vtē. Vpíkē.

Inch, Vhopákucē.

In a little while, Hofúnosè.

In a row, Sēnécē.

to Increase upon it, Vsúlketv.

Increased, Ohvtv'lvkē.

Indeed, Mehénwvn.

Independent, V'nts-kómet. CV'ckómē.

Independent, Em-punáyvkē-ónkat.

Indian, Estē-cátē.

Indigence, Kusv'pkv.

Indigo, Sok-holàttéckv. Esholattéckv.

Industrious, Herómē.

Inequality, Wesáhtē.

Infamous, Holwayécē-máhē.

Infant, Estúcē.

Infirmity, Ehapérkv.

Inflammation, Hopv'nkē.

Inflammation of the bowels, Nvr'. kēófv-hopv'nkē.

\section{INF}

Inflammation of the breast, Hok' pē-hopv'nkē.

Inflammation of the liver, Lúpēhopv'nkē.

Inflammation of the lungs, Opv'fkv-hopv'nkē.

Inflammation of the spleen, Lúpēcápko-hopv'nkē.

Influenza, Yukseh'netv.

to Inform, Monáyetv.

Inhabitant, Este-yv'mv-ekv'nvfúllat.

to Inhabit, Mv-tvlófv-líketv.

to Inhale, Esē-vhēsáketv.

Inheritance, Hēckvránvten.

Iniquity, Holwayéckv.

to Injure, Ahopánetv.

Ink, Ue-lv'stē.

Ink-stand, Ue-lv'stē-vcv'nkv.

In like manner, Etvpómen.

In me, Vcófv.

In no wise, Estomusáten. Estómvten.

to Inquire, Vpóhetv.

In the room of, Mékko-cúken.

Insane, Háco-háket.

Insect, Wenákuce. Wenahókuse.

Insomuch, Svhērēmáhekv.

Inspiration of the Holy Spirit, Púeyvfékcv-vcákat-ēmvháyetv.

to Inspire, Es-vhēsáketv.

Instantly, Lv'pkusen. Lvpkusátē.

to be Instead of, Yopósketv.

Instead of, Vráhkv. Ayopósketv. Yopóskē.

Instep, Est-ellē-ēnáktv.

to Instruct, Em·mvháyetv.

In such a way, Yóman, Yómat.

to Intend, Em-vlósetv.

to Inter, Hopéletv.

to Intercede for, Em-êten-her'ketv.

Interest, Oh-hóntv. 


\section{INT}

to Interpret, Yvtéketv. tekhóyetv.

Interpreter, $\mathrm{Yv}^{\prime}$ tekv.

Intestines, Fékcē.

In the beginning, Hvtecéskv.

In the morning, Hvthíyvtkē.

In the first place, Káwv.

In the house, Nvthófv.

Into, O'fvn. Res.

to Intoxicate, Máh-yúmecicetv.

Intoxicated, 'Máhyúmkē.

to Introduce, Em-oh-onáyetv .

Invisible, Hec'keko.

to Invite, En-huéhketv.

Inward, Ena-ófv.

Ipecacuanha, Svwótkv-lánē.

Iron, $\mathrm{Cv}^{\prime}$ to.

Iron-bars, Cvto-tvpéksat.

Iron-mine, Cvto-enkórkv.

Iron-rods, Cvto-polókosē.

Irregularly, Wesv'ktē.

Is, Omes. Os.

I say, Nókis.

Is it? Náken-mómá?

Is it so? Móma?

Island, O'té.

Is not, Rónks, Momē-rónks.

Is nothing, Estómv-tókos.

Issue of blood, Cátē-fíhnē.

Isthmus, Ak-kúrkē.

It can be done, Mometás.

Itch, Tóskv.

I think so, Mómes-kómis.

It is, O'ces. Mómes. Momet.

It is Enough, Estrmáhets.

It is in, Ak-ócat.

It is like it, Mv-ómes.

It is new, Múcvsát.

It is not, Tóko.

It is so, Mómēs. Mómusen.

It is that, Mómat.

It must be, Mómē-tetás.

Itself, Etáwvn.

Ivory, Yúpo-lowák-en-nútē.
JAC

It was, Tátes. Mómvnks.

It was not so, Momákat-tates.

\section{J.}

Jackdaw, Svkkelv rákko.

Jacket, Kápv-kocoknē.

to Jade, Hotosícetv.

Jailer, Cúko-yékcv-vhecícv.

to Jangle, Etehánetv.

January, $\mathrm{Rv}^{\prime}$ fo-cúsē.

Jar, Mutésv.

Jar fly, Suwesuwē.

Jaw, Notv'kha.

Jaw-bone, Notvk'ha-fúnē.

Tay-bird, Tv'sē.

Jealous, Fek-cvk'hē.

Jeans, Cúfe-es'sē-vpáket.

to Jerk, Hvláttuécetv.

Jerusalem, Celúslvmēn.

Jerusalem-oak, Wēlánv.

to Jest, Vnatóketv.

a Jester, Vpélkv-háyv.

Jesus, Teyósē? Césvs.

Jesus Christ, Césvs-klis't.

Jews, Cusv'lkè.

Jewel, Nak-vcáke.

Jews-harp, Es-hayéckucē.

to Jingle, Svm-vnécetv:

Job, Cop.

Jocular, Vpélkv-háyv.

to Join together, Tehv'lvte-pué-

cetv. Tétékketv. Etóhkv'l-

ketv.

Joiner, Sētēkékv.

Joint of body, Ena-tórpē.

Joint of tree, Eto-toh-tékkekv.

Joints, Etē-téketv.

Joist, Tohkákv. Osv'lkv.

a Joke, Vnatóketv.

to Joke, Vnatóketv.

Jole, Notákhv:

Jordan, (river) Cotvnē.

Journey, Sunēckē.

to Journey, Tvlēpóretv. 


\section{JOY}

Joy, Afv'cketv.

Joyful, Afvckè.

Judah, Cúta.

Judas, Cutvsēe

Judea, Cutēa.

Judge, Oh-fvtcēcr. Fvtcēcr.

to Judge, Oh-fvtcécetv.

to Judge, Fv'tcetv.

to Judge, Oh-fv'tcetv.

Judgment, Oh-fvtcéckv. Frtcéckv. Oh-fvtcētetáyē.

Judgment-day, Oh-fvtcéckv-net'tv.

Jug, Mutésv. Luc'uwv.

Juice, Opúswv.

July, Híyucē.

to Jump somerset, Tvtásketv.

to Jump Tásketv. Táspóket\%. Táskécetv.

to Jump down, Ak-tasécetv.

to Jump off, Ratásketv.

June, Kv'co-hvsē.

Junior, Mvnet'tes.

Jury, Fvt'cēcv'lkē.

Just, Fv'tcē.

Just as, Vtékusē.

Justice, Fv'tcv. Fv'tcetv.

Justification, Pum-fvtcécetv.

Justifier, Fvtcécv.

to Justify, Fvtcécetv.

Just now, Enk-hv'ttv. Múcvtan.

Juvenile, Mvnéttat.

\section{I.}

Katy-did, Kvsv'sv.

Keel-boat, Perro-cápkē.

Keen, Fv'skē. Rvfónkusē.

to Keep, Vhécícetv.

to Keep or preserve, Vcayécetv. Keeper, Vhëcícv.

Keg, Towvnv'kucē.

Kernel, Efékē. Em-vpéswv. Nérkv.

Kettle, Vrkv'swv.

\section{KET}

Kettle, (brass) Etē-hvrkv'swv.

Key, Es-haúwēckv.

to Kick, Réfketv.

to Kick back, Sóh-réfketv.

to Kick, Oh-réfketv.

to Kick back, Hoféletv.

to Kick up the heels, Kvyúknetv.

Kid, Cowátucē.

Kin-folks, Nakvlkē-vpokē.

Kidney, Túcē.

to Kill, Pvsv'ttetv. Elécetv. Lécetv.

Kill-deer, Towéhtv. Colécv.

Kind, Herómē. Enlopícē.

to be Kind, Vcayécetv.

Kind, (species) Tecákáyē.

to Kindle, Kolécetv. Técetv.

Kindred, Em-estv'lkē.

Kine, Vpuékv.

King, Mékko.

King-bee, Fó-em-mékko.

Kingdom, Oh-mékketv. Tvlófv.

Kingdom of God, Hesak. Em-ohmekketv. Hesak-émē-tvlófv.

Kingdom of heaven, Hvlwe-ohmek'ketv.

King-fisher, Tv'ssvsv'nv.

King-snake, Cet'to-mek'ko.

Kinsman, Ena-hv'mkē.

Cennakè.

Kinsmen, Ena-hvmkvlkē. Cennakvlkè.

to Kiss, Vfv'nketv.

Kitchen, Hómpetv-hákv-cúko.

Kitten, Posucē.

Knavish, Mv-ker'retv.

to Knead, Cvlápetv.

Kneading-troush, Vcvlv'petv.

Knee, Torkówv.

Knee-joint, Torkówv-tohkékekv.

Knee-pan, Torkówv-oh-líkv.

to Kneel, Toh-kéketv. Tv'kko= kéketv.

Knife, Esláfkv. 


\section{KNI}

Knife, (pen) Eslátkucē.

Knife-scabbard, Esláfkv-hútē.

to Knit, Tv'retv.

to Knit-together, Tēwe-téknetv.

Knitter, Nak-tárv.

Knitting-needle, Tv'retv-es-ropot'tv.

to Knock, Náfketv.

to Knock down, Tēkáyetv.

Knot, Tórpē. Cutuknē. Cukcórkē. Cēréknē.

to Knot, Cukcóretv.

Knotted, Cukcórkē.

to Know, Ker'retv.

to make Known, Kerkúecetv.

Knowledge, Hoporénē. Kerr'etv.

Known, (to make) Kerkuécetv.

Known, (to make) Astén-kerkúecetv.

Knuckle, En'kē-tor'pē.

\section{I.}

Labor, Vtótketv.

to Labor, (work) Vtótketv. Vtothóketv. Vtotkv'ketv.

Laborer, Vtótkv.

to Lack, En'kusápetv.

Lacking, Emoréks. Enkusv'kē.

Laconic, $\mathrm{Pu}$ v'kv-kocúknet.

Ladder, Acémketv. Soh-cémketv.

Ladle, Svkcaúkv. Rē-esrékkíc$\mathrm{kv}$.

Lady, Hóktē-vcákv.

Lady-like, Hóktē-vcákē-ónt.

to Lag, Yupák-látketv.

Lake, Akhv'sē. Uehv'sē.

Lamb, Yvpefíkucē.

Lambs-quarter, Táhwē.

Lame, Vnv'ttē. Yekótē. Cekósē.

Lameness, Yekótketv.

to Lament, Wáhketv.

Lamentat on, Wáhketv.

Lamp, Kúlkē-soh·huéra.

\section{LAN}

Lancet, Catē-escaúkv.

Land, Ekv'nv. Fak'kē.

to Land, (a boat) Acáyetv.

to Land with, Svcáyetv.

Landing, Vcákv.

Land-mark, Kvn-sátkv.

Lane, Taptáhan.

Language, Punv'kv.

Languid, Mayónkusē.

Lank. Tvwáknē.

Lantern, Kulkè-hutē.

to Lap, (with hand) Apvkléyetv. to Lap, (as a dog) Lásetv. Apvklíketv.

to Lap, Lv'plvpécetv.

Lard, Súkhanèha.

Large, Rakkē. Rakrvkē.

Larger, Sen-rakkē.

Lark, Hv'nvcēlu.

Lash, (of a whip) Sen yukfv'nkv. to Lash (whip) Rokáfetv.

Last-day, Nettv-espokē.

Last, (for shoes) Estellepíkv-ofvempíkv.

Last, (in number) Espókē. Réspokè.

Last-night, Nerēísē.

Last summer, Méskē-v'nkē.

Last week, Net'tv-cákucē-v'nkē.

Last-year, Orólopē-hv'mkē-v'nkē. Lastly, En-spókē. Er'espókat.

Latch, Vhaúk-svtvkkákv.

to Latch, Svtvkkáyetv.

Late, Yúpv. Yáfkusēe.

Late, (day or night) Net'tē.

Lately, Hvtusv'lkē.

Latent, Vrvnákē.

Lath, Oh-sv'ikv.

Laudable, Akvsv'mv'kē-tetás。

Laudanum, Es-nucicéckv.

a Laugh. Vpelkv. Vpelúsv.

to Laugn, Vpéletv. Vpēlúsetv.

Laughable, Vpēlickv. Vpēlícetvtetás. 


\section{LAU}

Laugher, Vpélv.

Laughter, Vpélkv.

Law, Vhákv.

Lawful, Tetáyvtē. Vháketv.

Lawyer, Vhákv·háyv.

to Lay down the fence, Enlētáfetv.

to Lay down, Wakkécetv.

to Lay across, Vk-wakkécetv.

to Lay beside, Vtak-hv'ke-wakkécetv. Vpoktícetv.

to Lay by, Wíketv-en-hoyv'nēcícetv.

to Lay eggs, Sícetv. Káyetv.

to Lay in, Oh-póketv.

to Lay on, Oh-wak'kecetv. Ohkáyetv.

to Lay over, Wíketv-palhv'mken. to Lay up, A-áyetv. Herícetv.

Lazy, En-hon'rē.

to be Lazy, Enhónretv.

Leach, Kapúsko. Kvpē-escáfkv. to Lead, Sēvpáyetv.

to Lead, Evpáyetv. Ahvlv'tetáyetv.

to Lead many, Ahvlvthícetv.

to Lead us to, Sēpoháyetv.

Lead, Rè.

Leader, Evpárv. Sevpáyv.

Leading-line, Es-halv'tetv.

Lead-mine, Rē-enkórkv.

Lead-pencil, Rē-es-hotcíckv.

Leaf, (of a book) Nakcókv-es'sē.

Leaf, (of a tree) Eto-es'sē.

Leafless, Es'sēe-séko.

League, Vker'kv-tutcénen.

to Leak, Sih'netv.

Leaky, Acófkè.

Lean, Trwákne.

Vpestv'lkē. Oyókhē.

Leaned against, Vcak'ket.

Leaned back, Vpésketv.

to Lean against, v. c., Vtcacícetv. to Leap, Tas'ketv.

\section{LEA}

to Learn, Ker'retv. Ahayáketv. Learned, Kērrá.

Learners, IKerrepv'lkē.

Learner, Kérrv. Vháyv.

L،east, Encútkusē. Lopóntskusat.

Leather, Cus'sē. Wakv-hv'rpē. cáte.

Leather, (buck-skin) Cus'sē-lánē.

Leather, (sole) Stellepíkv-ofv-pácetv.

Leather, (string) Cussē-sélkv.

Leather, (upper) Cus'sē.

to Leave, Enkvpv'ketv. Vpáyetv.

to Leave a part, Ahósketv. Ahosēcícetv.

to Leave off, Wiketv. Em-wiketv.

Leaves, To-éssē.

Leaven, Es pakkueckv. Tóksē. to Leaven, Pákketv.

Leech, Vcélkv.

Left, Kvskv'nv.

Left-hand, Enk-kvskv'nv

Left-handed, Enkē-kvskv'nv.

Left-side, Akvskv'nv.

Leg, Hv'ckewv. Hvtéwv.

Leg, (calf of) Ellen-páko.

Leg-bone, Hv'ckep-fúnē.

Leg, (lower part) Lvtcéksē.

Legal, Vhákvtósē.

Leggings, Hv'fv-téhkv.

Legible, Oh-onáyv'kētayē.

Legion, Mivhonkv'tkv-cakkákseko.

Lemun or sour orange, Yvláhvtóksē.

to Lend, Pv'letv. Pvlépetv.

Lender, Pv'lv.

Lending, Ofv-em-pv'lekv.

to Lengthen, Capkúecetv. Orv'fketv. Orvfécetv.

Leopard, Ue-kácv.

Leper, Léppv. 


\section{LEP}

Leprosy, Léppv'sē.

Length-wise, Vcápkē.

Less, Nv'comē. Sencútkē.

to Lessen, Vkasécetv. Akácetv. Cutecícetv. Akáceyetv. Sopotécícetv.

Lessen, Hécetv.

Lest, Witéyē. Mómeko-nómat. Let it be forever, Múnkekvs.

Let it be so, Mómekvs. Momépekvs.

to Let, Em-akvsv'metv.

to Let down, Hvtvpécícetv.

to Let down on, Oh-hvtvpēcícetv. Letter, (of alphabet) Punv'kvlalv'nkv.

Letter, (written) Nakcókv hotc'è. Nak-hótcē.

Lettuce, Lánē-pápv.

Level, Trpénksusē.

Liable, Oh-onayv'kē-táyē.

Liar, Lak'sv.

Liberal, Yvmv'sē.

Librarian, Nakcókv-vhecícv.

Lice, (small) Wéskv. Wéskucē. Eckv.

to Lick, Lásetv.

Lid, Oh-rv'nkv, Sohrvnkv.

to Lie, (tell lies) Láksetv. Eóketv.

to Lie, (tell lies upon) Oh-láksetv.

to Lie about, Estómis-wákketv.

to Lie across, Awelépk-wákketv.

to Lie against, (beside) Awákketv.

to Lie around, Wákket-afulétketv.

to Lie back, Apósketv.

to Lie before the fire, Tacúnketv.

to Lie between, Nvrkv'pv-wákketv.

to Lie by, Alúmhetv.

to Lie down, Wákketv. Wakhóketv. Lúmhetv.

\section{LIE}

to Lie in wait, Em-ehákē-wákketv.

to Lie in wait with, Es-en-kv'n. hetv.

to Lie in water, $\mathrm{Ak}$-wákken. $\mathrm{Ak}$ lúmbetv.

to Lie on, Oh-wákketv.

to Lie on one's side, Afeklúm. ketv.

to Lie over, Palhv'mke-wákketv. to Lie under, Ellécv-wákketv.

Lieutenant, Nak-ēssekv.

Life, Hesáketv.

Life-everlasting, Hesáketv-yuksvsēko.

Life-everlasting, (an herb) Ahalopv'kcv.

Life-less, Hesákeko-ómet.

to Lift, Kvwápketv. Kvwápetv.

to Light a fire, Kulécetv, Tvkolécetv.

Light, Hiyáyvkē.

Light, (not heavy) Tvhóknē. to be Light, Tvhóknetv.

Light-bread, Tvklíkē-pákiko.

to Lighten, Vtoyēhv'ttetv.

Light-fingered, Enkē-wesákē-tvhóknē.

Light-headed. Ekv-tvhóknē.

Light-horseman, Rák-oh-kákv.

Lightness, Ahéckv.

Lightning, Vtóyehv'ttē.

Lightning-bug, Kuleh'pv.

Lights, Opv'fkv.

Like, On. Ont. Ot. Omē. Un'kv. O'musē.

Like as, Omē. Omvtéhkvn.

to Like, Em-€nhēretv. Mahlústetv.

to make Like, Omēcícetv.

to Liken, Omécetv. Svhopáyetv. Like-manner, Matvpómen.

Like this, Héyv-omán.

Like to, Omv'kurē. 


\section{LIK}

to do Likewise, Matvpómécetv. Likewise, Etvpómen. Matvpómusē.

Lily, (pond) Ak-kotórkv.

Limb, (of a tree) Elv'cē. Lv'cē. Limb, (of the body) Éna-lv'cē.

Limber, Luwákē. Fenókē.

to make Limber, Luwácetv.

Lime, Cvtt'o-nékrē.

Lime-stone, Cvtto-nekríckv.

to Limp, Cēkóssetv.

to Limp, Cē-kúnnetv.

Line, (rule) Sátkv.

Line, (rope) Fv'kv. Pvtícetv.

to Line, Em-pvtícetv.

Linen, Nak-hv'tkē-tvskócv. Hvnvwélv.

Liniment, Nak-essíkv.

Lining Ofv-em-pvtíckv.

Link, (in a chain) Tetvkhákv.

Linked, Elv'cē.

Lion, Estē-pápv.

Lip, Cuk-hvr'pē.

Liquid, Kvsv'mrē.

to Listen, Mapohícetv.

Little (but) Anv'comē.

Little, (small) Cútkē. Lvpon'skusē. Cútkusē.

Little, (in quantity) Estómusen.

Little better, Sv-mómusē.

Little boy, Cepánusē.

Little while ago, Hv'tosēe. Hvtētusat.

to make Live, Wēnahúecetv.

to Live, Wēnáketv. Wēnahóketv. Hēsáketv.

Liver, E-lúpē. Lúpē.

Living, Hesákē. Wenákē.

Living things, Wēnahókē.

Lizzard, En-cakv'spv.

Lizzard, Táksē-púlkv. Vtá.

Lizzard, (green) Hacúklepá.

Lizzard, (ground) Kvncáyucē.

to Load, Vtéhety.

\section{LOA}

Loaf, Vnórv.

Loaf-sugar, (white) Vsókula-hv'tkè.

Loam, Fak'kē.

Loathsome, En-homéckē.

Lobelia, Hécē-ómē.

Lobster, Sv'kco-rákko. Sv'kco.

Lock, Sémvlíkv. Cúko-semvlíc$\mathrm{kv}$.

Lock of hair, Téwv.

to Lock, Semlícetv.

Lock-jaw, Notv'khv-yékcē.

Locust, ( 7 year) Suwésuwē.

Locust, Tv'ffo-nóksv.

Locust, (7 year) Ayépv.

Locust-tree, (bla.ck) Coháhtv.

Locust, (honey) Kvtókwv.

to Lodge, Fekhúnetv. Fekhunépetv.

to Lodge, Fekhunécetv.

Loft, Oh-tópv.

Log, Éto.

Log-chain, Cvto-telácv-rákko.

Loggerhead, Kálfo.

Loins, Etetac'kv.

to Loiter, Mvcéwetv.

to Loll, Vtcáketv.

Lonely, Eyácē.

Lonesome, Puyácetv. Pohyv'kē.

Long, Cápkē. Cápcvkē.

Long moss, Assúnwv.

Long ago, Hofúnē-máhē.

Long ago, Likē-múnken.

Longer, Sencápkē.

Long time, Hofúné. Vhofunē.

Longwise, Vcápkē.

to Look, Hécetv.

to Look about, Vfvnnáketv.

to Look after, Vhécetv.

to Look at one's self, Ehécetv.

to Look to or on, Oh'-hécetv.

to Look towards, Ehécetv.

to Look up, Ahécetv. Vfvnaketv.

to Look behind, Ahécetv. 


\section{LOO}

Looking-glass, Es-takhéckv.

a Loom, Estar'kv.

Loom-harness, Vfúscuk-cúrkv.

Loose, I'ulóhē. Rēcópkē.

to Loose, Rēcópetv. Coróketv.

Fēcrpetv.

to be Loose, Yulóhetv.

Loosed, Recópkē.

to Loosen, Yulohícetv.

Lord, Pucásē. Cehófv. Hesaketv'mes'e.

Lord's-day, Hesáketvmesé-en. néttv.

Lord's-people, Hesáketvm-emestv'lke.

Lord's-prayer, Hesák-em-mekusv'pkv.

Lord's-supper, Hesak-en-hómpeta.

to Lose, Sumēcícetv.

to be Lost, Sumēcetv. Súmketv. Lost, Hossē. Sumécē.

Lot, (for stock) En-tohópkē.

Loud, Yékcē.

Lounging, Wérkē.

Louse, Ec'ka.

Love, Vnokéckv.

Love of God, Hesák-em-vnokéc$\mathrm{kv}$.

to Love, Vnokécetv. Vnokēcrketv.

Loved, Vnokéckē.

Lovely, Vnokéckē.

Loving, Encákusē.

Loving each-other, Eten-okecv'kè.

Low, Kvncápē. Ellécv.

Lowest, Ellécv-máhē.

to Lower, Kvcrpuécetv.

Lowermnst, Ellécv-máhē.

Lowly, Kvncápusē. Kvncvpákusat. Kvncvpáyē.

Loyal, Em-mékko-em-eyáskē.

Lucid, Ker'kv-hērē.

\section{LUC}

Lucky, Em-vnv'ckē.

Ludicrous, Vpeléckē.

Luke-warm, Vklek'husē. Lékhē. to be Luke-warm, Lekhícetv.

Lumber, To-fókv.

Luminous, Hiyáyvkē.

Lump, Cerékkvnē. Naklíkē.

Lumpy, Ceréncēkē.

Lunatic, Hvrésē-vlícv.

Lungs, Hopv'fkv. Opv'fkv.

Lye, Kv'pē.

Lye-hominy, Súkv.

Lye-hopper, Kvpē-escáfkv .

Lying down, Wákken.

\section{II.}

Mad, Cvpvk'ke.

Mad-dog, Efv-háco-hákv. to Madden, Crpvkkuécetv.

Maggot, Cúntv.

Magnanimous, Vkéncv-rákkē. to Magnify, Rakkuécetv.

Magnified, Vrákkē.

to be Magnified, Vrákketv.

Maid, Hunv'nwv-seko.

Major, Sen-rákkē.

Make cakes on hearth, Tvnorícvs.

to Make new, Mucvsécetv.

to Make fruitful, Honv'psécetv.

to Make, Háyetv. Háhícetv.

to Make a fire, Etécetv. Trkētécetv.

to Make good, Mahécetv.

Maker, Nak-háyv.

Male, Hunv'nwv.

Mallet, Sv-nv'fketv.

Man, Estē-hunv'nwv. Estē.

Mane, (of horse) Nok-es'sē. Téwē.

Mange, Tóskv.

to be Many, Sv'setv.

Many, Súlkē, Vnv'comē.

Many (very) $\mathrm{Nv}^{\prime}$ comē-máhē.

Map, Ekv'nv-svhopákv. 


\section{MAP}

Maple, Héno. Heno-cv'mpv.

Marble, Sec'hetv.

Marble-quarry, Sec'hetv-eskor'$\mathrm{kv}$.

March, (month) Tasáhcucē.

to March, (in tiers) Tv'lvlv'ketv。

Mare, Corak'ko-hóktē.

Mark, Sátkv. Vkérkv.

to Mark, Vkérkuécetv. Sátetv.

Market, Nak-wikv-v'lkan.

Market-place, 'Tv'lemē-v'lkē.

Marriage, Etepáyetv.

to give in Marriage, Etē-páyēpúecetv.

to give in Marriage, Etē-páyēpuehohcetv.

Married, Ep-ayē.

Márrow, Falówv.

to Marry, Tẻhalv'tetv. Epáyetv. Etepáyetv.

Marsh, Aksumóhē.

to Mash, Telekmicetv.

Marshy, Aklowáhē.

Martin, Cekúlko.

Martingale, Hókpē-sen-hvlátkv.

Martyrs, Mekusapv'lkē-elēcat.

to Marvel, Estomáhetv.

Marvelous, Estomáhē.

Masculine, Hunv'nwē.

Mason, Cvto-cáskv.

Mast, Súkhv-enhompetv.

Mast, (of ship) Em-pokv'pē.

Master Pucásē.

to Master, Pucásetv.

to Match, Sem-eteháyetv.

Matches, Tótkv-setéckv. Setē-

cetv. Svhvtéckvtē.

Mate, Pvlsē. Tem-pálvsē.

Matt, Kóha-tv'rkē.

Mattock, Vcúknv.

Maul, Eto-sv-nv'fketv.

Maw, Pásv.

May-apple, Kvpolóyē.

May be, Wites.
MAY

May, (month) Kē-hv'sē.

Me, Vn'en. Vn. V. Vm.

Meadow, Pv'hē-cúswv. Pató。

Meagre, Rosvp'kv.

Meal, Hóckvtē.

to Mean, Náketv.

Mean, Holwáyēcē.

Meaning, Vrahécē.

Measles, Fo-tvk'letv.

to Measure, Șrhopáyetv. Vhopáyetv. Vkerkúcetv.

to Measure in length, Vhopáketv. Measure, Vhopákv. Svkérkv.

Measurement, Vkérkv.

Meat, Vpéswv.

Meat, (baked) Vpéswv-nórē.

Hotópkē.

Meat, (boiled) Vpéswv-hor'kē.

Meat, (dried) Vpéswv-kvr'pet.

Meat, (fried) Vpéswv-svk-mor' kê.

Meat, (roasted) Vpéswv-eckópkè.

Mechanic, Nák-háyv,

to Meddle, Naorícetv.

Meddling, Naorícet. Mvtes-hērs.

Mediator, En-fvtcécv. Etenhérkv.

Medicine, Heléswv.

Meek, Eyáskēe Eyáskakusátē.

to be Meek, Kvncv'petv. $\mathbf{Y}_{\text {v- }}$ mv'sketv.

Meekness, Yvmv'skv.

to Meet, Vnrv'petv. Rvnrv'petv.

to Meet each other, Etehécetv.

to Meet each other, Setē-hécetv.

to Meet, Vfv'tcetv.

Meeting-house, Mekusv'pkvcúko. Nakvftetv-cuko.

to Melt, Tvkv'fetv. Rek'ketv. Káfketv.

to Melt and drop, Sētéketv.

Melted, Vlékwē. Rek'kē Káfken. 


\section{MEM}

Member of the body, Ena-lv'-cē. Memorial, Es-vkerrickvn. to Mend, Mvherícetv.

Mended, Maheríckv.

Merchant, Es-nésv. Nésv.

Merciful, Em-mer'rusē. Mer'rvkate.

Mercy, Mer'retv. Mer'kv.

Mercy, (to have) Mer'retv.

Mercy, (of God) Hesakem-mer'$\mathrm{kv}$.

to Merit, E-en-heckuécetv. E-encákkuécetv.

Merry, Afvckè.

Messenger, Punv'kv-sárv. Sárv. Messiah, Mes'sia.

Metal,(easily melted)Rek'kē-tayē. Metal, Cv'to.

Meteor, Kococúmpv-senépkv.

Methiglin, Púncē.

Methodical, Vhákē-acvkáyē.

Methodists, Oh-kalv'lkē.

Mexican, Espánē.

Mid-day, Net'tv-nvrkv'pv. Fvtcv-líkē.

Middle, Nvrkv'pv.

Middle-finger, Enkē-nvrkv'phúera.

Middling, Mv'tes. Hēres.

Midnight, Nerē-nvrkv'pv.

Midst, Nvrkv'pv.

Might have called, Enhuéhkétetáyvtes.

Might be, Witēs.

Mightier, Svn-yékcēs.

Mighty,Yékcē-máhè.

Mighty-one, Estē-póhket.

Mild, Eyáskē. Lekúthē.

Mile, Vker'kv.

Military, Suletáwv-ómē.

Milk, Epéssē. Péssē.

Milk, (cow's) Wákv-pes'sē.

Milk-bag, Epéssē.

Milk-cow, Wakv-en-kafkv.

\section{MIL}

Milk-pan, Wakv-pes'sē-palv'knv. Milk-strainer, Wakvpes'sē-senculíkv.

Milk,(sweet) Wakv-péssē-cv'mpē. Milk-weed, Hv'tkē-káfkv.

to Milk, Enkófetv. Cullícetv.

Milky, Kvsóhē. Kvsókē.

Mill, Sem-fulótkv.

Miller, Emfulótv.

a Million, Cúkpē-rákko-vculē.

to Mimmic, Svháyetv.

to Mind, Vker'rícetv.

Mind, Vkerríckv. Puyvfékcv.

Mindful, Vfek-cákhē. Vkerrícēhērē. Vketécē.

Mine, (my own) Cvnákē. Vn. $\mathrm{Vm}$.

Mine, (of metal) En-kor'kv.

to Mingle, Sētekcv'netv.

Minister, Erkenv'kv.

to Minister to, Vtótketv. Vtot.

hóketv. Vtotkv'ketv.

Mink, Es'kv.

Minnow, Rvkpv'wucē.

Minor, Upvklv'tkē.

Minstrels, Wahokv'lkē.

Mint, Kofóckv.

Mint, (horse) Kofóckv-rákko.

Minute, (6o seconds) Hv'sēvkēr'kucē.

Minúte, Vhērícet. Lopótkv.

Miracle, Nak-cēlákv-sēhonéckv.

Mire, Ak-lowáhē.

Mirror, Stak-héckv.

Mirthful, Ok-hácē-máhē.

Miry, Aksumóhē.

to Make miserable, Kusapécetv.

to Miss, Ehósetv. Emv'ttetv.

Mississippi River, Ué-okófkē.

to Mistake, Ehósetv.

Missionary, Nakcókv-mvháyv.

Mist, Oskē-wáskucē. Hèfkē.

Hopérē.

Mistletoe, Tóh-elleko. Eto-ēleko. 


\section{MIS}

Misty, Oskē-wáskucē.

Mitten, Sten'kē-somēcáckv. Esten'kvtéhkv.

to Mix, Cvlv'petv. Afétv.

Mixed, (a little) Svpv'kusè.

Mixture, Cvlv'pkv. A'fkē.

Moccasin, Estel'lepíkv.

Moccasin-snake, Ué-ak-cétto.

to Mock, Sv-háyetv. Hayáketv.

Mocking-bird, Fus-vháyetv. Fussvpáyv.

Moderate, Lekúthē.

Modern, Mómē-mv'ts.

Modest, Yatúcē.

Modest, Fek-hv'mkekot. V'lse.

Moist, Otóhē.

to Moisten, Otóhetv.

Molasses, Nehē-cv'mpē.

Mole, Sv'kv. Táko.

Monday, Mv'ntē.

Money, Cv to-kunáwv.

Money-changers, Es-yopóskv'lkē.

Moneyless, En-crtokunv'p-séko.

Money-purse, Cvto-kunvp-hutē.

Monied, En-cvtokunáwē.

Monkey, Wótko-éstē.

Monstrous, Rak'ketv'ts.

Month, Hvs'è-hv'mken.

Monthly, Hvsē-alik-omv'lkv .

Moor, Hvréssè.

Moon, (new) Hvréssē-mucvsē.

Moon, (full) Hvréssē-pvlóksē.

Moon, (eclipsed) Hvréssē-tepóyet.

Moon-light, Hvréssē-hiyáyvkē.

Morality, Fvtc'v-áretv.

Moral-law, Vhákv-pálat.

More, Semúntvlen. Hvtvlákat.

More, Hv'tvm. Hoyánen.

More than all,Semúntvlen. Omv'lkv-res-ēmuntàlat.

Moreover, Oh-hvtvláken. Ohhvtvlákat.

Morning, Hvthiyv'tkē. Hiyatíkē. Hiyv'tkē.

\section{MOR}

Morose, Eléskē-ómet.

Murtal, E'lē-táyet.

a Mortar, Kéco.

Mortar, (mud) Fak'kē-cvlv'pkē.

Mortification, Lékwē-elēcr.

Mosquito, Okēyēhá.

Mosquito-bar, Okēyēhá-sentv'c$\mathrm{kv}$.

Moss, Vtóklopē. Assúnwv. Vsímwv.

Mossy, Assúnwē.Vsímwē.

Mote, Eto-kv'ckucē.

Moth, (worm, on hides) Sokéhtv。 Mother, Et'skē.

to Moulder, Lékwetv. Hopánetv.

Mouldy, Paktóksē.

Mound, Ekvn-hv'lwucē. Rv'nē.

Mount, Rv'nē.

Mountain, Ekvn-hv'lwē. Rv'nē: Mountainous, Cefáhlē.

Mountains, Ekvnhulháwv.

Mountains, (on the) Cefahlófv.

Mountain-lizzard, Tvksvpúlkv.

to Mourn, Hvkíhóketv. Wahóketv. Oy'etv. Pohyv'ketv.

Mourner, Wahókv. Oyē.

Mournful, Royánkucè.

Mourning, Wahóket. Pohyv'* ketv.

Mouse, Ces'sē.

Mouth, Cúkwv.

Mouth, (of stream) Hv'tcē-vkáckat.

Mouth, (or brim) Fulówv.

Mouth, (narrow) Puehúsē.

Movable, Akúekē.

to Move, Akuéketv.

to Move, v. c., Akueyícetv.

to Move from, Akuéyetv.

Mover, Conéckv.

to Mow, Wocótetv.

Much more, Mahvkau.

Much, Sulécē. Vnv'comē. Súlke. 


\section{MUTD}

Mud, Ak-lowáhetv.

Muddy, Ak-lowáhē.

Muddy water, Ue-okófkē. Uesvholwákē.

Mud-hole, Ak-háukē. Ok-lowákē.

Mug, Sésketv.

Mulatto, Mulátv.

Mulberry, Kè.

Mulberry-tree, Kè-v'pē.

Mule, Corak'ko-píhkv.

Mullen, Hec'è-vhákē.

Muller, Tvkvwv'.

to Multiply, Tohkv'letv. Tepokv'cetv. Ohhvtvlíyetv. Honvpsetv.

Multitude, Estē-sulsókē-máhet.

Mumps, Hasv'f keta.

Murderer, Estē-elécv.

Murderous, Es'tē-elécē.

Muscatine, Colóswv.

Muscle, En'a-cvréhē.

Muscle-shells, Rolv'hpv. Fulvh'pv.

Mush, Af'kē.

Mush-room, Pv'tu.

Mushy, Cvlv'kmē.

Musical, Yvhíkē. Es-yvhíketv.

Musk of skunk, Hokcéwv.

Musk-melon, Frmécv.

Muskovy-duck, Fúco-sulē.

Musk-rat, Okcótkv.

Muslin, Mv'slē. Totkv-fúlkv.

Mustard, Mv'sta.

Must stand, Svpvklvránet-ómes.

Musty, Lékwē-ómē.

Mute, Opunáyeko.

to Mutter, Atvhíketv.

Mutton, Yvpefíkv-vpéswv.

My or Mine, Vn. Vmē. Crnákē. Vn. Vm.

Myrrh, Helúk-fvmécv.

Myself, Vn-tv'lkē. Vntvlket.

Mysterious, Estómahēe.

Mysteries, Enákē-ehkákat.
NAF

Mystery, Nakē-éhkat.

My wrong, Nak-cvnaorícat.

\section{N.}

Naftalım, (the town) Naftelem.

Nag, Corak'kucē.

Nail, Vcópv.

Nail, (of finger) Enkē-kosv'sowv.

to Nail. Svráhetv. Svráyetv.

Sv'retv.

Naked, Natv'lkē. Vtcékon.

Name, Hocéfkv.

to Name, Hocéfetv.

to Name after, Vho-cēfetv.

Named for, Ahocéf kē.

Nameless, Hocéf-séko.

to Nap, Núcetv.

Napkin, Hvsvtéckv.

to Narrate, Punáyetv.

Narrow, Con'tkusē.

Narrow-mouthed, Púehē.

Nasty, Sv-holwáke.

Nation, Tvlófv.

National, Trlwav'lkē. Emvkerric'kvt. Vnv'comv.

Nations, Tvlwav'lkē.

Native, Eme-tvlhv'mkē.

Naught, Mónks.

Nauseous, Este-ewíce.

Naval, UTehv'tkē-esfulv'lke.

Navel, Hocéwv.

Navigable, Uéwv-tíke-tetáyes.

to Navigate, Se-enfiyv'tketv.

Near, Tewólē. Témpē. Vwólē.

Vnákv.

to be Near, Vnakúecetv. Awo-

lícetv.

Neat, Hasv'tkē.

Necessary, Momē-tetás.

Necessitous, Eyáces.

Neck, Nok'wv.

Neck-lace. En-nocetv.

to have Need of, Eyácetv.

Needful, Eyáces. 
NEE

Needle, Esropót'tv. Kvhákkucē. Needle-case, Esropót'tr'vteh'kv. Needless, Eyáceko.

Need not, Estónkos.

Needy, Esteméres.

to Neglect, Nak-celáyekot.

to Neglect, Wíketv celáyē-táyet.

Neglectful, Nak-afvstemáheks.

Negligent, Nak-afvstemáheks.

to Neigh, Pih'ketv.

Neighbor, Vwólv. Awolícv.

Tenakúecv.

Neighboring, Vnákv.

Neighborly, Ten-yvmvsv'kē. Ten-vkúecvkē.

Negro, Este-lv': tē.

Neither, Mónkat.

Nephew, (of a man) Hopúewv.

Nephew, (of a woman) Húswucē.

Nervous, Fēkéketv.

Nest, Poknv'kv.

Net, Hóyv.

Nettle, Stvtvlákv.

Nettle (bull) Stvtvlákv-rak'ko.

Nettle-rash, Fotv'kletv-ómē.

Neuiral, Estómis-en-yvmv'set.

Never, Estófis.

Nevertheless, Momē-estómis.

$\mathrm{N}: \mathrm{w}, \mathrm{Múcvsē.}$

News, Opunvk'v-múcrsē. Opunv'kvsán.

News-carrier, Opunvk'v-sárv.

Newspaper, Cokv-tv'lemē.

New Testament, Setemfv'tcetv múcrsē.

New Testament, Nakcókv-mucvsè.

Next, Svhokkólat. Hv'tvm. Rem.

Next day, Páksē.

Next month, Hv'sē-hvm'kē.

Next summer, Méskë-hvmkè.

Nexi week, Net'tv-vcákucē-hv'mkē.

Next year, Orólopē-múcrsē.
NIC

Nice, Hēnros. Es-hēn'rusen.

to Nibble, Tor'ketv.

Niece, (of a man) Hv'kpvtē.

Niece, (of a woman) Húswucē.

Niggardly, Nak-en-cákē.

Night, Nerē.

Night-cap, Nérē-kapvtókv.

Night-clothes, Nérë-vt'cetv.

Nimble, Lowáke.

Nine, Ostvpáken.

Nineteen, Pálen-ostvpóhkaken.

Nineteenth, Es'palen-ostvpóhkaken.

Ninety, Palē-ostvpáken.

Ninth, Es-ostoh-pákat.

to Nip, Tècétketv.

Nippers, Sáwekélkv.

N`tre, Ok'cvn-rák'ko.

Nits, Ec'kvp-ner'kv.

No, nay, not, Kus. Mónkos. Hekúst.

Noble, Hērē.

to Nod, Nekótetv.

to make a Noise, Háketv.

Noise, Esstóke. Hákē. Ohonv'kv.

Noisy, Esiokemáhē. Oh-onv'kē. to be Noisy, Sestókemáhetv.

Nominal. Hocéfkv-tv'lken.

None, Sáhsekos. Seks. Séko. Sépeko. Nv'pvt.

None, Sekóst, Sek'scv.

Nune at all, Sásekos.

No more, Svnv'comv.

No one, Nv'pv. Nv'pvt.

Nonsensical, Hoporen'eko-ómet.

Noon, Fv'tcv-líke. Nettv-nvrkv'pv.

Nor, Mónkat.

North, Húnērá.

Nose, Yúpo

Nose-bleeding, Yupo-cátv .

Nose-ring, Yúpo-vtárkv.

Nostril, Yupo-haúken. 


\section{NOT}

Not, it is not, Kust. Hekúst. Toko.

Notable, Kerk-hērē.

Not at all, Mónkotós.

Not many, Nvcomeko.

Not a few, A-nvcómeko.

Not grown, Máhoks.

Notch, Lvk'hē.

to Notch together, Tetéhetv.

to Notch up, Toh-cv'sketv. Ke-

lēhécetv.

Notched, Keléhē.

to Note, Sátetv.

Not have, Oricaketv.

Nothing, Nak-tóko.

Notorious, Ker'kusē.

Not so, Monkos. Monks. Monkvtos.

Not venturing, En-kvsv'mkusē.

Notwithstanding, Momē-stómis.

Novel, Múcuse.

November, (frost month) Ehólē.

Now, Hv'tē. Múcv. Tókvs.

Hiyómen. Hiyómat.

Now-a-days, Múcv-net'tv.

Nowhere, Es'tv-tóko.

Noxious, Nokkícē-táyēs.

Numb, Pvsv'tkē.

Number, Ma-honkv'tkv.

to be Numbered with us, Es-epuhonképetv.

Numerous, Nvcómē-máhē.

Nurse, Hopuéwucē-ahecícv.

to Nurse, Hopúe-ahecícetv.

Nut, Nak-lókcē.

Nut, (of Lotus) Kvtóhwv.

Nut-meg, Esfvmēcíckv.

Nuyaka-town, Nuyaka-tvlofv.

\section{0.}

Oh! Aéha! Aéla!

Oak, (red) Lókcvpē.

Oak, (black) Lókcvpē-lv'stē.

Oak, (black-ja.ck) Sécv.

\section{OAK}

Oak, (chestnut) Meskólwv.

Oak, (over cup) Kvlv'pē.

Oak, (post) Cóskv.

Oak, (Spanish) Tokvmáhv.

Oak, (water) Meskólwv.

Oak, (white) Kv'lv.

Oak, (water tree) Méskol-vpē.

Oak, (live) Lókcvpē-lánē.

Oak-bark, Lókcvpē-hvrpē.

Oaken, Lókcvpē-hákv.

Oar, Eskófkv.

Oath, Opunv'kv-yek'cē.

Enhúerv. Temfv'tcetv.

Oats, Corak'ko-ēn-hom'petv.

Obedience, Eyásketv.

Obedient, Eyáskē.

to Obey, Apohícetv. Afv'stetv.

Obdurate, Ekv-yékcē.

to Obey, Mapohícetv.

Objection, Trc'kē.

to Oblige, Yvmv'setv.

Obliged, Yvmv'sē.

Oblıging, En-yvmv'sē.

Obscure, INer'kē-máheko. Mos'hon-kerremáhekot.

to Observe, Vketécetv.

Observer, Oh-hécv.

Obsolete, Wihókvtē. Semvníckv-séko.

to Obtain, Heckuécetv. Enhec'ketv.

Occult, Arvnákē.

Ocean, Ue-hv'tkv-rákko.

October, Oto-wáskv-rak'ko.

Oderous, Frmécē.

Odious, En-homéckē.

Of, E. En. Em.

Off, A. (prefixed to a word.)

to Offend, Mv'ttecícetv. Vnrv'petv.

Offender, Vnvttécv.

Offenders, Vnvttecv'íkē.

Offensive, Vnrapuécē.

Offensive-smell, Fvm'pē. 


\section{$\mathrm{OFF}$}

to Offer, Svt'tetv. Em-wíyetv.

to Offer to, Awíyetv.

to Offer sacrifice, Oh-nekricetv.

Offering, Wíyetv.

Office, En-huéretv-rak'kē.

Officer, Sē-vpáyv.

Officious, Nak-celákv-vnóksē.

Offspring, Er-hocátskē. Er-honv'psè.

Often, Tewólen. Tewólusen.

Oft-tımes, Tewólen. Tewólusen. Mahekv.

Oil. (lard, etc.) Nēhá.

Oil-cloth, Totkvfv'lkv-nēhē.

Oily, Nēhē. Nehá-v'lkē.

Ointment, Nēhē. Afékv.

Old people, Estē-vculvkē.

Old, (male) Vculē.

Old, (female) Hóktviè.

to be Old, Vculetv.

Old cow, Wákv-hók-tv'lwv.

Old custom, Hofunē-nakv fv'stetv.

Old, (as of cane) Tówē.

Old things, Léskē. Ahássē.

Old time talk, Kúlwv̄.

to talk-Old time, Kúlwetv.

Old age, (of a woman) Hoktv'lkv.

Old field, Cvpo-sákwè.

Old town, Tvlla-has'sē.

Old witch, Hoktv'l-kúlowv.

Old woman, Hóktvlē. Hoktv'lwv.

Olive, Olefé.

Omen, Hénkis-tv'ntos.

Omnipotence, Yek'cetv-omvlécēe.

Omnipresence, Estómis-ar'ttv.

Omniscience, Nak-omv'lkv-kérē.

On, Oh. On'vpvn.

On account of, Svráhkv. Vráhkv.

On each side, Em-pv'lset. Tempálusen.

Once, Vhrm'kv.

One, Hvm'ken.

One hundred, Cúkpē-hv'mken.

One only, Hv'mkusē.

\section{ONI}

Onion, Ta-fvm'pē.

Onion seed, Ta-fv'mpē-ēner'kv.

Only, Tv'lkusen. Tr'lkē.

to be Only they, Tv'lketv.

On me, Vcóh.

Open, Rvm'kè.

to be Open, Wénketv.

to Open, Hauwécetv.

to Open, (a box, book, etc.) Enrámetv.

Open-mouthed, Hauwv'klē.

to Open the mouth, Hauwv'klécetv.

to Open the eyes, Arvmrícetv. Rènáyetv.

to open the eyes wide, Cêleléketv.

Openly, Hec'kē.

Opium, Es-nucicéckv.

Opodeldoc, Hvsv'fkē-esíkv.

Opossom, Súkha-hv'tkē.

Opponent, Rápv.

Opportunity, Tektv'nkē.

to Oppose, Vnrv'petv. Ten-rápetv.

Opposite, V'nrvpē. En-fv'tcvn. Rápē.

to Oppress, Svlvfkúecetv. Ma wēténetv.

Oppression, Svlv'f ket.

Oppressive, Svlv'fkē. Acukoyés$\mathrm{kv}$.

Opulent, Nak-ócet.

Or, Mónkat. Tut.

Oral, Es-opunáyē.

Orange, Yvláhv.

Orange, (sweet) Yvláhv-cv'mpē. Yvláhv.

Orator, Opunáyv.

to Ordain, Em-wíketv-háyetv.

in Order, Temvpv'lwv.

Ordinances, Mellv'kvtē.

Ordination, Em-wíketv-háyetv.

Original, En-hvtecéskv.

Ornarnent, Sen-ēhíckv. 
ORN

to Ornament, Nēhēcécetv.

Ornamental, Es-nēhíckv.

Orphan, Etskë-mel'lē. Etskv'lkēsēkó.

Orthodox, Punvk-fv'tcv. Afvtcr-táye.

Orthodoxy, Punvk'v-mehénwv.

Other, Vpv'lwv. Eti.

the Other one, Hv'mkat.

Other side, Palhv'mke. pálv.

Otherwise, Momen-omát.

Otter, Osv'nnv.

Otter-skin, Osvn'nv-hvr'pē.

Ounce, Vtar'kucē.

Ours, Púnakē.

Out of joint, Rókkē.

Out in the woods, Lvpv'tke.

Out of, Asóssē. Sossē.

Outrageous, Akvsv'mkusē.

Out of the way, Vfvlékne.

Out of sight, Vrvnákē.

Outside, Topv'rv. Topv'rvonv'pv.

to get Out of sight, Vrvnáketv.

Outwardly, Onv'pv.

Oval, Polóksē.

Oven, Lócv-tvpéksē. Ellē-ocá. Leócv.

Oven-lid, Lócv-oh-rvn'kv .

Over a fence, etc., Palhv'mkē.

Overcoat, Kápv-rákko.

Over a stream, Tvpála.

Over and above, Er-ohvtvlv'ket.

Over again, Svnv'comv. Tóh.

to Overcome, Ránetv. Muntáletv.

to Overturn, En-cēktulcécetv.

to Overgrow, Rak'kē-máhē-háketv.

to Overlay, Oh-pv'cetv. Oh-wakétv.

Overseer, Afástv. Sēvpáyv. to Overset, En-cēktulcécetv.

\section{OVE}

to Overset, Hvkkv'n-cellēpétketv.

to Overshadow, Ráwetv.

to Overtake, Cvk'ketv.

to Overtbrow, Cektultécetv.

to Overtırn, Hvkkvn-cellē-pétketv.

Owl, O'pv.

Owl, (horned) Estek'enē.

Owl, (prairie) O'pv-wákv.

Owl, (screech) Efv'lv.

to Own, Enákē-háyetv.

Owners, Ocv'lke.

Ox, Wakv-vtot'kv.

Ox-bow, Wakv-en-cakvtv'ksēe

Ox-chain, Wakv-cv'to-tēlácv.

Ox-horn, Wakv-enyv'pé.

Ox-yoke, Wakv-encakvtvksē.

Móh-tvkhákv. Nók-ohwákv.

Oyster, Huérekó. Ocákvlv.

\section{P.}

to Pace, Let'kē-hēretv .

Pacer, Yvkv'pē-lopícv. hèra.

Pacific, Yvmv'sē.

to Pack, (hard) Vwvnhécetv.

to Pack, (in basket) Vtc'hetv.

to Pack, (on horse) Sápolícetv.

Packed hard, Vwv'nhē.

to be Packed hard, Vwr'nhetv.

Pack-saddle. Tolekv'ksē.

Paddle, Eskáfkv.

to Paddle, Káfetv.

Pad-lock, Svlícv. Svlíkv.

Page, Es-wv'kè. Se-tentv'ckē.

Pail, Ue-escaúkv. Vcr'nkv.

Pain, Tíyē. Ena-nok'kēe. Nókkē. to be Pained, Nokhóketv.

Painful, Nokhóke. Nokhókan.

Painful, (very) Nókketá.

Painless, Nokhókekót.

Pains, Tikóyē.

Paint brush, Eshotópetv.

to Paint, Svn-cáletv. Hotópetv.

Espv'cetv. 


\section{PAI}

Paint, Es-sikíkv.

Painter, Cuko-svholópv.

Pair, Tem-pv'lsē.

Palate, Tuláswúcē.

Pale, Hv'twè.

Pale-green, Hv'twē-lánē.

Palings, Tvhópkē-fvsóhē.

Pallet, Tópucē.

Palm of hand, Enk-ófv.

Palpable, Kérkurē-tetáyē.

Palpitation of heart, Efékē-tásketv. Fēkē-kákat.

Palsy, Fēkéketv:

Pan, Pvlv'knv.

Pancake, Apvtv'kv.

Panegyric, Akvsv'metv.

to Pant, Hesáketv-ēlet. Fek-tácketv.

Pants or Pantaloons, Vtekpíkv.

Pantaloons, Hvfekpikv.

Panther, Kátcv.

Papaw, Or'ko.

Paper, Nakcókv.

Parable, Svhopákv. Opunv'kvsvhopákv.

a Paraque:, or Parrot, Pvcē-lánē.

Parasol, Séko-hvpetic'kucē. Vpettíckucē.

to Parch with, Svpvsetv.

Parched meal, Apv'skè.

to Pardon, Emérretv.

to Pare, Kvlv'fetv.

Paregoric, Es-nucic'kucē.

Parents, Etskv'lkē. Purkv'lkē.

Parrot, or Paraquet, Pv'cē-lánē.

Parsimonious, Nak-encákē.

a Part, Apv'lwusē.

to Part, (from at will) Kvpv'ketv.

to Part, (per force) v.c., Kvpiyecícetv.

to Part, (from each other) Tenkvpv'ketv.

to Part with, Sen-kvpv'ketv.

Parted, Tekvpv'ke.

\section{PAR}

Partial, En-cákē. Etem-êtúecē.

Parting, 'Ténkvpv'ket.

Partuition, Sícetv.

Partner, Tohkálv.

Partnership, Toh-káletv.

Partridge, Kowíkē.

to Pass, Hoyánetv.

to Pass away, Sum'ketv.

to Pass each other, Sētē-yopósketv.

to Pass from. Ahoyv'netv.

to Pass over, Tíketv.

Passable, Huyanē-táyē.

Passionate, Vyakhv'mkè.

Passion-flower, Opv'kv.

Pass over, Oh-hoyv'nkv.

to Pass-over, Oh-hoyv'netv.

Past, Hoyánvtes. Hoyánē.

Past, (already,) Hoyvnéps.

Paste, Kulówv. Svlokpíckv.

to Paste, Svlókpetv.

Pasteboard, Cokv-tvkv'cwē.

Pastern-joint, Lak'sv-ónvpv.

Pastor, E'rkē-nvk'kv.

Pasture, Nanopkv. Apuékv-en-

ful'letv.

to Pat, Estē-yvmv'setv.

Patch, Mvlíkv. Mvlúmhv.

to Patch, Ma-lumhícetv.

Pate, Ek'v-ónvpv.

Pa hr, Nen'nē.

Pathless, Nen'nē-sekó.

Patience, Meháketv. Momis-

kómē.

Patient, Em-eháketv.

to be Patient, Mómis-kómetv.

to be Patient, Em-Eháketv.

Patriarch, En-homáhtv.

Pattern, Vhopákv.

Paul, (the Apostle) Pal.

Pavement, Cvto-p'vtihocvte.

Paw, Ellē-hómv.

to Paw, Ellē-hómv-svkásetv .

Pay, Féketv. 


\section{PAY}

to Pay, Féketv.

to Pay a debt, Ahúerícetv.

- Payment, Féketv. Sētem·féketv. Pea, Tvláko.

Pea, (garden bush) Tvláko-cápkucē.

Pea, (garden) Tvláko-pákucē.

Peace, Her'kv.

to hold Peace, Cryáyetv.

Peaceable, Her'kè.

to make Peace, Ten-hérkēpúe. cetv. Hérkv-háyetv.

Peace-maker, Herkv-háyv.

Peach, Pvkánv.

Peach-tree, Pvkán-v'pē.

Peacock, Pen-hv'cē-hēra.

Pea-fowl, Pen-holócv.

Peak, Ekvn-hv'lwē-onv'pv.

Pear, Eco-em-pvkánv.

Pearls, Nakè-vcákat.

Pear-tree, Éco-em-pvkán-v'pē.

Pebble, Cvto-crsákwē.

Pecan, Oce-cápkucē. Ocē-tvkác$\mathrm{kv}$.

Pecan-tree, Oce-cápkē-mv'pē.

Peck, Svker'kv-nvr'kvp-en-nvr' kvpv.

Pedlar, Nak-wíyucē.

to Peel. Fayetv. Cvpáketv.

Peevish, Fék-hēreko.

Pelican, Nok-súkcv.

Pen, Es-hótcíckv. Ess-cókv .

Pen, (gold) Cvto-kunv'plánē-eshótcíckv.

Pen, (steel) Cvto-tot'kv-eshótcíckv.

Pencil, Sen-sátkv. Essátkv.

Pencil, (leád) Rè-eshótcíckv. Èscókly.

Pencil,(slate)Cvto-lv'stē-eshótcíckv.

to Penetrate, Oh'ropot'tetv.

to Penetrate,(by stabbing) Pakv'fetv.

\section{PEN}

Penitence, E-fékē-nok'kē.

Penitent, E-fékē-nokkícē.

Pen-knife, Sláfkucē. Esláflkucē.

Penniless, Estè-mer'kusēe.

Penny, Nvr'kvpucē.

Pensive, Fèk-hun'nē.

Pentecost, Pentēkás.

Penurious, Nák encákē.

People, Es'tē. Estv'lkē.

Pepper, Hómo.

Pepper, (black) Hómucē.

Pepper-box, Homo-sētéhkv.

Pepper, (red) Hómo-cátē.

Pepper-grass, Tukáskénv.

Peppermint, Kofóckv.

Peradventure, Mómē-wítes.

Perch, Svntvlv'kwv.

Perch, (small) Rvkpv'swv.

Perchance, Mómē wites.

Percussion-caps, Cv'to-lánucē.

Perfect, Yvkpókusē. Em-ētētákvs.

to Perfect, Hērē-háyetv.

to be Perfect, Hvsvtketv.

Perfectly, Es-yukpókusē.

Perforated, Téropottícē.

to Perform, Celáyetv. Momécetv.

to Perform on, Oh-wíkekv.

Perhaps, Mómē-wítes.

Perhaps so, Mómis-ómēs.

to Perish, (from pain) Sumecícetv.

Perishable, Elē-táyē.

Permanent, Tektv'nkat. En-

líketv-máhē.

to Permit, E-tektvnécetv.

Pernicious, Naor'ke.

Perpendicular, Fv'tcv-huérē.

Perpendicular, Lvpúntkusē.

Perpetual, Ayē-múnkē.

to Persecute, As'sécetv. Assécketv.

Persecution, Asec'kv-táten.

Perseverance, Ayek'cetv. 


\section{PER}

to Persevere, Acayécetv. Vyek'cetv.

Persimmon, Svt'tv.

Person, Es'tē.

Persons, Estv'lke.

Perspiration, Em-méskē.

to Persuade, Mahé-rakkuécetv.

to Persuade, Lopvkúecetv.

Pert, Fēk-hvm'kē.

Perverse, Yvnahē. Yēnaháckē. to be Perverse, Yv'netv.

Pestle Kēcrp'pē.

Pet. Sem-ák-hopv'nkucen.

to Patrify, Cvto-háketv.

Pettish, Hokósē.

Pettycoat, Ofv-wákv.

Pewter, Car'kvs-hv'tke.

Phylactery, Tvkhv'ketv.

Phlegm, Lepvk'fē.

Physic, Hēléswv.

Physician, Hēles-háyv. Vlek'cv.

Piazza, Cuko-vpet'tē. Sóh-vpéttv.

Picayune, Kvláksucē.

to Pick, (to gather) Mámetv.

to Pick, (as a rock) Sen-kor'etv.

to Pick about, Nanópetv.

to Pick up, Aēs'setv. Trk-es'setv. Ayócetv.

Picture, Nak-vhákē. Vhákē.

Pie, Semvtékē.

Piece, Tvck'usen.

Pieces, Wárkē.

Pieded, Lvkáhē.

to Pierce, Sēkēyetv.

to Pierce up to, Rés-vlícetv.

Piety, Hēretv. Mekusv'pkvn.

Pig, Suk'hvcē.

Pigeon, Pv'cē.

Pigs, Sukhvcv'lkē.

Pike, (a fish) Rvro-pvlókē.

Pile, (a heap) Hv'ppo. Copóksv. to Pile, Vtel'lóyetv.

Piled up, Copóksē.

\section{PIL}

Pilgrims, Cúnē-cv']kē.

Pill, (of medicine) Hēlés-cērē.

Pillar, Cukélle.

Pillow, Oyap'kv.

Pillow-case, Oyáp'kv-en-súkcv.

Pills, Helés-cērē-hócē.

Pilot, (on land) En-homáhtv.

Pilot, (on water) En-fiyátv.

Pimples, Fulóha.

Pin, Kvhak'kucē. Kvsásucē.

Pincers, Sawēkélkv.

to Pin h, Yek'letv.

Pin-cushion, Trhak'kucē-svcakkéckv.

Pine, Cúlē.

to Pine away, Oyokē-haketv.

Pink, (color) Cátē-ómē.

Pink, (flower) Pvkpvké-cátē-ómē.

Pink-root. Cúntv-hēléswv.

Pinnacle, Soh-vpéttv. Onv'pv.

Pint, Svkérkucē. Hálo-fyck kehvm'ken.

Pious, Hērē. Mekusápē.

Pipe, (to smoke) Hecēe-pv'kiwv.

Pistol, Trpóc'kucē.

Pit, (of the stomach) En-kvtvr'pv.

Pit, Kvn-súf kè.

Pitcher, Uewv-svcrn'kv. Pēc'v.

Pitch-fork, Cofún-yak'pē.

Piteous, E-mer'rusv'kè.

Pithy, Tok'wē.

Pitiful, E-mer'rusv'kē.

Pity, Mer'retv. Mérkv.

Place, (yard, etc.) Fet'tv.

Place, (in corner of square) Tvc'o. to Place, (as in a crevice) Asóketv.

to Place around, Afulótke-ócētv. to Place, Nvthofécetv. Lícetv.

to Place in, Atvkháyetv.

to Place, Ocáketv. Sēhóyetv.

to Place, Vpopúecetv.

Placed, Marvpv'tkē.

to Plague, Naorícetv. 


\section{PLA}

Plaguy, Naorícē.

Plain, Ker'kv-hērē. Kèr'kvhēn.

Plainly, Ker'kusē.

to Plait, Hotv'netv.

Plaited, Hotv'nke.

Plan, Eskerkúeckv.

Plane, (level) Ekv'n-tvpéksē.

Plane, (a tool) Estenépíckv.

to Pla e, Kvlv'fetv.

Planet, Kococúmpv-rak'kat.

Plank, Totopéksē. Eto-fókvtupéksē.

a Plant, Ahoc'kv.

to Plant, Ahoc'etv.

Planter, Ahócv.

Planted, Ahóckē.

Plaster, (blister) Stakvnéckv.

to Plaster, Alófetv.

Plastered, Alóf kē.

Plate, Palv'knv.

Plate (pewter or tin) Palv'knvhv'tke.

Platter, Palv'knv-tvpéksē.

to Play, Sáhkopánetv. Ah'kopánetv.

to Play down in water, $\mathrm{Ak}^{\prime}$-áhkopánetv.

to Play, (see-saw) Eten-crmes'setv.

to Play, (ball) Pokkécetv.

Play, Ak'hopv'nkv.

Play-thing, Sákhopv'nkv .

Pleading, (for one) Eyóposiketv Opunáyetv.

Pleasant, Hērē.

to Please, Yvmv'setv. Afvcēcícetv.

Pleasure, Afvcēcíckvn.

Plentiful, O'cē-hērē.

Pledge, Enhúerv.

Pleurisy, Env'cē-enok'kē.

Pleurisy-root, Env'cē-enok'ke-hēléswv.

Pliable, Kunhēcv'kē-táyēe.

\section{PLO}

to Plow, sin.. Cv piyécetv.

to Plow, pl., Cvpiyêcr'k'etv.

Plow, Cvpiyéckv.

Plower, Cvpiyécv.

Plow-handles, Cvpiyéckv-en-halv'tetv.

Plowman, Cvpiyécv.

Plow-share, Cvpiyéckv-encv'to.

Plow-stock, Cvpiyéckv-emv'pē.

to Pluck, (out) Ossícetv.

to Pluck up. Lémetv.

to Pluck, (corn) Mámetv.

to Plug, En-cēkótetv.

Plum wild, Pvkánvhē.

Plum, Prkánucē.

Plume, Táfv.

Plump, Polóksē.

Plum-tree, Pvkánv-cátucē-emvpē.

to Plunge, Ak'cēyícetv.

to Ply, Pvkorícetv.

Pneumonia, Opv'fkv-hopv'nk̄. Opv'f kv-ennókē.

Pocket, Suk'cr.

Pocket-book, Nakcókv-en-suk'cv .

Pocket-knife, Sláf kv.

Pod, E-hvr'pē.

Point, Yuk'sv.

to Point, Mélletv.

Poke-weed, Os'a.

Pole, Eto-cap'kē. Eto-nakóftē.

Pole, (of a boat) Estaúkv.

Pole cat, Kúnu.

Polite, Holwayéceko Afvc'kē. to Pollute, Holwahúecetv. Vholwayécetv.

Pollution, Vholwayéckv.

Pompous, Estokemáhē.

Pond, Akhv'ssē.

Pond-lily, Ue-ak-tv'phē.

Ponderous, Hon'nē.

Pony, Co-rak'kucē.

Pool, Ak-hvs'sucē.

Poor, Estemer'kē. Enkvsvpkē.

Estemérusē. Oyókē. 


\section{POP}

to Pop. (crack as a gun) Tvpócketv.

to Pop, (as wood in burning) Trpóhletv.

Puplar, Hecélwv.

Porch, Sóh-vpéttv.

Pork, Suk'hv-vpéswv.

Porringer, Sésketv.

Porter, Es-áyv.

Positive, Fvt'cv-hērē.

Possessions, E.ıakúeckv.

Possibly, Mómē-tetáyē.

Post, Cuk-el'lē. Yákpē.

Post-master, Cokv-tv'lvmē-pucásē.

Post-rider, Cokv-tv'lemē-sárv.

Pot, Leháyv-tvpéksē. Ellē-oca.

Pot, (earthen) Vrkv'swv. Natv'rkv.

Potato, (sweet) Ahá.

Potato, (Irish) Ahá-ceréhē.

Potato, (wild) Alún-ahá. Ahvlwv'nv.

Potato-slip, Aha-rv'fkv.

Pot-hook. Lehávv-tv péksē-fv'kv. Pot-lid, Leháyv-tvpéksē-orv'nkv. Potter, Vr'kvs háyv.

Pouch, (beaded) Suk'cv-hotc'è.

Pound, Vtar'kv.

to Pound, Pac'etv.

to Pound, (in a mortar) Hócetv.

to Pound at, Vcutóketv.

Pounded fine, Lopútkē.

Pounder, Kecv'ppē.

to Pour, Pvlátetr.

to Pour, (in) Vcv'netv. Oh-cv'netv.

to Pour, (in) Afvlécetv.

to Pour, (on) Oh-káletv. Ohpvlátetv.

to Pour upon us, Apohpalv'tetv.

to Pour out, Fih'netv. Fihnécetv.

Poured in, Afv'lē.

\section{POU}

to Pout, Ecáyetv.

Powder, Tohot'tuwv.

Powder-horn, Tohot'towv-hútē.

Power, Yek'cetv.

Powerful, Yékcē-máhē.

to Practice, Sē-em-mvháyetv.

Prairie, Hiyak'po.

Prairie-chicken, Kowíkē-rak'ko.

Prairie-fly, Róno.

Prairie on fire, Hopo'tkē.

Prairie-owl, Opv-wákv.

Praise, Akvs 'mkv. Kvsv'mkvn. Akvsv'murē.

to Praise, Akvsv'metv.

Praised, Akvsv'mkē.

to Prance, Tastv'ketv.

to Pray, Mekusv'petv.

to Pray over, Oh-mekusv'petv.

Prayer, Mekusvp'kv.

Prayerful, Mekusápē.

to Preach, Erkenv'ketv.

Preacher, Erkenv'kkv.

Precious, Nak-vcákē. Kusv'pkē.

Precipice, Akeléftē.

to Predestinate, Mélletv.

Predestination, Méllvtéhkvn.

Premature, Hvtemáhē.

to Prepare arrow-root, Kunte-aktáyetv.

to) Prepare, Etetakuécetv. Etētícetv.

Presbyterians, Oh-féskv'lkē. Pléspytev'lkē.

Present, Hiyómat. Hv'tē-vwólē. to Present, Em-wíyetv.

Presently, Lv'pkusēe. Hvtē-vwólē. to Preserve, Vcayécetv.

Preserver, Epufástv.

President, En-rákrvk'v.

to Press, Wèten'etv.

Presumptuous, Ekvsv'mē.

to Pretend, Esah'yetv.

Pretty, Hērusē.

Prevent, Sen-tv'cketv. 


\section{PRE}

Previous, En-homáhtē.

Price, Rafkv. Ráhkv.

to Prick, Cef'ketv.

Prickly-ash, Tokvsap'pv.

Prickly-heat, Hvs'so-estak'kē.

Prickly-pear, Tvlrak'ko. Tvráko.

Pride, Ekvsv'mkv.

Priest, Plest. Erkēnv'kkv .

Priests, Oh-nekricv'lkē. Plestv'lkè.

Prime, Mrkvteh'kusē.

Principal, Enhomáhtē-máhat:

Prints, Enhótcv. Svráhkvten.

to Print, En-colópetv.

Printer, Cókv-saholópv.

Prior, En-homáhtē.

Prison, Cúko-yek'cv.

Prisoner, Svlv'fkē. Svlv'fkuehócē.

Private, Eh'kusē.

Privilege, Eme-tektv'nket.

to Prize up the roots, Cvpenetv.

Prized up, Cvpénkē.

Probable, Mómē-wítes.

to Proclaim, Rotícetv. Opunáyetr.

Proclamation, Opunáyéckv.

Prodigal, Yvmah'kē.

a Prodigal, Yvmáhkúecv.

Profane, Estē-tahíkē.

to Profane, Ahopánetv.

Profane person, Estē-tahikv.

to Profess, Akvsv'metv.

Profit, Em-vnicē. En-lopicē.

to be Profitable, Honvpsécetv.

Profligate, Moskómekot.

Projecting, Fv'nkē.

Prolix, Afulótkē. Opunáyē.

to Promise, Em-akvsv'metv.

to Promise, Nakē-momecáresmáketv.

Prompt, Em-etētákē.

Prone, Oh-háyē.

Prong, Yak'pē.

\section{PRO}

to Prop up, Nēréketv.

to Prop on, Oh-nēréketv.

to Propagate, Rvtícetv.

to Propel, Etówetv. Etoh'ketv.

Proper, Fvt'cv-hērē.

Property, Apoékv.

to Prophecy, Owáletv.

Prophet. Owálv.

Propitiation, Em-fv'tcetv.

Proselyte, Akvsv'mv-huéckē.

Prospect, Ahécka.

Prosperous, Honv'psē-hērē.

Prostrate, Lúmhē.

Proud, Ekv-sv'metv.

to Prove, Oh-fvtcécetv.

to Provide, Vtéhetv. Hērícetv.

Provided, Mómē-tetáyen-ómet.

Providence, Epu-fvnkákv.

Provisions, Ehólwv.

to Provoke, Ellē-sēcécetv.

Prudence, Hoporénkv. Nak-kerretv.

Prudent, Vketécē. Emv'kerrickvken.

to Pry, (with hand spike) Kvpēletv.

Psalm or hymn, Es-akvsv'mkv. Esyvhíketv. Akvsv'metv.

Psalmist, Akvsámv.

Public, Tv'lemē. V'lkan.

Publican, Cvtókunáwv-vtelóyv.

Pudding, A'fkē.

to Puke, Awótetv.

to Pull, Hvlátetv.

to Pull away from, En-rēcv'pketv.

to Pull down from, Alēkv'fetv. Alētv'fetv.

to Pull down from, v. c., Alētvflécetv.

to Pull f om, Ahvlv'tetv.

to Pull out, Ak-ossícetv. Réketv.

to Pull out hair, Lémetv.

to Pull up, Ossícetv. Téfetv.

Pulse, Fēkē-temtékucē. 


\section{PUM}

Pumpkin, Cv'sē.

Punch, (a tool) Es-rulv'ketv.

to Punch, Ref'ketv.

Punctual, Hēlv'pkē.

to Punish, Stemerícetv.

Punishment, Estēmer'kv。

Puny, Púlsē.

Pupil, Cókv-hēcr.

Puppy Efúcē.

to- Purchase, Nésetv.

Pure, Hvsv'tke.

to be Pure, Hvsv'tketv.

Purgative, Eshóyvnéckv.

a Purge, Eshóyvnéckv.

to Purge, Es-hoyv'netv. yvnécícetv.

Purification, Hvsvtécekv.

Purple, Catē-ómē.

to Purloin, Vkonvháketv. Vkonv'hetv.

Purse, Cvtókunv'p-vteh'kv.

Purse-proud, En-cvto-ku-hútē-ésekvsámat.

Purse-string, Cvtókunv'p-vteh'kvfv'kv.

Purslane, Pv'sle.

to Pursue, As'setv.

to Pursue, (softly) Ayop'ketv.

to Pursue, (with) Sásetv. Es'as'setv.

to Push, Ahēpv'ketv.

to Push to or upon, Oh-hēpv'ketv.

to Push a boat, Táwetv.

to Put, O'cetv.

to Put across, Svwëlépetv.

to Put across, Tohtíkē-ócetv.

to Put around, Afulótkē-ócetv.

to Put away, Etímv-ócetv.

to Put back, Pv'lkè-ócetv.

to Put before, Ehómv-ócetv.

to Put behind, Eyúpv-ócetv.

to Put beside, Mvtvkhákē-ócetv. to Put between, Tenráwv-ócetv.

\section{PUT}

to Put in, Aktéhetv. Vcânetv.

to Put in, Ak-káyetv. Ak-tícetv.

to Put in a crack, Vsúketv.

to Put into, Piketv. Apíketv.

to Put near, Vnákv-ócetv'.

to Put off, (delay) Vtétety. Vkáyetv.

to Put on, (as hands) Oh wakhókícetv.

to Put on clothes, Vtcécetv. Vt'cēty.

to Put out, (as fire) Vslécetv.

to Put on, O'h-káyetv. Oh-lícetv. to Put on one's head, Kapvtóyetv.

to Put on a hat; Katvpóyetv.

to Put out, Poretv. Aslécetv. Sossícētv.

to Put down, Svlícetv. Svlumhícetv.

to Put over, Oh-káyetv. - Ohránetv. Oh-pvtcetv.

to Put to, Alih'cetv. Alúmhetv.

to Put upon, Oh'ócetv.

to Put up, Ossícetv. Tefétv. Apíketv.

to Put through, Ropottícetv.

to Put together, Astvpáyetv.

to Put under, Ak-píketv. Ellécv. céyetv.

Putrid, Ahopv'nkē.

Putty, Kolówv.

Quail, Kowíkē.

to Quake, Tekóketv.

ta Qualify, Etetákuécetv.

to Quarrel, Tvhíketv. Etehánetv. Quarrel, Etehánkv.

Quarrelsoine, Tvhíkē-máhē.

Quarry, Cvto-enkor'kv.

Quart, Halo-fv'ckē-hokkólen.

Quarter, En-nvrkv'p-ren-nvrkv'。 pv.

to Quarter, Tewóh-cohlícetv. 


\section{QUA}

Quarter dollar, Kvn-sátkv-hv'mken.

Queen, Mek'ko-hok'tē.

Queer, Em-vrahke.

to Quench, Vslécetv.

Question, Tem-póhetv. Apóhetv.

to be Quick, Lvpécetv

Quick, Lvp'kē.

Quickly, Lvpécē.

Quick-sand, Oktáhv-ak'súmóhē. Quiet, Cryíyákē. Yvmv'sē.

Quill, Táfv.

Quilt, Telúmhv. Cēyiyákē.

to Quilt, Telumhícetv.

Quince, Svtv-rak'ko-lánē.

Quinine, Hēles-hómo.

Quinsy, Nók-ráhē.

to Quit, Wíketv. Wiképetv.

Quite-another, Etúsē.

to Quiver, Miloméketv.

to Quote, Ellénetv.

\section{$\mathbf{R}$.}

Rabbi, Kērrá.

Rabbit, Cúfē.

Raccoon, Wótko.

to Race, Témáretv.

Racer, Létkv.

Race-horse, Corak'ko-sētemar'kv.

Raddish or beet, Yvlúnkv-cátē. or Lalúnkv-cátē.

Radiant, Holocē.

Raft, Akwvnv'kv.

Rafter, Cuko-en-tálv.

to Rage, Cvpv'k'ketv.

Ragged, Vtcv'kē-léskehúsē.

Rags, Nak-léskv.

Rail, (of fence, fort, etc.) Tohópkē.

Raiment, Vt'crken.

Rain, O'skē.

to Rain, Os'ketv.

\section{RAI}

to make Rain, v. c., Oskícetv.

Rain-bow, Os'kē-entácv.

Rain crow, 'Tvlókkē.

Rain-maker, Oskícv.

Rainy, Os'kusé.

to Raise, Kawv'petv. Mahmícetv.

to Raise, (the value) Acáyécetv. to Raise, (by culture) Lokcícetv.

to Raise up, Aossícetv.

Raised, (in a pile) Cek'hē.

Raised, (in value) Acáyéckv.

Raised-bread, Trklikè-pak'ko.

Raisins, Pvrko-cv'mpv.

Rake, Setē-cáskv. Setēkef kv.

to Rake, Cásetv. Setēcásetv.

Ramrod, Etcv-sem-vsékekv.

Rancid, Ahas'sē.

Ranges, Tvlvlv'kē.

Rank, Estánē.

to Ransom, Nes'e v.

Rapid. Mv-yakhv'mkē. Pv'fnē. to be Rapid, Mvyakhv'mketv. Rapids, Fíhnē-yek'cv.

to be Rash, Mvyák-hv'mketv.

Rasp, Essókv.

Rasp berry, Kv'co-palv'knv:

Rat, Akécē. Ces'sē-rak'ko.

to Rate, Féketv-háyetv.

Rational, Tètakúsen.

Rations, Hómpetv caúkv.

Rattle, Sv'cvcákv. Saúkv.

Rattle, (of shells) Lócv-saúkv.

to Rattle, (as dry stalks) Tvrv'rv'kketv.

to Rattle, (make a noise) Tartv'ketv.

to Rattle, Cvsvsáketv. Svmáretv. Cvsáretv.

to Rattle, v. c., Sv'marécetv.

to Rattle or crack, Kv'pvpásketv.

Rattle-snake, Cet'to-mek'ko.

Rattle-snake, (diamond) Acéntv.

Rattle-snake, (ground) Cet'tomek'kocē. 


\section{RAV}

to Rave, (as a madman) Cuknáhetv.

to Ravel, Fépètv.

Ravelings, Fep'kv.

Raven, Kak'kè.

Ravening, Nok'sē. Nok-súlkē.

Ravine, Pv'nēe. Pv'nē-súfkē.

Raw, Fv'lē. Nóreko.

Rawboned, Fúnē-tv'lkē.

Razor, Cuk-es'sē-svkáskv. Sv= káskv.

Razor-strap, Cukes'sē-skáskv-esfac'etv.

to Reach, Orícetv.

to Reach out, Awíyetv.

to Read, Oh-onáyetv. Etem'punáyetv.

Reader, Tempunáyv.

Reading-book, Nakcókv-etempunáyetv.

Ready, Etētákvtē. Tetákē.

Ready only, Eté-tihv'mkusē.

to get Ready. Etē-takuécetv.

Real, Mv-máhusat.

Really, Mehénwusē.

to Reap, Wocótetv. Vtelóyetv. Mámetv.

to Rear up, Lvpútketv. Lvpútetv.

Reasonable, Tetákusē.

to Rebuke, Vséhetv. Vsēháketv.

to Receive, Evpáyetv. Vpáyetv.

to Receive, plu. Enákuecv'ketv.

Recent, Hvtē-vwólē.

to Reckon, Momís-ómetv.

to Reckon together, Etem-fv'tcetv.

to Reckon with, Temfvt'cetv.

to Reconcile, Etén-herkēpúecetv.

Reconciliation, Eten-hessícetv. Eten-hérketv.

Red, Cátē.

Red, (very) Cántusē. Cantákusē.

\section{RED}

Red-bird, Fus-cátē.

Red-blossom, Cáte-pv'kpvkē.

Red-bud, Rvtákvpē.

Red-bug, (Cheger) Wásko.

Reddish, Okcáte. Cátusē.

to Redeem, Nes'etv.

Redeemer, Nésv.

Redemption, Póyvtē. Nes'etv.

Red-ground, Kvn-cátē.

Red-corn, Vcē-cátē.

Red-man, Estē-cátē.

to Reduce, (to powder) Lopótetv. Yukópetv.

Red-shank, Kestówv.

Red-water, Ue-cátē.

Reed, Kóha.

Reed, or sley: Kóha-hópke.

Reel, Tvkac'kucē. Es-rēcápkv.

Reformation, Hērē-háyetv.

Refuge, Vrvnáketv.

to Refuse, Eyáceko-tetáyetv.

Regal, Mek'ko-enákē.

to Regard, Moskómetv.

Regeneration, Svnv'cvmv-hec' ketv.

Region, Afópkē.

to Reign, Oh-fvn'ketv.

Reins, (of the body) Tucē.

Reins, (of bridle) Cuk-sákv-fv'kv .

to Reject, Eyáceko-tetáyetv.

to Rejoice, Afv'cketv.

Relations, Em-pvlsv'lke.

to Release, En-fvtcv'petv.

Religion, Mekusv'pkv.

Religious, Emekusápē.

Remainder, Ahóskè. Vpv'lwv.

to Remain, Ahos'ketv.

to Remain on, Oh-fekhúnnetv.

Remains, Mahos'kē.

to Remember, Eskerr'etv. Cēhósetv.

to Remember me, Svc-vkerrícetv. Remorse, Fek-nókkē-máhē. to Remove, Akuéketv. 


\section{REM}

to Remove, v. c., Akúeyícetv.

to Rend, Selahlécetv. Etē-sétketv.

Renewed, Mucv-sécetv.

Rent, Cètvk'kat.

a Rent, Sétken.

to Repay, Féketv.

to Repeat, $\mathrm{Hv}^{\prime}$ tv m-oh-máketv.

to Repent, Vkerríckv-etícetv.

Repentance, Vkerríckv-etic'etv. Etíckvn.

Report, Opunáyécan.

to Report, Opunv'kv-svwáhécetv. Oh-kerkúecetv.

Representative, Ayopóskv. Mapvkv'lkē.

to Reprove, Vséhetv. Ohkerricetv.

Reptile, Cet'to.

Republic, Tv'lemè.

to Reside, Em-vfek-hun'netv.

Residence, Líketv.

Resident, En-líketv.

Resignation, Eyaskákusē.

Resolute, Oh-fekhv'mket. Hácē. to Respect, v. c., Arakkuécetv.

Respect, Arákkuéckv.

to be Respectful, Cvpúecetv.

to Rest, Fēkhúnnetv.

to take Rest, Fēképetv. Fēkv'petv.

to Rest upon, Oh-féképetv.

Restless, Fēk-hèreko.

to Restore, Oh-fullēcícetv.

Resurrection, Akvwápketv.

to Retain, or leave a part, Ahossícetv.

to Return. Fúlketv. Oh'-fúlketv. Rvláketv.

to Return, v. c., Oh-fúlhuécetv.

to Return to, Oh-ful'ketv. Alv'ketv. Eryícetv. Res-áretv. Rv'tetv.

to Return, Rv'wetv.

\section{REV}

to Reveal, En-rámetv. Enrv'm. ketv.

Revelation, Em-eheckuécvten.

Revengeful, Em-pvlēcépetv. to Reverence, Arak'kuécetv. Reverend, Arakkúecē.

Reverent, Arak'kē.

to Revile, Opunáyécetv.

to Reward, Féketv.

Reward, Féketv.

Rheumatism, Fúnē-tihóyv.

Rib, En-tálv.

Ribbon, Tvkfúlwv.

Rib-bone, En-tálv-fúnē.

Rice, Alóso.

Rice-bird, Pucústowúcē.

Rich, Nak-ócē. Sulécē.

Rickets, Fēkēkákat ómē.

Riddle, Svláhwv.

to Ride, Córak'ko-oh-líketv.

Rider, Córak'ko-oh-líkv.

Ridge, Canvk'sat. Canvksē.

Ridicule, Vtvléckv.

to Ridicule, Vtvklécetv.

to be Ridiculed, Vtv'kletv.

Riding-whip, Rak-estep'ketv.

Riding on behind, $A^{\prime}$ vm-ohlíken.

Rifle, Et'cv-svtáhv.

Right, Fv'tcē.

to be Right. Fvtcetv.

Righteous, Fv'tcv. Fvtcē.

Righteousness, Fv'tcv. Fvt'cetv.

Right-hand, Enk-vpérv.

Right-side, Kvpérv. Akvpérv.

Rigid, Yek'cē.

Rill, Hvt'cucē.

Rind, Hvr'pē.

Ring, (of finger) Estenkēwesákvpíkv.

Ring, (round) Pvlóksē.

to Ring, (twist) Opécetv.

to Ring, (sound as a barrel) Kémkéketv.

Ringed, Cvláhē. 


\section{RIN}

Ring-worm, Hērv'pv. Elvpápv.

Riotous, Estókē-máhē.

to Rip, (ones-self) Sétketv.

to Rip, Rètvp'etv.

Ripe, (very) Lókcus-máhē.

Kipe, Lókcē. Lokcákē.

to Ripen, Lókcetv.

Ripped, Sétkē.

Ripple, Mēlórē. Melón.

to Ripple, Mēlóretv.

to Rise up, Ahúeretv. Asehoketv.

to Rise up, Alíketv. Akáketv.

to Rise up, Akvwápketv.

to Rise up, v. c., A-óssícetv.

to Rise with, As'-kvwápketv.

to Rise up against, Vnrápetv.

to Rise up, Kiyápketv.

to Rise up, (lift) Kvwápetv.

to Rise again, Ra-kvwapketv.

to Rive, Séletv. Páretv.

Riven, Sélkē.

River, Ue-rak'ko.

River-water, Uerak'ko-uéwv .

Rivulet, Hv'tcucē.

Roach, (cricket) Colótkv.

Road, Nénriē-rákko. Nénnē. spáskv.

Roan, Svpv'k-hv'tkē-ómē.

to Roar, (thunder) Tēnétketv.

to Roast, Éckópetv.

Roasting-ears, Vcē-lowvc'kē.

to Rob, Svpēnkalécetv. Horkópetv.

Robber, Horkópv. Svpēnkalécv.

Robin, Hespvk'wv.

Robust, Yékcē.

Rock, Cv'to.

to Rock, Eshánetv.

to Rock, v. c., Eshanécetv.

Rocker, Eshanēc'kv.

Rod, (a measure) Ahopákv.

Rod, (a switch) Estep'ketv. Ahos'wv.

\section{ROG}

Roguish, Hórkópvrē.

to Roll, Pulóyetv. Pvlpícetv.

Tolómetv. Pvlpáketv.

to Roll about, Apv'lpv'ketv.

Roller, Cvilá.

Roof, Cuko-ohlv'nkv. Vpettē.

Room (space) Tektv'nkē.

a Room, Nvthófv.

a Room, Nvthófucē.

to have Room, 'Tektv'nketv.

Roomy, Tvnkē.

to Root (as hogs) Wēlépetv.

Root, Tóyvlúnkv. Eto-fv'kv.

Lalun'kv. Yvlun'kv. Ces'kv.

Rope, Fvk'v. Eswvnáyetv.

Ropy, Lēpvk'fē.

Rose. Hiyópalécv.

Rose-color, Cátē-ómê.

Rosin, Culókcuwv.

Ross, (scaly bark) Ehvr'pē-ohonv'pv.

to Rot, Lek'wētv.

to Rot, v. c., Lekwécetv.

Rotten, Lek'wē.

Rotten, (as wood) Tokpáfkē.

Rotten-wood, Tukpáf'kv.

Rough, Suk'pē.

Round about coat, Kápucē. Kapv-kocóknē.

Round, Cęréhē. Kololókē. Polókē.

Round-lumps, Ceréhē.

to Row, Káfetv. Akáfetv.

in a Row, Senécē.

to stand in a Row, Senécetv.

Royal, Mekkv'lkē-nákē.

to Rub, Pvróyetv. Péyētv. Porónetv.

to Rub against, Vsóketv.

to go down and Rub, Rakpohóyetv.

Ruddy, Catē-ómē.

Ruffles, Sémvtv'tēhá.

to Ruin, Hopv'netv. 


\section{RUI}

Ruinous, Ahopánē.

Rule, Sátkv.

to Rule, (over) Oh.fvn'ketv.

to Rule. (to mark) Sat'ketv.

Ruler, (officer) Ohfvn'kv. Sēvpáyv.

Ruler, (a rule) Sosat'kv. Sénsát$\mathrm{kv}$.

Rumors, Oh-onv'kv.

Rump, E sv'kcv.

to Run, Létketv. Letkv'ketv. Tokóretv.

to Run a race with, 'Tem-áretv.

to Run after, As'sécetv.

to Run from, Pefátketv. Atókórhúecetv.

to Run this way, Alétketv. Alétécícetv.

to Run towards, Apéfátketv.

to Run towards, v. c., Aletécícetv.

to Run upon, Oh-létketv. Ohpéfátketv.

Runner, Létkv. Asécv.

Russet, Cátusē.

Rust, Yvmáhkē. Sē-áholánē.

to Rust, Sê-áholv'netv.

Ruthless, Crpv'kkē.

Rut, Elle-hv'pon.

Rye, Téleko-ahákē.

Rye-bread, Téleko-ahákē-tvklíkē.

Rye-flour, Téleko-ahákē-emfulotkv.

\section{S.}

Sabaoth, Sapéot.

Sabbath, Nettv-vcákē.

Nettv= cáko.

Sable, Lv'stē.

Sack, Súkcv.

Sacrament, Mēkusápv-emáfv'stetv.

Sacred, Vcákē.

Sacrifice, Oh-nekríckv. Sóh-nekríckv.

\section{SAD}

Sad, Eléskē. Pohyv'kē.

Saddle, Oh-pvtákv. to Saddle, Oh-pvtícetv.

Saddle-bags, Sohwēlépkv.

Saddler, Oh-pvták-háyv.

Sad-iron, Stenēpíckv.

Safe, Emvnvttépē. Ucáyēcē.

to be Safe, (escape) Emvnvt'tetv.

Safke, Hvsáfkē.

Safke-stirrer, Vtápv.

Șagacious, En-hoporénv'kē.

Sage, (wise) Hopo-rénē.

Said, Makv'kè.

to Sail, Sákvpēyetv.

Sailor, Uehv'tkv-oh-árv .

Sailors, Uehv'tkv-oh-fullv'lkē.

Saint, Mekusápv-hērat.

Sake, Vrah'kv.

Salad, Nak-lánucē.

Salamander, Hv'cē-tékv.

Saleable, Wiyv'kē-táyē.

Saleratus, Trklikē-espakkuéckv.

Sallow, Lánē.

Salt, Okcvn'wv.

to Salt, Okcv'nwēcetv. Okcvnvpáyetv.

Salt-cellar, Okcvn'wv-vteh'kv.

Saltish, Ok'cvn-cvm'pē.

Salt-mine, Ok'cvn-enkor'kv.

Saltpetre, Ok'cvn-rak'ko.

Salts. Hēles-okcvn'wv. Okcv'nhēléswv.

Salt-water, Ue-okcv'n-cv'mpv .

Okcv'n uéwv.

Salutation, Vsékē.

to Salute, Vséketv.

Salvation, Hēsáhuéckv.

Salve, Lek'wē-essíkv .

Same, Etáwvn. Táwv. Mátvwvn.

Same, Mvtán. Isē.

Sanctification, Naor'ketv-enhvsvtécetv.

to Sanctify, Hvsvtécetv 。 


\section{SAN}

Sand, Oktáhv.

Sand, (quick) Oktáhv-ak'súmóhē.

Sand-bar, Okta-hv'tkē.

Sand-hill crane, Watúlv.

Sand-stone, Cvto-sok'pv.

Sandy, Oktáhē.

Sap, Em-okórv. Eto-mopúswv.

Okórv.

Saque, (of laddy) Kápucē.

Sarsaparilla, Lvlúnk-lánē.

Sash, Sóhwvnákv. Sakfúlwv.

Sassafras, Wéso.

Satan, Estē-nekrícv. Sétvnē. to be Satisfied, Vhlvpátetv. $\mathrm{Cv}$ por'retv.

to Satisfy, Cv porrícetv.

to Satisfy, Máhlvpv'tetv.

Saturday, Sátvtēe. Nettv-cákocúsē.

Sauce, Sēwápho. Hokētésv.

Saucer, Sesketúcē-empvtákv.

Saucy, Holwayēcē.

Sausage, Fékcē-semvtéhkē.

Savage, Holwayēcv'kē.

to Save, Vcáyécetv. Hēsáyetv.

Hēsáhuécetv.

Saving, Vcáyecvket.

Savior, Hēsáyécv. Hesahúecv.

Savour, Vlóstetv.

Saw, Esfókv. Es'kétkv.

Saw, (cross cut) Esfokv-rákko.

Saw. (whip) Esfókv espor'kv.

to Saw, Fóyetv. Eskétketv.

Sawyer, Eto-fóyv.

Sawyer, (a worm) Ewvkátv.

to Say, Máketv. Kícetv. O'ketv.

Saying, Okē. Makē.

Sayings, Punv'kv.

Scaffold, Oh-tíhē. Tikucē.

to Scald, Ak-rófetv. Rófetv.

Scald, Ak-róf kv.

Scales, (films) Nakcélkv.

Scales, Svtárkúeckv-rákko. Svtárkuéckv.

\section{SCA}

Scalp, Estekv-hv'rpē.

a Scalp on a tree, $V_{c v}$ skelv.

Scanty, Kosv'p'ke.

Scar, Tr'ckvtē.

Scarce, Nvcómes. Estómosen.

Scarcity, Kusápkē.

to Scare, Penkvlécetv.

to be Scared, Penkv'letv.

Scarey, Penkálē.

Scarlet, Okcátē.

to Scatter, v. c., Vnahēcetv.

to be Scattered, Vwáhetv.

Scattering, Rémhē.

Scattered, Cesv'pkè.

to Scent, Wēnáyetv.

to make Schism, Tékvpáyetv.

Schallot, Tafr'mpè-oínē.

Scholar, Nakcókv-en-hécv.

School, Nakcókv-mvhákv.

School-master, Nakcókv -mvháyv.

School-fellow, Nákcókv hécv-em$\mathrm{pv}^{\prime} \mathrm{ls} \overline{\mathrm{e}}$.

School-house, Mvhákv-cúko.

Scissors, Eskótkv.

Scissor-tail, (a bird) Hv'cē-teyákpo.

to Scold, Ehánetv. Ehanhúecetv.

to Scorch, Etópketv.

to Scorn, Ewéyetv. Ew'etv.

Scornful, Ewéyè-ómē.

Scorpion, Vcóklepá. Hv'cē-estē-

ráhv.

to Scourge, Tep'ketv.

Scourge, Es-tep'ketv.

to Scramble, (as with sticks) Vsóyetv.

to Scrape, Vkásetv. Kásetv. Róf ketv.

to Scrape inside a vessel, Kátetv. Scraped, Róf kē.

to Scratch, Hos'ketv. Wósetv.

to Scratch with needle, Sápetv.

a. Scratch, Sápkv.

to Scream, Hueh'ketv. Sēlakséketv. 


\section{SCR}

Screw, Svfíyety. Fēyeyékē. Screw-plate, Svfíyetv-esháyetv. Screw-driver, Svfíyetv. to Scribble, Kvsáyetv. Scribe, Hotcícv. Scribes, Nakcókv-hayv'lle $\overrightarrow{\text {. }}$ Scrip, Ehv'lewv.

Scriptures, Nakcókv-rákko.

Scrofula, Nok-lékwe.

Scrubby, Lopútskv'lkē. Kentv' " kè.

Scythe, $\mathrm{Pv}^{\prime}$ hè-es-táckv。

Sea, Ue-hv'tkv.

to Seal, Soh-lókpícetv.

Sealing-wax, Setē-lokpic'kv.

Seam, Mvhor'kv. Etēhorkv.

Seamstress, Mvhor' $\forall$.

to Search, Hopóyetv.

Season, O'ketv.

Seat, Ohliketv. Oh-vpóketv.

to Seat, Lícetv. Hayícetv. Apoyícetv.

Sea-water, Uehv'tkv-uéwv.

Second, Svhókkólv.

Second, (of time) Etekvpv'kē.

Secondly, Svhokkóle.

Secret, Eh'kē. Eh'kusē.

Secretary, Hotcícv.

Secure, Vcayécē.

Sedate, Márvps'tkē.

to See, Hécetv.

to See, v. c., Hecícetv.

to See-saw, Cvken-cícetv.

Seed, Ner'kv. Púrwv.

Seed, (for planting) Vhocvránv.

Pórnv.

to Seek, Hopóyetv. Espóyetv.

Seeker, Hopóyv.

to Seem, Mómē-ónt.

Seldom. Omáhv̀. Omáhusē.

Select, En-hopokē.

to Select, En-wíketv-háyetv. Enhopóketv.

Self-denial, Nakē-enkvpv'kē.

\section{SEL}

Self-examination, E-yv'ketéckv。 E-vketécetv.

Selfish, E-kvsv'mē.

Self-knowledge, E-áhoporēnv'。 $\mathrm{kv}$ 。

to Sell, Wíyetv. Er-wíyetv.

seller, Wíyv.

Seminole, Seminolē.

Senator, Vhákv-háyv.

to Send away, Ayēcícetv. Atótetv.

to Send forth, or off, Atótetv.

to Send to or on, Oh-tótetv.

Senseless, Hoporéneko.

Sensible, Hoporénè.

Sensitive plant, Kvcas'setv.

to be Separate, V'lketv.

to Separate, (divide) Etekvpícetv.

Sētenkvpv'kety.

Sepulchre, Estē-hoper'kv. Cvtokóf kè.

September, Oto-wóskucē.

Serene, Coyiyákē.

Serious, Marvpv'tkusē.

Sermon, Erkēenv'ketv.

Serpent, Cétto.

Servant, Svlv'fkē. Vtótkv.

to Serve, Vtótketv.

to Set, (place) Lícetv. Kayícetv.

to Set aside, Vpóyetv.

to Set fire to, Svhëtécetv. Hopotécetv.

to Set out, (as trees) Rvfécetv.

Seven, Kulvpáken.

Seventeen, Palen-kulvpohkáken.

Seven-sıars, Cuk-lof'kv.

Seventh, Es'kulvpákē.

Ševenty, Pálē-kulvpáken.

Severe, Nokkēmáhē. Akvsvme. cícusē.

to Sew, Vhorhúecetv. Ahor'ety. Vhueretv.

Sewed, Vhórkē.

Sewer, Vhórv. 


\section{SEX}

Sexton, Mekusv'pkv-cúko-vhecícv.

Shade, Vpéttē.

Shady, Vpéttē.

to Shake, Nêkéyetv.

to Shake, v. c., Trméyícetv. Yekēsícetv.

to Shake another with, Es-fvmóyetv.

to Shake as a brush, Fvmóyetv.

to Shake hands, Vséketv. Fēnóyetv.

to Shake hands with, Es-fēnóketv.

to Shake the head, Norátetv. Nvráyetv.

to Shake the head, v. c., Noraticetv.

to Shake off, Afekéyetv.

to Shake one's self, Es-fvmóketv.

to Shake the tail, Fv náyetv.

Shaking, Fenokē. Nēkéyē.

Shaking water, O'kē-fenókē.

Shall be, Tárēs.

Shallow, Cah'kē. Cah'kusē.

Shameless, Vl'seko.

Shame, Vlésketv.

Shank, Hvc'kēwv.

Sharp, Fvs'kē. Trpestv'kē.

to Sharpen, Fv sécetv.

Shattered, Cesvp'kē.

to Shave, Vkásetv.

to Shave or dress, (with knife) Kvly'fety.

Shaved, Akáskē.

Shaving-brush, Svpakpvkuécky.

Shavings, Trkhv'f-vpē.

Shawl, Noc'kv-rak'ko.

to Shear, Tónetv,

Shears, Sentónkv. Sēnkótkv.

Shears, Eskótkv-rak'ko.

a Shed, Soh-vpéttv.

to Shed itself, Etónetv. Letéfketv.

Sheep, Yvpefíkv:

\section{SHE}

Sheet, Topv-oh-rvn'kv.

Shelf, Nak-sóh-apóyv. Oh-vpó$\mathrm{kv}$.

Shell, E-hvr'pē.

to Shell, Kelásetv.

to Shelve, Soh-vpóyetv.

Shelves, Oh-vpókv.

Shepherd, Ahēcícv.

Sheriff, Este-wvnáyv.

Shield, Semv-natépkv. Es-vpácetv. Sevrrnv'kv.

to Shield, Vpácetv.

Shin, Hvc'kewv.

Shin-bone. Hvc'kewv-fúnē.

to Shine, (glisten) Holv'cetv.

to Shine, (as the sun) Hvsótetv.

to Shine, Hiyayícetv. Hiyayáketv.

to Shine, Ye-hiyayv'ketv.

to Shine in, s. Ahíyayícetv.

to Shine in, d. Ahiyáyvhóketv.

to Shine in, p. Ahiyayv'ketv.

to Shine upon, Oh-hiyáyícetv.

Shingle, To-sélkv.

Shiny, Hólocē.

Ship, Pérro-cúko.

Shirt, Yokof'ketv. Ayokkófkv. Shirt, (hunting) Kápv.

Shirt, (ruffled) Yokófketv-semvtv'lehv.

Shirt-bosom, Yokóf ketv-hókpē.

Shoat, Súkhvcē.

Shoe, Estellepíkv-wvn'hē.

Shoe-brush, Estellēpíkv-spáskv .

Shoe-hammer, Estellepíkv-sv tó-

kucē.

Shoe-maker, Estellepíkv-háyv.

Shoe-string, Estellepíkv-fv'kv .

Shooter, Ráhv.

to Shoot, Rah'etv. Et'cetv.

to go and Shoot, Rétcetv.

to Shoot with, Sétchetv.

Shore, Afop'kē. Asénkv. Uevfópkē. 


\section{$\mathrm{SHO}$}

Shorn, (as hair) Ton'ke.

Shortalegged, Vcv'kusē.

Short, Kocuk'nē. Kocuncóke.

to Shorten, Kocun'cóketv.

Shot, Rè-lopúts'kē.

Shot-pouch, Suk'cv-tvpek'sē.

Shoulder, E-ful'owv.

to Shoulder, Waron'etv.

Shoulder-blade, Fulop'-tvpéksē.

Shoulder-joint, Fulop'tohtek'ekv.

Should have, Tetáyuset-ómes.

to Shout, Yv'hketv. Hayv'hketv.

to Shove, Aheprk'etv.

Shovel, Stak kefkv. Estak-kéf$\mathrm{kv}$.

to Shovel, Kéfetv.

to Show forth, En kerkúecetv.

to Show, Hecícetv.

to Show another, Er-hēcícetv.

Shower, O'skē.

Showery, Os'kucē.

Shrill, (noise) Sewv'ktē-óket.

to Shrink, Etē-kéletv.

to Shuffle, Súlusúecetv.

Shrub, Vhóswv. Eto-póhkē.

to Shut, Akhóttetv. Akhótketv.

to go and Shut, Rak-hóttetv.

Shut, Akhótkē.

to Shut the eyes, Mosúletv.

to Shut to, E-oh-ákhóttetv.

to Shut up, Oh-ákhóttetv.

Shuttle, (weaver's) Tv'retv-esropóttv.

Sick, Enókkē.

to be Sick, Enóketv. Nóketv. Pulsetv.

Sickle, Es-wvcótetv. Es-tvcetv.

Sickly, Púlsē.

Sickness, Ennok'ketvn.

Sideling, Svtv'knē.

Side, Env'cē. Nv'cē.

Side, (above the hip) Essik'sv.

Side, (below armpit) Envc'è-tvkhókē.

\section{SID}

Sidewise, Svtv'knē. Crvnv'ksē.

Sieve, Esyókv. Svláhwv.

to Sift, Esyoyetv.

Sifter, Esyókv.

to Sigh, Hihketv.

Sign, Svhopákv. Nakē-eskerretvn. Eskérkv.

to Sign, (as your name) Alumhícetv.

Signal, Svhopákv.

Silence, Ciyayáketvn.

to Silence, Ciyayícetv.

Silent, Ciyáyvkē.

to be Silent, Ciyayetv.

to Silk, (as corn) Vtoklópety.

Silk, Afus-hēra.

Silk-grass, Suwénv.

Silk-weed, Nócē.

Silk-worm, Afús-hēren-háyv.

Sill, or sleeper, Cuk-éllē-rákko.

Silly, Hoporé-nēko.

Silver, Cvtokunv'p-hvt'kè.

Silver-mine, Cvtokuriv phv'tkē-en. kor'kv .

Similar, Ahákē.

Simile, Es-vhopákv.

Sin, Holwayéckv. Naor'ketvn.

to Sin, Holwayécetv. Naor'ketv. Mv'ttetv.

Since, Vtē. Mómvte-vtékat.

Sincerely, Mēhenwícusē. O'rusē. Sinew, Acv-fv'kv.

Sinful, Holwayécē. Naórkē.

to Sing, Yvhíketv.

to Slng to, Ayvhiketv.

to Singe, Trk-fap'etv. Fápetv.

Singer, Yvhíkv.

Single-tree, Yopúmv-tvkhákv.

Singular, Ahákeko.

Sinister, Holwayécē.

Sink-hole, Ak-léfē.

to Sink, Ak-súmketv.

Sinner, Holwayécv. Naórkv.

Sister, (elder of a man) Crwv'nwy 


\section{SIS}

Sister, (younger of a man) Cvchústē.

Sister, (elder of a woman) Cvráhv.

Sister, (younger of a woman) Crcúsē.

to Sit, Líketv. Káketv. Vpóketv.

to Sit by a person or thing, Aliketv.

to Sit Low down, Tvkliketv.

to Sit up, Aliketv.

Six, Epáken.

Sixth, Esēpákē.

Sixty, Palè ēpáken.

to Skate, Esoh-solv'tketv.

Skein, Es-wvnákucē-hv'mken. Vfúswvnv'ke.

Skiff, Perrocē. Pérrolv'ncv.

Skillet, Svk-moreckv.

Skillful, Mvnv'ckē.

to Skim, Mvk-caúetv.

Skimmer, Sem-akcaúkv.

Skin, Hvr'pē.

to Skin, Torófetv.

to Skip, Tas'ketv.

Skirt, En-hun'nv.

Skittish, Pen'kálē. Fekcákhē.

Skull, Est-ékv-fúnē.

Skunk, Kúnu.

Sky, Sútv.

Sky-blue, Ahólncē-okholátē.

Slack, Yulóhē.

Slack-water, Ue-yulóhē.

Sla e, or Sley, (weavers' reed) Es-tar'kv.

to Slander. Opunv'kv-en-háyetv.

Slander, Opunv'k-ehákv.

Slanderer, Opunv'kv-en-háyv.

Slanderous, Opunv'kv-enháyē.

to Slap, Cefokkícetv.

Trate, Cvto-tvlópsē. Cvto-lv'stē. late-quarry, Cvto-tvlópsē-en$\mathrm{k} \circ \mathrm{r}^{\prime} \mathrm{kV}$.

ve, SvIv'fkè.
SLE

Sled, Eto-es-sofotec'kv.

Sledge-hammer, Svtókv-rak'ko.

Sleek, Tenépē.

Sleep Nuc'kv.

to S'leep, s. Núcetv. Nucépetv.

Nucicécetv.

to Sleep, p. Nucicē-cv'ketv .

Sleepy, Nuc'kēlē. Nuckv-ēle. óme.

Sleet. Oskē-eshētútē. Hētútēner'kv.

to Sleet, Estenēpícetv.

Sleeve, En'kē-sumfulot'kv.

Sleigh, Hetútē-es-oh-hvlátetv.

Slender, Ros'wē. Rafok'sē.

Sley, or slaie, (weaver's) Es-tar' -

kv. Kóha-hópkē.

to Slice, Séletv.

to Slide, Es-alvt'ketv.

Slim, Rafok'sē. Ros'wē.

Slime, Lepv'kfē.

Slime-pit, Oklvwáhē.

Slimy, Lepv'kfē.

to Slip, Solótetv.

to Slip, Rēpássetv. Tēnáspetv.

Enrēpas'setv.

to Slip out, Rēcóketv.

Slippery, Tēnáspē. Rēpas'sē.

Slippery-elm, Lupákv.

to Slit, Sēlv'ketv.

to Siobber, Tukríhnetv.

to Slobber on, Vtoklomáketv.

Slothful, Enhorē. Horkē.

to be Slothful, Hóretv.

Slovenly, Lēkv'cwē.

Slow, Yulóhusē. Pvlvlv'kē. Yóp$\mathrm{k} \overline{\mathrm{e}}$.

Slow, (to Speak) Hvlatot'kusē.

Sly, Em-vkérē.

to make Small, Lopótecícetv.

Small, C-út'kē. Lopútkē. Hvkpvtē.

Smaller, Cútkusē. Hv'kpvtè.

Smallest, Cútkvs-màhē. 


\section{SMA}

Small-pox, Lécēkákv.

Smart, Crfek'nē. Herómē.

to Smash, Wokócetv.

to Smell, En-séf'ketv. Vwvnáyetv. Húnwetv.

to Smile, Mosul'letv. Vpelúsetv.

a Smile, Vpelúsv.

to Smite, Nvf'ketv. 'Tekáyetv.

Smoke, Ek'kucē. Ékkócē.

to Smoke, Ekkúcetv.

to Smoke, Smók-kícetv.

Smoking, Ekkócat.

Smoking, (a person) Es-mok'kicet.

Smoky, Ekkúcē-v'lkē.

Smooth, Mut'kē. Ténepē.

to Smooth, Tenēpícetv.

Snack, Hómpetv-estómusen.

Snail, Sestē-súmkv. V'tv. Lv'pv.

Snake, Cétto.

Snake bite, Cétto-estv'kkē.

Snake, (black) Cètto-lvstē.

Snake, (chicken) Apv-yákv.

Snake-dance, Cétto-háyv.

Snake, (garter) Cétto-lánē.

Snake, (ground rattle) Céttomékkocē.

Snake, (joint) Cétto-kv'cekv.

Snake, (rattle) Cétto-mékko.

Snake-root, Culéssē-fv'mpē.

Snare, Senkv'nhetv.

to Snatch from another, Tèhvnáhetv. Kvlatúecetv.

Snath. Prhē-estáckv-emv'pē. Pvhe-swárkv-mv'pe.

to Sneak along with, Es-yopécetv.

to Sneeze, Hvktes'ketv.

to Sniffle, Sē-vres'ketv.

Snipe, Ak-caúhko.

to Snore, Rvtak'ketv.

to Snort, Saúbketv. Tulósketv.

Snout, Yúpo.

Snow, Hetútē-rak'ko.

to Snow, Hetútetv.

\section{SNO}

Snow-bird, Cuko-lóswucē.

to Snuff, Es-hvktésketv.

Snuffers, Kulkē-sen-tac'kv.

So-so, Yómē.

So, Vtē. Tis. Hv'munt. Matv-

pómen. Hiyómen.

So much, or great, Mómvtékat.

Soap, Svkos'kv.

Soap, (bar) Svkos'kv-lánē.

Soap, (dish) Svkos'kv-vteh'kv.

Soap, (shaving) Svkos'kv-cukes'sē-essvkáskv.

Soap-stone, Tvlópē.

Sober, Máhlvpv'tkē.

Sobriety, Hácekó.

Sock, Stelle--svoh-cac'kv.

Socket. (of eye) Tur-hv'po.

Sod, Pēhecékcē.

to be Sof, Okómetv.

Soft, Lowvc'kē.

Soft, (very) Lowv'ckusē.

to Soften, Lowvcécetv.

Soft-shelled turtle, Holákwv.

to Sojourn, s. Tv'llepóretv.

Soil, Ekv'nv. Fákkē.

Soldier, Súletáwv.

Soldiers, Suletawv'lkē.

Sole, (of the foot) Elle-ófv.

Sole, (alone) En-hvm'kusē.

Solitary, Enhv'mkusē.

Solemn, Hoporénusē,

Some, Vpvl'wv. Sásē.

Sometimes, Estófvtis. Estófis.

Somewhat, Estómusen.

Somewhere. Estómvtis.

Son, (of a man) Eppúcē.

Son, or daughter, (of woman)

Echus'wv.

Son of Man, Eppúcē.

Song, Yvhíketv.

Song-book, Nakcokv-esyvkíket

Son-in-law, Hvtēsē.

Sons, (of a man) Eppucetáke.

Sons, (of a woman) Custakè. 


\section{$\mathrm{SON}$}

Son's son, Eppúcē. Eppúcētákē. Soon, Lvpkusē. Enlvpkē.

Sorcerer, Pórv. Etem-pórv.

Sore-eyes, Tur-nok'kē.

Sore mouth, Ecúk-lek'wē.

Sore throat, Nok-feh'pv. Enno'k'ke

Sores, Lekhówē.

Sorrel, (color) Cátusē.

Sorrow, Efékē-nok'ketv.

Sorrowful, Efékē-nok'kē.

Sorry, Efékē-nok'kē.

Soul, Puyvfek'cv. Yvfékcv.

Sought after, Aráhkvtē.

Sound, (whole) Lékwekó.

Sound, (noise) Hakē. Enhákē.

to Sound, Kemkécetv.

to Sound on, Oh-fohíketv. Ohfoh'ketv.

Sounding water, Uetrmtómkv. Uetv'mkv.

Soup, Opus'wv.

Sour, Tok'sē. Kvmóksē.

South, Wahv'llv.

to Sow, Fokáyetv. Fēkáyetv.

Sow, Sukhv-hóktē.

Sower, (of seed) Fēkáyv. Fokáyv.

Space, Tektv'nkē. Tr'nkv.

Spacious, Tektvn'kē. Tv'nkēmáhē.

Spade, Es-kor'kv.

Spaniard, Espánē.

Spanish-fly. Cánv-lánē.

Spanish-oak, Tókv-máhv.

to Spare, Acayécetv.

Spark, Wēcárv. Wēcvcárē.

to Sparkle, Es-wēcáletv.

to make Sparks, Wēcarécetv.

Sparrow-cock, Cutkucv'lkē-hu$n v n^{\prime} w v$.

Sparrows, Cutkucv'lkē. Cēlékkv. Speaker, Em-punáyv.

to Speak, Onáyetv. . Opunáyetv. $\mathrm{O}^{\prime} \mathrm{ketv}$.

\section{SPE}

to Speak, v. c., Opunáyécetv. ta Speak to, Kícetv. Kicv'ketv. to Speak, (different languages) Cēlókketv.

Special, Aherícet.

Specially, Máhvkáu.

Speckled, Lvkáhē. Tvkóhē. Tesáhē. Fesáhle.

Species, Tēcak-áyē.

Spectacles, Tur'wv-svkkákv.

Spectator, Oh-hécv.

Speed, Alécē.

Speedy, Ahēcícē.

to Spend, Wíyetv. Yvmáhkuécetv.

Spice, Kvprpas'kv.

Spicewood, Kvpvpáskv.

Spider, Acukrvn'wv. Hacukrv'nwV.

Spider, (long-legged) Tvpóhsv'lv. Spider-web, Acúkrvnhóyv.

a Spike, Vcopv-rákko.

to Spill, Pvlátetv.

to Spin, Fvllécetv.

Spindle, Es-fvllécetv.

Spinner, Fvllécv.

Spinning-wheel, Es-fvllec'kv.

to Spire, (to shoot up) Fvlécetv.

Spirit, Puyvfékcv. Yvfékcv.

Spirits of camphor, Kvnok'ke-hēléswv.

Spirits of turpentine, Colókcowv. Spiritual, Puyvfek'cv-vpv'kē.

Spirit-world, Puyvfek'cv-tvlófv.

to Spit, Tof'ketv. Poc'ketv.

to Spit blood, Catē-tóf ketv.

to Spit on, Ohtótketv. Vtóf ketv. Spitting-blood, Cátē-tof'ket.

Spittle, Toklos'wv.

to Splash, Téfes'ketv.

Spleen, Lúpē-cápko.

Spleen-enlarged, Lúpē-cápkoawvn'hē.

to Splice, Atvlíyetv. 


\section{SPL}

to Splinter, Sauwóretv.

Splinter, Nahv'pē.

to be Splintered, Nahv'petv.

to Split, Fulv'petv. Trkócetv.

to. Split off, Lusvf'etv. Lusv'kkē

to Split, or crack, Par'etv. Tvkócetv.

Split, or cracked, Par'kē. Sélkē.

Split open, Fulvp'kè. Fulv'pē.

Split into many parts, Fulv'klē.

Fuláhlē.

to cause to Split, Fúlvlécetv.

Spoiled, Vhopvn'ke.

to Spoil, Vhopv'netv. Hopv'nketv. Hopánetv.

Spoils, Vhopv'nē.

Sponge, Uepv'tv.

Spool, Afus'wv-apvllákv.

Spoon, Hákkucē. Hákkv.

to Sport, Oh-kopvn'etv.

Sport, Oh-kopvn'kv.

Sput, Alíkosē.

Spotted, Lvvkáhē. Tvkóhē. Fe-

sáhē.

Sprained, Cvrotkē.

to Spread, Pvtaketv.

to Spread abroad, Mvmécetv.

to Spread, v. c., Pvtapícetv.

to Spread on, Oh-hócetv.

to Spread out, (the legs) Svyókletv.

to be Spread out, Atvléksetv.

a Spring of water, Uekíwv.

Spring-frog, Aktuláswv.

to Spring forward, Hofóletv.

Spring, (hot) Uekíwv-híyē.

Spring, (medicinal) Uekíwv-hēleswv.

Spring, (oil) Uekíwv-néha.

Spring, (season) Tasáhcē.

Spring, (sulphur) Ueki-tohottvplánē.

to Spring up, Afih'netv.

to Spring up, (as grain) Hóntety.

\section{SPR}

to Sprinkle, Fésketv. Fesalécetv. to Sprinkle upon, $O h^{\prime}$-fes'ketv.

to Sprout, Húntetz.

Sprouting, Húnte.

Sprout, Vhóswv. Thúntusa.

to Sprout, Vhúntetv.

Sprouts, (hickory) Pénúsv.

Spruce, (wood) Cúle-ómē.

Spun-yarn, Fvlléckv.

Spunk, Tokpáfkv. Páto.

Spur, Es-cef'ketv. Céf kv. Spur-strap, Escef'ketv-fv'kv. to Spur, Cef'ketv.

Spur of chicken, En-cvháh'tv. Spy, Vketécr.

to be Square, Svtáhetv.

Square, Svtáhē.

to Square, Svtahécetv. Svtahuécr'ketv.

Square-house, Cúko-rak'ko.

a Square, (tool) Vhopákv.

Squash, Trhóyv.

to Squat-down, Tekvk'setv.

to Squall, S`lak'ketv.

to Squeeze, Wēten'etv.

to Squeeze on, Soh-wēténetv.

to Squeeze with, Svwèténetv.

Squirrel, Eró.

Squirrel, (black) Erć-'v'ste.

Squirrel, (flying) Wíyo.

Squirrel, (fox) tror'le-láne.

Squirrel, (red) Eró-cáte.

Squirrel, (ground) E'sko.

to Squirt, Poc'ketv.

to Stab, Sēkéyetv. Pokv'fetv.

Stable, Corak'ko-húte.

Stack, Es-cv'hè.

Staff, Sētékkekv.

Stag-beetle, Soksóh.

Stag, (deer) E'co-hunvn'wv.

Stairs, Acémketv. Soh'-cem'ketv, Ohtíhē.

Stakes, (in ball play) Yvkyápv. Stale, Vcúle. 


\section{STA}

Stalk, V'pē.

Stamp, Oh-refk'etv.

a Stand, Oh-hómpetúcē.

Stand-back, Ecv'kēlv'kes.

to Stand, Húeretv. Sehóketv. Svpv'kletv.

to Stand, Huyíretv.

to Stand by, Ahúeretv. Asehóketv.

to Stand, (down in) Akhúeretv. Aksahóketv.

to Stand, (for) Ayósket-húeretv.

to Stand, (on all fours) Toh. éksetv.

to Stand on, Oh-húeretv.

to Stand tiptoe, Tekénketv.

to Stand up, Ahúeretv, Asvpv'kletv.

Standard, Tvle-lennv.

Standing afar off, Svláhwē.

Standing, Huerē. Sehóyē.

Star, Kococum'pv. Vkolas'wv.

Starch, Estv'k-vcwéckv.

to Startle, Yēkes'sícetv.

to Starve, (or fast) Eláwetv.

to Starve, v. c., Elawécetv.

State, En-huéretv.

Staves, Eto-war'ke.

to Stay (abide) Liketv.

to Stay, (loiter) Mvcéwetv.

to go and Stay with, Rvpv'ketv.

Steady, Yek'cē.

to Steal food, Nóksetv.

to Steal, Horkópetv.

Steam, Hēf kē.

Steam-boat, Pérro-híyv.

Steel, Cv'to-tot'kv.

Steel-yards, Svtarkúeckv. Svtár-

kv. Cvto-keretv.

Steel-trap, Svkkepúeckv.

Steep-place, Aknv'ttē. Akēleftē.

Steep, Ak-alv'lvkē. Aknv'thē.
STE

Steeple, Onv'pv.

Steer, Wakv-tého.

Stem, Em-v'pē.

to Step, Ellē-vwíketv.

Step-father, Erkúcē.

Step-mother, Etskúcē.

Steps, Soh-cémketv.

Steward, Nak-vfástv.

to Stick, Sēkéyetv.

to make Stick in, Acv'khécetv.

to make Stick in, Acv'khécepúecetv.

to Stick down, Aksēkéyetv.

to Stick down, v. c., Akcv'kcvhé. cetv.

to Stick fast, Alóf ketv.

to Stick in, Acv'kcvhécetv.

to Stick into, Alókpetv.

to Stick to, v. c., Alokpícetv.

to Stick to, v. c., Aloklopícetv.

to Stick up, Cv'kcvhécetv.

Sticking fast, Alófkē. Alíkē. Vlókpē.

Sticking to, Alúmhē.

Sticks, (for games) Kenehókē.

Sticky, Trlv'swè.

Stiff, Tvkácwē. Cuéhē. Tv-

láphē.

to be Stiff, Cúēhetv.

Stiffened, Tvlv'phē.

Still, Lekúthe. Mécē-múnks.

to be Still, Fēkhun'netv.

Still-better, Res-en-hēret.

Sting, (of insects) Enrē, Fo-tv'kletv.

to Sting, Ráhetv.

Stingy, En-cákē.

Stingy, (towards each other)

Etem-en-cakē.

Stink, Fv'mpē.

to Stink, Fv'mpetv.

to Stir, Téyámetv.

to Stir with, Sēteyámetv.

Stirrup, Oh-huéretv. 


\section{STI}

Stirrup-leather, O'hhuéretv-fv'kv. to Stitch, Vhuéretv.

to Stitch, Pv'kvhórctv.

a Stuck, Vpē.

Stock, Apuékv.

Stockings, Est-el'lē-svhocác'kv. Svhocáckv.

Stomach, Nvr'kē.

Stone, $\mathrm{Cv}^{\prime}$ tocē, $\mathrm{Cr}_{\mathrm{v}}^{\prime}$ to.

Stone-bruise, El'lē-enhat'kv.

Stone-quarry, Cv'to-eskor'kv.

Stony, Cvto-vlkē.

Stool, Ok-líketv.

to go to Stool, Vkéfetv.

to Stoop, Cunéketv.

to Stoop while running, Cunēnétketv.

Stooped, Cunékē.

Stooped down, Pvtakvtes.

to Stop, Fekhúnnetv.

to Stop running, Vtv'cketv.

to Stop the running, Vtv'cetv.

Store-house, Néskv-cúko.

Store-keeper, Es-nésv.

Storm, Hótvlē-rak'ko.

Stormy, Os'kē èhotvlē. Hótvlēmáhē.

Stout, Yek'cē.

Stove, Cv'to-tót'ki-hútē,

Stove-pipe. Akkócē-hútē.

Straight, Lvput'kē, Fv'tcvn.

Straight with, Svfv'tcv.

to Straighten, Lvpotécetv.

Straightway, Vpáken. Lv'pkusē.

to Strain, Aktáyetv, Cēyv'lletv.

to Strain at, (to milk) En-cullícetv.

Strait, Cútkē. Cútkusē.

Strange, Ker'reko. Vráhkē.

Stranger, Estē-kēr'rekót. Tvrēporv.

to Strangle, Nokcáketv, Es-nokcáketv.

Strap, Es-wvnákv.
STR

Straw, Pv'h

straw-bed, Pıh-ohpvtákv

Strawberry, Kēpálv.

to Stray, Ehósetv.

Stream, Fih'nē. Hékē.

Stream, (up) Vr'epv.

Street, Tehoyv'nkv.

Strength, Yekcē. Yékcvkē.

to Strengthen, Yekcícetv. Yek cvkúecetv.

to Stretch, Rotosécetv. Enhófketv. Senepécetv.

to Stretch the arms, Tv'kopvtáyetv.

to Stretch the legs, Hoféyetv.

to Stretch one's self, Eténetv. Sēnépketv.

to Stretch out, Ehvlv'tetv.

Stretched, Rotóskē.

Strife, Eten-rv'pkv.

to Strike, Nv'fketv. Nvfkv'ketv.

to Strike against, A-nv'f ketv.

to Strike fire, Kvsatúecetv.

to Strike in water, Ak-nv'f ketv.

to Strike with fist, Pv'fketv.

String, (rope, cord, etc.) Wvnákv. Fv'kv.

to Strip, Tórketv. En-tvlécetv.

to Strip off as bark, Tvlécetv. Efésetv.

to Strip off blades of corn, etc. Cus'ketv.

Stripe, Sapsv'wv.

Striped, Sápsvwē.

Striped-snake, Cet'to-sapsv'wē.

to Strive, Vcēyvl'letv.

to be Strong, Yékcetv.

Strong, Yek'cē.

Stronger, Svn-yékcēs.

to Strut, Ekvsv'mē. Yvkv'petv.

Student, Nakcókv-en-héckv.

Studious, Fēk-hun'nehécē.

to Study, Vkerrícetv. 


\section{STU}

to Stuff in, Vténketv.

to Stumble, El'len-tap'petv.

to Stumble, Sentáppetv.

Stump Tokēcéskv.

Stupid, Nuc'kv-ēlē-ómē.

Sturgeon, Nókcvpē háukē.

to Subdue, Muntv'letv.

Submission, Emē-wíketv.

to Submit, Emē-wíketv.

Substance, Nakē-ocákē.

to Substitute, Ayopósketv.

Subtly, (cunningly) Aker'rē.

Subtracted, Vkássē.

to Subtract, Vkássécetv.

Such, Yv-ómē.

to Suck, Cok'etv. Oksópketv.

to Suck, (with the tongue) $\mathrm{Yol}^{\prime}$. ketv.

Sucker, (a fish) Cuk-puéhē.

Sucker, (of corn) En-suk'kv.

Sucker, Crkfvcè.

to Suckle, Coyícetv.

Sucklings, Cokákusat.

Sudden, Ayvkhv'mkē.

Suddenly, Ayvkhv'mkusē.

to Suffer, Esstemer'retv.

to Suffer, (permit) Etektvnécetv.

to Suffer with, Sestemer'retv.

Sufficient, Tetás. Tetáyē.

Sufficiently, Ore-hēren. Tetáyusen.

Sugar, Vsókulv.

Sugar-bowl, Vsokulv-vteh'kv.

Suicide, E-èlécetv.

Sullen, Cvpv'kē-ómē.

Sulphur, 'Tohot'tvp-lánē.

Sultry, Lekónt-hósē.

the Sum, Vhónkv'tkv.

Suinach, Tv'wv. Cúwv.

Summer, Mes'kē. Hiyo.

to Summon, En-hueh'ketv.

Sun, Hvs'è.

Słun-burnt, Hv'sē-nekrícē.

Sunday, Net'tv-cáko.

\section{SUN}

Sun-down, Hvs'è-aklat'kv.

Sun-ēclipsed, Hv'sē-teyv pos'kē.

Sun-fish, Ak-máyv.

Sun-flower, Hvsé-vhákē.

Sun-rise, Hvs'e-aos'sv.

Sun-set, Ak-hv'sē.

to Sup, s. Nomélketv.

Supple, Tvhópkē.

to Supply, Svfv'cetv.

Supply with, Es-vfas'tetv.

Surcingle, Sóh-wvnákv.

Sure, Kérrē-hērē. Mehénwē.

Surely, Mehen'wvn. Mehénwusen.

to Surround, V'copóksetv. Vfúllotécícetv.

Surtout, Kápv-cap'ko.

Surveyed land, Ekvn-tv'ckv.

Surveyor, Ekvn-tácv.

Suspenders, Sóh-hvlátkv.

a Swallow, Tv'kpecúcē.

to Swallow, Nokméletv. Lóketv. Swamp, Opēlófv. A'kpēlófv.

Swan, Kok'kv.

to Swap, Setén-yopósketv. Tenyopósketv.

S'warthy, Oklánē-ómē.

to Swear, Opunv'kv-yékcen-temfv'tcetv. Trhíketv. Hocéfetv. Swearers, Tvhikv'lkē.

Sweat, Mes'kè.

to Sweep, Pasetv. Aspásetv.

Sweeper, Pásv.

Sweet, Cv'mpē.

to be Sweet, $\mathrm{Cv}^{\prime}$ mpetv.

Sweet-gum, Helúkfvmécv.

Sweet-gum-tree, Heluk-vpē.

Sweet smelling, Fvmécv.

to Swell. Hvsvf ketv.

Swelled, Wvpv'ksē. Hvsv'fkē.

Swelling, Hvsv'fkē. Hvsvfsv'kē. Swift, Vlécē. Pvf'nē. Pv'fnetá. Swiftness, Vlécv.

to Swim, Ak-omíyetv. Omíyetv. 


\section{SW I}

Swimming, O'miyat.

Swine, Suk'hv-vikè.

to Swing, Opécetv. Vyúláhletv.

Svyóklásketv.

to Swing, v. c., Svyóklasécetv.

Switch, Estep'ketv.

Swollen, Takpucécē. Hvsvf kē.

Sword, Eslaf'kv-cap'ko.

Sycamore, Ak-hv'tkv.

Syllable, Seték-vpv'kē.

Synagogue; Nakvf'tetv-cúko.

\section{T.}

Tabernacle, Es-cúko-hákv.

Table, Oh-hom'petv.

Table-cloth, Oh-hom'petv-ohpvtákv.

Table-land, Kvn-tvpéksē.

Tackling, Nak-svtot'ketv.

Tack, Vcópucē.

Tadpole, Tóky îlkv.

Tail, Hv'cè.

Tailor, Ahórv.

to Take, Es'setv. Cáwetv.

go and Take, Róh-hvlátetv.

Take account of, Tem-fv'tcetv.

Take all, Omvlécetv.

Take by force, Yékhécetv.

Take away, Akonv'hetv.

Take corn out of mortar, Wulécetv.

Take down, Lekv'petv.

Take from, En-cáwetv. Kónetv.

Take heed, Vkëtécetv.

Take in, Enyvpóyetv.

Take off, Róketv.

Take off coat, Kápv-róketv.

Take off shoes, Téfetv.

Take out, Aóssícetv. Aswolkúecetv.

Take out, As-sóssícetv.

to Take thought, Vkérrícetv.

to Take up, Tv'k-es'setv.

to Take with, Evpáyetv.

\section{TAL}

Tale, Nak-onv'kv.

Talent, (about \$1,645) Tálvn。

Talk, Punv'kv. Opunv'kv.

to Talk Punáyetv.

to go and Talk to him, Rénpunáyetv.

Talker, Opunáyv. Punáyv.

Tallow, Wákv-nēhá.

Talons, El'lē-wēsákv

Tame, (animals) Yvmv'sē. Vpúckv. Yv'kyēpá.

to Tame, Yvmv'setv. Yvmvsícetv.

to Tan, Cússē-háyetv.

to Tangle, Téyékcetv.

Tanner, Cus'sē-háyv. Nákhv'rpēcatécv.

to Tap, Cēfokkícetv.

Tape, Takfúlwocē.

Tar, Culok'cuwv.

Tarantula, Acukrvn'wv-rak'ko. to be Tardy, Púlsetv, Vcēwécetv. Tardy, Pul'se. Vcéwē.

Tares, Teleko-vhákē.

Target, Sat'kv-etcétv. Cv'sketa.

Tartar-emetic, Svwotkv-hëles'wv.

to Tarry, Vcēwicetv. Fēkhúnnetv.

Task, (day's work) Sátkv.

Tassel, Mokmérikè.

to Taste, Lásetv. Láhsetv.

to Tattle, Nak-óketv.

Tattler, Punv'kv-sulkv.

Taverner, Cúko tvl'emē-háyv.

Tea, Vs'sē.

Tea-cup, Sésketúcē.

Tea-kettle, Uéwv-esmorec'kv.

Tea-pot, Vs'sē-vcrn'kv.

Tea-saucer, Sesketúcē-empvtákv 。

Teaspoon, Hak'kucē.

Teaspoon, (big) Hákkv-rákko.

to Teach, Mvháyetv.

'Teacher, Mvháyv.

Team, (for wagon) Wákv-vtot. kv'lkè. 


\section{TEA}

to Team, (pour in) Oh-crn'etv. Teamster, Scvlec'kv-toh'kv.

to Tear. Sétetv, Cétv'ketv, Etesétketv.

Tears, Túhropúswv. Opúswv. to Tease, Naorícetv. Vrusáyetv. Teat, Pes'sē.

Tedious, Pul'sē.

to Tell, Monáyetv. Onáyetv.

to Tell a lie on one, Oh-lak'setv.

to go and Tell him, Rém-onáyetv.

Teller, Punáyv.

Temperance, Uehómē-es'ketvwíketv.

Temperance man, Uehómē-éskeko.

Temperate, Hacēkót. Eskēkót. to be Temperate, Uehómē-eskēwíketv.

Tempest, Hvnv'cvfélv.

Temple, Hatkv-ces'kv.

Temple, Cúkn-vcákē.

to Tempt, Vnrápetv. Eskérretv.

Temptation, Vnrápkv.

Tempter, Vnrápv.

Ten, Pálen.

Tender, Lowac'kē.

Tender-loin, Era-v péswv.

to Tend, Oh-afvs'tetv.

Tent Es-cúko-hákv.

Tenth, Espálat.

Tepid, Lekhúsē.

Terraced, Cékhē.

Terrapin, Lócv-tvkoc'kē.

Terrible, Sehonec'kē.

to Terrify, Penkvlécetv.

Testament, (New) Nakcókv-múcrsē.

to Testify, Em-onáyetv. Aénkérretv.

to Testify, Akērkúecetv.

to Testify, Akërkuecvketv.

to Testify, Oh-kērkúecetv.

Testimony, Es-en-kerkuéckvn.

\section{TES}

Text, Opunv'kv-yvlúnkv. $\mathrm{Yv}_{\mathrm{v}}$ lúnkv.

Than, Sen.

to Thank, Akvsv'metv.

Thankful, Akvsámē.

Thankless, Akvsv'mekó.

'Thanks, Akvsv'mkv.

That. Momát. Ma, Mv.

That, Mómat.

That-way, Vsíma.

to Thaw, Kvf'etv. Kvfkétv.

Thee, (or you) Cémē. Cè. Cem. Them, Ma, Mv, Em, E.

Then, Moh'men, Mómof, O'mof. Thence, Rés.

Theology, Hesáketv mese-en-kerretv.

There, Mv'n. V'svn. Mimvt.

There, Mímv. Min.

to be There, Róretv.

There may be, Vtéhkē-wítes.

Therein, V'sv-ófvn.

There is, Sásé.

Therefore, Múnkv. Munkv'h. kvn.

The self same day, Mv-néttvmáhusat.

Thick, Cékfē. Cékfvkē.

Thick, (very) Chékfē-herē.

to be Thick. Cékfetv.

to Thicken, v. c., Cekfícetv.

to Thicken, Cek'fetv.

Thicket, Hv'fvpan.

Thief, Horkópv.

to Thieve. Horkópetv.

Thievish, Horkopv'rē-ómet.

Thigh, Hv'fē.

Thigh-bone, Hv'fē-fúnē.

Thigh, (front part) Cvnáksē.

Thimble, Estenk-svhēpakkv.

Thin, (as cloth) Tv'skuce.

Thin, (as liquid) Remhē. $\mathrm{KV}$ = sv'mrē.

Thin, (a little )Kvsv'mrusē. 


\section{THI}

to Thin, Kvsvmrécetv.

Thing, Nákē. Nák.

to Think, Vkerrícetv, Kómetv.

to Think on, Oh-vkērrícetv.

Thinker, Vkērrícv.

Thirdly, Svtucénat.

Thirst, Wvnh'kv.

to Thirst, Ewvnh'ketv.

Thirsty, Wvnh'ke.

Thirteen, Pálen-tutcénóhkáken.

Thirty, Palē-tutcénen.

This, Héyv. Yv.

This day, Mucv-nét'tv.

This is all, Mómosē.

This night, Múcv-nérē.

This place, $\mathrm{Yv}^{\prime} \mathrm{mv}, \mathrm{Yvn}$.

This side, (of a river) Atvpála.

Thistle, Vkácv.

This way, Yv'min. Yv-mímvn.

Thither, Mv-áyetv.

Thorn, Eto-fv'ske.

Thorny, Eto-fv'skē-v'lkan.

Thought, Vkerríckv.

Thousand, Cúkpē-rákko.

Thread, Afúswv.

Three, Tut-cénen.

to Thresh, Cēsv'pketv.

Threshed-out, Cèsv'pkē.

Th eshing-floor, F'ettv-tvpéksē. Nērkv-en-césketv.

Thrice, Tutcénv.

Throat, Nok-féhpv .

to Throb, Tv'mh-tóketv.

Through, Tēropóttē. Rvpóttē.

to go Through, Tèropóttetv.

to put Through, Téropóttécetv.

to Throw at, Afv'letv.

to Throw against, Akv'letv.

to Throw away, Awíketv. Akáyetv. Apvlv'tetv.

to Throw from, Ak-áyetv.

to Throw over from, A-oh-wvlv'phúecetv. A-oh'-wvlv'pēcícetv. to Throw this way from, Awíketv.

\section{THR}

Thrown, Svfv'lkē.

Thrush, (a bird) Trlókkē.

Thrust in, (grafted) Vsékkē.

to Thrust in, Vsekkéyetv.

Thumb, Enkē-etskē.

to Thump with nail, Kófnetv.

to Thump, Témhtécetv.

Thunder, Tēnétkē.

to Thunder, Tenétketv.

Thursday, Rv'stē. Nvr-kv'pvenhiyv'tkè.

Thus, Hiyómen. Hiyón. Hvmónt.

Tick, (insect) Ef kv'nco.

Tick, (seed) Ëfkv'ncocē.

to Tickle, Encékcécetv.

to Tickle with the hand, Enkecècélketv.

Tide, Ue-aláka. Wealáka.

Tidy, Hērusē.

to Tie, Wvnáyetv. Es-wvnáyetv.

to Tie, Wvnawicetv.

to Tie with, Ras-wvnáyetv.

Tied, Wvnáké.

in Tiers, (ranges) Tvlálvkē.

Tiger Kátcv.

Tight, Yvnv'fkē. Yekcē.

to Tighten, Yékcícetv.

Till, Mun'ken.

to Till, Lúyetv. Laúwetv.

Timbers, Eto-súlkē.

Time, Okétv.

Timothy-grass, Pv'hē-okholáttē.

Tin, Palvk'nv-es-háyetv.

Tin cup, Hálo.

To be so, Mómetv.

to Tingle, Sv'mvmak'ketv.

to Tinkle, Cvmh-cákv-háketv.

Tin mine, Palvk'nv-esháyetv. enkor'kv.

Tinner, Palvk'nv-háyv.

Tin-pan, Hálo-palv'knv.

Tin-ware. Palvk'nv-eshákv.

Tip-end, En-yúklowákē. 


\section{TIP}

Tipsy, Mahyum'kē.

to Tire, v. c., Hotosícetv. Vkv'nsvwécetv.

Tired, Hotóskv. Hotósē.

to be Tired, Hotósetv. Hotosáketv.

To, Etóh. Rórē. Soh.

Toad, Supak'tv.

Tobacco, Hécē.

Tobacco-pipe, Hécē-pv'kwv.

Tobacco-worm, Hécē-pápv.

To-day, Múcv-néttv.

Toe, Elle-wesákv. Lēwesákv.

Toe, (great) Ellè-étskē.

Toe, (little) Ellē-wēsákucē.

Toe-nail, Ellē-kosósvwv.

Together, Vpáken.

Together, Etóh. Tohkv'lkē.

Together, (in a heap) Copáksē.

to get Together, Tohkv'lketv.

Together with, Svpáken.

Esyónat.

Token, Eskérkvt.

Tomahawk, Pucúswvcē.

Tomahawk-pipe, Pucús-hécēp'vkwv.

Tomato, Tomáto.

Tomb, Cvttokófkè. Hopélkv.

To-morrow, Rem-páksē. Pak'sē.

Vpáksē.

day after To-morrow, Páksēvsímv.

Tongs, Sáwekkel'kv.

Tongue, Tulas'wv.

Tonic, Hom'petv-en-cvmpec'kv.

Tonic, Heles'wv-esyekcícetv.

To-night, Múcv-nērē.

Tool, Es-háyetv. Es-hákv.

Tools, Sa-v tot'ketv.

Too much, Sen-súlkē.

Too thick, Sen-cékfē.

Tooth, Nutē.

Toothache, Nútē-nok'kē.

Tooth-brush, Nutē-espáskv.

\section{TOO}

Tooth, (double) Nutē-rak'ko.

Tooth, (eye) Nute-fvs'ke.

Tooth, (fore) Nutē-hómv.

Tooth-pick, Nute-sem-fulletv.

Top of the head, Ekv-onv'pv.

Torches, Eto-kulēcv'kvten.

Torment, Estèmer'ketv.

to Torment, Estēmérrvkúecetv. Estemérrícelv.

Torn, Set'kē, Cetv'kkat.

to Toss, Svfvl'etv.

Tossed to and fro, Fvllehólē.

Total, Omvl'kv.

to Touch, Acēláketv. Cēláyetv.

Cēlayáketv. Técēláyetv.

Touching, Hérkuecáton-ómat.

Tough, Tvlv'swe.

to Tow as a boat, Ak-hvlátetv.

Towards, Oh-fv'tcv. Er.

Towel, Estēturóf-eshvsvtec'kv.

Town, Tvlófv. Tv'lwv.

Town-crier, Tvhpálv. Tólkvtècv.

Trace-chains, Cvto-telácv.

to Trace, El'len'-tétv.

to Track, Ellen'tetv.

Tracking, Hénwē.

to Trade, Es-nes'setv. Tennéssetv.

Trader, Nak-wíyv. Es-nésv.

Trading-house, Néskv-cúko.

to Traffic, Es-nes'setv.

to Trail, Ellen'tetv.

Traitor, Oh-ker'kúeckv.

to Trample, Oh-svpv'kletv.

to Trample on, El'le-ecic'v-háyetv.

to Transgress, Tóhwvlv'pketv.

Transgression, Naor'ketv.

to Translate, Tóhtvilhuécetv.

Oh-tvlēcícetv.

Translation, Tóhtvlhúẻckv.

Translator, Tóhtvlhuecv.

to Transplant, Rvfécetv. 


\section{TRA}

Transplanted, Rvt'kē.

to Trap, En-kun'hetv.

Trap, (steel) Svkkēpuéckv.

to Travel, Ar'etv. Weláketv. Fúlletv.

Traveler, Ayv. Cunéckv.

Travelers, Cunēckv'lkē. Fullv'lkè.

Tray, Vcvlvp'etv-vtēh'kv.

Treacherous, Mvker're.

Treacle, Púncè.

to Tread, Oh-huéretv.

to Treasure up, Sulécetv.

Treasure, Nak-sulécetv. Vtéh$\mathrm{kv}$.

Treasurer, Cvtokunáwv-hēcícv.

to Treat, Hēren-afvs'tetv.

to Treat with disrespect, Emmoskómeko-áretv.

to Treat with deference, Vcayécetv.

Tree, Eto.

Tree-toad, Wela-tvk'kv.

Tree-top, Etó-yuk'sv.

to Tremble, Fēkek'etv.

Trembling, Fēkékusē.

to Trespass, Mvttecícetv. Vnaor'ketv.

Tribe, Tvl'wv. Celókhókv.

Tribulation, Estēmérkv.

Tribute, Ekv-fēkétv.

to Trick, Sák-hopv'netv.

to Trim, Ahērícetv.

Trimmed, Svtáhē.

to Trot, Cvmp-cóyetv, Latéketv.

Trouble, Naor'kv.

to Trouble, Naorícetv.

to Trouble one's self with, Sēnaorícetv.

Troubled, Fēkhērí-cekon.

to be Troubled, Naorv'ketv.

Troublesome, Naorícē.

Trough, Per'ro.

Trout, Cálo.

\section{TRO}

Trowsers, Vtekpíkv. Hv'tekpíkv.

Trucks, Eto-scvllec'kv.

Truck-weels, Eto-sencvl'la.

to be True, Mehénwetv.

True, Mehen'wē. Mehénwusē.

Truly, Fátcusen. Mehénwv.

Trumpet, Pof'ketv. Féhpv.

Trunk, Aháwv.

to Trust on, Afēkrak'ketv.

to Trust in, Enhónretv.

to Trust to, Em-enhon'retv.

Trustee, Em-wíketv.

Truth, Mehen'wv. Ehénwv.

to Try, Eshécetv.

Tub, Sokos'etv-tomótké. Etomútkē-svkóskv.

Tuesday, Tústē. Mvn'tē-enhíyvtkē.

Tulahassee,(old town) Tvlvhássē. Tulsa, (name of a town) Tvlsa.

to Tumble, El'len-tap'petv.

Tumbler, Ses'ketv.

Tumult, Yíyetv.

Tune, Es-yvhíketv-en-hákē.

Turban, Núckv-rak'ko.

Turbid, Aklowáhē.

Turkey, Pen'wv.

Turkey-beard, Penwv-entówē.

Turkey-hen, Pēnétskē.

to Turn, Fulot'ketv.

to Turn around, Afu-lótetv.

to Turn aside, Fíketv.

to Turn away, E-en-kvpíyecícetv.

to Turn back, Ráful'ketv. Erfúlketv. Fúlketv, Fulhóketv, Fullécetv.

to Turn in, Es-cēyícetv. Escēyv'ketv.

to Turn inside out, Rvtv'kféletv.

to Turn the head one side, Kvnek'setv.

to Turn one's self, Afulot'ketv.

to Turn out, v. c., Ossícetv. 


\section{TUR}

to Turn out, Wulhúecetv.

to Turn over, Rvkpv'lketv.

to Turn round, Fulótketv.

to Turn somersault, Hv'kvn-cellē-potketv.

to Turn under, Rvkpv'letv.

to Turn up, Vkéfetv.

to Turn down, Potúecetv.

Turned to one side, Pucéksē. Fiyv'tkē.

Turned at the edge, Penútkē.

Turnip, Tvnvp'se.

Turnip-seed, Tvnv'psē-enérkv.

Turpentine, Colok'crwv.

Turtle-dove, Pvc'è-hówē.

Turtle, Trkók-fv'mpē.

Turtle or tortoise, Lóca.

Turtle, (thin shelled) Holak'wv.

Turtle, (crying) Lóca-huéhkv.

Turtle, (snapping) Lóca-yékcv.

Tusk, Nùtē-rak'ko.

Tuskegee, (name of town) Tvskēkē.

Twelve, Palen-hókkolóhkáken.

Twenty, Palē-hokkólen.

Twenty-five cents, Kvn-sátkvhv'mken.

Twice, Svhokkólat.

Twig, Lvtcúcē. Vhos'wucē.

Twilight, Yomùckusē.

Twin. Póktv.

Twine, Fv'kkucē. Es-wvnákv.

to Twinkle, Wécwéyetv. Yefyéyetv.

to 'Twist, Téfvllv'pketv. Fvllvlícetv. Hon'rētv.

to Twist, Tépvllv'yetv. Honóyetv. Fíyetv.

Twisted, Opíkē. Fíkē. Fiv'llv líckv.

Twisted together, Tēfvkyv'tkē.

Twisty, Fvlléknē.

Two, Hokkólen.

Tying-snake, Estvkwvnáyv.

\section{UGL}

U.

Ugly, Holwákē, Hērúseko.

Ulcer, Okosómē. Lēcē.

Umbrella, Seko-hvpettic'kv . Vpèttickv.

Unbelief, Akvsv'mekó.

Unbelievers, Ak'vsvmv'kokvlkè.

to Unbuckle, Rēcópetv.

Uncertain, Ker'kemáhekó.

Uncivil, Hoporrénē-máhekó.

Uncivilized Nákē-ker'rekó.

Uncle, Paúwv. Er'kucē.

to Uncover, Enrámetv. Rámetv.

Uncovered, Tvn'kē. En-rvm'kē. Unction, Essíyetv.

Undefiled, Es-vhólwákekó.

to be Under, Ellécetv.

Under, Ellécv. Ra-enkvncápat. Underclothes, Ofv-v'tcetv.

Underneath, Ellécv.

a little Underneath, Ellécusan. Ellécusē.

to Understand, Ker'retv.

Undone, Recvp'kē.

Undoubted, Fvt'cv-hērē.

Undoubtedly, Fvt'cv-hērē.

to Undress Rókróyetv.

Undue, Enhec'keko-táyē.

Uneasy, Fekhúneko. Kósvpē.

Uneven, Semúntviē. Semúntvlv'kē.

Unfaithful, Hēromekó.

Unfinished, Espóheko.

Unfit, Eme tetáyeko.

to Unfold, Rvtosécetv.

Unfolded," Rvtos'kè.

Unfortunate, Em-vnvc'keko.

Unfriendly, Hërkeko.

Unfruitful, Ettv'keko.

to Ungird, Fecópetv. Recópetv. 


\section{$\mathrm{UNH}$}

Unhappy, Afvc'keko.

to Unite, Em-es'setv.

Unknown, Kērkeko.

Unlawful, Vhákv-tóko.

Unleavened, Tok'seko.

Unless, Mun'ko-nómat.

Unlevel, Fvléknē.

Unlike, Ahakeko. Un'ko.

to Unload, Trnecícetv.

Unlucky, Em-vnvc'keko.

Unquenchable, Vs'lekon. Vslécekon.

to Unravel, Fep'etv.

Unrest, Fēk-húneko.

Unripe fruit, Konv'khocē.

Unsound, Trrókwē.

to Untie, Recópetv.

Until, Mun'ket. Or'en. Ate. Múnken.

Unto, Oh-fvtcv. Etóh. Rórē.

Untrue, Mehen'weko.

to be Unwell, Púlsetv.

Unworthy, O'reko.

to Unyoke, Moh-tvkhákv-émes'setv.

Up, Hvl'wē.

Upon, Onv'pv. Oh-onv'pv. Oh. Upon us, Epóh.

Upright, Lvpútkè. Lvpúntkē.

Uproar, Fēk-sumécv.

to make Uproar, Fēksumécetv.

to be Upset, Hakcēlopótketv.

Upstairs, Oh-tíhē.

Up Stream, V'repv.

Upward, Hvl'wē.

to Urge, Em-vcah'netv.

Us, Pumē. Epúmē. Pum. $\mathrm{Pu}$.

to Use, Es-oc'etv.

in Use, Sémvníckv.

Usury, Hon'tv. Oh.hóntv.

Utensils, Nak-escēlákv.

to Utter, Máketv.

\section{$\mathrm{VAC}$}

\section{V.}

Vacant, Tvn'kè.

to Vaccinate, Lēcekákv-sentv'cketv.

Vaccination, Lēcekákv. Séntvc'. kè.

Vagabond, Estómis-árē.

Vail, Sētentáckv.

Vain, Ehvper'kv.

Vale, Pv'nnē.

Valid, Hēres.

Valiant, F'ek-hvm'ke.

Valise, Sohwēlep'kv.

Valley, Pvn'nē-suf kē. Pv'nnë.

Valuable, Enrah'kv-ócē.

to Value, Enrah'kv-háyetv.

to Vanish, Vr'vnáketv.

Vapor, Enhef'kv. Héf kē. Hopérē.

Varıety, Mvráhkv.

Various, Mvráhrv'kv.

Varnish, Holocic'kv.

to Vary, Témvrah'ketv.

Vast, Rak'kē.

Vat, Vcv'nkv.

Veal, Wakucē-vpes'wv.

Vegetable, Nak-lókcucē.

Vein, Catē-fvk'v.

Venereal, (disease) Mvkánē.

Vengeance, Estemérkv.

to take Vengeance, Este-merícetv。

Venison, Eco-vpes'wv.

to Venture, Ekvsvm'etv.

Verbal, Es-opunáye.

Verdant, Lánē.

Verge, (border) Vtékē.

to Verge, Vteken'yetv.

Verily, Mehen'wv.

Mómes.

Mómvrēe.

Vermilion, Cátē-ómē.

Verse, Sētemwar'kucē.

to be Very great, Svhēremáhetv. Very, Máhē. Tvts. Ta. Máhusē. 


\section{VER}

Very good, Svhēremáhē.

Very far, Hopíyetá.

Very much, Sul'kē-máhē.

Very soon, Acēhwósekon.

Very true, Mēhénweta.

Vessel, (for water) Vcvn'kv.

Vessel, (not for water) Sákkv. Vtéhkv.

Vessels, Eséss'etv.

Vest, Svk'pv-séko. Kápucē.

Vexed, Eles'kē.

Vial, Fvláskucē.

Vice, (a tool) Svweker'kv.

Vice, s., Hólwayec'kv. Naor'ketv.

Victory, Ohvn'ketv.

Victuals, Hom'peta.

to View, Hécetv.

Vigilent, Vketécē.

Village, Tvlófucē.

Vine, E-fv'kv.

Vinegar, Uetok'sē.

Vineyard, Pv'rko-cvpofv.

Violin, Hayéckv.

Viper, Acen'tv. Eketnv.

Virgin, Hoktúcē.

Virgin, Hok'tē-hunvn'wv-ker'retvsekót.

Virtue, Sērákketv.

Virtuous, Efvtcéce.

Vision, Nakhē-cihócat. Senhéckē. Es-hécetv.

to Visit, Yēhécetv. Cuko-péretv.

a Visit, Cuko-pérv.

Voice, Huehketv. Punv'kv-enhákē.

Volcano, Ekvn-hvl'wē-nekr'v.

a Vomit, Vwótkv.

to Vomit, Svwótetv. Vwótetv.

to Vomit again, Res-vwótetv.

to make Vomit, Vwotícetv.

Vomiting, Vwótet.

Voracious, Anok'sē.

Vow, Em-ēwíketv.

\section{WAD}

\section{W.}

to Wade, Ak-áyetv.

Wafer, Sételokpic'kv.

to Wag the tail, Fvnáyetv.

Wages, Estem-féketv.

Wagon, Escrléckv. Escv'la.

Wagon-bed, Es-cvléckv-pérro.

Wagoner, Escrléckv-toh'kv.

Wagon-road, Nénnē-páskv. Nénnē-rákko.

Wagon-whip, Rota-kúeckv-rak'ko Wahu, (a tree) Afúslēpákfv.

to Wail, Hih'ketv.

Waist, Ena-tetáckv. Ete-táckv.

to Wait, Eháketv.

Wait awhile, Hv'tetvs.

Waiter, Oh-vfástv.

Waiting, Ehaket.

to Wake, v. c., Ahonēcícetv.

to Waken, Ahonécetv.

to Walk, Yvkv'petv.

to Walk in, Ayvkv'petv.

to Walk with a cane, Etékkéyetv.

Walking, Yv'kvpákē.

Wall, A-tohópkè.

Walnut, Vhah'wv-enlókcē.

Walnut-tree, Uhah'-mvpē.

to Wander, Ehósetv.

Want, Kvsápkv.

to Want, Eyácetv. Eyacáketv.

War, Hórrē. Tepókv.

to War, Hor'retv, Ten-hórretv.

War-clan, Kepáyv.

Warm, Hiyē, Hiy'usē, Lekúthē.

to be Warm, Hiyetv.

to Warm, Hiyécetv.

to be Warm, Vlekúthetv.

to Warm one's self, Tvl'retv. Tvlrépetv.

to Warm slightly, Lékhícetv.

to Warn, Em-onáyetv.

War-name, received, Tv'sekíyv. 


\section{WAR}

Warrior, 'Tv'stvnvk'kē.

Warriors, Tv'stvnvk-v'lkē.

Wart, Tokfélv.

to Wash, Ok.kósetv.

Wash-basin, Estē-toróf-palv'knv.

Washington, Wácēnv.

Wash-tub,'Tomút'kēenak-svkóskv

Wasp, Focátē, Fayépv.

Wasp, (black) Fo-hvtép-lv'stē.

Wasp: (red) Fo-cátē.

Wasp, (striped) Fo-sapsáwv.

Waspish, Focátē-omē.

to Waste, Yv'mahécetv. YVmah'ketv.

Waste, Yvmáhkē. Yvmahkúe$\mathrm{cr}$.

Wasteful, Yvmáhkē.

Waster, Yvmahéckv.

Watch, Hvsē-vker'kucē.

to Watch, Vkētécetv. Vhēcícetv.

Watchful, Vkētécē.

Watch-maker, Hvsē-vker'kv-háyv.

Watchman, Ahēcicv, Vkētécv.

Water, Uéwv. Okè.

Water-birch, Ak-cēcvláskv.

Water-bird, Ue-fúswv.

Water-basin, Akúlhē-uewv. Vlēkúthē.

Water-course, Ue-en-fih'nē.

Waterfall, Ue-oh-kálv, Ue-a-ohlátkv. Ue-oh sóhkat.

Water-gruel, Sáf kē-hákv .

Watermelon, Cv'stvlē.

Water-pail, Ue-es-cv'nkv.

Water-snake, Ue-ak-cétto.

Water-terrepin, Tvk-ok-fvm'pē.

Wattle, Nak-vtar'kv.

to Wave, Mēloh'letv.

to Waver, Yvnáhetv.

Waves, Ue-mëloh'lv.

Mēróh-

ketv.

Wax, Es-yēkcic'kv.

Wax, (of ear) Hv'cko-fvlówv.
WAY

Way, Nennē. Ay'etv.

We, Púmē, Pum, Pu.

Weak; Yékcekó. Alv'skē.

Weak in the back, Yekóte.

Weakness, Ehaper'kē. Alv'skē Wealaka, Ue-aláka.

Weaithy, Nak-ócē.

to Wean, Epes'se-wicécetv.

to Wear, Vt'cetv. Rolv'kketv.

Weariness, Hotóskv.

Weary, Hotosē.

to be Weary, Hotósetv. Enkvsv'mketv.

to Weave, Tar'etv.

Weaver, Tárv.

Wedding, Etepáyetv.

Wedge, (iron) Cv'to-fvs'ke.

Wedge, (wood) E'to-fvs'kē.

to Wedge. Sémvyékcícetv.

Wednesday, N'et'tv-cákucē-ennvrkvp'v.

Weed, Vtvk'rv. Ossvk'wv.

Week, Net'tv-cákucē.

Weekly, Net'tv-cákucē-omvl'kvn.

to Weep, Hvkih'ketv.

to Weep over, Oh-hvkih'ketv.

Weevil, Vcē-suklícv.

to Weigh, Svtáretv.

to Weigh, (hang) Vtar'ketv.

to Weigh, (v. c.) Vtarkuécetv.

Weight, Svtar'kv.

Well or spring, Uekíwv. Ue. enkórkv.

Well, (in health) Cvfek'nē. $\mathrm{Cv}$ féncv'kē.

to be Well, Cvfek'netv. Cvfén. $\mathrm{cv}^{\prime}$ ketv.

Well-digger, Ue-enkor'rv.

Well-known, Ker'kusē.

Well-water, Ueki-uéwv.

Wen, Tokfélv.

West, Hrsvklat'kv. Aklátkv。

Wet, Lvc'pē. Lv'cpetv.

Wet (very) Lv'cpetá. 


\section{WET}

to Wet, v. c., Lvcpēc'etv.

Wetumkē, Uetv'mkv.

Wewohkv, Uewóhkv.

Whale, Ue-pof'kv. Rv'ro-rákko. What? Estómen? Náken?

$\mathrm{Hi}$ ?

What I do, Nakē-moméciyat.

What is it? Nákete? Hi?

What manner of, Estómetvt?

Wheat, Télēko.

Wheat-bread, Télēko-tvklíkē.

Wheel, Em-fulótkv.

Wheel, (of wagon) Escvlec'kven-cvllv.

Wheel, (fore) Escvlec'kv-en-cvllvhómv.

Wheel, (hind) Escvlec'kv-en-cvllv-yúpv.

Wheel, (spinning) Esfv-léckv.

Wheel-band, Esfvléckv-en-fv'kv.

When? Estófvn?

When, Ofv, Of, Hiy'omófvn.

When it is thus, Momófvn.

Whence? Estv'mvr'vtet? Estómet?

Where? Es'tvmvn? Es'tvn? Estvmin? Estv'mvto? Estómen?

Wherefore? Mómekv?

Wherein, Es'tv'mv-máhusat.

W'heresoever, Estv'mvto-estó. men.

Whereupon, Momáten.

to Whet, Mvsáyetv.

Whether, Mómē-estómis.

Whet-stone, Cvto-es-fvséckv.

Which? Estóma?

Which of you? Estomátskat?

Which way? Estómin? Estómvte?

While, Mómof.

to Whine, (as a dog) Cókcóketv. a Whip, Es-tépketv. Rotákkuéckv.
WHI

to Whip, 'Tep'ketv. Rokáfetv.

to Wnip in water, Ak-tépketv.

to Whip at, Atépketv.

Whip-lash, Sen-yúk-fv'nkv.

Whipping, Rókáfkv.

Whippoorwill, (Dutch) Cuk'-pèlapélv.

Whipstock, Rotákkúeck-vpē.

Whirlpool, Uefulót'kv.

Whirlwind, Hvnv'cvfélv.

Whiskers, Cuk-es'sē.

Whiskey, Uehómē. Wéskē.

to Whisper, Wvswáhetv.

to Whistle, Fol'ketv.

White, Hvt'kē, Hvthv'kè.

White-ash, Etó-hv'tkē.

White corı, Vcē-hv'tke.

White-headed, Kvhv'tke.

White man, Es'tē-hv'tkē.

to Whiten, Hvtécetv.

to Whiten, v. c., Hvthic'etv.

Whitish, Hv'tkusē. Okhv'twē.

Whithersoever, Estv'mv-estómet.

Who? Estímvt? Nv'pv? Mv?

Whoever, Estímvto-estómet.

the Whole, Fulle. Omv'lkvt.

Whole, (sound) Temvpókē.

Whom? Estómet?

to Whoop, Pih'ketv. Hah'ketv.

Whooper, Pihkunáyv.

Whooping-cough, Ohóketv-hok'ho.

Whose? Estímv?

Why? Estómen?

Wicked, Naorícē. Holwayéce.

Wickedness, Naor'ketv. Hol-

wayec'kv.

Wide, Tap'hē. Tap'hetv.

Wide mouthed, Wehv'klē. Weléksēe. Wehákē.

to Widen, Taphuécetv.

Widow, O'ye.

Widows, Oyēhákat-oyēv'lkē. Hoktv'kē-oyev'lkē. 


\section{WID}

Widower, O'yē.

Wife, Híwv. Ehíwv.

Wig, Têwv-tvrkē.

Wiggle-tail, Akwéna-hak'usē.

Wild, Seminólē. Honēcē.

Wild-cat, Kowákucē.

Wilderness, Vnráwv.

Wild indiroo, Cv'svsákv-rak'ko.

Wild potatoe, Alún-áhá. Ahvlwv'nv.

Will, Kómatē.

Willow, Ahwánv.

Willow, (weeping) Hóyvnécv.

to Win, Epóyetv.

Wind, Hótvlē.

to Wind, Hotvl'etv.

Winding-sheet, Estē-ēlē-vtc'etv.

Window, Aháukucē.

W'indow-curtain, Aháukucē-ohrvnkv.

Wind-pipe, Nokfeh'pv.

Windy, Hotv'letv.

Wine, Uehómē-cátē.

Wine-glass, Uehómē-cátē-ses'ketv.

Wine-press, Uehómē-cátē-vcrn'$\mathrm{kv}$.

Wing, Trr'pv.

to Wink, Mosúlletv.

Winter, Rvf'o.

to Wipe, Hv'svtēc'etv.

Wiper, Es hv'svtec'kv.

Wire, Cvto-lowákē.

Wisdom, Hóporen'kv.

Wise, Hoporēnē, En-hoporénkvhv'ttē.

to be Wise, Hoporēnetv.

to Wish, Eyácetv. Kómetv.

Wit, Hoporénkv.

Witch, Por'rv. Estem-por'rv.

Witch-craft, Por'retv.

With, Esyómen. Es. Sē. Sem. Sen. Sv. Svc. Svn. Svm. Tem. Ten. Vpákē.

\section{WIT}

With them, Esyómat. Esyúnt. to be With, Vpáketv. Vpúlkety. to be With child, Nv'rkésetv.

to Wither, Yuknépetv.

Withered, Yúknē.

Withers, E-ful'owv.

Within, Orófvn. Vpíkēe. Of'v.

Nvthófv.

to be Within, Epíketv.

With men, Séstem.

With the law, Sem-vhákv.

With you, Sècē.

Without, Topv'rv. O'nvpr.

Without cause, Hopánē-sēkón.

Witness, Enkérkv. Kerkuéckv.

Akērv.

Witnesses, Enkerv'lkē.

Wizzard, Pórv-hunvn'wv.

Woè, Holwákvkēs.

Wolf, Yáhv. Lētéf'kv. Emas'kv.

Woman, Hok'tè.

Womb, Hopúetak-hútē.

Women, Hoktv'kè.

Wonderful, Estómáhē. Sēho-nec'kv'kè.

Wonder at, Estomáhetv.

Wonders, Sēnhonéckvkē.

Wood, Eto.

Wood-chopper, Eto-cv'skv.

Wood-cock, Wáhwvk'wv. Tetkv.

Wood-pecker, Cvkvlá.

Wood-pecker,(speckled) Cáhcvkwv.

Wood-pecker, (large yellow) Tvr' pv-lánē. Fètak'e.

Wood-pecker, (red head) Tet'kv. Wood-pecker,(sap-sucker)Tvs'kē Wood-worm, Ewakútv.

Wool, Cufē-es'sē. Yvpefík-éssē. Woolen-cioth, Cúfē-es'sē-vpákē. Wooly, Pecéhē, Pecēcékúsē.

Word, Punvk'v. Opunv'kv. Onv'kv.

Work, Vtot'ketv. 


\section{WOR}

to Work, Vtót'ketv.

to Work, (with) Sv-tótketv.

to Work, (hard) Yékcē-vtotketv.

Work-bag Nak-vteh'kv.

Work-bench, Etó-oh-kvlif f'etv.

Worker, Vtót'kv.

World, Ekv'nv.

Worm, Cun'tv. Lvpúlvpú.

Worm, (cut) Opúrkv.

Worm, (grub) Yvl'v.

Worm, (hairy) Sukeh'tv.

Worm, (hairy-stinging) Estē-tvlákv.

Worm, (fish) Sëmakwíkv.

Worse, Sēmúntvlen. Svholwákē.

Worship, Mēkusvp'kv. Arákkúeckv.

to Worship, Mēkusvp'etv. Arákkuécetv.

Worshiper, Mēkusápv.

Worst, Sv'holwákē-máhē. Svhēremáheko.

Worsted, Cufe-es'sē-svhol'kv.

Worthy, Orv'kē. Mómvrē-tetáyē. Oreómē.

to be Worthy, O'retv.

to Wound, Vnvttēe'etv.

to be Wounded, Vnv'ttetv.

Wounded, Vnv'ttē.

Wounder, Vnỵttécv.

Wounds, Tv'cke.. Unv'tte-tv'.

Woven, Tvr'kē. Trrkv.

to Wrap up, Ayókkófetv.

to Wrap around, Apvllv'ketv.

to Wrap around, Apvllv'netv.

to Wrap around, Vtúlpóketv.

to Wrap up with, Svyókkófetv.

Wrapped up, Apvllákusē.

Wrath, Crpv'kketv.

Wrathy, Crpvkkē.

Wren, Cóhlikv. Cólowēskv. Colúehkv.

to Wrestle, Tewvkēc'etv. Cēyólletv.

\section{WRE}

Wretched, Estēmer'kē.

to Wring, Opēc'etv.

Wrinkle, Tēkel'kē. Etēkélketv. Wrink'ed Yoc'ke.

Wrist, Enkē-taklos'wv. En'ketvlos'wv.

Wrist-band, En'k-sémfulót'liv.

Wrist-joint, Tv'htek'ekv.

to Write, Vhótcetv. Hótcetv.

Hotcícetv. Cóyetv.

to Write down, Svlicetv.

Writer; Hotcícv.

Writing, Vhótcē. Hótcē. Eshótcic'kv. Cókv.

Writing-book, Eshótcíckv-nakcókv.

Writing-desk, Oh-hótcic'etv.

Writing-table, Oh-hótcickv.

Written, Cókē.

Written down, Svlúmkvkē.

Wrong, Mvt'tē. Em-mv't'te. Fv'tcekó.

\section{Y.}

Yam. A'ha-crm'pē.

Yard, (door-way or shed) Fet'tv.

Yard, (stick) Ahopákv.

Yard, (one) Ahopákv-hvm'ken.

Yarn, (cotton) Tot'kv-ful'kv.

Yarn, (woolen) Cufē-es'sé. Fv]léckv.

to Yawn, Nucáyetv.

Yè, Cémē. Cè.

Yea, Henká. Mehen'wv'.

Year, Oh.rólopē. Méskē.

Yearling, Oh-rólupē-hvm'ken.

Yeast, Es pákkuéckv.

to Yell, Pin'ketv.

Yellow, Lánē. Ok'lanē.

Yellow-corn, Vcē-lanē.

Yellow-hammer, Tvrpv-lánē. Fẽtúkkv.

Yellow-jacket, Fo-lànē. to Yelp, Moh'tvk-háyetv. 


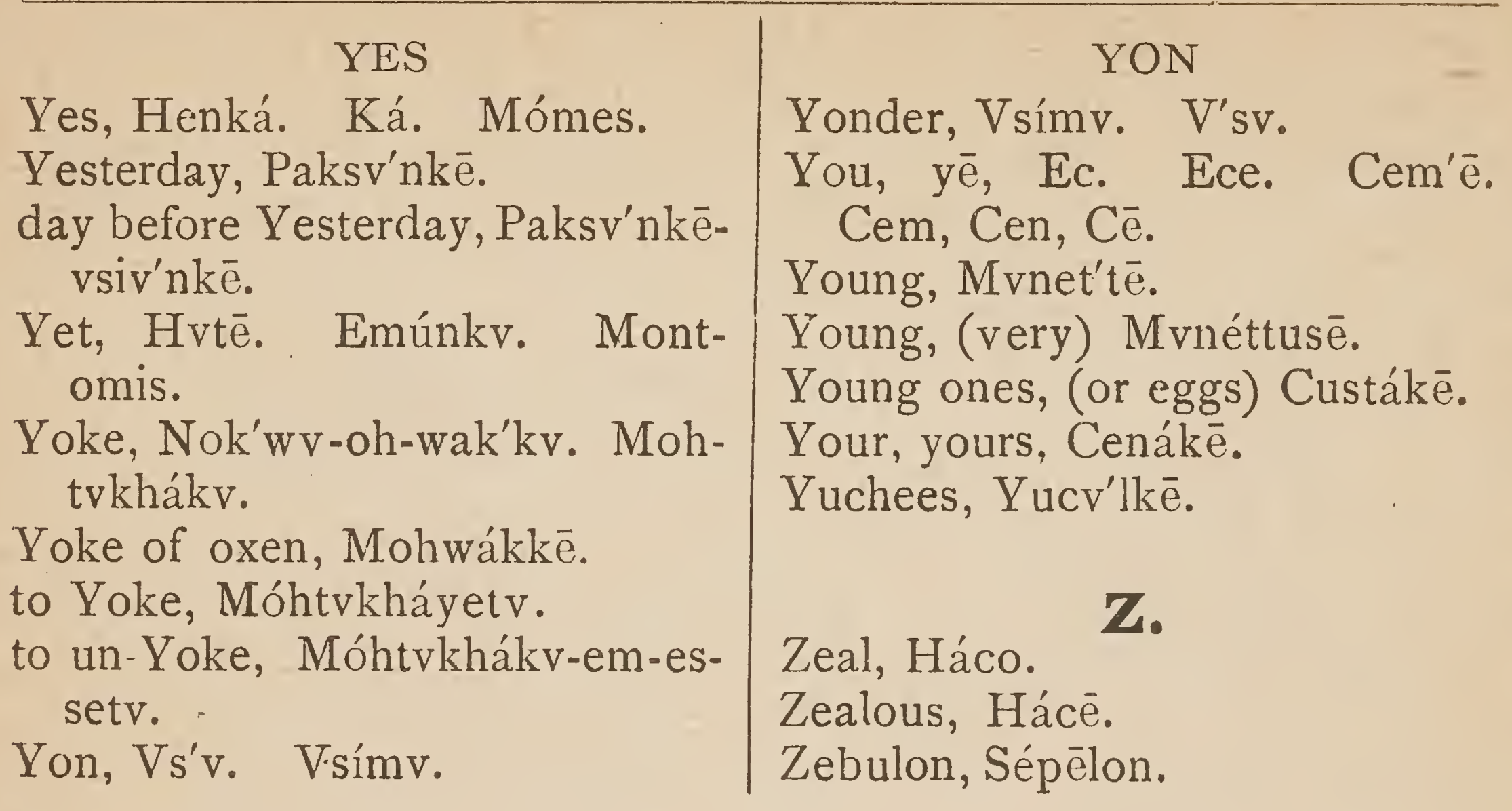

\section{NAMES OF THE MONTHS.}

I January-Rv'fo Cúsē, winter's younger brother.

2 February--Hótvlē-hv'sē, wind month.

3 March — Tasáhcucēe, little spring month.

4. April — Tasáhcē-rákko, big spring month.

5 May - Kè-hv'sē, mulberry month.

6 June - Kv'co-hv'sē, blackberry month.
7 July-Hiy'ucē, little harvest or summer.

8 August - Híyo-rákko, big harvest or summer.

9 September-Otowóskucē, little chestnut month.

Io October - Otowóskv-rákko, big chestnut month.

I I November - Ehóle, frost month.

I 2 December-Rvfo-rákko, big winter.

\section{MUSKOKEE NUMERALS.}

I.

II.

III.

IV.

V.

VI.

VII.

VIII.
I. $\mathrm{Hv}^{\prime}$ mken.

2. Hokkólen.

3. Tutcénen.

4. O'sten.

5. Cháhkepen.

6. Epáken.

7. Kúlvpáken.

8. Cénvpáken.
One.

Two.

Three.

Four.

Five.

Six.

Seven.

Eight. 
IX.

$\mathrm{X}$.

$\mathrm{XI}$.

XII.

XIII.

XIV.

$\mathrm{XV}$.

XVI.

XVII.

XVIII.

XIX.

XX.

XXI.

XXII.

XXX.

$\mathrm{XI}$.。

L.

LX.

LXX.

LXXX.

$\mathrm{XC}$.

$\mathrm{C}$.

CC.

CCC.

CCCC.

D.

DC.

DCC.

DCCC.

DCCCC.

$\mathrm{M}$.

MM.
9. O'stvpáken.

ro. Pálen.

I I. Pálen-hv'mkvntvláken.

I 2. Pálen-hókkolóhkaken.

I 3. Pálen-tutcenóhkáken.

I4. Pálen-ostóhkáken.

I 5. Pálen-cáhkepóhkaken.

r6. Pálen-epóhkáken.

I 7. Pálen-kulvpóhkaken.

I8. Pálen-cenvpóhkaken.

19. Pálen-ostvpóhkaken.

20. Pále-hokkólen.

2 r. Pále-hokkólen-hv'mkvntvláken.Twenty-one.

22. Pále-hokkólen-hokkolóhkáken.Twenty-two.

And so on.

30. Pále-tútcénen.

40. Pále-ósten.

50. Pále-cáhkēpen.

6o. Pále epáken.

70. Pále kúlvpáken.

80. Pále-cénvpáken.

90. Pále ostrpáken.

100. Cúkpē-hv'mken.

200. Cúkpē-hokkólen.

300. Cúkpē-tútcénen.

400. Cúkpē-ósten.

500. Cúkpē-cáhképen.

600. Cúkpē-epáken.

700. Cúkpē-kulvpáken.

800. Cúkpē-cénvpáken.

900. Cúkpē-óstvpáken.

1,000. Cúkpē-rakko-hv'mken.

Etc., Etc.

2,000. Cúkpē-rákko-hókkólen.

X. I0,000. Cúkpē-rákko-pálen.

XX. 20,000. Cúkpē-rákko-pálē-hókkólen. Twenty thousand Etc., Etc.

C. I००,०००. Cúkpē-rákko-cúkpē-hv'mken.One hundred

CC. 200,000. Cúkpē-rákko-cúkpe-hokkólen.Two hundred Etc., Etc.

M. 1,000,000. Cúkpē-rákko-vcúlē-hv'mken. One million.

MM. 2,000,000. Cúkp̄̄-rákko-vcúlē-hokkólen.Two million. Etc., Etc.
Thirty.

Forty.

Fifty.

Sixty.

Seventy.

Eighty.

Ninety.

One hundred.

Two hundred.

Three hundred.

Four hundred.

Five hundred.

Six hundred.

Seven hundred.

Eight hundred.

Nine hundred.

One thousand.

Two thousand.

Ten thousand.

[thousand. 



\section{DIC'TIONARY}

OF THE

\section{MUSKOKEE OR CREEK LANGUAGE}

IN

CREEK AND ENGLISH

BY

ReV, R, M, LOUGHRiDGE, D, D, Missionary,

AND

ELDER DAVID M, HODGE, INTERPRETER,

With Assistance from other Interpreters.

Red Fork, Indian Territory.

1890.

Printing House of J. T. Smith,

11 Bridge Approach, St. Louis. 


\section{MUSROKEE ALPHABET.}

A. a. always broad as in far, as aha, afke.

C. c. che for ch as ceme, Cesvs.

E. è. long as in meet, as likēs we sit.

E. e. short, as $\mathrm{i}$ in pin, as este a person.

F. f. as in English.

H. h. as in English.

I. i. always long as $i$ in pine.

K. $k$. as in English.

L. 1. as in English.

M. m. as in English.

N. n. as in English.

O. o. always long as in note, of,$o p v$.

P. p. as in English.

R. r. hle, for hl. as rvro for hlvhlo.

S. s. as in English.

T. t. as in English.

U. u. as 00 in mood, as hoktuce.

$\mathrm{V}$. v. as $\mathrm{u}$ in but, tub as ekvnv。

W. w. as in English.

Y. y. as in English。

\section{DIPHTHONGS}

庄. æ. as in Aha, æla.

AU. au. as ou in out, vhauke.

EU. eu. as in vcakateu.

OU. ou. as in cukou.

UE. ue. as in Uewv.

Note. - This alph zbet was adopted by many Interpreters and Chiels of the Nation at the Old Agency in I853, as the Alphabet of the Creek Language. 



\section{MuskokeE AND ENGLISH}

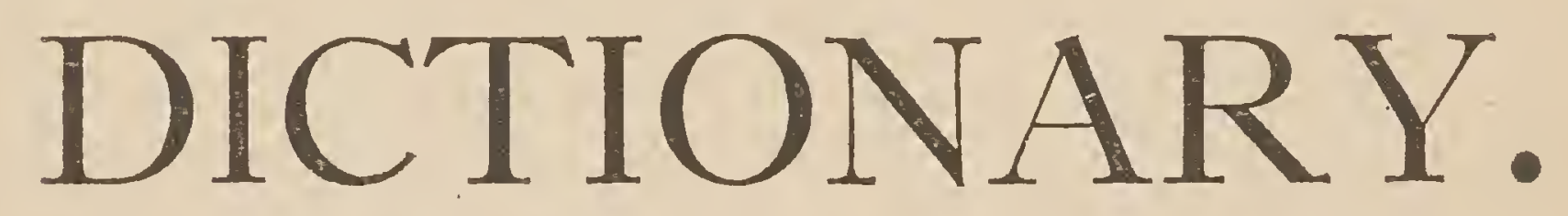

\section{AAK}

A, the first letter in the alphabet, always broad, as a in far.

A, a particle prefixed to a verb means there, that way, from, against.

A-ákhvlátetv, sin., to tow a boat. A-ákhvtapécetv, pl.v.c., to make go down to, or in from a place. A-ákhvtaphóketv, dual., two to come down into from a place. A-ákhvtápketv, s., to come down into, from or to a place.

A-ákhvtapkv'ketv, p., to come down into, from or to a place. A-cacícetv, s., to come down from into a place.

Acácicv'ketv, p., to come down from into a place.

Acákv, a place of landing.

Acáuwetv, p., to take out or pick up.

Acáyetv, s., to land a boat. Acayv'ketv, p., to land a boat. Acéhwósekon, very soon.

Acēkel-hóyetv, d., to backslide. Acēkel-húecetv, s., v. c., to cause to backslide.

\section{$\mathrm{ACE}$}

Acēkel-huecv'ketv, p., to cause to backslide.

Acēkélle, backslidden.

Acēkélletv, s., to go backwards, backslide.

Acēkéllv, a backslider.

Acékel-lv'ketv, p., to go back wards, backslide.

Aceklvfkákvtes, thronged him.

Acēláketv, p., to touch.

Acéletv, s., to touch.

Acēlícetv, v. c., to cause to touch.

Acēlicv'ketv, p., v. c., to cause to touch.

A-cem, towards you or to you.

A-cēmécetv, s., v. c., to make go up or climb.

Acēmecícetv, S., v. c., to cause to $\operatorname{climb}$.

Acēmecicv'ketv, p., v. c., to cause to climb.

Acēmecihócetv, d., v. c., to make climb.

Acémetv, s., to give you.

Acémketv, a ladder, stairs.

Acémketv, s., to climb, ascend go up. 


\section{$\mathrm{ACE}$}

Acēmkv'ketv, p., to climb, to ascend, go up.

A-céyetv, s., to come in from.

A-ceyv'ketv, p., to come in from. A-cúk-ayetv, s., to carry on the back.

Acukóké, on the back.

Acuk-olv'ketv, d., to come in.

Acuk-oyéskv, grievous to be borne, oppressive.

Acukóyetv, grievous.

Acuk-rvnwv, a spider.

Acuk-rv'nwv-rakko, tarantula.

Acukvpéyetv, p., to carry on the back.

A-CV-Cv'k, with me or after me.

Acvcr'k-vtes, followed me, $i, e_{\text {. }}$ came after me.

Acv'fketv, s., to drop from, as rain.

Acv-fv'kv, a sinew.

Acvkáye, according to, following. Acv'k-áyetv, s., to follow after.

Acv'k-cvhécetv, p., to stick in. $A c v^{\prime} k$-fullv'lke, his followers .

Acv'k-hécetv, s., to stick in.

Acv'k-vpéyetv, p., to follow after. Acvmékset, lifting up the head.

Acvppv, an eel.

A-êc-osset, out of, coming out of. Eha! O. Alas!

Alá! O. Alas!

Aem-ossícetv, v.c., to cause to rise.

A-en-kérretv, s., to witness for him.

A-en-kérrv, a witness. His witness。

A-en-kerrv'ketv, p., to testify for him.

Aenkvpv'ken, from.

A-éssetv, s., to take out, pick up, drawn out.

A-essv'ketv, p., to take out, pick up.

\section{AET}

Aètehoyánen, the same.

Aētvkwíketv, s., to cast yourself down.

A-ētvkwikvs, cast yourself down. Afánckákusē, p., very happy, joyful.

Afánc'kusē, s., very happy,joyful. Afanc'kusiyetós, is verv well pleased.

Afek-cak'hetv, s., to watch, to be pricked in heart.

Afekéyetv, s., to shake off.

Afekéyvks, p., imp. mood. Shake off.

Afék-lúmketv, s., to lie on one side.

Afëk-lumkv'ketv, p., to lie on one side.

Afék-rákketv, s., to trust, depend on.

Afék-rákketv, confidence, faith, trust.

Afék-rakkv'-ketv, p., to rest on, to trust.

Afēkv, hair oil, anointing oil.

Aféssetv, s, to strip off the bark of a tree.

Afessv'ketv, p., to strip off the bark of a tree.

$\mathrm{A}^{\prime}$ fetv, s., to mix, thicken, make mush.

Afíhnetv, s., to spring up or out. Afiyáknusē, a little one side, out of the way.

Afryákvnē, out of the way, one side.

A'fkè, mush, hominy, grits.

A'f kè-rákko, large hominy.

A'fkē-senfulótkv, hominy mill, a mill.

Afoklótketv, s., to go around anything.

Afoklotkv'ketv, p., to go around anything. 


\section{$\mathrm{AFO}$}

Afopécetv, s., to go alongside of. Afopēcv'ket.v, p., to go along side of river, etc.

Afópkè, the coast alongside of river or sea.

Afósho, the red elm tree.

Afóswucē, a little bush.

Afóswv, a shrub, bush.

Afulécetv, s., to return, come back.

Afulēcícetv, s., v. c., to make return.

Afulecicv'ketv, p., v.c., to make return.

Afulēcv'ketv, p., to return.

Afulhóketv, d., to return.

Afúlketv, s., to return.

Afúlletv, s., to go near some place, going about.

Afúlloten, being about or around. Afullótet, being around, about.

Afullotécícetv, S., v. c., to fence in, go around:

Afullótē tácetv, to circumcise, cut around.

Afullótetv, s. to turn around.

Afullóthayécetv, s., to fence or drive around.

Afullótkē, around.

Afullótketv, p., to walk or go around.

Afullótketv'ckvn, circumcision, cut around.

Afús-cukcúlkv, loom-gear or harness.

Afushēra, silk, or good thread.

Afúshonv'ke, twine, i.e., twisted thread.

Afús-lepákfv, the waha-tree.

Afúswv, thread.

Afv'cēcícetv, s., v. c., to make glad.

Afvcéckvn, pleasure, gladness.

Afv'ce-cicv'ketv, p., v. c., to make glad.

\section{AFV}

Afv'ckē, s., glad, happy, joyful.

Afvckekó, s., unhappy.

Afv'cketv, joy, happiness.

Afv'cketv, s., to be glad.

Afvckv'ketv, p., to be glad.

Afvckv'lke, p., happy-people.

Afvlécetv, S., to empty in, or pour out.

Afvlecv'ketv, p., to empty in, or pour out.

Afvléknē, s., to one side, out of the way.

Afvlékusē, s., a little one side, out of the way.

Afv'lletv, s., to fling, throw at.

Afvllv'ketv, p., to fing, throw at. A'ha, potato, potatoes.

A'ha-cátē, red potatoes.

Aha-ceréhē, Irish potatoes, i.e., round potatoes.

Aha-iv'kv, potato-vine.

Aha-húte, potato-house.

Aha-hv'po, potato-hill.

Aha-hv'tkē, white potatoes.

Aháhwv, walnut, walnut-wood,

Aháhwv-emvpe, walnut-tree.

A háhwv-en-lókce, walnut fruit.

Ahákē, a picture, an idol, image, similee.

Ahákē-acvkáyē, methodical, according to law.

Ahákeko, : nlike, singular.

Ahákwv, wild geese.

Aha-lánē, yellow potatoes.

Aha-lopv'kcv, an herb, life everlasting.

Al1-áretv, to go near or round.

Aha-rv'fkv, potato-slips.

Ahatvpécetv, s., to come down.

Ahatvpecícetv, s., to bring down, let down.

Aha-tvpecicv'ketv, p., to bring down, let down.

Aha-tvpketv, s., to come down. 


\section{AHA}

Aha-tvpkv'ketv,p.,to come down. Ahauécetv, s., v.c., to make an opening, to open.

Ahauēev'ketv, p., v. c., to open, make an opening.

Aháukē, a door, a hole.

Aháukē-semvtakkákv, door latch. Ahaúkē-svtakkákv, door-latch.

Ahaúkucē, a window, little door. Aháukucē-oh-rv'nkv, windowblind.

Aháukucē-soh-rv'ckv, windowcurtain.

Aha-vcrkè, bunch potatoes.

A'ha-akláukē, wild putatoes.

Aháwv, cirest, box.

Ahayáketv, p., to learn, being taught.

Aháyē, s., green, not ripe.

Aháyetv, s., learn, imitate. To be like.

Aháyv, imitator, mocker, learner. Ahayv'kè, p., green, unripe, untaught.

Ahayv'ketv, p., to be alike, imitate, learn, to teach.

Ahayv'kiyan, p., I have taught. Ahécetv, s., to look this way, after or behind or up.

Ahecicákvte, p., watchmen, keepers, nurses or shepherds.

Ahecicetv, s., to watch, to take care of.

Ahecícv, s., watchman, keeper, nurse, shepherd.

Ahecicv'ketv, p., to watch, take care of.

Ahécka, a prospect, a place to look from.

Ahéckv, lightness.

Ahēcv'ketv, p., to look this way, after, or behind.

Ahētécetv, s., to set fire to.

Ahétskvs, s., lead us not.

\section{AHI}

Ahiyayícetv, s., to shine in.

Ahiyáyvhóketv, d., to shine in.

Ahiyayv'ketv, p., to shine in.

Ahocéfetv, s., to name for or after.

Ahocef kè, named for or after.

Ahócetv, s., to plans, to farm.

Ahóckeko, not planted.

Ahóckucē, the little plants, vegetables.

Ahóckvte, planted.

Ahóckv, a plant.

Ahócv, a planter, a farmer.

Ahocv'ketv, p., to plant, farm.

Ahonécetv, s., to wake from sleep.

Ahonecicáket, p., awaking from sleep.

Ahonéhcet, having slept, being raised from sleep.

Ahonkv'tetv, s., to count, to number.

Ahonkv'tkv, a nuinber.

Ahopánē, corrupt, defiled.

Ahopáneko, harmless, will not spoil.

Ahopánetv, to profane, defile, to spoil.

Ahósketv, s., to leave.

Ahóyetv, d., to go. (Ayetv, s. Vpéyetv, p.)

Ahorkvsákvtes, accompanied.

Ahoyvnécetv, s., v. c., to make pass by.

Ahoyr'netv, s., to come by, pass by.

Ahoyvnhóyetv, d., to come by, to pass by.

Ahoyvnkv'ketv, p., to pass by.

Ahuera, an account standing, a diebt.

Ahúere, a debt.

Ahúeres, is a debtor, is in debt.

Ahúeretv, s., asehóketv, asvpv'kletv, to rise, go in debt. 


\section{AHU}

Ahuerícetv, v.c., to pay a debt, pay any one, forgive.

Ahuericv'ketv, p., to pay a debt, forgive.

Ahuericv, forgiver.

Ahuérv, a debtor, debt.

Abunkv'tetv, s., to count, to cypher.

Ahunkv'tkv, arithmetic, counting. Ahúswv, a rod.

Ahuyíret, rising up.

Ahv'lvtēt-áyetv, s., to lead along. Ahv'lvtêt-svhóyetv, d., to lead along.

Ahv'lvtēt-svpéyetv, p., to lead along.

Ahv'lv'tetv, s., to pull from.

Ahv'lv thícetv, s., to lead many.

Ahv'lvthícv'ketv,p.,to lead many. Ahv'lvtv'ketv, p., to lead, pull fronı.

Ahv'lwv'nv, wild potatoes.

A-hv'tápkvtes, he came down.

Ahv'tvpécetv, s., to come down, bring down.

Ahvtvpēcv'ketv, p., to come down, bring down.

A-hvtrphóketv, d.,to come down. A-hvtvphúecetv, S., V. c., to make come down.

Ahvtvphuecv'ketv, p., v. c., to make come down.

Ahvtrpíketv, s., to come down.

Ahvtv'pketv, s., to come down.

Ahvtvpkv'ketv p., to come down.

Ahwánv, a willow.

Ah'wet, p., having come.

Ah'wetv, p., to come, to have come.

Ah'yit, s., having gone or come. Ak, down in, or down.

Akacéklv'tkē, fallen backwards. Akacéklv'tketv, s., to fall backwards.

\section{AKA}

Akácetv, s., to lessen, break again.

Akacéyetv, p., to lessen, break again.

Ak-áletv, s., to row, as a boat.

Ak-ahkopánetv, s., to play in water.

Ak-ahkopanv'ketv, p., to play in water.

Akáketv, d., Alíketv, s., Avpóketv, p., to rise up.

Akáyetv, s., to go or wade in water.

Ak-caúko, a snipe, a water bird. Akcehóyetv, d., to go into water. Ak-cehoyícetv, $\bar{a} .$, v. c., to make go into water, to dip.

Ak-cetoláskv, the birch tree.

Ak-céyetv, s., to go into water.

Ak-ceyícetv, s., v. c., to dip, plunge, dive.

Ak-cēyicv'ketv, p., v. c., to dip, plunge, dive.

Ak-cvfcícetv, s., v. c., to drop into, as water.

Ak-cvfcicv'ketv, p., v. c., to drop into, as water.

$A k-\mathrm{CV}^{\prime}$ fetv, s., to drop into, as in water.

Ak-cvfv'ketv, p., to drop into, as in water.

Ak-cvkcvhécetv, s., to stick down into.

Ak-cvkcvhecv'ketv, p., to stick down into.

Ak-ēlécetv, S., v. c., to drown anyone, kill in water.

Akēlecv'ketv, p., v. c., to drown anyone, kill in water.

Akēlefletē, p., very steep.

Akēléftē, s., very steep, a bluff.

Akéletv, s., to drown, die in water.

Ak-hatkv, sycamore tree. 


\section{$\mathrm{AKH}$}

Ak-haúkē, a mud hole.

Ak-hopv'nkv, a play, a dance.

Ak-hueretv, s., to stand down in.

Aksehoketv, d.

Ak hviatetv, s., to tow a boat.

Ak-hv'ssē, a lake, a pond.

Ak-hv'ssē-háyetv, artificial pond, a tank.

Ak-hvtápketv, s., to cast down.

Ak-hvtvpecépetv, p., to go down in.

Ak-hvtvpécetv, s., to go down in. Ak-hvtvphoképetv, d., to go down in.

Ak-hvtvpképetv ,s., to go down in. Ak-hvtvpkv'ketv, p.,to go down in. Ak-káyetv: d., to put down in, throw away.

Akkēpúecetv, s., v. c., to make bite.

Akkēpuecv'ketv, p., v. c., to make bite.

A'kketv, s., to bite.

Ak-kófetv, s., to dig out.

Ak-kof hóyetv, d., to dig out.

Ak-kof húecetv, p., to dig out.

Ak-kotórkv, a pond lily.

Ak-kùrkè, dug out, an isthmus.

Ak-kúrkvkē, f., dug out.

Ak-kv'ketv, p., to bite.

Ak-kvtuláswv, the spring frog.

Ak-látketv, s., to fall down in, to

set as the sun.

Ak-látkv, the West, fell down.

Ak-lékhusè, looking warm.

Aklewáhē, muddy, boggy.

Ak-'ewahv'kè, p., muddy, boggy. Ak-licetv, s., to put down in.

Ak-licv'ketv, p., to put down in. Aklopécetv, S., v, c., to bathe, to wash anyone.

Ak-lopecv'ketv, p., v. c., to bathe, to wash anything. A l. -lopv'ketv, p., to bathe, wash.

\section{AKL}

Ak-lópetv, s., to bathe, wash. Ak-topkv, a bath, place of bathing. Ak-lowáhè, boggy, miry.

Ak-máyv, a sun fish.

Aknnv'fketv, s., to strike down in as in water.

Ak-nvf kv'ketv, p., to strike down in.

$A k-n v r k v ' p v$, down in the midst. Ak-nv'thé, steep, steep place. Ak-nvthv'ke, p., steep places. Ak-ócat, things that are in. Ak-ocúknusen, a little while. Ak-omíyetv, s., to swim.

Ak-omiyv'ketv, p., to swim.

Ak-npelófv, swamp, bottom land Ak-ossicetv, s., v. c., to pull out. Ak-ossicv'ketv, p., v. c., to pull out.

Ak-píketv, s., to put into, dip duck.

Ak-píkv'ketv, p., to put into, dip, duck.

Ak-pvsv'tetv, s., to drown, to kill in water.

Ak-pvsv'tketv, p., to drown, to - kill in water.

Ak-réfē, sink hole, a bluff, precipice.

Ak-rékkv, cracklings.

Ak-rolv'kkē, a cave, a sink hole. Ak-sehóketv, d., to stand down in. Ak-sekéyetv, s., to stick down in, gouge.

Ak-sekeyv'ketv, p., to stick down in, gouge.

Ak-súfkē, deep place, sink hole. Ak-sumécetv, S., V. c., to dip immerse, plunge.

Ak-sumēcv'ketv, p., v. c., to dip, immerse, plunge.

Ak-súmhē, a deep hole.

Ak-sumhóketv, d., pass, to be dipped, immersed. 


\section{A KS}

Ak-súmketv, s., to be lost in, immersed, drowned.

Ak-súmkv, a diver, immerser.

Ak-sumkv'ketv, p., to be lost, immersed.

Ak-sumkv'lkē, divers, immersionists.

Ak-sumóhē, muddy, miry.

Ak-svpv'kletv, p., Ak-húeretv, s., Ak-sehóketv, d., to stand down in.

Ak-tasécetv, s., to jump down in. Ak-téhetv, s., to put down in, to duck.

Ak-tépketv, s., to whip in water. Ak-tepkv'ketv, p., to whip in water.

Ak-tópv, a bridge, foot log.

Akúekē, movable.

Akúeketv, s., to move.

Akuekv'ketv, p., to move.

Akúeyètv, s., to move.

Akueyícetv, s., v.c., to remove anything.

Akuevicv'ketv; p., v. c., to remove anything.

Akueyv'ketv, p., to move.

Akv'nvwa, A corner.

Akvpérv, the right side.

Akvsámetv, s., to believe, to praise.

Akvsámv. a believer,

Akvsamv'ketv, p., to believe, to praise, to thank.

Akvsámvs, ready, faithful.

Akvsámvtes, he believed, assented.

Akvskv'nv, the left, left hand.

Akvsv'me, thankful, believing.

Akvsvmēcícetv, s., v. c., make believe, convince.

Akvsvmēcicv'ketv, p., v.c. make believe, convince.

Akvsv'mekat, unbelieving, thankless.

\section{$\mathrm{AKV}$}

Akvsv'meko, unbelief, thankless. Akvsv'mēkokv'lkē, unbelievers.

Akvsvmëpuehócvtet, being persuaded.

Akvsv'metv, s.. to believe, to praise.

Akvsvmhúecetv, s., v. c., to cause to believe, proselyte.

Akvsvmhuecv'ketv, p., v. c., to cause to believe, proselyte. Akvsv'mke, famous, praised.

Akvsv'mkē-tetáyes, abundant praise.

Akvsv'mketv, s., to believe, to praise.

Akvsv'mkusē, little praise.

Akvsv'mkv, faith; beliet.

Akvsv'mkv - óce-eóh - kerkúeckv, confession of faith.

Akvsv'mv, a believer.

Akvsvmv'ketv, p., to believe.

Akvsr'mvrē, the praise.

Akvwv'petv, s., to arise, ascend. Akvwrpíkiye, I am raised up, exalted.

Akvwv'phet, risen up, ascended. Akvwrpketv, S., to rise up, ascend.

Akvwv'pkvketv, p., to rise up, as cend.

Akvwvpv'ketv, p., to arise, rise up.

Akvyv'petv, s., to rise up, arise, Akvyvpv'ketv, p., to rise up, arise.

$\mathrm{Ak}$-wákken, lying down in water.

Ak-wiyetv, s., to fish, to cast into. Akwíyv, a fisherman. Akwiyv'ketv, p., to fish, cast in. Akwiyv'lke, fishermen. Akwvkécetv, s., to lay across, lie in water.

Akwvkecv'ketv, p. to lay across, to lie in water. 


\section{$\mathrm{AKW}$}

Akwvkhokícetv, d., to lay across, to lie in water.

Akyèkletv, s., to grab or grapple down in.

Ak-yeklv'ketv, p., to grab or grapple down in.

Ak-yvkv'petv, p., to walk down in, as water.

Alekv'fetv, s., to pull down from. Alekvfv'ketv, p., to pull down from.

Alepástv, alabaster.

Aletecícetv, s., to make flee this way.

Alétketv, s., to run this way.

Aletkv'ketv, p., to run this way.

Aletv'fetv, s., to pull down from.

Alettvflécetv., S., v. c., to pull down from.

Alètvlecv'ketv, p., to pull down from.

Alētvfv'ketv, p., to pull down from.

Aliketv, s., to sit up, rise up.

Alíkosē, a spot.

Alófetv, s., to daub.

Alóf ket, sticking fast.

Alopótkeko, could not rise or lift up.

Altv, an altar.

Alúmhetv, s., to put to, to sign.

Alumhícetv, S., v. c., to make sign, or put to.

Alv'cè, fastened to, clinging to. Alv'cetv, s., to fasten to, cling to. Alv'skē, weak, easily spoiled. Alv'tketv, s., Ayósketv, d., Apvlv'tketv, p., to fall from.

Amén. Amen.

Anáfketv, s., to strike against. Anaf kv'ketv, p., to strike against. An'esē, anise, (an herb.)

Anv'comè, very little, not much. A-ohcemécetv, s., v. c., to make climb up on.

\section{$\mathrm{AOH}$}

A-ohcemécv'ketv, p., v. c.; to make climb up on.

A. oh-cémketv, s., to climb up on. A-oh-cemkv'ketv, p., to climb up on.

A-oh-kvwápetv, s., to rise up from.

A-oh-kvwapkv'ketv, p., to rise up from.

A-oh-v'tetv, s., to come to from a place.

A-oh-vthóyetv, d., to come to from a place.

A-oh.v'wetv, p., to come to from a place.

A-oh-wáletv, s., to come over from.

A-oh-walvpécetv, p., to come over from.

A-oh-walvpécícetv, S., v. c., to make come over to, throw over. A-oh-walvphóketv, d., to come over from.

A-oh-walvphúecetv, p., to throw over from.

A-oh-walv'pke, having to come over from.

A-oh-walv'pketv, p., to come over from.

A-óssen, part, going out, out of.

A-óssetv, s., Awolketv, d., Asossetv, p., to go out.

A-ossícetv, S., v. c., to drive out, make go out.

A-ossicv'ketv, p., v. c., to drive out, make go out.

A-pefatecícetv, p., to make flee this way.

A-pefathúecetv, s., v. c., to make flee this way.

A-pefátketv, p., to run this way, to flee away.

Apékucē-tvlófv, name of a Creek town on Deep Fork. 


\section{APE}

Apeyátska, p., are you going? Apéyetv, p., to go on a journey. (A'yetv, s., Ahóyetv, d.)

Apíketv, cast into, put up or ir. Apohícetv, s., v. c., to listen, to obey, cause to hear.

Apohicv'ketv, p., to listen, to obey, to be heard.

Apoh-palv'tetv, s., to pour upon us.

Apvkēpáketv, s. to annex, add to. A-pvklíketv, to lap as a dog.

A-pvklikv'ketv, p., to lap as a dog.

Apvlhv'mkē, across, the other side, for.

A-pvlhv'mkvke, p., across, the other side.

A-pvllapícetv, s., v. c., to wrap around.

A-pvllapv'ke, wrapped around.

A-pvllapv'ketv, p., to entwine, to wrap around.

A-pvllapv'kusē, p., entwined, wrapped around.

Apv'lletv, s., to entwine, wrap up or around.

A-pvllv'ketv, s., to entwine, wrap up, lying upon.

A-pvlly'kusè, entwine closely.

A-pvlláye- having it wrapped up. A-priláyetv, s., to wrap around.

Apvlpícetv, v. c., to make roll against, roll against.

Apylpvhóketv, d., to roll about, to flounder.

Apvlpv'ketv, s., to roll about, flounder.

Apvlpvkvketv, p., to roll about, to flounder.

Apvlpv'tkv, a flounder fish.

Apvlv'tetv, (p., Awíketv, s., Akayetv, d.) to throw down or away.

\section{APV}

Apvlvthóyen, the draught, what is thrown away.

Apvlv'tketv, p., Alvtketv, s., Ayorketv, d., to fall or cast. down from.

Apv'skè, parched meal, "cold flour."

Apvtv'kv, pancake.

Apvtv'nv, a bull-frog.

Apvyákv, a chicken snake.

Arahécē, meaning to, or refer. ring to.

Arahkvte, sought after.

Arakkuecetv, s., to celebrate, glorify.

Arakkuecv'ketv, p., to celebrate, gl rify.

Arē, part. from aretv, going about, or being.

Aren, part. from aretv, going about, or being about.

Arepúecetv, s., v. c., to make go up stream.

Arepuecv'ketv, p., v. c., to make go up stream.

Ar'epv, above, i. e., up stream.

Ar'etv. s., Welaketv, d., Fulletv, p., to go about, travel.

$\mathrm{Ar}^{\prime}$ in, s., I going about.

Aríyet, I having gone about.

Arvcúken, where he was.

Arvmrícetv, s., to open the eyes.

Arvpv'tketv, s., to be comforted, of good cheer.

Arvraníyat, I must be going, or be about.

As, to, toward, from, up.

Asáyetv, s., to go to, or around, or from.

Ascéyeiv, p., to come in.

Asehóketv, d., to rise up, stand up.

As-émetv, s., to hand to, to give. As-emv'ketv, p., to hand to, to give. 


\section{ASE}

Asénkv, coast, shore.

Asepusícetv, s., to deliver us.

Askatécv, a little gray bird.

As-káyetv, to catch fish.

As-kayv'ketv, p., to catch fish.

As-kvwv'pketv, s., to rise with.

As-kvwvpkv'ketv, p., to rise with.

Aslícetv, s., to set forth.

As-okóyetv, s., to thrust in by searching.

As-okoyv'ketv, p., to thrust in by searching.

As-óssē, out of, going out.

As-óssetv, s., to bring out, come out.

As-ossícetv, s., v. c., to deliver from confinement.

Asossv'ketv, p., to come out.

Aspáset, being fair, clear, swept.

A-spásetv, s., to sweep, to clear up from North.

Aspasv'ketv, p., to sweep, to clear up.

As-secákvtet, p. part. persecuted.

As-sécet, s. part. being persecuted.

Assécetv, s., to persecute, to run after.

As-séckv, persecution, a race, chase.

As-sécv, a racer, runner, persecutor.

As-secv'ketv, p., to run after, persecute.

As-sēhócetv, s., to be persecuted, run after.

Assēhóketv, d., to stand up, rise up.

Assetv, s., to run after, persecute. Assúnwv, long moss.

Assv'ketv, p., to run after, persecute.

As-ten-kerkúe-cetv, s.,to declare, make known to.

\section{AST}

As-ten-kerkuecv'ketv, p., to declare, make known.

Astv páyetv, s., to put in together, or throw in shares.

Astvpayv'ketv, p., to throw in together.

Asúmketv, s., to go up out of sight.

Asvpv'kletv, p., to stand up, rise up.

Asvpvklícetv, s., v. c., to raise up, make stand up.

As-vtetv, s., to bring from.

As-wíketv, s., to catch fish, to fish.

Atan, from.

Atat, from.

At-áyetv, s., to go down stream. Atē, unless.

Atēh, Atēt, coming from.

Atihóketv, d., to cross the river. Atíketv, s., to cross the river.

Atiyécetv, p., to cross the river. Atohop-kícetv, s., v. c., to fence about.

Atoklomáketv, s., to chew carefully.

Atoklomakhóketv, d., to chew carefully.

Atokorhóketv, p., to flee this way from.

Atokor-húecetv, d., v. c., to make run from.

A-tokórketv, d., to flee this way. Atokorkv'ketv, p., to flee this way.

A-tótetv, s., to send after, this way, send away.

Atótof, when he sends.

Atotv'ketv, p., to send this way, send away.

Atuécetv, s., to go down stream. Atuecv'ketv, p., to go down stream.

$A^{\prime} t v$, comer, down stream, below. 


\section{ATV}

Atv-híketv, s., to mutter.

Atv-hikv'ketv, p., to mutter.

Atvh-lv'tketv, s., to fall down from.

Atvk-háyetv, s., to place in.

Atvkhv'kè, beside, alongside.

Atvk-palv'tetv, p., to cast down from.

Atvk-wiketv, s., to cast down from.

Atvk-yorécetv, p., to fall down from.

Atvk-yúrketv, d., to fall down from.

Atvliyátske-táye-haks? Can you add?

Atvlíyetv, s., to add up accounts. Atvpálv, on this side of the river.

Atv'pha, dog-wood.

Atvsē-Tvlófo, a Creek town near Deep Fork.

A-vcemécetv, s., v. c., to come up from, make come up.

A-vcemëcv'ketv, p., v. c., to come up from, make come up.

A-vcemhóketv, d., to climb or come up from.

A-v cémketv, s., to climb or come up from.

A-vcemkv'ketv, p.s to climb up from.

A-vcrncícetv, s., v. c., to make pour in.

A-vcvncicv'ketv, p., to make pour in.

A-vcv'netv, s., to pour in, or out of.

A-vcrnv'ketv, p., to pour in, or out of.

A-vfopécetv, s., to come alongside stream.

A-vfopēcv'ketv, p., to come along side stream.

\section{AVF}

A-vfullotécetv, p., to come around.

A-vfullothóketv, d., to come around.

A-vfullótketv, s., to come around.

A-vmáketv, p., to give me from or out of.

$\mathrm{A}-\mathrm{v}^{\prime}$ metv, s., to give me from, or out of.

A-vpóketv, p., to rise up.

Av'tetv, s., to advance from, come towards.

A-v thóyetv, d., to advance, come towards.

A-v'wetv, p., to advance, come towards.

A-vwíketv, s., to throw this way from.

Awáretv, s., to cut off.

Awén, coming, or having come.

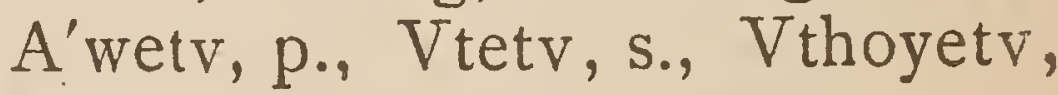
d., to come out from.

Awihéken, next.

Awikáketv, p., to throw this way from.

Awíketv, s., Akáyetv, d., Apvlv'tetv, p., to throw away, from.

Awíyetv, s., to reach out.

Awiyv'ketv, p., to reach out. Awolhúecetv, s., v. c., to bring out.

Awólketv, d., to come out.

A-wvnēn, alone, solitary.

Awv'nvsē, lonely, itself, alone. Aya? Is he going? going?

Ayáyvtē? where I am going?

Ayè, going.

Ayeecéyetv, s., to come in from.

Ayēcícetv, s., v. c., Ayecicv'ketv,

p., make go, send away.

Ayēmahis, I press on, I am going. Ayēmúnkē, perpetual.

Ayépv, the seven year locust. Ayétská? S., are you going? 


\section{AYE}

A'yetv, a way, a passage, road. A'yetv, s., Ahóyetv, d., Vpéyetv, to go forward, to journey.

$\mathrm{A}^{\prime}$ yo, a hawk, falcon.

$A^{\prime}$ yof, when he was going.

Ayókcetv, s., to cling to, to hold fast.

Ayokófetv, s., to wrap up. Ayokófkē, wrapped up. Ayokófkv, a shirt.

Ayo-lv'ste, a black or squirrel hawk.

Ayopécetv, s., v. c., to creep slyly upon.

Ayopecv'ketv, p., to creep slyly upon.

Ayopketv, s., to creep slyly upon. Ayopkv'ketv, p., to creep slyly upon.

Ayopósket, s., answering.

Ayopósketv, s., to answer, to swap or exchange for.

Ayoposkv'ketv, p., to answer, to swap, substitute, exchange.

Ayórketv, d., Látketv, s., Lat$\mathrm{kv}^{\prime} k e t v, \mathrm{p}$., to fall down from. Ayv, a traveler, goer, wanderer. Ayvkhv'mketv, s., to grasp suddenly.

Ayvkhv'mkuse, suddenly, soon, immediately.

Ayvkhv'mkvn, all together, im. mediately, soon.

\section{c. \\ For Che.}

Caháhtv, black locust tree.

Cahcv'kwv, the speckled woodpecker.

Cáhkē, shallow place, a ford, shore, shallow.

Cáhkē-máhē, very shallow.

Cahkē-ohlátkv, waterfalls, shallows.

\section{$\mathrm{CAH}$}

Cáhkēpen, five.

Cahkēpóh-kaken, fifteen, i. e., five upon it.

Cáhkusēe, a little shallow.

Cáhkv, a shallow or ford.

Cáhkv'ki, p., shallows, shallow places.

Cáhkv'kuse, p., a little shallow。

Cáhmelíke, different, unlike.

Ca-hv'rkvslánē, brass kettle.

Cáhwekos, will not take it.

Cáhwèt, part. from Cawetv, p., taking up.

Calátē, after I die.

Cales kúsemvts, I was ashamed, (i.e, a good while ago.)

Cális, though I die.

Cálo, a trout:

Cálof, when I die.

Calv'twè, hard.

Cantákusē, p., very red.

Cántusē, very red, crimson.

Cánv, a house fly.

Cánv-láne, green-headed fly.

Capcv'kē, p., long, tall.

Cápcrkúecetv, p., v. c., to lengthen.

Capcv'kusēe p., a little long.

Cápke, long.

Cápkè, s., long, tall.

Cápko, long.

Capkúecetv, v. c., s., to lengthen, make long.

Cápkusē, little long.

Cárkvs-hv'tke, hardware, pewter.

Cárkvs-lánē, brass kettle, yellow ware.

Cásetv, s., to rake.

Casv'ketv, p. to rake.

Cátē, red. blood.

Catéckv, bleeding, blood letting:

Cáte-elókv, blood sucker.

Cátē-escáukv, lancet, cupping glass. 


\section{CAT}

Cáte-essókcēe, apoplexy.

Cáte-fíhnē, an issue of blood.

Cáten-encáwetv, to bleed, take blood.

Cáte-óme, pink, purple, hay=color.

Cátē-pvlátetv, s., to spill blood, to bleed.

Catē-pvlatv'ketv, p.,to spill blood, bleed.

Catē-tóf ketv, s., to spit blood.

Cate-tof kv'ketv, p., to spit blood.

Cáte! $t$. s., to bleed.

Cathóyetv, d., tu bleed.

Cátusè, a little red, sorrel.

Cátv, bloor.

Cátv-cncáwetv, s., to bleed, to take blood.

Cátv-encawv'ketv, p., to take blood, to bleed.

Cátv-fihnē, blood running, issue of blood.

Cátvfr'kv, a vein, artery.

Cátvkè, s., bloody.

Cátv'ketv, p., to bleed.

Cátv'kusè, p., a little red, reddish.

Cátvkv'kè, p., bloody.

Cawéhpet, p., we having taken them.

Cawepv'ketv, p., to take, to carry.

Cáwetv, p., to take, to carry, receive.

Cawíyvtetáres, I should have received or carried.

Cawv'ketv, p., to take, to carry.

Cáwvyēe, bearing, carrying.

Cé, see! emphatic, as, Hēeres-ce! very good.

$\mathrm{Ce}$, you or thou, same as ceme, cem, cen.

Cefáhlē, mountainous.

Cefahlófvn, in the mountains, hill country.

Céfketv, s., to spur, punch, prick. Céfkv, spur.

\section{CEF}

Céfkv'ketv, p., to prick, spur, punch.

Cefokkícetv, to tap, slap.

Cēhé, your husband.

Cehósetv, s., to remember, de. ceive you.

Cehíwv, your wife.

Cekawvpv'ketv, to bear you up. Cékfé, thick.

Cékfē-hére, dense, very thick.

Cékfetv, s., to be thick.

Cekfícetv, v. c., to thicken, make thick.

Cekficv'ketv, p., v. c., to thicken, make thick.

Cekfv'kē, p., thick, dense.

Cekfv'ketv, p., to get thick, be thick.

Cékhēe, s., raised in a pile, terraced.

Cékhvkē, raised in a pile, piled up.

Cékkottáket, stopping.

Ce-honv'hhvkekós, does not take from you.

Cekósē, lame.

Cekos'setv, s., to limp, to be lame.

Cekossv'ketv, p., to limp, to be lame.

Cektul-cécetv, s., to overthrow, overturn.

Cekúcē, your elbow, $(i, e$, little head )

Cekúlko, a martin.

Cekúnnetv, s., to limp, halt, be lame.

Cekunnv'ketv, p., to $\operatorname{limp}$, halt, to be lame.

Cékv, your head.

Celáyetv, s., to touch, perform, to try.

Celayv'kat, the trial, being tried. Celayv'ketv, p., to touch, perform, to try.

Celékkv, a wren, sparrow. 


\section{CEL}

Celēlehóketv, d., to open the eyes wide.

Cèlêléketv, s., to open the eyes wide.

Celélekv'ketv, p., to open the eyes wide.

Célis, though I die.

Céllè, your foot.

Céllē-léketv, s., to have cramps. Céllé-lekv'ketv,p.,to have cramps.

Celokhóketv, p., to speak another language.

Celokhókv, a tribe, another language.

Celokhokv'lke, p., people of another language.

Celókketv, s., to speak another language.

Celokv'lkē, the Cherokees.

Celúehkv, a wren.

Celúslvmēn, the city, Jerusalem.

Cèm, you or yours.

Cêmé, you or yours.

Cemécetv, p., to climb.

Cémetv, s., to give you.

Cem-hoyv'kvres, d., you shall find, shall be given you.

Cémketv, s., to climb.

Cen', you.

Céna, your body.

Cenákēe, yours.

Céncv, ginger.

Cénkè, your hand.

Cenkucv'lke, sparrows.

Cenkvpákes, forgiven you.

Cén-nákē, yours, kinsman.

Cén-nakv'lkê, your kinsmen.

Centilv'lkē, Gentiles.

Cenvpáken, eight.

Cenvpóhkáken, eighteen.

Cenyúpv, after you.

Cen-yvmahkúeckvn, waste yourself, lasciviousness.

Cepákvkat, among you, with you.

\section{CEP}

Cepánē, s., a boy, little boy.

Cepenkáretv, s., to fear not.

Cepíketv, s., to put in, cast in.

Cepv'nusē, s., a little boy.

Cepvnv'kucè, p., little boys.

Cerá, your back.

Ce-refkáhké-wites, they might kick you.

Ceréhē, s., globular, round, (as pills.)

Cerehv'kē, p., globular, round.

Cerékkvnē, a lump.

Ceréknë, a lump on a tree, a knot.

Ceréncēkè, lumpy, knotty.

Cer'kē, your father.

Cerókco, ground squirrel.

Cesécetv, s., to persecute you.

Ceská, a ground hog.

Céskv, the butt end or root, as of the tree.

Céssē, rat, mouse.

Ces'sē-rákko, a big rat.

Cesto-mécetv, s., you to do with me.

Césv'petv, s., to thrash out wheat, etc.

Cesv'pkē, thrashed out, spilt, scattered out.

Cesvpv'ketv, p, to thrash out, to scatter about.

Ce'sus-Klis't, Jesus Christ, the Savior.

Cetshústē, your daughter, $i$. e., of the father.

Cetshúswv, your daughter, i. e., of the mother.

Cétske, your mother.

Cetskúcē, your aunt.

Cettó, a snake, serpent.

Cettó-estv'kkè, snake bite.

Cetto-háyv, a kind of dance, snake dance.

Cetto.kv'cekv, joint snake. 


\section{CET}

Cetto-lánē, garter snake, green snake.

Cetto-lv'stē, black snake.

Cetto-mékko, rattle snake, i.e., king snake.

Cetto-mekkucē, ground rattle "snake.

Cè turofv, your face.

Cē túrivv, your eye.

Cetv'kkat, the rent, the waste, damage.

Ceıv'kke, torn, rent, worn.

Cetv'kketv, s., to wear out, to tear.

Cetvkkv'ketv, p., to wear out, to tear.

Ce-vpáyetv, s., to receive you.

Ce-wikvkof, when they shall deliver you up.

Ceyácetv, s., you to want, desire.

Ceyacv'ketv, p., you to want, to desire.

Ceyv'lletv, s., to strive hard, to wrestle.

Ceyvllv'ketv, p., to strive hard, to wrestle.

Céyetv, s., Cokolv'ketv, d., Secéyetv, p., to go in.

Ceyícetv, s., to put in, make enter.

Ceyicv'ketv, p., to put in, to make enter.

Ceyiyákē, a quilt.

Cíckv, cause to.

Ciyáyetv, s., to be silent.

Ciyayvhóke, p., silent.

Ciyayvhóketv, p., to be silent.

Ciyayv'kè, s., silent.

Ciyayv'ketv, silence.

Ciyayvketv, p., to be silent.

Coháhto, locust tree.

Cokákusat, sucklings.

Cokcóketv, s., to whine, (as a dog).

Cokcokv'ketv, p., to whine, (as a dog.)

\section{$\mathrm{COK}$}

Cókē, branded, written.

Cóketv, s., to suck.

Cokícetv, v. c., cause to suck.

Cokicv'ketv, v. c., p., to cause to suck.

Cokolv'ketv, d., to go in.

Cókv, a writing.

Cókv-hécv, a pupil.

Cokv'ketv, p., to suck.

Cókv-svholópv, a painter, a printer.

Cókv-tv'lemē, newspaper.

Cókv-tv'lemë-pucásē,post-master, editor.

Cokvtv'leme-sarv,post-rider,mailcarrier.

Colécv, a kill-deer.

Colíhkv, a wren.

Colóswv, muskatine.

Conécketv, s., to move, emigrate. Coneckv'ketv, p. to emigrate, move.

Conéckv, an emigrant.

Coneckv'lkē, p., emigrants.

Cop, Job, the ancient patriarch.

Copécr, a bird named, a killdeer.

Co-póksē, heaped, piled up.

Copoksícetv, s., v. c., to heap up.

Copoksicv'ketv, p., to heap up.

Coposkúecetv, p., v. c., to heap up, make piles.

Coposkúecv'ketv, p., v. c., to heap up, make piles.

Corákko, a horse, i. e., a big deer. Corákko-hóktēe, a mare.

Corákko-hunv'nwv, male horse.

Corákko-húten, stable.

Corákko-ohlíkv, a rider.

Corákko-pínkv, a mule, braying horse.

Corákko-setemárkv, a race horse.

Corákko-wákv, an ass.

Corákkucē, a colt, a pony. 


\section{COR}

Corákkv'lkē, horses.

Coróketv, s., to loose, break loose.

Cóskv, a post oak, post oak.

Cótvnē, the river Jordan.

Cowátucē, a kid or little goat.

Cowátv, a goat.

Cóyetv, s., to write, to copy.

Coyv'ketv, p., to write, to copy.

Cóyvs, s., imper., write, copy, mark.

Cuè, stiff, chilled.

Cuecópetv, p., to be stiff, chil'y. Cuehēe, stiff, (as a dead animal) frozen, chilled.

Cúehétv, s., to be stiff, to be frozen, chilled.

Cuehícetv, s., v. c., to stiffen.

Cúfē, a rabbit, a coney.

Cúfè-éssē, (rabbit's fur) flannel, wool.

Cúfe-essē-vpv'ket, jeans.

Cúfē-túrwv, hawthorn, (red).

Cufo kúnhē, fish-hook.

Cufón-fv'skē, a bayonet or awl.

Cufón-yv'kpē, a fork.

Cvfturwv,red haws,(rabbit's eyes.)

Cufúnwv, an awl.

Cufv'lowv, the edges, the brim.

Cukcórkè, a knot knotted.

Cukcórketv, s., to be knotted.

Cuk-éllè, a post, pillar.

Cuk-éllērákko, a beam, sleeper.

Cúken, in the house.

Cuk-éssē, the beard, whiskers.

Cuk-éssē-es - svkóskv, shaving soap.

Cuk-éssē-svkáskv, a razor.

Cukátv, imprisoned.

Cuk-hv'rpē, the lips.

Cuk-náhetv, s., to rave as a mad man.

Cúko, a house.

Cúko-entálv, rafters, ribs of a house.

\section{CUK}

Cúko-háyv, house-maker, carpenter.

Cúko-hvmēcv'lke, the whole family.

Cukoláhkof, when they had entered in.

Cukoláketv, d., to go in by couples.

Cukolóswucē, a snow bird.

Cúko-ohlícetv-enlíkv, a foundation.

Cúko-ohlv'nkv, the roof of a house.

Cúkopéretv, s., to visit a house.

Cúkopēricv, the guest chamber.

Cukopérv, a visit.

Cuko-rákko, big house, townhouse.

Cuko-semvlíckv, a lock.

Cuko-tempálusat, an alley.

Cuko-tv'lemē, a tavern.

Cuko-tvlemē-háyv,tavern-keeper. Cuko-vfékhonnv'lkē, keepers at home.

Cuko-vpéttv, a piazza.

Cuko-yékcēmáhē, dungeon, inner prison.

Cuko-yékcē-vpíketv, to imprison. Cuko-yékcv-vhecícv, a jailor, keeper of the prison.

Cuko-yékcv, a jail, strong house. Cuko-yúksv, the end of a house, top or cupola.

Cúkpē, a hundred.

Cúkpè-hv'mken, one hundred.

Cúkpēlapēla, a Dutch whipporwill.

Cúkpērákko, a thousand.

Cúkpērákko-vcúle, a million.

Cukpíketa, a chew, as of tobacco.

Cukpíketv, s., to put into the mouth.

Cukpike, put in the mouth.

Cuksákketv, s., to carry in the mouth. 


\section{CUK}

Cuksakkúecetv, s., v.c., to bridle: Cuksákkv, a bridle.

Cuksákkv $\cdot \mathrm{fv}^{\prime} \mathrm{kv}$, bridle, reins.

Cúkucē, a little house, a chamber. Cuk-vtómetv, s., to hoid water in the mouth.

Cúkwv, the mouth.

Cúla, a fox.

Cúlè, a pine tree.

Cules'sv-fv'mpe, snake root.

Cullícetv, s., to strain out, to milk.

Cullicv'ketv, p., to strain out, to milk.

Culókcuwv', tar, rosin, anything sticky.

Culókcuwv'-heléswv, spirits of turpentine.

Culótkv, a cricket.

Cumot'tetv, s., to bounce.

Cumottícetv, s., v.c., to cause to bounce.

Cumotticv'ketv, p., v. c., to cause to bounce.

Cumottv'ketv, p., to bounce.

Cumúkletv, s., to bow the head to the ground.

Cumulcv'ketv, p., to bow the head to the ground.

Cunécketv, s., to move, to emigrate.

Cuneckúecetv, v. c., s., to cause to dwell, to move to.

Cuneckv, a mover, traveler.

Cunékē, stooped, leaning over.

Cunéketv, s., to stoop down.

Cunénē-hótketv, p., to stoop while running.

Cune-nétketv, s., to stoop while running.

Cúntv, a worm, maggot.

Cuntv-fénkv, a glow worm.

Cúntv-heléswv, pink root.

Cupáhlusē, a little peeled, easily peeled.

\section{CUP}

Cupáketv, s., to peel, to strip off. Cupénetv, s.. to pull or prize up by the roots, grub.

Cupénkē, forced or prized up.

Cupvkhóyetv, p.; to peel, to strip off.

Cupvkv'ketv, $\mathrm{d}_{\text {, }}$, to peel, to strip off.

Curáketv, s., to drop off when sticking, as a plaster.

Curakiket, having dropped off.

Curáletv; s., to drop off, break loose.

Cúsē, younger brother when used by a man, and a younger sister when used by a woman.

Cúskelépv, an alder bush.

Cúsketv, s., to strip off blades of corn or limbs of trees.

Cússē, buckskin, leather, upper leather.

Cusse-háyetv, s., to tan leather.

Cússe-háyv, a tanner.

Cusse-lánē, buckskin.

Cússe-sélkv, a string of leather or buckskin.

Custákè, eggs or young ones.

Cusv'lkē, the Jews.

Cutēa, the tribe of Judah or country.

Cutecícetv, v. c., s., to lessen, to make small.

Cútkē, s., little, small.

Cutkucv'lke, sparrows.

Cútkusē, smaller, very small, little.

Cùtkus-máhē, smallest.

Cutúknē, sticking out promi: nently.

Cútvsēe, Judas.

$\mathrm{Cv}, \mathrm{my}$, mine.

$\mathrm{Cv}^{\prime}$, an exclamation of emphasis.

Cv-cérwv, my brother. $i . e$. , of a woman. 


\section{CVC}

$\mathrm{Cv}^{\prime} \mathrm{c}$-hustákē, my sons, children. Crckomē, independent.

$\mathrm{C}$-cusv'lkē, my younger brothers or sisters.

Cvfécetv, s., to strain, to cause, to drop.

Cvfekcákhē, I am jealous, or on the look out.

Cvféknē, well, hearty, lively, health.

Cvféknetv, s., to be well.

Cvféknetv-máhe, very well, active.

Cvféknícetv, s., v. c., to make well, animate.

Cvfencákat, p., that which is well or whole.

Cvfencáketv, p., to be well.

Cvfencícetv, s., v. c., to make well, to cure.

Cvfencv'kè, p., well.

Cvféncrkv'keté? p., are you well?

Cv'fkè, a drop.

Cv'fketv, s., to be dropped as water, to drop.

Cvfunfv'skē, a bayonet.

Cvhácemvts, per. 4th imp. pass, I was very drunk.

Cv'hēe, my husband.

Cvhíwv, my wife.

Cv'hmelíke, species, different qualities.

Crhósetv, s., to excuse, forget.

Cvhvtésē, my daughter-in-law.

Cvkahóyetv, d., to follow.

Cvkáhwèt, following.

Cvk-apéyetv, p., to follow.

Cvk-apéyvres, p., we will follow.

Cvk-áye, according to.

Cvkáyetv, s., to follow after.

Cvkcvhécetv, s., to stick up.

Cvkéksēe, cocked up, cock-eyed.

Cvkencícetv, s., to see-saw.

Crkencicv'ketv, p., to see-saw.

Crkescícetv, p., to hold up one end.

\section{CVK}

Crkesícetv, s., to hold up one end.

Crkfv'cē, a sucker.

Cvkhécetv, s., to stick up.

$\mathrm{Cv}^{\prime} k k e t v$, s., to overtake, to accompany.

Cukófvn, when he has arrived.

Cv-koh'metv, to think that I.

$\mathrm{Cr} \cdot k o$ mè, think of me.

Cv-kotáksē, a bow.

$\mathrm{Cv}^{\prime} \mathrm{kv}$, my head.

Cv'kylá, woodpecker, white and black.

Cv'la, a roller.

Cvlápetv, s., to mix, to knead.

Cv-láwetv, s., to be hungry.

Cvlawóset s., I being hungry.

Cvlécetv, s., to roll, (as a wheel, etc.)

Cvléckv-vtóhkv, a teamster.

Cv-lekón, ere I die.

Cvlhoyíetv, p., to make roll.

$\mathrm{Cv}^{\prime}$ lle, my foot.

Cvlle-echóswucē, my little toe.

Cvlle-etske, my great toe.

Cvlv'kme, wet, marshy, compressed.

Cv-lvránet, I about dying.

Cvlv'twe, hard.

Cvlr'we, hungry.

Crméksè, cocked up, as the head or tail.

Crméksetv, s., to cock up the head or tail.

Crmeksícetv, s., v. c., to cause to cock up head, etc.

Cvmeksícrkétv, p., v. c., to cock up.

Crmóttetv, to bound.

Crmp-cákv, a bell.

Cvmp-cákv-fv'kv, a bell rope.

Cvmp-cóyetv, s., to trot.

Cv'mpē, sweet.

Crm'petv, s., to be sweet. 


\section{CVM}

Cvm'pétskis, "though you are sweet."

Cv'ná, my body.

Cvnákē, mine.

Cvnásetv, se to twist one's self round, to dodge.

Crnasv'ketv, p., to dodge, twist round.

Cv'nkē, my hand.

Cv'nkē-nv'rkvp-húera, my middle finger.

Cvnkēsmélkv, my forefinger, $i$. e., to point with.

Cv'nk-étskē, my thumb.

Cvnokíket, I being sick.

Cvnv'ksat, a ridge.

Cvnv'ksē, sidewise, also a ridge.

Cvnv'ksetv, s., to turn sidewise.

Cv'nvnvcáketv, s., to be a wall.

Crnvnv'kē, a long ridge or wall.

Cvpénetv, s., to grub.

Cvpiyécetv, s., to plow.

Cvpiyéckv, a plough.

Crpíyecv, a plower, a ploughman.

Crpiyecr'ketv, p., to plow.

Crpiyetv, s., to hoe.

Crpiyv'ketv, p., to hoe.

Cvpófucē, a little field, a garden.

Cvpófv, a field.

Cvpófv-atótkv, a farmer.

Cvpórekot, not satisfied.

Cvpóret, being satisfied.

Cvpóretá, it is enough.

Crpóretv, s., to have enough.

Cvppúcē, my son.

Crpucá my grandfather.

Crvpucásē, my master.

Cvpúecetv, s., be respectful, humble.

Cvpr'k-hóketv, pass. p., to be angry.

Cvpv'k-hokícetv, p., to make angry.

Cvpv'kkē, angry, mad.

\section{CVP}

Cvpv'kke-ómē, sullen, gloomy.

Cvprkketv, s., to be angry.

Cvpv'kketv, rage, anger, wrath.

Cvpv'kketv-máhe, very angry.

Cvprkkíket, being angry.

Cvprkkúecetv, v. c., to make angry.

Cvrá, my back.

Cvráhv, my elder brother, when spoken by a man; elder sister, by a woman.

Cv'rkēe, my father.

Cvrótetv, s., to cripple, to dislocate.

Cvrótkē, crippled, dislocated.

Cvsahlécetv, s., V. c., to rattle leaves.

Cvsahlecv'ketv, p., v.c., to rattle, (as leaves).

Cvsáhletv,s., to rattle, (as leaves) etc.

Cvsáhlv'ketv, p., to rattle, (as leaves).

Cvsē, a pumkin.

Cvshvpéskē, fodder.

Cvsketá, a mark to shoot at.

Cvsketv, s., to chop, cut, to peck.

Cvsteméres, I am poor, will suffer.

Cvstemeráres, I will suffer, will be poor.

Cvstómvr-haks? what will become of me?

Cvstvlē, a watermelon.

Cvsvránet, about taking me.

Cvsv'rhaks? Will he take me?

Cvsvrákketv, s., to rattle.

Cvsvrákkúecetv, s., v. c., to cause

to rattle, shake.

Cvsvsákkv-rákko, wild indigo.

Cvtákketv, s., to bounce back.

Crtetáckv, the lower part of the back.

Cv'to, iron, stone, a rock.

Cv'to-cáskv, a stone mason. 


\section{CVT}

$\mathrm{Cv}^{\prime}$ to-casv'kwv, pebbles, gravel. Cv'tocè, a stone, a little rock.

Cv'to-enkórkv, stone quarry, or iron mine.

$\mathrm{Cv}^{\prime}$ to-esfaséckv, a whetstone.

Cv'to-eskapélkv, a crow-bar.

Cv'to-fulótkv, a grindstone.

Cvto-fv'skē, an iron wedge, sharp iron.

Cvto-háketv, s., to petrify.

Cvto-kórkv, stone coal.

Cvto-kunawv, money, stone beads.

Cvto-kunv'p-hv'tke, silver money. Cvto-kunvp'lánē, gold, gold coin. Cvto-pácv, a blacksmith.

Cvtopv'rv, behind me.

Crto-prtihócvtē, the stone pavement.

Cv to-tetv'kkákv, a chain.

Cvto-tótkv, steel.

Crto-tótkv-hutē, a stove.

Cvto-tvlópē, soap stone.

Cv'tskē, my mother.

Cvwíyetv, s., to betray me.

Cvwv'nwv, my sister.

Cryayícetv, s., to be easy, quiet. Cvyíyakè, easy, quiet, dumb.

\section{E.}

E, En, Em, Him, himself, themselves.

Eakv'lkv, disease.

Ea-hoporénvkv, self-knowledge.

Ec or Ecē, you, yourself.

Ecahóyen, murmuring.

Ecayáketv, s., to murmur.

Ecè, you, yourself.

Ecē-culákvkis, p., though you are old.

Ecēcv'k-ayáres, I will follow you. Ece-fv'ckvkekvs, all hail! happiness to you!

Ece-fvstepúecen, give charge to attend you.

\section{$\mathrm{ECE}$}

Ecē-húeretv, s., to owe me.

Ecēkvsámetv, s., to praise, thank you.

Ecen-okécvken, loving you.

Ecen-rv'petv, s., to resist you, to meet.

Ecē-páket; part., being with you. Ece-páketv, s., to be with you. Ece-pakvkáres, I will be with yo". Ecēpíkat, within you, in you.

Ecē-pv'kepéyvres, p., we will be with you.

Ecē-pv'ketetáken, will be among you.

Ecérwv, her brother.

Ecè sécetv, s., to persecute you. Ecē-sehéckē-nómat, if he shall persecute you.

Ecē-sehocv'ke-nomat, p., if they shall persecute you.

Ecéskv, the root.

Ecē-tótetv, s., to send you forth. Ėce-tótvkis, I send you forth. Ecē-wolícv, your neighbor. Ecéyats, not go in. Eceyetv, s., to go or enter in. Ecēyícetv, v. c., to make go in. Echás-hv'rpe, beaver-skins. Echás-líke, beaver dam.

Echáswv, a beaver.

Echóskelépv, alder.

E-chúseko, barren, sterile.

E-chustákè, p., eggs, young ones, also her sons or her daughters.

E-chústē, s., his daughter.

E-chustv'lkè, his daughters.

E-chúswv, an egg, seed, young one.

E-chúswv, also her daughter or son.

E'cká, a louse.

Ec'ka-espókv, comb, (fine).

Eckópetv, to roast.

Eckucé, a small or young louse. 


\section{ECK}

Eckvpúswucē, a gnat.

$\mathrm{E}^{\prime} \mathrm{co}$, a deer.

Eco-cé, fawn, young deer.

Eco-em-pvkánv, crab-apple,(deer peach).

Eco-étskē, a doe, hind.

Ecófv, in you.

Ecóh, upon yourself.

Eco-héceko, (an herb) golden rod.

Ecóh-pvtákeh, within you.

Eco-hunv'nwv, male deer, buck.

Eco-hv'rpē, deer skin.

Eco-pílkv, an elk.

Ecopunáyécetv, s., to reproach.

Ecósset, coming out.

Eco-vpéswv, venison.

Ecuk-lékwv, his sore mouth.

Ecúku-yakúecetv, v. c., s., to pack on the back.

Ecuku-yícetv, p., v. c., to pack on back.

E-cúkwv, his mouth.

Ecúsē, his younger brother, her younger sister.

Ecvkotáksē, an archer, bowman.

E-ēlécetv, s., to kill himself.

E élawécetv, to fast.

E-énkvpiyecícetv, s., to turn away from him.

E-ètem-fv'tcetv, s., to agree among ourselves.

Ef, Eve, (name of first woman.) Efékē, his heart.

Efékē-mvráhkv-háketv, converse.

Efékē-nókkēe, sorrowful, painful.

Efékē-nókketv, sorrow, pain.

Efékē-nokkícetv, v. c., s., to give pain.

Efékē-nokkicv'ketv, p., v. c., to give pain.

Efékē-tásketv, palpitation of heart.

Efék-híyē, heart-burn.

\section{EFE}

Efeknóketv, heart-sickness.

Efépē, a gourd.

Ef kv'nco, a tick.

.Ef kvncocé, seed tick.

Efúcē, a young dog, a pup.

Efúlowv, the withers of a horse.

$\mathrm{E}^{\prime} \mathrm{fv}$, a dog.

Efv'tcécē, chaste, pure, right.

Efv'tcecv'kè, chaste, pure, right.

Ehákē, delay, patient.

Eháketv, s., to be patient, to wait, disfigure.

Ehánetv, s.; to scold, find fault.

Ehánhúecetv, s., to scold, abuse.

Ehánh-yúeyetv, s., to be scolded.

Ehánv'ketv, p., to scold, find fault.

Ehapérkē, vain, base.

Ehapérketá, infirmities, vain things.

Ehapérkúecetv, s., to condemn as vain.

Ehapérkuecv'ketv, p., to condemn as vain.

Ehapérkv, vanity, in vain.

Ehawéckv-eyácetv, ambition.

Ehē, her husband, a husband.

Eheckúecetv, s., to appear, to be born.

Eheckuecv'ketv, p., to appear, to be born.

Ehelakséceko, cannot deny or contradict.

Ehelaksécetv, s., to deny, contradict.

Ehénwv, truth.

Ehe'reko, not good.

Éhetv, s., to hide.

Ehitákē, their wives.

Ehiwvránetv, going to marry.

Ehkákēs, to secrete.

Eh'kē, secret.

Ehken, a secret place.

Eh'ketv, s., to hide. 


\section{EHK}

Eh'kusē, secretly, privately.

Ein'leko, evergreen.

Eh'lekos, cannot die.

Eh'meko:, will not give.

Ehóhsekos, not lost.

Ehólē, November, frost month.

Ehómvn before him.

Ehopáhkátskvs, ye shall be with.

Ehopáketv, to be with, accompany.

Ehosáket, being lost, forgotten.

Ehoséketv, s., to lose, forget.

Ehósetv, s., to forget.

Ehosícv, a deceiver.

Ehóskv, loss, damage, error.

Ehosvkúecetv, v. c., to deceive.

Ehótkē, dangerous.

Eh'set, having taken.

Eh'setv, s., to take.

Ehúte, his house.

Ehútē-tákē, their house.

Ehv'lewv, a wallet, "scrip."

Ehv'rpē, his skin, the hull, pod, shell.

Ehv'rpe-opvnv'pv, a rose.

Ekísè, his hair.

Ekkócat, smoking.

Ekkócē, smoke.

Ekkócē-hutē, stove-pipe.

Ekkócetv, s., to smoke.

Ekkocv'ketv, p., to smoke.

Ekkocv'lket, it is smoky.

Ekófe, his flank.

Ekofkv, his flap.

Eks, sign of negative at the end of words, as hereks.

$\mathrm{Ekv}$, his head the head.

Ekvcē, the elbow, little head.

Ekvcē-tóhtekékv, the elbow joint.

Ekv-éssè, the hair of the head.

Ekv-féketv, head pay, pole tax, tribute.

Ekv-fúne, the skull bone.

Ekv-homésse, foretop, or forelocks.

\section{$\mathrm{EKV}$}

Ekv-hómv, the forehead.

Ekv-kvtécetv, self-examination.

Ekv'lpe, the brain.

Ekv'ncátē, red ground, red earth.

Ekvncvpúecetv, s., to humble one's self.

Ekvncvpúecvsíyetos, I humbled myself.

Ekvn-éfv, a ground puppy, ground lizzard.

Ekvn-haúkē, a cave, hole in the ground.

Ekvnhvlháwat, a hill.

Ekvnhvlháwv, p., mountains.

Ekvnhv'lwē, s., a mountain, a hill.

Ekvnhv'lwucē, a hillock, mound.

Ekvnkórkē, a "dug out," grave, ditch.

Ekvn-nekéyet, earthquake, earthshaking.

Ekv-nókke, headache.

Ekvn-svhopákv, a map.

Ekvn-tácv, a surveyor.

Ekvntv'ckè, surveyed land.

Ekvn-tv'ckv, the land surveyed.

Ekvn-tvpéksē, flat land, plane.

Ekv'nv, the earth, land, ground.

Ekvpv'kē, separated.

Ekvsahmátskvs, p.,don't ye glory. Ekvsámetv, s., to glory, boast.

Ekv-sen-hvlátkv, a head stall of bridle.

Ekvsv'mē, proud, ambitious.

Ekvsv'metv, pride, hautiness.

Ekvsv'metv, s., to glory, boast, be proud.

Ekv-sv'mē-yvkv'petv, s., to strut. Ekvsv'mkv, pride, hautiness.

Ekvtóskv, dandruff.

Ekv-tvháknē, light headed.

Ekv-tvháknusē, a little light headed.

Ekv-wv'nv'pv, the crown of the head, pate. 


\section{$\mathrm{EKV}$}

Ekv-yékcē, hard-headed.

Elaúketv, s., to starve, to perish for want of food.

Elaúko, famine, a fast.

Elauwáketv, p., to be an hungered, fast, starve.

Elaúwè, hungry, famishing.

Elauwécetv, v. c., to fast, to starve one's self.

Elauwetv, s., to fast, be hungry.

Elè, dead, fainted.

Elécetv, s., v。 c., to kill, cause to die.

Eléckv, death.

Elécv, a butcher, a murderer.

Elecv'ketv, p., v. c., to kill, cause to die.

Elehcétskvs,(8th commandment) Thou shalt not kill.

Elehócvránen, about to be killed, sacrificed.

Elépetv, s., to die.

Eléps, he is dead.

Elesecícetv, S., to grieve, to provoke.

Eléskat, being sad, gloomy, vexed.

Eléskē, gloomy, sad, vexed.

Eléske-ómē, morose, soured.

Elésketá, chagrin, vexation.

Elésketv, s.,to vex, grieve, be sad.

Eléskv, a gloomy person.

Eleskv'ketv, p., to vex, grieve.

Eletáyet, perishable, mortal.

Életv, s., to die, (Pvsátetv, p., to die,) expire.

El'kv, death.

Elláksv, the hoof, his hoof.

Elle, the foot, feet.

Ellē-awíketv, s., to step.

Ellēcéskv, the heel.

Ellécetv, s., to be under.

Ellécetv-awíketv, to cast under.

Elle-cúkpē, a centipede.
ELL

Ellécusan, a little underneath.

Ellécusē, a little underneath.

Ellécv, underneath, beneath.

Ellécv-máhe, the lowest, lowermost.

Ellē-enhátkv, a stone bruise.

Ellè-étskē, the big toe.

Elle-hómv, the fore foot of an animal.

Ellē-hómv-svkásetv, s., to paw.

Ellē-hv'pon, foot-print, a rut, track of a wheel.

Elle-kosó-sówv, toe nail, a claw.

Eilen-páko, the calf of the leg.

Ellen-tápketv, s., to stumble.

Ellēn-táppetv, s., to tumble, stumble.

Ellēn-tappúecetv, to cause to stumble.

Ellēn-tétv, s., to trace back, to quote.

Ellè-ocá, a pot, an oven.

Elle-ófv, sole of the foot.

Elle-ostv'kusat, fourfooted.

Elle-séwvnákv, hobbles.

Elle-súlkv, a worm, hundred legs.

Elle-tóhtohkáye, cross legged.

Elle-toktúswv, the ankle.

Elle--wesákucê, the little toe.

Ellē-wesákv, a toe, claw, nail, talon.

Elle-yunákta, hollow of the foot.

Elle-yúpv, the hind foot.

Elofv'hkvn, when he dies.

Elúpē, his liver.

Elv'cē, its branch, or limb of a tree.

Elv'ffetv, s., to cut one's self.

Elv'ksv, his hoof.

Elv'nna, he who had died.

Elvpápv, a ring worm.

Em, En, E, he, she, or it, himself.

Em-acánetv, s., to encourage, push on. 


\section{EMA}

Em-acúks, blaming.

Em-aherícetv, s., to fix him, help him.

Emáhlvpátv, a comforter.

Emáhlvpv'tecícv, the Comforter.

Emáhlvpv'tketv, s., to comfort, consolation.

Emáhlvpv'tkvrë-tayekátes, would not be comforted.

Emáhopánekon, without cause.

Emáhlvpv'tetv, s., to comfort, be discreet.

Emáhlvpv'tkē, comforted, discreet.

Emaketv, Emetv, to give him.

Em-akvsvmetv, s., to promise, approve him.

Em-akvsv'mhóyetv, d., to promise each other.

Em-alóstícetv, s., to charm.

Em-aráhketv, s., to be transfigured, converted.

Emáres, I will give him.

E'mat, giving.

E-máyetos, I do give him.

Eme. Em. E., he, she, or it, him. Em-êfékhúnetv, s., to rest, reside.

Emēhakákat, they waiting.

Emè-háketv, s., to wait for.

Emē-hákē-wáketv,s.,to lie in wait.

Emē-heckúecetv, s., to approach, show himself.

Emē-heckúecv'ken, a revelation.

Em-éhetv, s., to hide from him.

Em-ehíkekos, it will not be hid from him.

Em-ekátes, it is not given him.

Emēkusápē, religious.

Emekusápetv, s.,to pray for them.

Emèkusapv, a praying person.

Em-ékvsámetv, s., to banter, defy.

Emēlíce-húerē, an apprentice.

Emén, amen, truly, so be it.

Em-enhéret, being fond of.

\section{EME}

Em-enhéretv, s., to be fond of, to like.

Em-enhērēmáhe-sekó-tetás,doubt it very much.

Em-enhónretv, s., to depend on. Em-enhónretv-seko, distrust, to dislike.

Emēófv, in him.

E-mérretv, s., to pity, forgive.

E mérretv-enkvpv'ketv, forgiveness.

E-merríyet, having pitied.

E-merrúsetv, s., to be very merciful.

E-merrusv'kē, piteous, merciful.

Em-esē, a leader, a governor.

E-méskè, perspiration, sweat.

E-met, he, himself, it is he, also émet, a gift.

Emè-tawvt, among themselves.

Eméte-hósetv, s., to imagine.

Eme-tektv'nket, privileges.

Eme-tetákekot, unfit, it won't do. Emē-tetákvs, suitable, perfect, it will do.

Eme-tetayécet, equalling.

Emē-tetayécetv, s., to equal.

Em-étte, its fruit.

Em-ettē-sekót, fruitless.

E'metv, s., to give, (p., Emáketv). E'metv, a gift.

Eme-tvlhv'mkē, native.

Eme-wíketv, s., to avow, submit. Eme-wíkit, I commit myself to him.

Eme-yúksv, his end, its end.

Eme-yúksv-sekó, everlasting, without end.

Em-fiyátv, guide, helmsman.

Em-fiyv'tetv, s., to guide.

Em-fulótkv, meal.

Emfulótv, a miller.

Em-fv'skv, its edge, the edge, the blade. 


\section{EMF}

Emfvtcéckv, a judge.

Emfv'tcetv, a mediator, mediation, propitiation.

Em-hóyetv, d., to give, receive, to find.

Em-hoyv'ketv, p., to give, to receive, find.

E'mkv, a gift.

Em-máhē, the father-in-law.

Emmányuēl, Immanuel.

Emmáyetv, s., to fan.

Em-mékko-em-eyáskē, loyal.

Em-merrúsetv, s., to be merciful.

Em-méskē, his sweat, perspiration.

Em-mésketv, s., to sweat, perspire.

Em-meskúecetv, s., v. c., to make sweat.

Em-móke, the down of birds.

Em-mvháyetv, so, to teach, instruct, advise.

Em-mvháyv, his teacher, teacher.

Em-mvnvttēpē, safe.

Em-mv'ttē, s., his fault, sin, error. Em-mvttv'ke, p., their faults, errors, sins.

Em-oh-onáyit, I talking to them. Em-ohyúpv, after him.

Em ohyúpvsan, a little after him. Em-okháckv, his fun.

Em-onáyetv, s., to tell him, testify to him.

Em-óreks, lacking.

Empáletv, s., to lend, to give.

Empénkv'lketv, s., to be afraid.

Empóhetv, s., to hear him, her or them.

Empókvpē, the mast of a ship.

Em-polókcv, the hip.

Em-punáyvkè-ónkat, independent.

Em-porhóyetv, s., to bewitch.

Em-póyetv, s., to win.

\section{EMP}

Em-punáyv, a speaker.

Em-pv'kpvkē, a flower, its flower. Em-pv'lesépetv, s., to be revengeful.

Em-pv'lse-sekó, no relations.

Em pvlsv'lkē, his relations.

En-pvtícetv, a line.

Emúnken, always, ever, yet the same, until.

Emúnkes, it is always so or the same.

Emúnkest, it is always the same.

Emúnkv, always, yet.

E'muntáletv, s., to conquer, defeat, prevail.

E'muntálit, I overcoming.

Emuntalv'ketv, p., to overcome, prevail against.

E'múntvle, at last overcome, surpassing, exceed.

Em-vkérrē, subtlety, cunning, craft.

Em-vcáhnetv, s., to exhort them. Em-vkérres, he is cunning, sly, deceiving.

Em-vkérretv, s., to be cunning, sly, deceiving.

Em-vkerríckvhen, v. c., prudent. Em-vkerríckvt-vnv'comé, national.

Em-vkórv, sap.

Em-vlósetv, s., to intend.

E-mvnettícē, boyish.

Em-vnícetv. s., to help.

Em-vnícv, his helper.

Em-vnvttépē, safe.

Em-vnv'ttetv. s., to escape, be safe.

Em-v'pè, his handle, stem, stalk. Em-vráhkè, queer, strange, changed.

Em-vráhketv, s., to be changed, converted.

Em-vrapv'tetv, S., to console, encourage, cheer. 


\section{EMV}

Em-vséhetv, s., to rebuke them. Em-vtéken, a hem. Em-vyakhv'mkē, passionate. Em-wíketv-hàyetv, to select. Em-wíketv, s., to leave off. Em-wíketv, a trustee, command. Em-wíyetv, s., to offer, to present.

En'a, the body, his body. Ena-élēe, a corpse, dead body.

Ena-ceréhè, the muscle.

Ena-éssè, the hair of the body.

Ena-hv'mkē, kinsman.

Ena-hvmkv'lkē, kinsmen.

Enakē, his, hers, or its.

Enáke-ehkáket, mysterious.

Enáke-háyetv, s., to own or claim anything.

Enáke-árat, rich, having much.

Enákē-táres, it will be his.

Enáketókes, it is not his.

Enáketon, it is his own.

Enakúecetv, s., to possess, to take, attain, receive.

Enakúeckv, possessions.

Enalv'tcē, a limb or member of the body.

Ena-nóketv, s., to be diseased in the body.

Ena-nókke pain, sickness of the body.

Ena-ófv, within the body.

Ena-tórpè, a joint of the body.

Ena-tvhokícetv, s., to hedge.

Ena-tvlécē, s., his body stripped. Ena-tvlécetv, S., v. c., to strip it naked.

Ena-tvlecv'ketv, p., to strip themselves naked.

Ena-tv'lkè, s., the body only, naked.

Ena-tv'lkusē, rather naked.

Ena-tv'lkvkē, p., naked.

Encáhketv, to grudge.

\section{ENC}

En-cáhwet, having taken from him.

En-cákēe, partial, cautious, liberal. Encáketv, S., to beware of, liberal.

En-cákusat, having been partial.

En-cakv'spv, a lizzard.

En-cákvtes, withheld, denied them.

En-cáwepvks, receive it from him.

En-cekcéketv, s., to tickle.

En-cekótetv, s., to plug.

En-cektulcécetv, to overset, overturn.

En-colécetv, s., to strain out, to strain, (as milk).

En-colópetv, s., to print.

En-cukó-vtehkv'lkē, the household, families, those in the house.

En-cútkuset, the least.

En-cvliáhtv, a cock's spur.

En-cv'sketv, s., to cut or trim off, a chip.

En-cvtokúnawē, moneyed.

En-cvtokunv'p-hútē, a purse, money house.

En-cvtokunv'p-hútē - esekvsámē, purse proud.

En-crtokunv'p-sekó, moneyless.

E-nck-rícetv, s., to burn one's self.

Enérkv, seed, its seed.

En-fihne, the channel.

En-fiyátv, a cistern, water pit, pilot.

En $-\mathrm{fv}^{\prime} \mathrm{cv}$, his collar bone.

En-fvitcécetv, s., to advocate.

En-fv'tcvn, opposite, against.

En-fvtcv'petv, S., to deliver, release.

Enhákē, sound, voice, its sound.

Enhauhícetv, s., to open.

En-háyvkot, would not make her. 


\section{ENH}

Enhéckē, should obtain, is worthy. Enhéckekó-táye, not in danger.

Enhécke-tetáyetv, S., to be in danger.

Enhérketv, s., to bring forth.

Enheckúecetv, 's., v. c., beget, bring forth.

Enheckuehócetv, d., v. c., beget, bring forth.

En-heckv, his appearance.

Enheckvranaten, inheritance.

Enhéfkv, vapor.

En-herákes, p., blessed, is good.

En-héres, s., blessed, nappy.

En-héssē, friend, his friend.

Enhócv, flowers, prints.

En-hófketv, s., to stretch.

En-hohíketv, to inquire of them, to call the.n.

En-homáhte, prior, previous.

En-homáhtē-máhat, principal.

En-homáhtv, patriarch, pilot.

En-homécetv, s., to hate, contemn.

En-homéckē, hateful, loathsome.

En-homéckv: hatred, odium, abomination.

En-hómpetv, his food.

En-homáhtv, patriarch, leader.

En-hómv, before him.

En-homvhótat, the chief.

Enhónretv, s., to be lazy, to depend on.

Enhónretv, to trust.

En-hónrē, lazy, trusty.

Enhónrkv, grace, favor, trust, hope.

Enhónrvkè, grace, faithful.

En-hópokē, select, choice, elect.

En-hopóketv, s., to elect, select, choose.

Enhoporénkv-hvte, wise.

Enhopóyetv, s., to choose.

En-hopoyv'kvte, elected, chosen.

\section{ENH}

En-hoyvnecicetv, s., v. c.; to make it pass.

En-hoyvnetv, s., to pass it.

En-húehketv, s., to call, invite.

En-húeketv-tetáyvtes,might have called.

En-húeretv, state.

En-húeretv-rakké, an office.

En-huerícetv, v. c., to cock a gun.

Enhúerv, a pledge, oath.

En-húnnv, a skirt.

Enhúnretv, his hope.

En-hv'mkusē, alone, solitary.

En-hvtecéskē, first, original.

En-hvtecéskv, the first, beginning.

Enká, yes.

En'kē, the hand, his hand.

Enke-kvskv'nv, left-handed.

Enke-offv, the palm of the hand.

Enkerkúecetv, s., to fulfill, show forth.

En-kérv, s., his disciple or learner.

En-kerv'lkē, his learned ones, learners.

Enkès-mélkv, the fore-finger, i. e., to point with.

Enkē-sósowv, finger nail.

Enke-taklóswv, the wrist.

Enke-tórpē, the knuckle.

En-kétse-célketv, s., to tickle.

Enk-étskē, the thumb, the mother of the hand.

Enke-tvpéksē, the palm of the hand.

Enke-tvpv'rv, back of the hand.

Enkē-wesákv, the finger.

Enkē-wesákv-téhkv, a finger ring.

Enkē-wesákv-tohtékekv, joints of the finger.

Enkē-wesákv-tvhóknē, light-fingered.

Enke-yúksv, end of the finger.

Enk-hv'tv, just now. 


\section{ENK}

En-komekátes, he did not want it for him.

En-kóretv, s., to chisel, dig out.

Enkórkv, a mine.

Enk-semfulótkv, the cuff, wristband.

Enkúnhetv, s., to trap, take in a trap.

Enkusápetv, s., to beg, pray for, to lack.

Enkusv'pkē,poor,lacking,in want. Enkusv'pketvn, to be poor, in want.

En-kvcéyēs, should they break it. En-kvfétv, s., to milk her.

En-kv'netv, s., to bait, to trap, lie in wait.

En-kvpáhkv-kos, I shall not part from him.

En-kvpáketv, s., to separate from him.

Enk-vpérv, the right hand.

En-kvpiyecícetv, v. c., to expel, cause to depart.

En-kvpv'kē, absent, left.

En.kvpv'ken, from, separate.

En-kvpv'ketv, s., to depart, separate from him.

En-kvskv'nv, the left hand.

En-kvsv'mketv, s., to be weary.

En-kvsvmkv'ketv, p., to be weary.

En-kvtv'rpv, the pit of the stomach.

En-lákhē, barb, notch.

En-letáfetv, s., to lay down the fence for him.

En-létketv, s., to flee from him.

En-líketv, abiding, residing.

En-líketv-máhe, permanent.

En-lókcē, its fruit.

En-lopícē, benevolent, kind.

En-lopícetv, s., to do good, to be kind, glad.

\section{ENL}

En $l^{\prime}$ pè, soon.

Enlv'pe-stomómosen? how soon?

Enlv'pkē, quick, soon.

En-nénnē, its path, trail.

En-nénnē-háyetv, s., to make a path, a furrow.

En-nénnē-hēcetv, s., to hope, to see the way.

En-nvrkv'pv, its half, half of anything.

En-nvrkv'pv - rén - nvrkv'pv, a quarter, $i$. e., half of half.

E-nócetv, a cravat, necklace.

E-nóckv, handkerchief, cape.

E nóckv-rákko, a shawl.

$\mathrm{E}$ nókkē, sick, in pain.

E-nókkē-máhe, very sick.

Enókketv, sickness.

Enókketv, s., to be sick.

Enókketv-yékcē, cholera.

Enokkícetv, V. c., s., to afflict, gripe, hurt.

Enókwv, his neck.

En-ráfkv, his price.

Enrahécetv, s., to impute, set to his account, to value.

En-ráhkv, price, worth.

En-rákkē, great.

Enrákkē-stómusen, how great.

En-rakrákkv, president, principal, chief.

En-rámetv, s., to uncover, reveal,

to open.

En-recópetv, s., to loose, free.

En-recópkv, deliverance,freedom.

En-ropottíyetv, s., to bring through.

En-rv'mketv, s., to reveal, make manifest.

Enrv'mkē, revealed, opened.

En-rv'mkv-ránekat-sekon, shall not be revealed.

En-sátetv, s., to choose, to account for. 


\section{ENS}

En-sátketv, s., to choose, gather. En-satkv'ketv, p., to choose, to gather.

En-séf ketv, s., to smell.

Ensehóketv, to cease to be.

En-súkkv, a corn sucker.

En-svcvcákv, a rattle.

En-svtáknv, a cock's comb, his ridge.

En-tacúnketv, s., to lie down before the fire.

En-tálv, a rib, his rib.

En-tekkéyat, have borne, having borne.

En'tis, already, even now.

En-tohkétv, s., to drive for him.

En-tohópkè, a lot; any enclosure, his lot.

En-tóhton, his barn, garner.

En-tokkéketv, s., to kneel to him. En-tvkháketv, s., to go along side.

En-tv'le, the grain, the kernel, its grain.

En-tv'le-es'se, the chaff.

En-tv'lkè, apart, separate.

En-tv'lketv, s., to be apart, alone, separate.

E-nv'cē, his side.

E-nv'cè-tvkhókē, the side below the arm pit.

E-nv'rke, his stomach, belly.

En-yúpv, afterwards, behind.

En-yv'musē, obliging, accommodating.

En-yvmv'setv, s., to accommodate, oblige.

Eoh-akhv'ttetv, s., to shut to.

Eoh-kerkúecetv, s., to confess, acknowledge.

Eoh-wíketv, s., to bear on himself.

E-óketv, s., to fib, to lie, tell a lie.

Ep, us, (for pume or epume.)

Epáken, six.

\section{EPA}

Epáyetv, s., to marry, to lead, take in, have a wife.

E-pes'sē, milk, bag of a cow.

Epéssen-wicécetv, s., to wean from the breast.

Epíketv, s., to be within.

Éplvmē, Abraham.

Epo-fvnkákv, Providence.

Epóh, upon us.

Epóh-feshókófvn, when we are baptized, $i_{\text {. }}$., sprinkled upon. Epóh-kv'lketv, s., to pour upon us. Epoh-yv'rs, let me win.

Ep-okkósvres, shall wash us.

E-poyépetos, was rewarded, had won.

Epóyetv, s., to gain, earn, acquire, win.

Epó-yv'ketv, p., to gain, inherit, acquire.

E-ppúcē, his son.

Eppúcē-er-eppúcē, his son's son.

E-ppúcetákēe, p., sons, his sons.

E-pucáse, his master.

E-pucásekó, free, without a master.

Epu-fástv, our benefactor, preserver.

Epu-hecícv, our guide, our guard.

Epu-hunechúecvs, s., (imperative) wake, arouse us.

Exu-náhis, though we get out.

Epu-piyecícvs, s, (imperative)

cause it to be with us.

Epupv'ketv, s., to be with us.

Epu-pv'kvs, s., (imperative) be with us.

Epu-wahécvs, (imperative) scatter us.

$\mathrm{Er}$, thence, in that direction, towards, at a distance.

Erá, the back, his back.

Era-es'sē, the bristles, $i$. e., the hair of the back. 


\section{ERA}

Era-fúnē, the spine, backbone. Er-ahóyetv, d., to go by. (Erá. yetv. Erápéyetv.)

E-ráhv, his elder brother, or her elder sister.

Era-péswv, tenderloin, flesh of the back.

Ér-apéyetv, p., to go by.

Ér-apvkéyvres, we will go and dwell with him.

Era-setetékv, the bristles.

Era-soh-welépkv, back-band.

Era-vc'vfv'kv, sinews of the loins. Er-áwetv, p., to go from.

Era-wvnv'pv, the upper part of the back.

Er-áyetv, s., (Erahóyetv, Ervpéyetv) to go by.

Er-céyof, when he entered into.

Er-éceyetv, s., to come into.

Er-esáwetv, p., to go after.

Er-ésetv, s., (Vthóyetv, Eresawetv) to go after.

Er-espókat, finally, lastly.

Er-fúlketv, s., to turn back towards.

Er-hecícetv, s., to go and show another.

Er-hocátskē, their offspring, their seed.

Er-honv'psē, their offspring, seed.

Er-honv'psvte, that which had offspring.

Er-hopelhóyvtes, p., they went and buried him.

Er-hopóyetv, s., to hunt afar off.

Er-hoyanécetv, p., to go past.

Er-hoyánetv, s., (Er-hoyanhóyetv, Er-hoyanécetv) to go past.

Er-hoyanhóyetv, d., to go past.

Er'ke, father, his father.

Erkē-mellv'lkē, fatherless, phans.

\section{ERK}

Erkēnv'ketv, s., to preach, to bring good news.

Erke-nv'kv, a preacher, (from herkv, peace, good news,) one who brings good news.

Erke-nvkv'ketv, p., to proclaim peace, preach the gospel.

Erke-nv'kv-sevpáyv, a bishop, overseer.

Er'kucē, stepfather, uncle.

Er-lícetv, s., to go and put away.

Er-líket, being or sitting off at a distance.

Er.liketv, s., to live at a distance, live at.

Er-lvpv'ketv, s., to go and join them.

Er-natásetv, s., to bound, or bounce in going.

Ero, a squirrel.

Ero-ēsko, ground squirrel.

Eróhvtvlv'ket, over and above.

Erórat, leading to, bring from.

E-róretv, s., to come there, arrive at.

Erorícet, arriving, having re. turned.

E-rorín, I arriving.

E-rorv'ketv, p., to come there, get there, bring.

Ero-wíyv, flying squirrel.

Er-topv'rv, after, hereafter.

Er-vlákit,I coming back,returning

Er-vpáketv, s., to be with, join to.

Er-v'tetv, s., (Rvthóyetv, Eráwetv) to go from.

Er-wíyetv, s., to betray, deliver up, to sell.

Er-wiyvte, that which he had sold, betrayed.

Er-yícetv, p., to return.

Es, se or s, as a prefix to a word, means with. 


\section{ESA}

Es-acáyetv, s., to land, draw to shore with.

Es-aháyetv, s., to imitate.

Esáhketv, s., to catch.

Esahopáketv, s., to liken, compare with.

Esahopákv, a parable.

Esahopáyar-haks? Whereunto shall I liken?

Esáhyetv, s., to pretend, imitate, Esakvsv'mkv, a psalm, hymn. praise.

Esapv, a gar fish.

Es-áretv, s., to carry about or with.

Es-ásetv, s., to pursue with.

Esatucénat, third.

Es-áyetv, s., to go in with, to carry.

Es-áyv, a carrier, a porter.

Es-cáukv, a dipper, hence, Tvkunawv-escaukv, draft.

Es-céf ketv, a spur.

Es-cehvlátetv, s., to adjure, to put on oath.

Escēlópíc, "good for you."

Esce-munkewites, you might remain forever.

Es-cén, with you.

Es-c'enyícēs, p., we bring to thee.

Es-cen-hēretáres, it shall be better than for thee.

Es-cesv'perv, s., to flail.

Es-cesvpv'ketv, p., to flail.

Es-céyetv, p., to go. in with, to enter.

Escēyihocv'kvres, p., you shall be brought.

Es-ceyvránetos, p., they are to go in.

Es-cókv, a pen, pencil.

Escóyetv-eshúerv, inkstand.

Es-cúko-hákv, a tent, tabernacle. Escúkolákof, within the tent or house.

\section{ESC}

Es-cv'la, a wagon, a cart.

Es-cvléckv, a wagon, a cart.

Escvléckv-en-cv'llv, cart-wheel, wagon wheel.

Es-cvléckv-tóhkv, a wagoner.

Es-cvléckv-per'ro, a wagon-bed. Es-cvléckv-pv'fnv, a chariot, a

coach, swift wagon.

Escv'llv, a cart, wagon.

Es-cvtv'mken, will fly with me.

Esem-afv'cketvn, his delight.

Esem-vcakátsketos, ye are of more value than.

Esem-wéské, a fan.

Esem-wíyetv, s., to hold it to.

Es-enhvlwéketv, p., to be exalted, higher, greater.

Es-erhv'lwetv, s., to be exalted, higher, greater.

Esenkerkùeckv, testimony against him.

Es-enkv'nhetv, s., to lie in wait.

Es-enrákket, being greater.

Es-epuhunképetv, s., to be num. bered with us.

Es-epuhunkepr'ketv, p., to be numbered with us.

Es'-epvs, s., take me, go with it. Es-erkenv'ketv, s., to preach with. it, to preach.

Es-éssetv, a vessel, a container. Esetápho, cabbage, i.e., broad leaf.

Esetewíketv, divorcement, quitting each other.

Es-fáckvtes, it is finished,fulfilled. Es-fenóketv, s., to shake with, shake hands.

Esfenóyetv, s., to shake hands with.

Esfókv, a hand saw, a saw.

Es-fó-kv-rákko, a large saw, cross-cut saw.

Es-fv'cketv, s., to fulfill, fill up with. 


\section{ESF}

Es-fvlléckvi, a wheel, a spinningwheel.

Es-fvmecíckv, a nutmeg.

Es-fvmóketv, s., to shake one's self.

Es-fvmóyetv, s., to shake another with.

Es-hahóyetv, s., to be made from.

Es-hakíh'ketv, s., to cry for.

Es-haktésketv, s., to snuff with.

Es-halv'tetv, a hook, leading-line.

Ss-hanécetv, s., to rock.

Es-hanéckv, a cradle for child.

Es-hauéckv, a key.

Es-hayéckucē, a Jew's harp, little harp.

Eshayéckv, a harp, fiddle.

Es-háyetv, any tool, an instrument to make with.

Eshécetv, s., to find, obtain.

Eshéckv, a vision.

Es-hecv'ketv, p., to find, obtain.

Es-hēnrusē, nice, pleasant.

Eshócetv, pounder, pestle, beetle.

Eshóhyen, separated, parted.

Es-holatéckv, indigo, bluing.

Es-hopóyetv, s., to grapple with.

Es-hotcíckv, a pen, pencil, ink.

Es-hotcíc'kv-hv'tkē, chalk.

Es-hotcic'kv-nakcókv, a writing book.

Es-hotópetv, paint brush.

Es-hotópkv-seháyv, a bake pan.

Es-hóyetv, d., to take away.

Eshoyv'ketv, p., to take, take away.

Eshoyvnéckv, a purge, cathartic.

Eshoyv'netv, s., to take away, to purge.

Es-hóyvtes, 3d per. sin. perf., he was taken.

Es-húehketv, s., to cry out.

Es-húehkv, a crier, an auctioneer. Es-hvktésketv, s., to snuff.

\section{ESI}

Esíket, having drunk.

Esíketv, s., to drink with.

Es-káf kv, an oar, a paddle.

Eskálevt, Iscariot.

Es-káskv, a comb, razor.

Es-kerríyet, having learned, or discovered.

Eskerkúecetv, s., to advertise, calculate.

Eskerkúeckv, a plan.

Eskérkv, a sign, a mark, token.

Eskérretv, s., to mark, to learn with, also a mark.

Eskerríyet, s., having learned.

E'sketv, s., to drink.

E'sketv, a drink.

E'sketv-emvráhkv, drinks.

$\bar{E}$ sko, a ground squirrel, ground hog.

Es-kófetv-seháyv, a bake oven.

Eskóf kv, an oar.

Es-kofókv, a churn.

Es-kóretv, a drill.

Es-kórkv, a spade.

Es-kótkv, scissors.

Es kúecetv, v. c., to make or persuade to drink.

Es-kuivpákē, the seventh.

Es'kv, a drink.

Eskv, a drinker, a drunkard, also a mink.

Eskv'ketv, p., to drink.

Es-láfkucē, a small knife, pocket krife.

Es-láfkv, a knife.

Es-lafkv-cápko, a sword, long knife.

E's-leko-táyetv, s., to continue to be with.

Es-léskv, cotton cards.

Es-lihóhcekos, do not cover with, does not place it.

Es-lopicákes, they make good with it. 


\section{ESL}

Es-lúekv, a hoe.

Es-lúyetv, s., to hoe with.

Es-lvstéckv, blacking.

Esmok-kícetv, to smoke.

Es-mómet, together with.

Es-morécetv, s., to boil, to fry.

Es-moréckv, a frying pan, a pot.

Es-nehíckv, ornamental.

Es nésv, a merchant, clerk.

Es-nokcáketv, s., to strangle with.

Es-nokcakiket, part. having been strangled.

Es-nucicéckv, an anodyne, laudanum, opium.

Esnvrkéseton, with child.

Es-oh-céyetv,s., to break through. Esohfv'cketv, s., to be fulfilled.

Es-okúcē, a file, small file.

Es-ókv, a file.

Es-ókv-tvpékse, flat file, rasp.

Es-olv'tketv, s., to slide.

Es-opácetv, a shield.

Es-opécetv, vat, wine press.

Es-opunáyē, verbal, oral.

Es-opunáyet, speaking extempore.

Es-ostvpákat, ninth.

Es-otópkv, a grid-iron.

Es-pakkúeckv, leaven, yeast.

Es-pálat, tenth.

Es - pálē - hvmkvntvlákat, the eleventh.

Espánē, a Spaniard, Mexican.

Es-páskv, a broom.

Es-pofucíckv, bellows.

Es-pofucíckv-emv'pe, the handle of bellows.

Espókē, the end, the last.

Espókeko, unfinished, wanting.

Espókv, a finisher, destroyer, comb.

Es-polkúcē, a gimblet.

Es-pólkv, an auger.

Espóyetv, Espoyáketv, to seek after.

\section{ESP}

Es - pu-yekcvkúecvs, im p er. strengthen us with.

Es-puyekénet, holding us with.

Es-pv'cetv, s., to paint.

Es-pvcv'ketv, p., to paint.

Fs.pvkv'ckē, a bunch.

Es-pvtákv, a feather-bed.

Es-recápkv, a reel.

Es-ropóttv; a needle.

Es-rulv'ketv, a punch.

Es-sátetv, compasses.

Es-sátkv, a pencil.

E'ssè, leaves, hair, feathers.

Es-sélkv, a frow, a frower.

E'ssē-s̄ékó, leafless, bald.

Esse-tápho, cabbage.

Essē-telékmē, fur.

Es'setv, Cáwetv, to take.

Es-síkv, paint.

Essókucē, a file, small rasp.

Essókv, a rasp.

Essú, ashes.

Essúksv, above, or with the hip.

Essúmókkv, dust.

Essú-v tehkv, ash-box.

Estak-héckv, a looking glass.

Es-takkéfkv, a shovel.

Es-tákkv, a bed bug, chinch.

Es-takkvnéckv, blister, plaster.

Es-tak-wvnáyv, a tie snake, a fabulous snake of great length and powers.

Estanēe, rank smelling.

Es-tárkv, a loom.

Estaúkv, a boat pole.

E'stē, a person.

Es'te-cáko, the agent.

Estē-cátē, a red man, Indian.

Estē-echúswv-hunvnwv, son of a woman.

Estè-elècē, murderous.

Estē-elēcv, a murderer.

Estē-élvtē, a corpse.

Estē-en-wíketv, an ambassador. 


\section{EST}

Estē-Eppúce, the Son of Man.

Este-fv'tcvn, a just, or righteous man.

Estē-háco, crazy, drunkard.

Estē-hátv-háyv, half breed.

Estē-hérē, good man, a gentleman.

Este-heríckv, graveyard, sepulchre, tomb.

Estē-hopélkv, a grave.

Estè-hunv'nwv, a man.

Estē-hunv'nwv-acekéletv, the fall of man.

Este-hunvnwv-eppúce, son of a man.

Estē-hv'ppo, a camp.

Estè-hv'tkē, a white man.

Estē-hv'tkē-háyv, half breed.

Estē-kérkekot, a stranger.

Estē-kúcē, the elbow, a cubit.

Est-ékv-fúnē, the skull.

Est-ekv-hv'rpè, the scalp.

Estelēê, deadly, murderous.

Estélle-píkv, a shoe, moccasin, boot.

Estéllepikv-wv'nhe, a shoe.

Estellepíkv-wv'nhe - hv'lwat, a boot.

Estélle-sahocáckē, a sock.

Este-lv'stē, a black man, negro.

Estéman, a gift.

Este-merákan, the poor.

Este-merakáteu, also torments.

Estēmérketv, s., to suffer, perish. Estēmerkv'ketv, p., to suffer, perish.

Estēmérkv, punishment, torment. Estemérkv-séko, endless torment. Estemérrē, poor, pennyless. Estemérretv, s., to be poor.

Estemerrícetv, s., v. c., to make poor.

Estemérrus, poor, needy.

Estemérrusēe, rather poor.

\section{EST}

Estemérrvkúecetv, s., to torment. Estémetv, s., to give, cede.

Estemhóye, the gift.

Estémkv, a gift.

Estem-pórv, a witch.

Estempunahóyetv, d., to consult.

Estem-punayécetv, S., v. c., to consult.

Estem-punayecv'ketv, p., v. c., to consult.

Estem-punáyetv, s., to talk together.

Estem-punayv'ketv, p., to talk together.

Estémv, a giver.

Estémv-kérretv, lasciviousness.

Estem-wíketv-háyv, elector, election.

Es t e-náke - hérē - kérrekot, heathen.

Este-nekrícv, person-burner, Satan.

Esténepícetv, s., to sleet.

Esténepíckv, a tool, a plane.

Estenepíckv-rákko, a plane,a tool. Esténkē-vtéhkv, a finger ring.

Esténkē-wesáhkv-píhkv, a ring.

Esténkē-wesáhkv-tēhkv, finger ring.

Esténk-svhepákkv, thimble.

Esténk-v téhkv, gloves, mittens.

Este-pápv, the lion, i. e., person eater.

Es-tépketv, a rod, switch.

Este-póhet, a mighty one.

Este-pvsátkv, a corpse.

Este-pvsátkv-esculéckv, a hearse. Esterá, a person's back.

Este-súlsoke-máhet, great multitudes.

Este-tahíkv, profane blasphemer. Este-téhvket, eunuch.

Este - turófv-pvlv'knv - okkósetv, wash basin. 


\section{EST}

Esteweyícēe, nauseous.

Este-wvnáyv, constable, sheriff. Estē-yópkv, bed bug.

Este--yv'mv-ekv'nv-fúllet, inhabitant of the earth.

Estímv? who? whose?

Estímvn, any one.

Estímvt? who? any one?

Estímvto-estómet, whosoever.

Estófis, ever, never, eternal, sometime, any time, always.

Estófvn, when, anytime.

Estókē, noise.

Estókē-máhe, very noisy.

Estókē-máhe, very noisy.

Estókē-máhen, making a noise.

Estókē-máhetv, s., to make a noise.

Estómaháketv, pass. to be wondered at.

Estomáhē, marvelous, wonderful. Estomáhē-sehonéckvkē, wonderful.

Estomáhetv, s., to wonder at.

Estomákan, p., wonderful.

Estomáketv, p., to wonder at.

Estóman, which.

Estomáten, (astonished) by no means.

Estomátskat? which of you?

Estomátskis, if any of you.

Estómē, what.

Estomécet, how? doing.

Estomécetv, to do.

Estomecv'kvre-te? what shall he do?

Estómen? where? why? what?

Estómet? how? whom? every, in no wise.

Estómeton? how is it?

Estómetos, what manner of.

Estómis, any one, either, else.

Estómis-áretv, Omnipresence.

Estómis-enyv'mvset, neutral.

\section{EST}

Estómis-wákketv, to lie about.

Estomómusē, as much as.

Estómusēkon, not much.

Estómusen, not much, little.

Estómusen? how much?

Estomúsvten, in no wise.

Estómv, any thing.

Estomvránat, going to be.

Estómv-téken? how much?

Estómvten, in no wise.

Estómv-tis, some where.

Estómv-tókos, is nothing.

E'ston? any? any one?

Estónkon, if nothing prevents, any how, necessary.

Estónkos, need not, necessary.

Es-turófv-es-hvsvtéckv, a towel.

E'stos any, any one.

Estos-kométskekot, thou carest not for any one.

Estúcē, a babe, infant.

Es-tv'cetv, a sickle, reap hook.

Estvk-vcwéckv, starch.

Estv'lkē, p., people, persons.

Estvmáhē, enough.

Estvmáhets, it is .enough.

Estv mélk:s, on every side.

Estv'mín? which way?

Estv'mitis, both.

Estv'mv-estómen, whithersoever.

Estv'mvtē? where? which is the way?

Estv'mvtis, any way.

$\mathrm{E}^{\prime}$ stvmv'n? where? whence?

Estv'mvto, where, wheresoever.

Estv'mvto-estómen, wheresoever.

$\mathrm{E}_{\text {‘stvn? where? }}$

Estvtáckv, centipede.

Estvtókv, no where.

Esúksu, side, above the hip.

Ess-vhesáketv, s., to inspire, to pretend.

Es-vhopákv, a parable, simile.

Esv'kcv, the rump. 


\section{ESV}

Es-vkerríckvn, memorial.

Es-v'ketv, p., to catch, take.

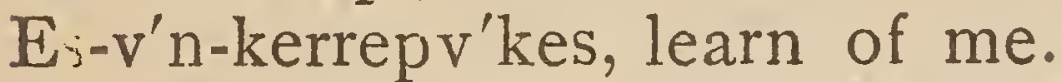

Es-vn-rv'pkv, an accusation.

Es-vpácetv, a shield.

Es-vráhkv, cause.

Es-v'tetv, s., to bring, carry.

Es-wecáletv, s., to sparkle.

Es-wvcátetv, a sickle.

Es-wv'kkē, page.

Es-wvnákv, a strap.

Es-wvnáyetv, s., to tie, bind.

Es-wvnáyetv, a rope.

Es-wv'nkē, bail.

Es-wvnv'kē, bails.

Es-wvnákucē-hv'mken, skein.

Es-yícetv, p., to bring, to come with.

Es-yókv, fine sieve.

Esyomákat, p., both.

Es-yomákusè, they alone.

Es-yóman, with this.

Es-yómat, p., and, together with them.

Esyomát-tes, each one.

Es-yómen, together with.

Es-yómeyat, also, and.

Esyont, with them.

Esyopécetv, s., to sneak along with.

E's-yoposkv'lke, money changers.

Esyopv, sieve, sifter.

Es-yóyetv, to sift.

Es-yukpóyetv, to finish, complete.

Es-yvhíketv, a song, musical.

Esyvhíketv-enhákēe, a tune.

Etáwvn, the same, itself.

Etcáketv, p., to shoot.

Et'cetv, s., to shoot.

$\mathrm{E}^{\prime}$ tcr, a gun, a bow.

E'tcv-háyv, a gun-smith.

$\mathrm{E}^{\prime}$ tcv-kotáksē, a bow.

Etcv'kotáksv, a bowman.

E'tcv-svpáckv, a gun lock.

\section{ETC}

E'tcv-svtáhē, a rifle, i.e., a square gun.

E'tē, Eiten, Etem, apart, asunder, each other.

Etēcákkvtē, his brethren.

Etécetv, s., to make on a fire.

Etēcv'ketv, p., to make on a fire.

Etē-fullátskekv, came yourselves.

Etē-fulléyvtē, we ourselves came.

Etēhánetv, s., to quarrel, jangle.

Etēhánkv, contention, quarrels.

Etē-hanv'ketv, p., to quarrel, jangle.

Etē-hécetv, s., to meet each other.

Et -hórkv, a seam.

Etè-hoyánetv, s., to go abroad.

Etēhóyvnēn, by, by means of.

Etēhoyv'nkv, our streets.

Etë-hv'lvte-puecetv, v. c., s., to. bind, to marry, cause to hold together.

Etēhvrkv'swv, brass kettle.

Etēkerhóyetv, his acquaintance.

Etēkélketv, wrinkle, shrink.

Etēkicvlíketv, s., to say to each other.

Etekkéyetv, to walk with a cane. Etektvnécetv, s., have excused, to permit, grant space.

Etektvnecv'ketv, p., permit, give space.

Etektv'nkē, opportunity, space.

Etekvpáketv, p., to separate, divide.

Etekvpícetv, S., v. c., to separate, set at variance, 'to divide.

Etekvpicv'ketv, p., to separate, divide.

Etekvpv'kē, second time.

Etelíketv, s., to frame together, or builded.

Etelvcv'ketv, p., to join together, agree.

E'tem, Eten, Ete., each other. 


\section{ETE}

Etemécetv, s., to respect, regard. Etem-en-cákē, stingy towards each other.

Eiem-esíkekos, will not drink with each other.

Etemetúecè, respect of, partial.

Etemfátcetv, s., reckon with.

Etem'puna-háyetv, consult together.

Etempunáyetv, to read, consult.

Etem'-vpóket, dwelling together.

Etemvpv'lwusén, all at once.

Etém-wíketv, to deliver up, betray.

Etén, Ete., each other.

Etén-cáke, dear to each other.

Eténetv, s., to stretch one's self.

Etenhelkepúecetv, s., to reconcile.

Eten-hérketv, reconcliation.

Eten-hesícetv, reconciliatiun.

Eten-okécvkē, loving each other.

Etenráwv, between, among, in the mean time.

Eten-rv'pkv, strife, contention.

Eten-tvkhákē, side by side.

Etepáyepúecetv, s., to give in marriage.

Etēpaye-hócetv, d., to give in marriage.

Etēpay'etv, s., to marry.

Etepoy'etv, s., to strive, fight.

Eteropóttē, through.

Eteropóttetv, s., to go through.

Eteropotíyet, having gone through.

Etesétketv, to rend, tear.

Etetáckv, waist, loins.

Etetakúecétskat, you preparing.

Etetákvtē, ready.

Etetakúecetv, s., to prepare, get ready, qualify, ordain.

Etetéketv, the joints.

Etetícetv, s., to prepare.

Eteticv'ketv, p., to prepare.

\section{ETE}

Eteticv'kvtē, prepared.

Etetihv'mkusē, only ready.

Etetvkocíken, burst asunder.

Etewólē, see Tewolē, near together.

Eteyákyvpē, cloven, cleft, asunder.

Eti, other.

Eticáketr, p., to change, repent. Etícetv, s., to change, repent.

Etíckvn, change, repentance.

Etímv, another.

Etímv-ócetv, to put away.

Etkolécetv, S., v. c., to cause chills.

Etkóletv, s., to have chills.

Etkólkv, chills.

Etkolv'ketv, p., to have chills.

Etó, wood, a tree.

Eto-cv'pkē, a pole.

Eto-cv'skv, wood-chopper.

Eto-ēleko, undying wood, mistleto.

Eto-en-cvlókcowv, the gum of a tree.

Eto-enlókcē, fruit.

Eto-es-cvléckv, wagon, a truckwagon.

Eto-esfókv, a saw.

Eto-eskétkv, a saw.

Eto-es-kóf kv, a chisel.

Eto-es-kvláf kv, a drawing knife.

Eto-es-líkat, a grove.

Eto-es-púlkv, an auger.

Eto-es'sē, foliage, a leaf.

Eto-fókv-es-fóyetv, a whip saw.

Eto-fókv-tvpéksē, plank.

Eto-fóyv, a sawyer.

Eto-fvkkv, a grub, or root of tree.

Eto-fv'mpē, a cherry tree.

Eto-fv'skë, a wooden glut, a thorn.

Eto-fv'skē-v'lkan, thorny.

Etoh, to, unto, together. 


\section{ETO}

Etoh-kaletv, S., to assemble, mingle together.

Etóh-kvlíket, having assembled, mingled.

Etóh-kv'lket, growing together, putting together.

Etólh-kv'lketv, p., to assemble, to mingle together.

Etohtvlécet, from place to place. Etohtv'retv, s., to edify, build up.

Etóh-tv'rkēn, buildings.

Eto-hv'rpē, bark of a tree.

Eto-hv'tkē, ash, white ash.

Eto-káckucē, a mote, little piece of wood.

Etokáyetv, s., to bet.

Eto-kultecv'kvten, torches.

Eto-lánē, a green tree.

Eto-lékwē, rotten wood.

Eto-mopúswv, sap of a tree.

Eto-mútkē-svkóskv, wash-tub.

Etónetv, s., to shed itself, one's self.

Eto-nakóftē, a pole.

Eto-ófv, the forest.

Eto óto-v'pē, a chestnut tree.

Eto-póhkè, a shrub, small bush.

Etorkówv, the knee.

Eto-sencv'lv, truck-wheels.

Eto-súlkē, timbers.

Eto-sv-nv'f ketv, a maul.

Eto-tále, dead or dry wood.

Eto.tv'kwè, cork wood, spongy wood, etc.

Eto-tvpéksē, plank, boards.

Eto-v'lkē, a forest.

Eto-wárkē, staves.

Etowetv, s., to pole a boat, propel, compel.

Eto-yákpē, fork of a tree.

Eto-yúksv, tree top.

Et'skē, a mother.

Et'skē-méllē, an orphan.

Etskē-melv'lkē,fatherless,orphans

\section{ETS}

Ets'kucēe his aunt, (i. e., the mother's sister.)

Ets'kv, lice, a louse.

Et'skv-húswucē, gnats,small bugs.

Et'skv-húswv, small flies.

Etskv'lkē, his parents.

Etskv'lkē, parents.

Ettē, fruit.

Ettē-kicáketv, p., to speak well.

Ettē-kó, fruitless.

Ettop'ketv, s., to scorch.

Ettopkv'ketv, p., to scorch.

Ettúecetv, s., to bear fruit.

Ettuecv'ketv, p., to bear fruit.

Ettv'kekot, unfruitful.

Etúecetv, s., to make it differ.

Eturófv, the face, his face.

Etusē, quite another.

$\overline{\mathrm{E}} t \mathrm{t}$, another, other.

Etvkkv'lkē, joined together.

Etvkpv'fketv, s., to dust one's self.

Etvlofv'lket, s., his citizens.

Etv'lwv, his town or tribe.

Etvmímvn, another way.

Etvmin, another way.

Etvpalv, the other side.

Etvpómat, being as, same as.

Etvpómen, so as, the' same, in like manner.

Etvpómetv, s., to be as, or equal to.

Etypómusen, so as, in like manner.

E-tv'rpv, his wing, a wing.

Etvsē, a little different.

Eu, (a suffix to the end of a word) and, also.

E-vketécetv, self examination.

E-vketécetv, s., to examine one's self.

E-vpáyetv, to lead, take with, to follow, accept.

Evpáyv, a leader. 


\section{EWE}

Ewetv, to scorn.

Ewe'yè, scornful.

E-wícetv, v. c., s., to make himself leave.

E-wíketv, s., to leave one's self, to leave off.

Ewvkátv, a sawyer, worm-borer. Ew'nhkē, thirst.

Ewv'nhketv, S., to thirst.

Ewv'nwv, his sister, or his cousin. Eyacáketv, p., to want, greatly desire.

Eyáceko, does not want,needless. Eyáces, needful, necessitous, or he wants.

Eyácetv, s., to want, desire.

Eyáckē, desire, want, lust.

Eyacv'ketv, p., to want, desire, lust after.

Eyáskakusátē, p.. the meek.

Eyáskē, meek, humble.

Eyáskē-lekúthē, mild, meek.

Eyásketv, humility, meekness.

Eyasketv, s., to be humble, mild, meek.

Eyáskusē, very humble, harmless.

Eyaskusétskat, you who are humble.

Eyáskvkēn, being humble.

Eyaskv'ketv, p., to be humble.

E-yekcicetv, s., to brace himself, to strain himself.

E-yuksehnicetv, s., to give one's self a cold.

Eyuksícetv, s., to endure to the end.

Eyuksicv'ketv, p., to endure to the end.

E-yúpo, his nose.

E-yúpv, behind him.

Eyúpv-ócetv, s., to put behind.

E-yvketécetv, s., to examine one's self.

E-yvketec'kv, self-examination.

\section{EYV}

Eyv'ppē, his horn.

Eyvtúecetv, s., to be bashful.

Eyvtuecv'ketv, p., to be bashful.

\section{F.}

Faká, a hunt, a chase.

Fákke, soil, loam, dirt, clay.

Fákke-nórkv, brick, burnt clay.

Faláh-le, split in many parts or places.

Falowá, marrow.

Falvlécetv, v. C., to cause to split.

Fálvncv'lkē, p., Frenchmen.

Falv'petv, s.; to split, cleave, p.,

Falvpketv.

Falv'pkē, split, cloven.

Falv'pketv, p., Falv'petv, s., to split, cleave.

Fápetv, s., to singe.

Faslétsken, for vfasletsken, you doing indeed.

Fátcof, when it is settled.

Fátcusēe, truly.

Fayátv, a guide.

Fayépv, a hunter, a horse-fly catcher, gad-fly.

Fáyetv, s., to hunt game.

Fáyv, s., a hunter.

Fayv'ketv, p., to hunt game, turn to one side.

Fayv'lkē, p., h'nters.

Fayv'tetv, s., to turn, to guide. Fayv'tke, turned to one side. Fayv'tkv, a governor of a ship. Fecv'petv, s., to loose, untie.

Fecv'pketv, s., to be loose.

Fehpucē, a fife.

Féhpv, a flute, trumpet, harp. Fekapépetv, s., to take rest, be easy.

Fekáyetv, s., to sow seed.

Fekáyv, a sower of seed.

Fekayv'ketv, p., to sow seed. 
FEK

Fekcákhē, jealous, afraid, skittish.

Fekcakhécetv, s., to cause to fear.

Fekcē, entrails, intestines.

Fekcē-semvtéhke, sausage.

Féke, the heart.

Fékē-fv'kv, artery.

Fekekákat, palpitation of the heart.

Fekéketv, the palsy, pulsation of the heart.

Fekéketv, s., to tremble, to shake.

Fekekísem, though without pay.

Fekékusē, trembling.

Fekekv'ketv, p., to shake,tremble.

Fekekv'petv, p., to rest.

Féke-nókkè, grief, heart pain.

Feképetv, s., to rest.

Feképkv, rest.

Feképkv-néttv, rest day, the Sabbath.

Fékē - séko, heartless, hollowhearted.

Feketemtékucē, pulse, the pulse.

Féketv, s., to pay, reward.

Féketv, pay, reward.

Fek-hē'reko, restless.

Fek-heríceko, tossed about, troubled, cannot rest.

Fek-hērvkekátes, they were troubled.

Fek-hunnē, pensive, resting.

Fek-húnneko, uneasy, unrest.

Fek-hunnépetv, so, to lodge, rest.

Fek-húnnetv, s., to stop, to wait, rest, lodge.

Fek-hunnícetv, v. c., s., cause to rest, to keep back.

Fek-hvme-cícetv, v. c., s., to make bold.

Fek-hv'mkè, bold, courageous.

Fek-hv'mkeko, modest, bashful, diffident.

\section{FEK}

Fek-hv'mkē-oháyetv, to dare, be bold.

Fek hv'mketv, s., to be bold, to dare.

Fek-nókke-máhē, remorse, great sorrow.

Fek-sumécet, an uproar.

Fek-sumécetv, v. c., s., to frighten, make an uproar.

Fek-sumecv'ketv, v. c., p, to frighten, make an uproar.

Fek-súmketv, s., to fear, be troubled.

Fek-tácketv, s., to pant, be short winded.

Fekv'petv, s., to rest.

Fekv'pkv, rest.

Fenécetv, v. c., s., to blaze, make a blaze.

Fenkákat, fiery.

Fénkē, a blaze, flame.

Fénkes, it is blazing.

Fénketv,s.,to blaze,(as lightning).

Fenkóf, when it blazes or flames.

Fenókē, limber, shaking.

Fenóyetv, s., to shake.

Fénv, a crossing log, bridge.

Fépē, a gourd, calabash.

Fépetv, s., to ravel out.

Fépkv, raveling thread (of cloth) ravelings.

Fepkv'ketv, p., to ravel out.

Fesáhē, spotted, motly, speckled.

Fesáhlē, a flash.

Fesáhletv, s., to flash.

Fesáhusē, spotted, speckled.

Fesálécetv, s., to sprinkle.

Fésketv, s., to sprinkle, scatter out.

Feskv'ketv, p., to sprinkle, scatter out, shed forth.

Féttv-totopéksē, threshing floor. Féttv, the yard, out of doors, threshing floor. 


\section{FET}

Fetúkkv, the yellow -hammer, a bird.

Feyeyékē, curly, a screw.

Feyeyékusē, small screw.

Feyícetv, s., to exact, make pay.

Fihnē, running, streaming, an issue.

Fihnécetv, s., to drain, pour out.

Fíhnē-múnkv, a fountain.

Fihnetv, s., to flow, pour out.

Fínne-yékcv, rapids, swift current.

Fikè, twisted.

Fíkv, twisted.

Fiyáketv, p., to be temperate.

Fiyátetv, s., to be temperate.

Fiy'etv, s., to twist, pervert.

Fiyíket, turning aside.

Fiyv'ketv, p., to be twisted, unruly.

Flitē, Friday.

Fo, a bee, bees.

Fo-cátē, wasp (i.e., a red bee.)

Fo-em-mékko, king bee.

Fo-en-cv'mpè, honey.

Fóhketv, s., to blow or sound like wind.

Fo-húerv, sweat bee.

Fo-hútē, bee-hive, honey comb.

Fokáyetv, s., to sow, scatter.

Fokayv'ketv, p., to sow, scatter. Fo-lánē, yellow jacket.

Fo-lókv, bee-martin.

Fo-lv'hpv, muscle shell.

Fo-nēhá, bee's-wax.

Fotenétkē, a bumble bee.

Fótketv, s., to whistle.

Fotv'kletv, chicken-pox.

Fotv'kletv-ome, nettle rash.

Fo-uecáwv, a drone bee, water carrier.

Fóyetv, s., to saw, to peel, husk. Fúco, a duck.

Fúco-ecústake, duck's eggs.

Fúco-hunv'nwv, a drake.

\section{FUC}

Fúco-súlē, Muscovy-duck.

Fulécetv, s., V. c., to make turn back.

Fulecícetv, s., v..c., to make come back.

Fúletv, s., to turn, turn back.

Fulhóyetv, p., to carry about.

Fulhúecetv, p., v. c., to make turn back.

Fúlketv, s., to turn back.

Fúllan, the air, i.e., hvlwe-fullan.

Fúlle, the whole.

Fúllekvs, let them alone.

Fúlletv, p., Weláketv, d., A'retv, s., to go about, to be.

Fulléyvrē, being here, being abo: $t$.

Fúllvten, were about.

Fulópa, pimples.

Fulóp tvpékse, the shoulder blade.

Fulópv, the shoulder.

Fulotécetv, s., v. c., to make turn, to convert.

Fulótetv, s., to surround, to turn.

Fulótkē, around.

Fulótketv, p., to turn around, to grind.

Fúlowv, the shoulder.

Fulv'hpv, muscle shell, clam, etc.

Fulv'p

Fulv'petv, s., to split, cleave.

Fúnè, a bone.

Fúnē-líkv, bone set, thoroughwort.

Fúnē-tihókv, rheumatism.

Fúnē-tv'lkē, bony, raw-boned.

Fús-cátē, red bird.

Fus-em-poknv'kv, bird's nest.

Fus-hv'tke, white bird.

Fus-lánē, yellow bird.

Fus-okholátē, blue bird.

Fus-svháyv mocking bird.

Fúswv, a bird. 


\section{FUS}

Fúswv-hútē, bird's cage.

Fuyúcke, the crown of the head, i. e., curl.

Fvcécetv, s., to fill.

Fvcecv'ketv, p., to fill.

Fv'cfvkè, p., full.

Fv'ckē, s., full.

Fv'cketv, s., to be full.

$\mathrm{Fv}^{\prime} \mathrm{cv}$, the collar bone.

Fv'kv, a rope, vine, string, cord.

Fvláhletv, s., to rend, to split.

Fvlásko, a flask, bottle.

Fvláskucē, a vial, small bottle.

Fvláwv, the brim or mouth.

Fvlécetv, s., to empty.

Fvlecv'ketv, p., to empty.

Fvléknē, s., twisty, not level.

Fvlenfv'kē, p., twisty, not level.

Fvllécetv, s., to spin.

Fvlléckv, yarn, thread.

Fvllécv, a spinner.

Jivllēev'ketv, p., to spin.

Fvllehóle, tossed to and fro.

Fvlvlicetv, s., to twist.

Fvlvlíckv, twisted.

Fvlvlicv'ketv, p., to twist.

Fvlvlv'kē, curls, twisted.

Fvméce, sweet smelling.

Fvmécusat, sweet smelling.

Fvmécv, a musk-melon.

Frmóyetv, s., to shake.

Fvmoyícetv, v. c., s., to cause to shake.

Fv'mpē, bad smelling, stink.

Fv'nkē, projecting, partly uncovered.

Fv'nketv, s., to domineer, rule over.

Fvnkíyetós, I am higher, above.

Fvsécetv, s., to sharpen.

Fvs'ke, sharp, keen edge, darts.

Fv'stvk-áyē, for A'fvstvkáye, I attend to them.

Fvtcákē, being settled, righted up.

\section{FVT}

Fvt'cē, right, righteous, honest.

Fvtcécetv, s., to justify, correct, settle, arrange.

Fvtcēcícetv, s., v. c., cause to correct, justify, make right.

Fvtcéckv, judgment.

Fvtcec'kv-néttv, judgment day.

Fvtcēcóf, when he decides, makes

it straight.

Fvtcécv, a judge, advocate, undertaker, proof.

Fvt'cekvs, let that decide or make it right.

Fvt'cetv, righteousness, integrity. Fvt'cetv, s., to judge, settle, straighten.

Fvt'cv, the right, righteousness.

Fvtcrlíkè, noon, mid.day.

Fvtcvlík-hoyánen, afternoon.

Fvtcvlík-óreko, forenoon, (not noon).

Fvt'cvliks, it is noon, mid-day.

Fvt'cvn, directly, in a straight course, steadfastly.

Frt'cunoks, is righteous.

Fvt'cv-nv'nk-kétskes, you did right.

Fvt'cvres, it will be corrected, made right.

Fvt'cvt, it is certain, right, straight.

Fvt'cutókos, it is not right, it is improper.

Fvtósecícetv, s., v. c., cause to bounce, spring.

Fvtos'ketv, s., to bounce, spring up.

\section{H.}

Hácē, drunk, crazy, resolu:e, daring.

Hacécē, drunk, crazy.

Hacécetv, s., v. c., to make drunk, crazy, etc. 


\section{HAC}

Hacekó, not drunk, temperate. Hacetékv, salámander, gopher. Hácetv, s., to get drunk.

Hackvcéskv, temple.

Háco, active, crazy, also a title -Colonel.

Hacoháketv, s., to act foolishly, madly, etc., epileptic.

Hacohákusē, a little crazy, rather foolish.

Hacohv'kē, p., mad, crazy, foolish.

Hacuklepá, green lizzard.

Hacukrv'nwv, a spider.

Hahcékwv, fish-hawk.

Hanicetv, v. c., p., to make.

Hah'ketv, s., to whoop bawl.

Hahóyetv, p., to be made.

Hakákat, made.

Hakáten, having made.

Hakcēlopótketv, s., to be upset.

Hákcelopótket, headlong, being upset.

Hákē, made.

Hake' noise, sound.

Hákeko, unmade, not made.

Hake'ko, unsounded, noiseless.

Hákemvts, was m ıde, (long ago.)

Hákes, is making.

Háketv, s., to blow the horn, to sound, to crow.

Hakíhketv, crying, a cry.

Hakíhketv, s., to cry, to weep.

Hakihóketv, p., to cry, weep, lament.

Hakíst, for Hakisést, was sounding.

Hákiyaté? Was I made?

Hákkucē, a little spoon.

Hákkv, a spoon.

Hákkv-rákko, big spoon, gourd, dipper.

Hak-ófvn, when it is sounded.

Hakókof, when sounded.
HAK

Hákpvtē, niece of a man.

Haktésketv, s., to sneeze.

Hákv, the factory, where anything is made.

Hakv'ketv, p., be made, become. Hákvkv'cvs, p., you must be mad. Hálo, tin cup, tin, a cup.

Halo- $f v^{\prime} c k \bar{e}$, a pint.

Hálo-fv'cke-hv'mken, one pint.

Hálo-palv'knv, tin pan.

Halv'tetv, s., to catch, draw, pull. Hánetv, s., to curse. defame.

Hanv'ketv, p., to curse, jangle.

Hauécetv, s., to open, as the mouth, the door, etc.

Hauecv'ketv, p., to open the mouth, the door, etc.

Hauhv'kē, p., holes, doors, openings.

Hauhv'kvtes, opened, is opened. Haúkē, s., hole, door, an opening. Haukv'kvres, it shall be opened. Haúkvtes, s., is opened.

Haú-vháyetv, s., to be, or to breathe open mouthed.

Hau-v'kle, open-mouthed.

Hauvklécetv, v. c., s., to open the mouth, to gag.

Hayaketv, s., to mock, jeer.

Háyatskísem, p., though you make.

Hayéckv, a violin, fiddle.

Hayépis, s., I have made.

Háyetv, s., to make, produce.

Hayóhketv, s., to shout in exultation.

Háyv, a maker.

Hayv'ketv, p., to make.

Hècē, seeing.

Hécē, tobacco.

Hécē-ahákē, mullein.

Hecéko, blind, cannot see.

Hecélwv, poplar tree.

Hécē-pápv, tobacco-worm. 


\section{$\mathrm{HEC}$}

Hecépetv, s., to see, to look for. Hécepvkwv, a pipe.

Hécetv, s., to see, to look for, to read.

Hécetv, a lesson.

Hécetv-taye, to gaze, read earnestly.

Hecícetv, s., v. c., to show, to cause to read.

Hecíken, having received.

Heckàkat, possessed, obtained.

Heckakúecetv, s., v. c., to beget, obtain.

Hec'ken, openly, in sight.

Hec'ke!v, s., to appear, be born. Héckof, when it appears, is born.

Heckúécetv, s., to beget, obtain, be born, appear.

Héckv, countenance.

Héckv'ketv, p., to appear, to receive, be born.

Héckvránē, about to appear, be born.

Héckvránvten, inheritance.

Héckvren, it might appear.

Héckvte, received, the birth.

Héckvtē-nettv, birthday.

Hecv'ketv, p., to see.

Hecvluécetv, p., v. c., to show, cause to see.

Hefépē, a gourd.

Héf kè, steam, vapor, mist.

Hehetv, s., to bellow.

Héhketv, s., to growl.

Hehkv'ketv, p., to growl.

Hēkok'ketv, s., to hiccough.

Hēkús, or Hekúst, no, or it is not.

Hēlaksécetv, s., to deny, contradict.

Héles-cerēhócē, pills.

Héles-hómo, quinine.

Héles-hv'tkē, calomel.

Héles-nehá, castor oil.

\section{HEL}

Héles-okcv'nwv, salts.

Heléswv, medicine.

Heléswv-ēmetv-hv'mkat, a dose of medicine.

Héleswv-eskúecetv, s., to drench with medicine.

Heles'wv - es - yekcícetv, tonic, strengthening medicine.

Heleswv-nokóf tusē, a pill of medicine.

Helúk-fvmécv, sweet gum, myrrh. Helúkwv, sweet gum, (i. e., to chew) frankincense.

Helúk-wvpē, sweet gum tree.

Helvpá, ring-worm.

Helv'pkè, glib spoken, punctual. Hemómokēe, buzzing.

Hemomóketv, s., to buzz.

Hencusétsketos, you do surely see.

Henká, yes.

Henkístvnts, an omen.

Héno, maple.

Heno-cv'mpv, sugar maple.

Hēnrákē, p., good.

Hen'wē, tracking.

Hepétkè-etkólet, fever and ague. Hepétketv, fever.

Hepetketv, s., to have fever.

Hepétketv-láne, yellow-or bilious fever.

Hērakekátes, it is not good.

Hērákv, fine, good.

Hērē, good, nice, pretty.

Hērē-háyetv, s., to deck, perfect, reform.

Hērekó, faulty, not good.

Hēremáhē, very good, important.

Hēremáhest, the best.

Hēres, s., is good.

Hēretá, very good, the best, godliness.

He'retv, s., to be arduous, clever, to be good. 


\section{HER}

Hērícet, being careful.

Herícetv, s., to make good, to mend.

Hēríket, making peace.

Hërkepúecetv, to reconcile, make peace.

Hērket, being peaceable.

Hērketr, s., to be peaceable.

Hērkv, peace, grace, glory.

Hérkv-háyetv, s., to appease, make peace.

Heromákan, benefactors.

Herómē, kind, faithful, industrious, smart.

Herómekó, unfaithful, ungenerous.

Herómetv, s., to give alms, be kind, faithful.

Herómkv, alms, grace, kındness, favor.

Heromv'ketv, p., to give alms, be kind, faithful.

He'rus, nice, pretty.

Hè'rusē, very nice, handsome.

Hērv'kè, p., good.

Hērv'ketv, p., to be good, very good.

Hesahúecetv, v. c., s., to save, cause to live.

Hesahuéckv, salvation.

Hesahúecv, p., Savior, (i. e., of many.)

Hesahuecv'ketv, p., v. c., to save, cause to live.

Hesákē, alive, living.

Hesákeko-ómet, lifeless.

Hesáket, p., is living.

Hesakétskvres, thou shalt live, be saved.

Hesáketv, life, breath.

Hesáketv, s., to live.

Hesáketv-elécē, phthisic, asthma. Hesáketv-ēlét, to pant.

Hesáketvmese, God, the giver or taker away of life.

\section{HES}

Hesáketvmesē-ahakv'lke, gods, false gods, idols.

Hesáketvmesē-éme-tvlófv, kingdom, (or town) of God.

Hesáketvmesē - enhocéf kv - satvhíket, to blaspheme.

Hesáketvmese- - enhómpetv, the Lord's Supper, the eucharist.

Hesáketv-yúksv-séko, immortality, eternity.

Hesakíye, I living.

Hesákvretók, for he shall live.

Hesayécv, s., Savior, (i.e.e, of one person.)

Hesáyetv, s., to save.

Hes-pv'kwv, a robin.

Héssē, s., a friend.

Hessíyet, having made friends.

Hessv'lkē, p., friends.

Hetúte, frost, ice, snow.

Hetútē-es-oh-hvlátetv, a sleigh.

Hetútē-nérkv, hail.

Hetútē-rákko, snow.

Hetútetv, s., to snow.

Héyv, this, here.

Heyv'mv, hither, here.

Heyv'mvn-áhtes, come here.

Héyvn, here, this.

Héyv-ófv, herein, in this.

$\mathrm{Hi}$ ? what? sir?

Híhketv, s., to groan, growl, sigh.

Hihóye, hot.

Hitákē, p., wives.

Hiwv, wife.

Hiyákēkófv, p., when they did not make.

Hiyákpo, prairie.

Hiyákpo-hv'tke, a ball play ground.

Hiyatíke, being day light, morning.

Hiyáyícetv, s., to shine.

Hiyáyvhóketv, pass. to be en. lightened. 


\section{HIY}

Hiyáyvkē, light.

Hiyáyv'ketv, p., to shine.

Hiyáyv'kusē, bright, very clear.

Híyē, hot, warm.

Hiyetá, very warm, hot.

Híyetv, s., to be warm, hot, get warm.

Hiyó, harvest, summer.

Hiyo-háket, the crop, fruitful.

Hiyo-lókcv, goose-berry .

Hiyómat, now.

Hiyómē-vlakúecet, hitherto.

Hiyóme-cátskvres, you will do so.

Hiyomécetv, s., to do thus.

Hiyómen, thus, after this manner, now.

Hiyomófvn when it is thus, now.

Hiyón,(contraction for Hiyomen) thus, so, now.

H'yo-palécv, the rose.

Híyo-rákko, August, (i. e., big harvest).

Híyuce, July, (i.e., little harvest).

Híyusēe, s., warm, hot.

Hiyv'ke, p., little warm, hot.

Hiyvtíkof, when it was morning, in the morning.

Hiyv'tkē, morning.

Hiyvtkvránet, being a guest, spending the day with.

Hiyv'tkvrén, that it may be day.

Hocácetv, to create.

Hocáckat, that which is created, begotten.

Hocē, pounded, beaten.

Hocēfétskus, don't you name it. Hocéfetv, s., v. c., to cause to name, to swear.

Hocéfkv, name.

Hocéfkv'ketv, p., to name, to swear.

Hocéf kv-hopv'netv, to defame. Hocéf kv-tohkv'letv, to enroll.

\section{$\mathrm{HOC}$}

Hocéf kv-tv'lket, nominal.

Hocéf-séko, nameless.

Hocétv, s., to beat, pound.

Hocéwv, the navel.

Hóckē. pounded, ground.

Hóckvtè, meal, grits.

Hóckvtē-hv'tkē, flour, white meal.

Hocv'cke, creature, creation.

Hocv'ckek-ófvn, when it was not created.

Hocv'cketv, s., to be created, born.

Hocv'ketv, p., (Hocetv) to pound, beat.

Hofehóyetv, d., to stretch the legs.

Hoféletv, s., to kick back.

Hoféyetv, s., to stretch the legs.

Hofóletv, s., to spring forward.

Hofúnē, long ago, a long time.

Hofúnē-nak - afvstv'lkēe, old customs.

Hofúnof, by-and-by, after a while. Hofúnusē, in a little while.

Hofunv'lkè, the ancients, them of old time.

Hohíket, having called, crying out.

Hohíketv, s., to call together, inquire, cry out.

Hohikv'ketv, p., to call together, inquire, cry out.

Hóhseketv, s., to forget.

Hoh'sekos, not forget.

Hokcéwv, musk of skunk.

Hoketésv, a kind of dance.

Hókketv, s., to eat anything dry.

Hokkóla? both? two?

Hokkólen, two.

Hokkolícetv, s., had two, double minded.

Hokósē, small, child-like.

Hókpē, the breast. 
HOK

Hókpē-hopv'nkē, inflammation of breast.

Hókpē-senhvlátkv, martingales.

Hókpē-svlíkv, a brooch, breastpin.

Hókpē-svrvnákv, breast-plate.

Hókpvcv'nhv, the brisket.

Hoktárē, adulterous, fornication.

Hoktárekófvn, not in adultery.

Hoktarétskvs, "Thou shalt not commit adultery."

Haktáretv, s., to commit adultery.

Hoktáret, committing adultery.

Hoktárkv, adultery.

Hoktarv'kè, p., harlots, adulterers, adulterous.

Hoktárv, s., an adulterer, adulteress.

Hóktē, s., female, a woman.

Hóktē-ahákē, effeminate.

Hóktê-epayvránat, the bridegroom.

Hóktē-hunv'nwv - kérrvte - sekót, a virgin.

Hóktē-vcákv, a lady, a fine woman.

Hoktúcē, a girl, little woman.

Hoktv'kè, p., females, women.

Hoktvkē-oyev'lkē, p., widows.

Hóktvle, an old woman.

Hoktv'l-kúlowv, the old woman who catches hold and sticks to a person.

Hoktv'lkv, old age, (of a woman).

Holákwv, soft shell turtle.

Holánetv, s., to ease one's self. (to cover the feet.)

Holáttē, blue.

Holócē, bright.

Holócetv, s., to glisten, shine bright.

Holvcetv, s., to covet.

Holv'ckv, covetousness.

Holwahókē, p., bad ugly.

\section{HOL}

Holwahóketv, p., to be bad.

Holwáketv, s., to be bad, etc.

Holwakē, s., bad, ugly, unpleasant.

Holwákvkes! woe! it is bad. Holwayécē, wicked, cruel, mean. Holwayéckv, sin, unkindness. Holwayécv, s., a sinner, wicked person.

Holwayecv'kè, p., wicked, cruel. Holwayecv'lkè, p., sinners, etc.

Homá, pepper.

Homa-cáté, red-pepper.

Homáhtv, high, a chief, a leader. Homákē, p., bitter, (s., Homē.)

Hóma-lv'stē, black pepper.

Hóma-lv'stucē, little black pepper.

Hóma-setéhkv, a pepper box. Homé, s.. (Homake, p.,) bitter.

Homecáketv, p. to hate, despise. Homécetv, s., to hate, despise. Homecícetv, s., to go abroad. Homéckv, abomination, the hate. ful, cursed.

Homéyecv'lkē, p., aborigines.

Homokē, p., bitter.

Hompépetv, s., to eat.

Hompetá, victuals.

Hompetá-cáukv, p., rations.

Hompetá-enhompéckv, tonics.

Hómpetv, s., to eat.

Hómpetv-hákv-cúko, a kitchen.

Hómpetv-háyetv, s., to cook.

Hómpetv-háyv, a cook.

Hómpetv-rákko, a feast.

Hompícetv, v. c., s., to feed, make eat.

Hompicv'ketv, v. c., p., to feed, cause to eat.

Hompícv, a feeder.

Hompv'ketv, p., to eat.

Hompvkúecetv, s., v. c., to feed, cause to eat. 


\section{HOM}

Hóm $v$, before, in presence of, forward.

Hómv-awolícv, neighbor.

Hómvhéckvtē, the first born.

Hómvhótetv, p., to go before.

Homv'htetv, s., to go before.

Homv-sohpáckv, an apron, (i.e., put before.)

Honécē, wild.

Honéckvkē, wild.

Hónnv, a dress, a frock.

Hónnv-hákē, dress material.

Honokē-yékcē, hemp, flax.

Hónretv, s., to twist together.

Honríyetos, having hoped.

Hónrv-cókwucē, humming bird.

Honrv'kēn-omáte, if it is foreign.

Honrv'ketv, p., to hope.

Honv'psē, offspring, seed, generation, heir.

Honv'psetv, s., to multiply thy seed.

Honv'psécetv, s., to be profitable, to cause your offspring to increase.

Honv'pse-hērēe, prosperous.

Hónwetv, s., to smell.

Hopánē-sekón, without cause.

Hopéletv, s., to bury.

Hopelhóketv, p., pass. to be buried.

Hopélketv, p., to bury.

Hopélkv, a grave, sepulchre.

Hopelv'kekvs, let them bury.

Hopérē, fog, mist, vapor.

Hopiyátē, foreign, far off.

Hopíyē, far, far away.

Hopiyetá, very far off.

Hopokét, chosen (from Hopoyetv, to seek, choose.)

Hopóketv, s., to choose, elect.

Hoporenè, wise, sensible.

Hoporéneko, unwise, senseless, foolish, a fool.

\section{$\mathrm{HOP}$}

Hoporénē-máheko, imprudent, not very wise.

Hoporénetv, s., to be wise.

Hoporénis, though wise.

Hoporénk'v, wisdom, sense, prudence, wit.

Hoporénusē, solemn, rather wise. Hoporēnv'kè, p., wise, prudent.

Hoporēnv'ketv, p., to be wise.

Hopotécetv, s., to set the woods or prairie on fire.

Hopótkétv, s., to burn the prairie, (i.e., one's self.)

Hopóyetv, s., to seek after, choose.

Hopóyv, s., a seeker.

Hopoyv'ketv, p., to seek after.

Hopúe-ahecícetv, s., to nurse, take care of.

Hopúetákē, p., children.

Hopúetak-hutē, the womb.

Hopúetákucē, p., little children.

Hopúewucē, s., a little child.

Hopúewucè-ahecícr, a nurse.

Hopúewv, s., a child, his nephew.

Hopv'netv, s.. to destroy, spoil, break up.

Hopv'nketv, p., to destroy, spoil, break up.

Hóretv, s., to be slothful.

Horkásv, companion.

Hórkē, slothful.

Horkétv, p., to be slothful.

Horkópetv, s., to steal, pilfer.

Horkopícetv, s., v. c., to cause to steal, accuse of stealing.

Horkopicv, accuser of the thief. Horkópv, a thief, robber.

Horkópvrē, rogueish, thievish. Horkópvrē-ómē, thievish, as a thief.

Hor'rē, war, an enemy.

Hórre-mátv'kē, bed bug, chinch, $i$. e., head warrior. 


\section{HOR}

Hórrē-tohópkē, a fort, barricade, garrison.

Horrétv, s., to engage in war, to war.

Hosekán, will not forget, err, deceive.

Hósè, lost, forgotten.

Hósetv, s., to forget, err, lose.

Hosícetv, s., v. c., to make err, to deceive.

Hosicv'ketv, p., v. c., to deceive, cause to err.

Hósketv, p., to forget, deceive.

Hosv'ketv, p., to forget, to err.

Hótcē, a writing, something written.

Hótcetv, s., to write, to inscribe.

Hotcícetv, S., v: c.. to cause to write.

Hotcíckv-svhopákv, a copy in writing.

Hotcícv, a scribe, secretary,clerk. Hóte-hoyícusē, a little speckıed. Hótkē, feathered.

Hotópetv, s., to etch, paint.

Hotosákat, p., being tired, faint. Hotosáketv, p., to be tired, faint. Hotosé, s., tired, wearied.

Hotósetv, s., to be tired, to faint. Hotosícetv, v. c., S., to make tired, cause to faint.

Hotóskv, si, weariness, fatigue, burden.

Hotosv'ke, p., tired, we ried.

Hotosv'ketv, p., to be tired.

Hótskv'te, meal, grits, that which is pounded.

Hótskvte- - hv'tkēe, flour, white meal.

Hottópkv, hives.

Hotúpetv, s., to barbecue, broil. Hótvlè, the wind, air.

Hótvlē hoyánv, hurricane, gale.

Hótvle-hv'se, February, i.e., wind month.

\section{HOT}

Hótvlē-rákko, a hurricane, a gale. Hotv'letv, S.: to blow, as the wind.

Hotv'letv, windy.

Hotv'netv, s., to plait, plat.

Hotv'nkē plaited.

Hoyánē, past.

Hoyánen, more, after, past.

Hoyánetv, s., to pass or walk by. Hoyánet, passing by, or off.

Hoyánof, when it passed.

Hóyetv, s., to give.

Hóyv, a net, a seine.

Hoyv'ketv, p., to give.

Hoyvnákvtē, passed by.

Hoyvnécetv, s., to make pass

by, to purge.

Hoyvnecícetv, v. c., s., to make pass by, evacuate.

Hoyvnécv, weeping willow.

Hoyvnépetos, already, past.

Hoyvnépetv, s., to pass away.

Hoyvnéps, already, past.

Hoyv'ne-táyē, passable.

Hoyv'netv, s., to pass by, past already.

Hoyvnhúecetv, v. c., p., to cause

to pass, to purge.

Hoyvnv'ketv, p., to pass by.

Hoyv'nvres, it will pass.

Hóyvtēt, was given.

Hoyv'tetv, s., to give.

Húébkè, calling.

Huéhketv, s., to call to, shout.

Huéhkusè, eager in calling.

Huéhkv'ketv, p., to call to, call after.

Húerēe, standing.

Huéreko, not able to stand, oysters.

Huerépetv, s., to stand.

Huéretv, s., Sehóketv, d., Svpákletv, p., to stand up, to be stable. 


\section{HUE}

Huerícetv, v. c., s., to make stand, to deliver up, deliver up, make rise up, betray.

Huériyet, rising up.

Hunécē, s., wild, skittish, (ap: plied to tame animals.)

Hunecv'kē, p., wild, skittish, (applied to tame animals.)

Hunemáhetv, to be very heavy.

Hunerá, the North.

Hunhóyē, p., heavy.

Hunhóyetv, s., to be burdened, heavy laden, twisted.

Hunhoyúsvkatéhkvn, he a v y laden, you who are much burdened.

Hunitet, having grown.

Hunkv'tképvkēs, be ye numbered

Húnnē, heavy, weighty.

Hunrákeyē, we hope:

Húnretv, s., to hope.

Hunrv'ketv, p., to hope.

Húnte, s., growing, sprouting.

Húntetv, to grow out, to sprout.

Huntícetv, v. c., to make grow.

Húntv, interest, increase.

Huntv'ke, p., growing.

Hunvntáke, p., males, men.

Húnv'nwv, s., the male of animals, man.

Hùnwetv, s., to smell, to scent.

Húte, home, house, a den.

Húten, at home.

Hutv'lkē, household.

Huyíretv, s., to stand.

Hvcátv, down, below.

$H_{v}$ 'cē, the tail.

$H_{v}$ 'è-catákv, red tailed hawk.

$\mathrm{Hv}^{\prime}$ cē-rafv'kso-rákko, slim tailed hawk.

Hv'cē-rafv'ksucē, sparrow hawk. $\mathrm{Hv}^{\prime}$ cē-sesteráhv, scorpion.

$H v^{\prime} c \bar{e}-t e ́ k v$, salamander, gopher. Hv'ce-teyákpv, forked tail hawk.

\section{$\mathrm{HVC}$}

$\mathrm{Hv}^{\prime}$ ckep-fúne, the leg bone.

Hvc'kewv, leg, shank.

Hvc'ko, the ear.

Hvc'ko-nókkē, ear-ache.

Hvc'ko-póheko, deat.

Hvc'ko-pókv, ear-lock.

Hvc'ko-tar'kv, ear-rirg.

Hvcókwv, fish-hawk.

Hv'fe, the thigh.

Hvfékpíkv, pantaloons.

Hv'fvpan, a thicket.

Hvfv téhkv, leggings.

Hv'ketv-pv'nkv, women's dance.

Hvkpv'tè, smaller, small.

Hvktésketv, s., to sneeze?

Hvkv'n-cellepétketv, v. c., s., to overset.

Hvkv'n-céllepetkv'ketv, p., to overset.

Hvkv'n-céllepótketv, s., to jump summersault.

Hvkv'n-cvllvpótkv'ketv， p., to jump summerset.

Hvlacv'lkē, robbers.

Hvlatepúecetv, s., v. c., cause to haul or draw.

Hulátetv, s., to draw, haul, to receive, hold.

Hvlatúecetv, s.v.c., to jerk, pull. Hvlatuecv'ketv, p., to pull, jerk or catch away.

Hvlháuwē, p., high:

Hvlhaúwan, highest.

Hvlháuwat, the highest.

Hvlkē, crawling.

$\mathrm{Hv}^{\prime} l \mathrm{ketv}$, s., to crawl.

Hvllecúsat, creeping.

Hvlpv'tv, alligator, crockodile.

Hvlv'kpotóke, lying on the face. Hvlv'tepúecetv, s., to draw as with a horse, etc.

Hvlvtétskvrēn, that you might take hold.

Hvlv'tetv, s., to hold, (see hvlat. etv. 


\section{HVL}

Hv'lwat-afópkē, hill side.

Hv'lwè, s., high, the heavens.

Hvlwécetv, v.c., to exalt, to hire, raise in the air.

Hv'lwehócē, a hireling.

Hv'lwetv, to be high.

Hv'lwē-tvlófv, kingdom of God, also of Heaven.

Hv'lwē - tvlófv - estv'lkē, angels, people of the kingdom.

Hv'lwe-tvlófv-estv'lke-kapetv'nē, arch-angel.

Hv'lwē-yohwíyet, cliff.

Hvmécetv, s., to go, or spread abroad.

Hvmecícet, all about, around.

Hvmecícetv, to go abroad, around.

Hvmecícetv, s., to spread abroad, compass, surround.

Hvmecícvres, it shall be universal.

Hv'mkan, the other, the other one.

$\mathrm{Hv}^{\prime}$ mkat, the whole, the other one.

Hv'mkē, one, a certain one, certain.

Hv'mken, one, certain, a certain one.

Hv'mkusē, one only.

$\mathrm{Hv}^{\prime} \mathrm{mkv}$, all about.

Hvmkv'nton, one by one.

Hv'mkvntvláken, one added on.

Hvmmáken, saying.

Hvmmáketv, s., to say.

$\mathrm{Hv}^{\prime}$ mmecátē, doing so, in this manner.

Hvmmécetv, s., to do so, in this manner.

Hvmméevtē, part., doing this.

Hvmúnt, so, thus.

Hv'mvcókwucē, humming bird.

Hv'mv-móketv, to hum.

Hvnv-célu, a lark.

\section{HVN}

Hvnvcv-félv, whirlwind, tempest. Hvnvwélv, linen.

Hv'po-háyetv, s., to camp, make or pitch tent.

$\mathrm{Hv}^{\prime}$ pon, camp, tent.

Hv'ppo, hill, heap, pile.

Hvréssê, the moun, moonlight.

Hvrēs'se-múcvsé, new moon.

Hvrēs'sē-pvléksē, full moon.

Hvrēs'sē-vlècv, lunatic.

Hvrēs'sē-vlícekv, lunatic.

Hv'rpē, the skin, hide or bark of

a tree.

Hvrv'nv yékcē, fish-hawk.

Hvrv'nwv, pigeon-hawk.

Hvsáf kē-enóketv, dropsy.

Hvs-aklätkv, West, where sun

falls down.

Hvsántkusē, very clean, holy.

$\mathrm{Hv}^{\prime} \mathrm{se}$, the sun.

Hv'sē-ahákē, sunflower, i. e., picture of the sun.

Hv'sē-aklátkv, sun down, West.

Hvsē-alikomv'lkv, monthly.

Hvsé-eskérkv, a watch, i. e., measure of the sun.

Hv'sē-eskérkv-rákko, a clock.

Hvse-hv'mke, next month.

Hvse--hv'mken, a month.

Hvsē-hvres'sē-tepóyet,the eclipse of the moon.

Hvsē-teyvpósket, eclipse of the sun.

Hvsē-vker'kucē, a minute.

Hvsē-vkérkv, an hour.

Hvs-neklécē, sun-burnt.

Hvsó, the sun's heat.

Hvsó-estákkē, prickly-heat.

Hvsos'sv, the East. sunrise.

Hvsoss'v-fv'tcv, from the East.

Hvsótvtes, the sun shines.

Hvsv'f kē, swollen.

Hvsvf'kē-enóketv, dropsy.

Hvsv'fkē-essíkv, liniment, opodeldoc. 


\section{HVS}

Hvsv'fketá, the mumps.

Hvsv'fketv, s., to swell, flesh a hide.

Hvsvfkv'ketv, p., to swell, flesh a hide.

Hvsvtécekvs, purification.

Hvsvtécetv, s., v. c., to cleanse, purify.

Hvsvtéckv, napkin, towel.

Hvsvtháketv, p., to be pure, clean.

Hvsvthákusē, rather, clean.

Hvsvthicvres, he will cleanse.

Hvsvtkat, being clean, holy.

Hrsv'tkè, s., clean, pure undefiled.

Hvsvt'tketv, s., to be clean, to purify.

Hvsv'tketv, very clean.

Hvsv'tkusē, a little clean.

Hvsvtkv'ketv, p., to be clean.

Hvtápket, descending, coming down.

Hvtápketv, s., to descend, come down.

Hvtápkóf, when he came down.

Hvtcátv, down, (i. e., down stream.)

$H_{v}$ 'tcē, brook, branch, creek.

Hv'tce-vkáckat, the mou'h of a stream.

Hv'tcucē, small brook, rivulet.

Hv'tē, now, just now, yet.

Hvtē-awóle, recent, just now.

Hvtecéskv, first in order, the beginning.

IIvtécetv, s., to whiten.

Hvtécv, a whiter, i. e., a fuller.

Hvtécvs, whiten it.

Hvtehácusē, foolish yet, lately deranged.

Hvtehákē, soon.

Hvtéhtvs, wait awhile.

Hvtéhtvsēn . after awhile.

Hvte-ísè, a little while ago.

\section{HVT}

Hvtekpíkv, pantaloons.

Hvte-máhets, very premature, very lately.

Hvtē-mómekv-múnkof, heretofore.

Hv'ten, early, as in the morning. Hvtèsé, son-in-law, or daughterin law.

Hvtetá, heretofore, before this.

Hvtetáwvn, beforehand, before.

Hvtetófv, by-and-by.

Hvtétusat, a little while,

Hvtéwv, the thigh or whole leg.

Hvtháke, white, the peace clan.

Hvtháketv, s., to be white.

Hvthícetv, s, v. c., make white, whiten.

Hvthiyv'ketv, p., to be white.

Hvthiyvtke, the morning, early.

Hvthv'kē, p., white.

Hvthv'kusè, p., a little white.

Hv'tke, s., white.

Hv'tkè-estépketv, chalk-line.

Hv'tke-káfkv, milk weed.

Hvtkéketv-lilv'kv, coach-whip, a whip.

Hv'tkë-tekfvn'kv, bald-eagle.

Hvttē, now, just now, yet.

Hv'ttecv's, make haste.

Hv'ttosé, a little whıle ago.

Hvttosv'ke, lately.

Hvtvlákat, more.

Hvtvlv'ken, more.

Hv'tvm, again, more, even.

Hvtrm-mó, again, more.

Hv'tvm-oh-máketv, s., to repeat. Hvtupécetv, s., to come down.

Hv'tvpecícetv, v. c., s., to let down.

Hvtv'pe-cícit, I letting him down.

Hvtv'pecicv'ketv, p., v. c., to let down.

Hvtv'pecícvs, let him down.

Hvtv'pketv, s., to come down, descend. 


\section{HVT}

Hv'twē, faded, pale.

Hv'twē-lánē, pale green.

\section{I.}

Isē, the same.

\section{I.}

Ká, for Hēnká, yes, very well, I will.

Kafákē, beat up, stirred together.

Kafáyetv, s., to beat ưpp liquid, etc.

Káfē, coffee.

Káfē-semfúlotkv, coffee mill.

Káfe-súkcv, coffee sack.

Káfetv, s., to row, paddle, to melt.

Káfē-vcv'nkv, coffee pot.

Káfken, melted, thawed out.

Káfketv, s., to thaw, melt itself.

Kafvnákv, fishing-worm.

Kahókvt, almost.

Kahónkv, almost.

Káketv, d., Liketv, s., Vpoketv, p., to sit down, to be, they were.

Kákkē a raven.

Kálfo, a logger-head, a small yellow catfish.

Kalkóra,(proper name) Golgotha.

Kálv]ēn, Galilee.

Kapetv'nē, captain, centurion.

Kápucē, vest, little coat, sack.

Kapúsko, ash-leach.

Kápv, a gown, coat.

Kápv-cápko, long coat.

Kapv'ket, apart, separate.

Kapv'ketv, s., to be apart, separated.

Kápvpóckv, hackberry.

Kápv-rákko, overcoat, big coat. Kapv-tókv, hat, bonnet, a crown. Kapvtókv-háyv, a hatter.

Kapvtókv-hiyáyvke, a crown, (shining hat).

\section{$\mathrm{KAP}$}

Kapvtóyē, May apple.

Kapvtóyetv, s., to cover the head.

Kapv-tóyv, a hat, bonnet.

Karóf kē, bald.

Karónetv, s., to carry on the shou!der, to bear.

Karónícetv, v. c., s., to cause to pack on the shoulder.

Karónv'ketv, p., to carry on the shoulder.

Karónvkúecetv, s., v.c., to cause to pack.

Káskè, combed, dressed off.

Kátcv, tiger, panther.

Kátē, a cat.

Kátetv, s., to scrape the inside of a vessel.

Katvpókv, hat, bonnet.

Katvpóyetv, s., to wear, to cover, Kaúkv'mpv, "cowcumber," cucumber.

Káwv, in the first place.

Káyetv, p., to lay eggs, to have young.

Kayv'kle, bow-legged.

Káyvranátskat, p., what you shall put on.

Ké, mulberry tree, mulberry.

Kecétketv, s., to bite off with the teeth.

Kéco, a mortar.

Kecv'pē, a pestle, pounder.

Kéfetv, s., to shovel up, take up by handfuls.

Ke-hv'sē, May, (i. e., mulberry month).

Kelásetv, s., to shell.

Kelécetv, s., to clip.

Keléhē, p., notched, broken out, gaped.

Kēlehécetv, to notch, frame.

Keléhusē, notched small.

Kemkécetv, s., to sound, as floor when walking on it. 


\section{KEM}

Kemkéketv, s., to ring, as an empty barrel.

Kéntè, dwarfish, scrubby.

Kentvkè, p., dwarfish, scrubby.

Kenvnv'lkē, Canaanites.

Kepálv, strawberries.

Kepáyv, the war clan?

Kerákko, fig, (i.e., the mulberry).

Kerákko-vpé, fig tree.

Keríckv, conscience.

Kérkekisá? why did you doubt?

Kérkekó, strange, unknown.

Kerkemáheko, uncertain.

Kérketv, p., to know.

Ker'kof, when he was betrayed, told on.

Kerkúecetv, v. c., confess, to explain, show, cause to know.

Kerkúeci-nómat, if I shall acknowledge.

Kerkúeckv, a witness.

Kerkúeckv-fvtcekón, false witness.

Ker'kusē, well known.

Kérkv, a witness, testimony sign.

Kérkvhén, plain, lucid.

Kerkv'ketv, p., to know, to believe.

Kérkvrē-tetáyē, sufficiently plain, evident; palpable.

Kērrá, doctor, learned, rabbi.

Kérreko, unknown, stranger.

Kérrepv'lkē, p., learners, disciples.

Ker'retv, knowledge.

Ker'retv, s., to know, to learn, discover.

Kerríkv, for I know.

Kerríyet, having known.

Ker'rv, s.,' a learner, disciple.

Kérrv'ketv, p., to know, be known.

Kerrv'lkē, p., learners, disciples. Kérsémenē, Gethsemene.

\section{KES}

Kestówv, red root, or, red shank.

Kétetv, s., to cut round, circumcise.

Ketkéwē, brindle.

$\mathrm{K} \bar{e}$-vpē, mulberry tree.

Keyákkv, crying-rabbit-hawk.

Kicá? do you say so?

Kicáketv, p., to say, to speak to.

Kicetv, s., to say or speak to, (i.e., to one person).

Kíckv, concerning.

Kihócetv, s., to blame.

Kihv'pvs, hold up.

Kíketv, to bite.

Kísē, hair of the head.

Kiyápetv, s., to raise up.

Kiyapíket, had risen up.

Kiyápket, raising up, lifting up.

Kiyápketv, s., to raise up, lift up.

Klétv, Crete, the island.

Kletv'lkè, the Cretans.

Ko, not, no, (a suffix to words.)

Kococúmpv, a star.

Kococúmpv-fekhúnnē, a fixed star.

Kococúmpv-sēnépkv, meteor.

Kocóknē, short.

Kocóknetv, s., to shorten.

Kócokníhcekos, cannot be shortened.

Kocóknusē, a little short, rather short.

Kocuncóketv, s., to shorten.

Kocuncókusē, very short.

Kófe, the groin, flank.

Kófetv, s., to hollow, dig out.

Kófkē, dug out.

Kófnetv, s., to thump, fillip with finger nail.

Kofóckv, mint, peppermint.

Kofóckv-rákko, horse mint.

Kofókē, churned, troubled by motion.

Kofóyetv, s., to churn, irritate by motion. 


\section{$\mathrm{KOH}$}

Kohá, cane, reeds.

Kóhá-hópkē, a weaver's sley or reed

Kohá-tv'skē, crossed reeds, mat.

Kóhmátskvs, p., you should not desire, or, don't think.

Kóhmvkēn, desiring.

Kók, because, not.

Kókkv, a swan.

Kókv, because, not.

Kolólokē, round.

Kolónetv, s., to cling with both hands and feet.

Kólretv, s., to dig.

Kolriyet, being dug.

Kólrv, a digger.

Komáketv, p., to wish, think, desire.

Komáket, desiring, wishing,thinking.

Kómat, desiring, thinking.

Komáto, desire, the wish or will. Komépetv, v. c., s., to desire, wish, think.

Kómet, desiring. thinking.

Kómetv, s., patience, to desire, wish, think, wonder at.

Komhóyetv, d., to wish, etc.

Kómís, s., I think.

Komófvn, when he thinks.

Komúksē, sour, alum.

Komúnken, before.

Kómvket, p., desiring, thinking.

Komv'ketv, p., to wish, think, desire.

Kónetv, s., to take from.

Konv'ketv, p., to take from.

Konvkhócē, unripe fruit.

Kópohúsē, small risings, bumps.

Kopúknícetv, s., to hump.

Koróyetv, s., to gargle.

Kosv táknv, comb of a cock.

Koténv? Mat. v : 26, for farthing. Kotv'ksē, bow-like, bending, bent.

\section{KOT}

Kotvksécetv, s., to make crooked, to bend.

Kowíke, partridge, quail.

Kowíkē-rákko, grouse, prairie hen.

Kowíkē-tokórēe, guinea hen.

Kúcē, the elbow.

Kulécetv, s., to light, to kindle, make shine.

Kuléhpv, lightning bug.

Kúlke, a candle, lamp, flame, blaze.

Kúlkē-hútē, lantern, candle, a light.

Kúlkē-sentáckv, snuffers.

Kúlkē-svhúerv, candlestick, lamp.

Kúlke-vcv'nkv, candle moulds.

Kulówv, glue, varnish, paste, putty.

Kulvpáken, seven.

Kúlwv, old time talk.

Kunáwv, beads.

Kunhè, crooked, bent.

Kunhecv'ke-táyē, pliable,yielding.

Kunhícetv, s., to bend, bow.

Kunhícv-yékceko, flexible.

Kúnnetv, s., to be maimed, bent.

Kúnte, arrow root, flour root.

Kúnu, skunk, polecat.

Kúphē, a hump.

Kús for Hekus, no, it is not.

Kusápē, impatient.

Kusapécetv, v. c., s., to make miserable.

Kusápkv, scarcity, want.

Kusápusit, being impatient.

Kúst, for Hekust, not, nothing, it is not.

Kusv'petv, s., to plead, to want, beseech.

Kusv'pkē, scarce, poor, indigent.

Kut! soho! alas! oh!

Kutē, a frog. 
$\mathrm{KVC}$

Kv'cetv, s., to break.

Kvcéyetv, p., to break.

$\mathrm{Kv}^{\prime}$ ckē, broken off, a mote.

Kvcképetv, s., to be broken.

$\mathrm{Kv}^{\prime}$ cket $\mathrm{v}$, p., to be broken.

Kvcó, a brier, blackberry.

Kvcó-húerv, blackberry bush.

Kvcó-húerv-yvlúnkv, blackberry root.

Kvcó-hv'lkv, dewberry.

Kvcó-hv'sē, June, (i.e.e, blackberry month).

Kvcó-lánē, green briar.

Kvcó-pvlv'knv, raspberry.

$\mathrm{Kv}$-es'sē, hair of the head.

Kv-es'sē-hv'tkē, gray hair.

$K v^{\prime} f k o$, a flea.

$\mathrm{Kv}$-fúne, the skull bone.

Kvhákkucē, a pin, or needle.

Kvhákkucē-svcakkéckv, pin or needle cushion.

$\mathrm{Kv}_{\mathrm{v}}$ hcátes, it is not broken, put asunder.

$\mathrm{K} v$-hómv, the forehead.

Kvhv'tkv, whiteheaded.

Kvlákcépetv, s., to break a bit out of anything.

Kvlákcowv, gall.

Kvláketv, s., to bite, gnaw.

Kvláksē, s., broken, with a piece out.

Kvláksécetv, s., to gap it, as edged tools.

Kvlaksépetv, s., to be broken or gapped.

Kvláksucē, picayune, (i. e., a little broken piece.)

$\mathrm{Kv}$ 'letv, s., to break off a piece.

Kvlhoyófvn, when it was broken.

Kvlkáyetv, p., to break, as of bread.

$\mathrm{Kv}^{\prime} \mathrm{lke}$, broken.

Kvlkétv, s., to break in pieces.

Kv'lkusē, a little piece of any thing.
KVL

$\mathrm{Kv}^{\prime}$ lpe , the brain.

$\mathrm{K} v^{\prime} l v$, white oak, acorn.

Kvlv'fetv, s., to plane, to shave as with drawing knife.

Kvlv'fke, pared, shaved.

Kvlv'pē, a white oak, or, over cup.

Kvlv'skv'kē, p., broken.

Kvn, euphonic termination.

Kvnáwv, a corner, an angle.

Kvncápat, underneath, below.

Kvncapé, luw, lowering.

Kvn-cápusē, lowly, rather low.

Kvn-oh-tvláko, ground peas.

Kvn cáte, Red Ground, (name of a town).

Kvn-cáyucē, a kind of ground lizzard.

Kvn-cvpákusat, the lowly, poor in spirit.

Kv'n-cvpákusè, p. . low, poor in spirit.

Kv'n-cvpē, low, meek.

Kv'n-cvpetv, s., to be low, humble.

Kvn-cvpáyē, meek, lowly.

Kvn-cvpúecetv,v.c., s., to abase, make low.

Kvn-cv'pv, below, (generally on earth).

Kvn cv'pv-fv'tcv, downwards.

$\mathrm{Kv}$-néksè, the head turned to one side.

$\mathrm{Kv}$-néksetv, s., to turn or toss the head to one side.

Kvn-hv'pe, fishing pole.

Kvn-kórke, the grave, ( $i . e_{0}$, a place dug out of the ground). INv-nókke, headache.

$\mathrm{Kv}$ - nókkē-heléswv; camphor,

(i.e., headache medicine).

Kvn-okkuce, fruit, falling untimely.

Kvnpókhucē, bunches of vegetables, hyssop. 


\section{KVN}

Kvn-sátkv, a mark on the ground, twenty-five cents.

Kvn-súfke, a hole dug in the ground, cellar.

Kvnáwv, a corner, an angle.

Kvpáketv, s., to separate from, to depart.

Kvpakícetv, s., to forgive, cause to depart.

Kvpē, lye, (i.e., produced from ashes).

Kvpē-escáf kv, a leach, lye hopper, strained.

Kvpéletv, s., to pry, (as with a hand spike).

Kvpérv, the right side, the right. Kvpícetv, v. c., S., to forgive, cause to separate, to give.

Kvpicv'ketv, v. c.. p., to forgive, cause to separate.

Kvpiyecícetv, v. c., s., to separate, bereave, cause to part.

Kvpíyetv, s., to separate, forgive.

Kv'poloyē, May apple.

Kvpv'ken, from.

Kvpv'ket, apart, separate, forgiving.

Kvpv'ketv, s., apart, to depart, part from at will.

Kvpvpásketv, s., to rattle or crack, (as in breaking sticks).

Kvprpáskv, spice wood.

Kvpv'pvsécetv, s., v. c., to crack as in breaking sticks.

Kvrkápv, dry.

Kvr'pē, dry.

Kvrpécetv, s, to dry.

Kvr'petv, s., to dry, be dry.

Kvsasúcē, a pin.

Kvsatúecetv, s., to strike fire.

Kvsáyetv, s., to scribble, pretend to write.

Kvskv'nv, left-handed, to the left. Kvsóhē, grain in the milk.

\section{KVS}

Kvsókē, grain in the milk.

Kvstémkv, cold, (a Kvncate word.)

Kvsv'mkekátes, suffered.

Kvsv'mkvn, praise.

Kvsv'mrē, thin, clear, liquid.

Kvsv'mrécetv, v. c., s., to thin, make clear.

Kvsv'mrusē, a little thin, clear, (as paste.)

Kvsv'ppē,cold,inclement weather Kvsv'ppē-aklópetv, cold bath, chill.

Kvav'ppetá, very cold.

Kvsv'ppetv, s., to be cold.

Kvsv'ppē-tvlofécetv, s., to freeze.

Kvsv'ppetvts, it is cold.

Kv'svsv, katy-did.

Kv tákınéletv, s., to turn back.

Kvtóhwv, the nut of the coffee or locust tree.

Kvtohwv'pē, coffee tree, locust tree.

Kvtv'rpv-pv'pkv, hazel nut, Kvwáhpet, rising up.

Kvwákucè, a wild cat, catemount. Kvwapétskēs, you rising up.

Kvwápetv, s., to rise up, to lift. Kvwápketv, p., to rise up, be exalted.

Kvwékle, bow-legged, legs far apart.

Kvyúknetv, s., to kick up the heels.

Kvyúnkv'ketv, p., to kick up the heels.

Kvyv'kle, bow-legged.

\section{L.}

Same as in English.

Láhsetv, s., to taste.

Láhsot, when he had tasted.

Lakisátskvs, 2nd per. p., accuse - not falsely. 


\section{LAK}

Lákset, it is a lie.

Láksetv, s., to lie, tell lies, accuse faisely.

Laksv'ketv, p., to lie, tell lies.

Láksv, a liar.

Lalúnkv, the root, letter of alphabet.

Lalúnkv-cáte, a beet, or raddish.

Lánē, yellow, green, dun, verdant.

Lánē-awótkv, bile, green vomit.

Lánē-múnkv, evergreen.

Láne-ómè, copper color, drab.

Lane-pápv, lettuce.

Lapútkè, straight.

Lasécetv, V. c., s., to make lick, taste.

Lásetv, s., to taste, to lick.

Lasv'ketv, p., to lick, taste.

Latárē, cut up, butchered.

Latarécetv, s., to cut up, butcher.

Lataréskv, cut up, butchered.

Látkē, fallen.

Látketv, s., to fall down.

Latkv'ketv, p., to fall down.

Latláketv, s., to gallop.

Láukáten, depth, overflowing.

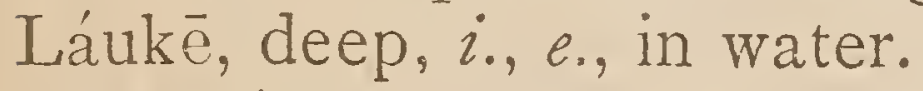

Lauketá, very deep.

Láuketv, s., to overflow, to flood, be deep.

Láuko, hunger, to be hungry.

Láuwecécetv, v. c., s., to deepen.

Lauwétv, s., to dig, till the soil.

Láuwetv, s., to be hungry, to fast.

Lauwikekos, shall not overflow.

Lè'cē, a boil, or sore, abcess.

Lècè-kákv, small-pox.

Léce-kákv-sentv'cketv, s., to vaccinate.

Lecéskv, the heel.

L'ecétv, s., to kill.

L'ecv, beneath, underneath.

L'e-étskv, the big toe, $i$. e., the mother toe.

\section{$\mathrm{LEH}$}

Lèháyv-tvpéksē, a pot.

Lekáfaks, thrown down.

Lékfetv, s., to take down, destroy.

Lekafléhcit, I will pull down.

Lekáhfit, I am able to destroy.

Lékhē, lukewarm, tepid.

Lekhícetv, S., v. c., to make luke warm.

Lekhówē, p. sores, boils, ulcers. Lékhusè, tepid, luke-warm.

I,ekónthusē, calm, warm.

Lekúcwè, dirty, filthy.

Lekúthè, s., calm, still, warm.

Lekuthv'ke, p., calm, still.

Lekv'pv, blazes, flames.

Lékwè, running sore, a boil.

Lékwē, rotten, décayed.

Lekwécetv, v. c., s., to rot, cause to decay.

Lékwe-elécv, mortification.

Lékwe-essíkv, salve.

Lekwekó, sound.

Lékwē-ómē, musty, rotten.

Lékivē-pápv an eating cancer.

Lékwetr, s., to rot, decay.

Lékwusè, rather sore.

Lémetv, s., to pluck, pull off hair, feathers, etc.

Lémkè, bald, deprived of hair or feathers.

Lemv'ketv, p., to pluck up, pull off.

I.entáppetv, s., to stumble, blunder.

Lentáppúecetv, v.c., s., to make stumble.

Leócv, a pot, or oven of any kind.

Leócv-orv'nkv, an oven lid, pot lid.

Leócv-tvpéksē, an oven, flat oven.

Lepépeté, glistening.

Lepépetúsè, little glistening. 


\section{LEP}

Léppē, glimmer.

Léppv, a leper.

Léppvsē, leprosy.

Lepv'kfè, slimy, ropy, (like phlegm.)

Lepv'kfv, slime, viscous matter. Les'kan, old, (as of clothes, sacks, bags, etc.)

Léskè, old, (as of clothing, house, fence, bones, etc )

Léslekan, old, as of clothes, etc. Lètécícetv, v.c., s., to make run. Letéfketv, s., to drop the hair.

Letéf $\mathrm{kv}$, any thing shedding hair, as a wolf, dog, etc.

Letéketv, s., to trot along.

Letiketv, s., to have run.

Létkē-héra, a pacer, or a good walker.

Létkē-héretv, s., to pace, or walk well.

Létketv, s., Tokórketv, d., Pefátketv, p., to run.

Létkv, a runner, racer.

I,etv'kvnécv, a blister bug.

Lè-wesákv, the smaller toes.

Lícetv, s., v. c., Káyetv, d., Apóyetv, p., to set, settle, to place a thing.

Likè, sitting down.

Likē-múnken, long ago.

Líketv, an abode, residence.

Líketv, s., Káketv, d., Vpóketv, p., to sit.

Likíyatéh, dwelling.

Likv'cukat, about.

Likv cúken, in, witkin.

Locá, a turtle, terrepin, tortoise. Locá-húehkv, the crying turtle.

Lócá-rákko, the large turtle.

Locá-saúkv, the dancing rattle of terrepin shells.

Locá-tokátskē, a terrapin.

Locá-yékcv, snapping turtle.

\section{LOK}

Lokáketv, p., to swallow, devour.

Lókcē, ripe, matured, as fruit.

Lókcetv, s., to ripen, mature.

Lokcícetv, v. c., S., to raise, ripen, cultivate.

Lokcíckv, ripened by cultivation.

Lókcusē, a little ripe.

Lókcus-máheko, not very ripe.

Lókc $v$, fruit, acorns.

Lokcv'kē, p., ripe.

Lókcvpè, acorn tree, black oak, oak.

Lókcvpē-hákv, oaken.

Lókcvpé-hv'rpē, oak bark.

Lóketv, s., to devour, eat, swallow.

Lokotícetv, s., to gorge.

Lókv, devourer, glutton.

Lopícetv, s., to do good, do a favor, be profitable.

Lopíckv, Lopicákē, gain, profit.

Lopóntskusát, the least.

Lopóntskusē, p., least, very small.

Lopotecícetv, v. c., s., to make smaller.

Lopótkē, small, powdered, beaten, mashed.

Lopótetv, s., to grind to powder. Lopvkúecetv, s., to persuade.

Lotókkè, exhausted.

Lotókketv, s., to faint under exertion or fright.

Lóyetv, s., to fill.

Lúcuwv, an Indian jug.

Lúeyetv, s., to hoe.

Lúmhè, lying prostrate.

Lúmhetv, to lie down.

Lumhícetv, v. c., s., to make lie down.

Lupákv, slippery elm, flattery.

Lúpē, the liver.

Lúpē-cápko-hopvnkē, inflammation of spleen. 


\section{LUP}

Lúpē-cápko, the spleen, melt.

Lúpe-hopv'nkē, inflammation of the liver.

Lusv'kkē, split off, slightly split.

Luwácetv, v. c., to make limber, to $\tan$.

Luwakè, limber, nimble, soft, tender.

Luwóckē, s., soft, tender.

Luwóckusē, s., very soft.

Luwóclokē, p., tender-hearted; soft.

Luwoclókusē, very soft.

Lúyetv, s., to hoe.

Lvcē, a limb or branch of a tree.

Lvcē-cuecóhē, frozen limbs.

Lv'cpē, damp, wet.

Lvcpécetv, s., v. c., to dampen, wet.

Lvcpetá, very wet.

Lv'cpetv, wet, damp.

Lv'fetv, s., to cut with a knife.

Lv'fkè, a gash, a cut.

Lvkáhē, speckled, red color.

Lv'khē, a gap, notch.

$\mathrm{Lv}^{\prime} \mathrm{ksv}$, the hoof of animals.

Lv'mhe, an eagle.

Lvpécē, quickly, anon.

Lvpécetv, s., to hurry, make haste.

Lvpecícetv, v. c., s., to hasten, (i. e., others).

Lv'pkē, haste, lightly, in a hurry, quick.

Lvpkusátē, instantly, soon.

Lv'pkusē, immediately, straightway.

Lv'pkusen, instantly, quickly.

Lv'plvpécetv, s., to lap.

Lvpúlvpu, a small worm.

Lvpúntkē, straight.

Lvpúntkusē, very straight, perpendicular.

\section{LVP}

Lvpútke, straight, upright.

Lvpútketv, p., to rear up like a horse.

Lvputécetv, v. c., s., rear up, to straighten up.

Lvpútetv, s., lift up, to straighten up.

Lv'pv, a snail.

Lvpv'tke, a dell, in the woods, shore.

Lvsáfkē, cut or broken off slenderly.

Lvsóf ketv, s., to cut off slenderly. Lv'stē, black.

Lvstécetv, v. c., S., to blacken, to dirty.

Lv'stetv, s., to be black.

Lv'stetv, very black.

Lvtcéksēe, low sr part of legs, not erect.

\section{M.}

Same as in English.

$\mathrm{M}$, often contracted for $\mathrm{Em}$ or $\mathrm{Mv}$, he, she, it.

$\mathrm{Ma}$, or $\mathrm{Mv}$, that, them, there:

Macr'nis, for Em-acv'nis, I encouraged, or, exhorted them.

Mafástetv, s., to attend to that.

Mafulótetv, s., to encompass, surround.

Máfulotv'ketv, p., to encompass, surround.

Mafv'ckē, his, her, or its happiness.

$\mathrm{Mah}^{\prime}$, that.

Màhē, very, joined to an adjective puts it in superlative degree.

Mahécetv, s., to build up, make good, nourish.

Mahecv'ketv, p., to build up, raise up, nourish.

Máhekv, oft times.

Máhen, about, very much. 


\section{$\mathrm{M} \Lambda \mathrm{H}$}

Maherícetv, s., to mend, darn, build, fix.

Maheríckv, mended, fixed garnished.

Máhetv, s., to grow tall, (as a person).

Máhē-yv'mkē, tipsy, drunken.

Máhhan, real, genuine.

Mahlústetv, s., to like, approve.

Mahlvpv'tetv, s., to comfort.

Mahlvpv'tketv, p., to comfort.

Mahlvpv'tketvn, comfort.

Mahmícetv, s., to raise.

Mahóckēe, fragments.

Mahóks, not grown.

Maholócetv, s., to envy.

Maholóckv, envy.

Mahomáhtetv, s., to guide.

Mahomáhtv, a guide.

Mahonkv'tkv, number.

Mahonkv'tkv - cakkák - sekó, le. gion.

Mahórkv, seam.

Mahórv, seamster, seamstress.

Máhusat, even as, that very, much.

Máhusē, very much.

Máhvkau, even there, specially, much more.

Máhvtes, (from Máhetv) it is very.

Mahyúmecícetv, v. c., s., to intoxicate.

Mahyum'kē, tipsy, intoxicated.

Mahyúnkē, faint.

Mahyúnket, fainting.

Mahyúnketv, s., to faint.

Mahyúnkusé, languid, fainty.

Makánē, venereal disease.

Máket, saying.

Máketv, s., to say, allege, affirm. Mákvkē, is reported.

Malumhícetv, s., to cobble, patch. Mámetv, s., to pick, to gather, reap.

\section{MAM}

Mamhóyetv, d., to pick, to gather, reap.

Mamv'ketv, p., to pick, to gather, reap.

M ıómes, it is like it.

Maómet, it is like.

Maómusē, for so much.

Mapéttē, its shade.

Mapohícetv, s., to listen, be obedient.

Mapohicv'keko, a disbeliever, disobedient.

Ma-pvlwv, a part, remainder.

Márv, a war tittle, (as Colonel, Major).

Marvpótetv, s., to comfort.

Marvpótkē, serene, comforted.

Marvpótkvrē, he will be comforted.

Márvpv'kekvs, s., be comforted.

Márvpvtetícvks, p., be ye comforted.

Márvpv'tketv, s., to be comforted.

Masúmketv, s., to guess.

Mata, the same.

Matvpómé, likewise, the same, in like manner.

Matvpomécetv, s., to do likewise.

Matvpomécícetv, s., v. c., to cause to do likewise, in like manner.

Matvpómusē, even so, likewise.

Matvpómvs, alike.

Mátvwv, the same.

Mawéh, also.

Maweténetv, s., to hold down.

Mayák-hv'mkē, rapid, rash.

Mayák-hv'mketv, s., to be rash, rapid, hasty.

Mayetv, s., to fan.

Mayetv, a fan.

Méce-múnks, still, still doing.

Mecev'nto, was accustomed to do.

Mécetv, s., to do. 


\section{$\mathrm{MEH}$}

Meháketv, s., to wait for, endure, have patience.

Mehénwē, truly, doubtless.

Mehen-wécetv, s., to affirm.

Mehénweko, not true, false.

Mehénwetá, very true, candid.

Mehénwetv, s., to be true, true.

Mehénwusán, truly.

Mehénwusē, very true, surely, really.

Mehénwv, truth, fact.

Mehénwvn, verily, truly.

Mehénwvts, it is true.

Mehíwv, daughter-in-law.

Mehócetv, pass. s., to be done.

Mékketv - tvlófv, kingdom of heaven.

Mékketvt, the kingdom.

Mékko, the king, chief, ruler.

Mekko-cúken, in the room of, the reign.

Mekko-cúketv, s., to reign.

Mékko-enákè, regal, royal.

Mékko-hókte, the queen.

Mekkv'lkē-náké, royal.

Mekusápēe, prayerful, pious.

Mekusápv, a praying person, Christian.

Mekusápv-aháyv, a hypocrite.

Mekusápv-em-afv'stetv, sacrament.

Mekusápv-hérat, a saint, good Christian.

Mekusápv'ketv, p., to worship, pray to.

Mekusapv'lkē, p., praying persons, Christians

Mekusápv-wíketv, s., to aposta tise.

Mekusv'petv, s., to pray, to worship.

Mekusv'pkv, religion, prayer.

Mekusv'pkv-cúko, church-house, the church.
MEK

Mekusv'pkv-vhákē, heresy.

Mekusvpv'tcetv, s., v. c., to wor. ship, to pray.

Mekvléssē, England.

Mek lesss'lke, the English.

Meláuketv, s。, to famish, fast.

Mélletv, s., to decree, appoint, predestinate.

Mélletv, appointment, predestination.

Melly'ketv, p.,to appoint, decree, predestinate.

Mellv'kvte, ordinance, decree,

Mellvtéhkvn, appointed, predestinated.

Melóhletv, s., to waver, to roll, ripple, to be in doubt.

Melohlícetv, v. c., to roll, toss, arose.

Melóhlv, a ripple, or wave.

Men-héretv, s., to delight.

Mérkv, mercy, pity, compassion. Mermáyetv, s., to flutter.

Merócketv, s., to drop suddenly. Meróhketv, s., to wave.

Merrakáté, merciful.

Mer'reta, mercy, pity, compassion.

Mérretv, s., to pity, have mercy, to bless.

Merrv'ketv, p., to pity, have mercy. bless.

Merv'lv-hónketv, p., to shake as leaves, quiver.

Merv'rákety, S., to shake as leaves.

Mésetētv, s., to wink.

Mesísa, Messiah.

Méskē, sweat, summer, and hence a year.

Méskē-hv'mken, next summer.

Mésketv, s., to sweat.

Méskē-v'nkē, last summer.

Méskvl-v'pé, a species of oak. 


\section{MES}

Meskv'lwv, chestnut oak, water oak.

Mesméyetv, s., to wink often.

M-etenráwv, in the midst of them.

Metetáketv, s., to be ready.

Metetakúecetv, v. c., s., to make ready, prepare.

Meteyofícetv, s., to close in place of.

Metóhkv'letv, class.

Metóhtv'retv, s., to lay up the fence.

Metvlhv'mkē, a citizen.

Meyúksv, its end, the end of it.

Meyúksv-sekó, eternity, no end.

Miloméketv, s., to quiver.

Mímv, as, there.

Mimvmit, even as.

Mímvn, there.

Mímvt, there, was there, or it was there.

Mín, there, rather.

Min-hónrkv, hope.

Mit, it.

Mit-en-hēet, it were better.

Móhmen, and, and then.

Móhmes-kómokon, accident.

Móhmet, and, then.

Móhmet-hákis, it happens.

Móhmvtē-vtékat, since.

Móhtvkhákv, his yoke.

Móhtvkhákv-em-ésetv, s., to unyoke.

Móhtvkháyetv, s., to yoke.

Mókē, dust, soil, anything, blown about.

Mokmérkē, its tassel.

Molátv, mulatto, creole.

Molatv'lké, p., mulatto people, creoles.

Momá? is it so? why then?

Momákatatátes, it was not so, was not.

\section{MOM}

Momáketv, p., to do, make it so. Móman-vpáken, immediately. Mómat, it is that, that, it is done. Momaten, whereupon.

Mómē, it is, yes.

Momécetv, s., to do, act, perform. Mómecv'ketv, p., to do, act, per form.

Móme-estómis, nevertheless.

Mómekon-ómat, lest, if not so.

Mómekv, wherefore, therefore.

Mómekvs, s., amen, let it be so.

Mómemvts, modern, it was so.

Mómen, and.

Mómen-ócof, at times.

Mómen-ómat. otherwise, if so.

Momépekvs, s., amen, let it be so.

Mómēs, It is so, yes, it might be so.

Mómes-kómis, yes, I think so.

Mómēstomis, although, notwithstanding.

Mómet, for, and, also.

Móme-tás, it can be done.

Móme-tétas, necessary, it must be.

Móme-tetáyē, possibly, is possible.

Móme-tetayen-ómat, provided it can be done.

Mómetv, s., to be so, to be done, it is so.

Móme-wítes, probably, perhaps.

Mómis, but, though, although.

Mómísem, even so, so-so.

Mómískomē, patient, enduring.

Mómis-kómetv, s., to be patiens, to endure.

Mómis-ómes, perhaps so.

Mómof, then, while, when.

Momóftan, then.

Momófvn, during.

Mómose, then, for the present, this is all. 


\section{MOM}

Mómusen, it is so, it will do.

Momv'ketv, p., to be so, to be done.

Mómvn-ócof, at times.

Mómvnt-ómet, accustomed, was wont.

Momvrános, almost, about to be.

Mómvrē-héren, as well as.

Mómvrēs, it shall or will be so.

Mómv'r-haks? when shall it be?

Mómvtē, was done.

Momvtékat, so great, so much.

Monáyetv, s., to tell, inform, promise him.

Mónem-melhóyetv, s., to appoint.

Mónkat, neither, or, nor.

Mónkon, not so.

Mónkon-ómat, if not, except, lest.

Mónkos, no, it is not so.

Mónko-táyusen, by no means.

Mónks, (contraction of Monkos) no, etc.

Mónkvtós, it is not so.

Mónt, again, in like manner.

Mónt-ómen, and again, in so much.

Mónt-ómis, yet again, yet.

Mopunv'kv, (from em and opunvkv) his word, talk.

Morécetv, v. c., s., to make boil, to try.

Mióretv. s., to boil, to fry.

Mórkē, boiled.

Mórketv, p., to boil.

Morv-herv'kv, differences.

Morv-pánkusēe, calm.

Móshon-kerremáhekot, obscure.

Moskómekot, not regarding, profligate, despising.

Moskómetv, s., to regard.

Mosúletv, s., to shut the eyes.

Múcv, now, at the present time.

Múcv-nérē, to-night.

\section{MUC}

Múcv-néttv, to-day.

Múcvsat, new, it is new.

Mùcvsē, new.

Mucvsé-cekvs, make it new.

Mucvsécetv, s., to renew, make new.

Mucvsv'kē, (p. of Mucvse) new.

Mucrsv'ketv, p., to make new, be renewed.

Mucvtán, now, just now.

Mucv-vtékat, henceforth.

Múnkat, or.

Múnkekvs, let it be, be forever.

Múnken, until.

Múnket, enduring.

Múnketv, s., to be always, endure.

Múnkv, therefore.

Munkv'hkvn, therefore.

Múnkvres, ever, forever, it will ever be.

Múntale, excellent.

Muntalécetv, v. c., s., to excel, conquer.

Muntáletv, s., to conquer, excel. Mvntálv, a conqueror.

Muntálvt, excelling, prevailing.

Muntómán, nevertheless.

Mutésv, a jug, jar.

Mútetv, s., to cut blunt, to bruise.

Mútkē, s., blunt, cut off.

Mútkè-crtókmē, blunt.

Mutmv'ké, p., blunt, cut off.

$\mathrm{Mv}$, or $\mathrm{Ma}$, that, then, who.

Mv-áyetv, thither.

Mvcáhnetv, s., to command, encourage, exhort.

Mvcéwetv, s., to stay, loiter.

Mvcv'netv, s., to pour in.

Mvcrnéyetv, s., to gaze.

Mvfv'letv, s., to fling up at anything.

Mvfv'stetv, his employment, business. 


\section{$\mathrm{MVH}$}

Mvhákv, the law, the school.

Mvhákv-cúko, school-house.

Mvhákekv, for he taught them.

Mvháyetv, s., to teach.

Mvháyv, teacher.

Mvherícetv, s., to mend, make good.

Mvhórkv, a seam.

Mvkcáukv, cream.

Mvkcáwetv, p., to skim.

Mvkeláketv, s., to gnaw at.

Mvkerkúecetv, s.,to mark, brand.

Mvker'rē, knavish, deceitful.

Mvker'retv, wiles, guile, deception, deceit.

Mvker'retv, s., to deceive, entice.

Mvker'ríckv, his or her thoughts.

Mvkérrv, deceiver.

Mvkerrv'lkē, deceivers.

Mvketéken, at the same time, during, while.

Mrketékof, at that time.

Mvketéuks, exactly.

Mvkvtéhkusē, prime.

Mv-lícetv, s., to mend, (as cloth.)

Mvlíketv, a clan, dwelling together.

Mv-líkv, a patch.

Mrlóstē, anxious.

Mvlóstetv, p., to desire, be anxious.

Mvlóstvkēt, desiring.

Mvlostv'ke:v, s,, to desire, be anxious.

Mvlumhicetv, s., to button, patch.

Mvlúmhv, a button, a patch.

Mvmáhusat, real, very true.

Mvmomv'kē-tárēs, it shall be tolerable.

Mvn, there.

Mvnéttat, being young.

Mvnéttē, young.

Mvnéttusēe, very young.

Mvnéttusof, from the youth.

\section{MVN}

Mvnettv'kē,p., young.

Mvnettv'lkē, p. young persons.

Mv-néttv-rnáhusat, the self-same day.

Mvnícetv, s., to abet, aid, help.

Mvnícv, a benefactor, helper.

Mv'ntē, Monday.

Mv'ntē-enhiyv'tkē, Tuesday.

Mvnv'ckē, dextrous, well trained.

Mvnvcketá, very dexterous.

Mvnvttécetv, s., to hinder.

Mvnvttépetv, s., to escape.

Mvnv'ttetv, s., to escape.

'M'v'pe, the handle, the helve, stalk, stem.

'Mvpéttē, its shade.

M v p v k v'lkēe, representatives, rulers.

Mvrahkúecetv, s., to disfigure, alter, change.

Mvráhkv, s.. different parts, sorts.

Mvráhkv-háyetv, s., to change, make a change.

Mvsáyetv, s., to whet.

Mvséhetv, s., to forbid.

Mv'sle, muslin.

Mv'sta, mustard.

Mv'sta-enérkv, mustard-seed.

Mvsumketv, s., to guess.

Mvtán, the same.

Mvtát, it is that.

Mv'tis-estónkos, agreeable.

Mvtís-hérs, meddling.

Mvttecícetv, v. c., to deliver from evil.

Mvtó, thank you, $\left(i . e_{.,}\right)$that's the thing.

Mv'tte, a fault.

Mv'ttēkát, not guilty, innocent.

Mv'ttekós, innocent, not guilty.

Mv'tletícetv, s., v. c., to cause to offend, to $\sin$.

Mv'ttetós, have offended, I a sinner. 


\section{MVT}

Mv'ttetv, s., to offend, ro $\sin$. Mvtúlkv, border.

Mv-tvkhv'kē-ocetv, to put beside.

Mv-tv'lken, that only.

Mv-tvlófv-líketv, s., to inhabit.

\section{N.}

Same as in English.

Náftelem, the town of Naftalim.

Nahv'pè, a splinter.

Nahv'petv, s., to be splintered.

Nahvpúecetv, s., v. c., to cause to splinter.

Nak or Nake, a thing.

Nakcelákv, business, utensils, deeds.

Nakcelákv-sehonéckv, a miracle.

Nakcélkv, film, scale.

Nakcókv, paper, a book, letter.

Nakcókv-enhécv, a pupil.

Nakcókv - enhótci - sēko, blankbook.

Nakcókv-eskerkúeckv, account book.

Nakcókv-es'sē, leaf of a book.

Nakcókv-esyvhíketv, hymn or song book.

Nakcókv-hécv-empv'lsē, school fellow.

Nakcókv-múcvsat, New Testament.

Nakcókv-mvháyv, teacher, missionary.

Nakcókỵ-mvhayv'lkē, teachers, missionaries.

Nacókv-Rákko, the Bible.

Nakcókv-setempóhetv,catechism.

Nak, something, anything.

Nakcókv-vhecícv, librarian.

Náke or Nak, a thing, (p., Nanv'kē.)

Nákē? what is it?

Nákē-celákv, deeds, duty.

\section{NAK}

Nákē-celáyetv, s., to engage, to do.

Nákē-celayv'ketv, p., to engage, to do.

Nákē-éhkat, the mystery.

Nákè-ēnkvpv'ketv, self-denial.

Nákē-enlopíhócē, benefit.

Nakē-estvpénkvlécv, a robber.

Nákē-eyácetv, s., to want something.

Nákē-lókcocè, vegetables.

Nak-émetv, a gift.

Nak-emkv, a gift.

Náken, what.

Nak-encákè, penurious.

Nak-encáket, being penurious.

Naken-oká? what does it mean?

Nakè-ocakè, substance.

Nak-eshákv, a tool, instrument.

Nak-eskérretv, a sign.

Nak-ésketv, drinks, something to drink.

Nak-es'sekv, lieutenant.

Nak-estvpénkvlécv, a robber.

Naket' $\bar{e}$ ? What is it?

Náketv, what is to be, to mean.

Nákē-vhákēe, idols, pictures.

Nákē-vtelćkv, harvest.

Nak-háyekot, mocked, made light of.

Nak-háyetv, s., to mock, ridicule. Nak-háyv, maker of something.

Nakhēcihócat, a vision.

Nak-hayv'ketv, p., to mock, ridicule.

Nak-hótcē, a letter, book, paper.

Nak-hv'rpe-catécv, a tanner.

Nak-hv'tkē-tvkócv, linen.

Nakkérretv, prudence.

Nak-lánucè, salad.

Nak-léskē, ragged, worn out.

Nak-léskv, rags.

Naklíkē, lump.

Nak-ócē, rich, having property. 


\section{NAK}

Nak-ócetv, to have anything.

Nak-óckv, domestic business.

Nak-okétv, s., to gossip, rattle.

Nak-omv'lkv-ohháyvté, created all things.

Nakonv'kv, a tale.

Nak-pálv, borrower.

Nak-sésketv, drinks.

Nak-séstem-vlesképkv, ousness.

Nak-sóh-apóyv, a shelf.

Nak-stenceláye-óketv, S., to accuse.

Nak-sulécet $v$, treason.

Nak-svkoskv, washing-tub.

Nak-tárv, a knitter.

Nak-tóko, nothing.

Nákuce, little things, goods.

Nákucē-hómpetv, groceries.

Nak-vcákē, precious things.

Nak-vfástv, a steward.

Nakv'ftēn, assembled.

Nakv'ftetv, s., to assemble.

Nakv'ftetv-cúko, council-house, synagogue.

Nak.vfv'stetv, business, political.

Nak-vfv'ste-máheks, neglectful.

Nak-vhákē, an idol, picture.

Nak-vháke-v vástv, idolater.

Nakv'ikè, kin, kinfolks.

Nak v'cetv, clothes, garments.

Nak-vtēhkv, work-bag, vessel.

Nak-wikv-v'lkan, market.

Nak-wíyetv, a gift, offering.

Nak-wíyucē, a pedlar.

Nak-wíyv, a trader.

Nalokfúnwv, the beak, bill.

Nanópetv, s., to pick about, to feed.

Nanópkv, pasture, feed.

Nanópv, a feeder.

Nanv'comet, harm.

Nanv'h-okícekot, speak evil of none.
NAN

Nanv'kē, (p. of Nákē) things.

Nanv'k-óketv, idle tales, evil speaking.

Naorícē, troublesome, plaguey.

Naroícetv, S., V. c., to trouble, plague.

Naoríckv, trouble, cares.

Naórkē, pernicious, sinful, guilty.

Naórkepúecetv, s., to tempt, make sin.

Naórketv, sin, wickedness.

Naórketv, s., to sin, do wrong.

Naóıketv-emvnícetv, s., to bribe, to help in sin.

Naórketv-enhvsv'tketv, s., to sanctify, sanctification.

Naórkucē, a cockroach, little pest.

Naórkv, a sinner, wicked person, a roach.

Naorkv'ketv, p., to sin, act wickedly, be troubled.

Naorv'ketv, s., to be troubled, to sin, do wrong.

Natárv, a dirt dobber.

Natv'lkè, naked.

Natv'rkv, an earthen pot.

Nehá, oil, butter, fat of any kind.

Nehacv'kvtēn, fatted.

Nehe, fat, oily.

Nehēcécetv, s., to garnish, ornament.

Nehēcēcv'ketv, r., to garnish, ornament.

Nehéckv, dress.

Nekáttetv, s., to bow the head.

Nekéyetv, s., to move, to shake.

Nekéyetv, the shaking, earthquake.

Nekēyíckv, power, might.

Nekéyv, earthquake.

Nékrē, a burn.

Nékrēn, is burning.

Nékret, burnt, being burnt.

Nekrétv, s., to burn, consume. 


\section{NEK}

Nekrícetv, v. c., s., to burn, cause to burn.

Nen'nē. a path, a way, road.

Nènne-cv'ppv, half way.

Nen'ne-cv'ppv háco, crazy or colonel, half way.

Nénnē-spáskv, a wagon road.

Nénnē-rákko, big road.

Nennē-témpē, by the way.

Nèrē, night.

Nēreísē, last night, all night.

Nēēe-kápv tókv, night-cap.

Nērē-nvrkv'pv, midnight.

Nëre-v'tcetv, night clothes.

Nérkucē, corn-grits, hominy.

Ner'kv, seed, grain, kernels.

Nérkv-en-césketv,threshing-floor.

Nerréketv. s., to be propped up.

Nésetv, s., to buy, purchase, redeem.

Néskvcúko, trading house, store.

Nësv, merchant, buyer, redeemer.

Netté, late in the day or night.

Néttv, a day.

Néttv-cáko, sacred day, the Sabbath.

Néttv-cáko-cúsē, Saturday, (i.e., little brother of Sabbath).

Néttv-cáko-rákko, Sabbath, Christmas.

Néttv-cákucē, the week, the Sabbath.

Nettv-cákucē-en-nvrkr'pv, Wednesday.

Nettv-cákucē-ecúse, Saturday.

Nettv-cákucē-omv'lkvn, weekly.

Nettv-cákucē-v'nke, last week.

Nettv-espóké, the last day.

Néttv-nvrkvpv, mid-day, noon.

Néttv-ócen, the future.

Nettv-óretv, the future state.

Néttv-vcáka, the Sabbath, holy day.

Néttv-yvmáhketv, s., to idle, (i.e., waste the day).

\section{NOC}

Nócē, silk weed.

Nóckv, handkerchief.

Nóckv-rákko, a shawl.

Nók-cáketv, s., to strangle.

Nók-cakvketv, p., to strangle.

Nók cēpéláketv, p., to choke, to strangle.

Nok-cêpéletv, s., to choke, to strangle.

Nók-cvkákv, gills of fish.

Nók-cvpē-háukē, sturgeon.

Nók-es'se, the mane.

Nók-fehpv, wind pipe, throat.

Nokhókan, pained, painful.

Nokhókē, painful.

Nokhókekát, painless, not painful.

Nokhóketv, pass., to be pained, sorry.

Nok-hómpv, a craw or crop.

Nókis, I say.

Nókkē, pain, sickness.

Nókketá, very painful, trouble, sickness.

Nókketv, s., to be sick, in pain.

Nókkícetáyē, noxious, causing pain very much.

Nókkícetv, v. c., s.. to "hurt, cause pain.

Nókkv'nks, he was pained, was sick.

Nók-íketv, s., to be choked.

Nok-méletv, to swallow.

Nokóftē, globular, round.

Nokóftetv, s., to be round.

Nókosē, a bear.

Nokós-nehá, bear's oil, or fat.

Nókosúcē, a cub, young bear.

Nókos-yáhy, wolf bear, brown bear.

Nok-ráhē, quinsy.

Nok'retv, s., to be burned, to burn.

Nokrícetv, v. c., s., to cause to be burned, to burn. 


\section{NOK}

Nokríket, croup, being choked.

Nok'setv, s., to steal food.

Nok-súkcv, sea gull, pelican.

Nok-súlkē, ravening.

Nok-sum'kè, hoarse.

Nok'sv, ravening, given to stealing.

Nók-tvpvr'v, back of the neck.

Nók-vtar'kv, dew-lap, gills of a cock, etc.

Nok'wv, the neck.

Nókwv-ohwákkv, yoke, ox yoke.

Nómat, if.

Nomélketv, s., to sup.

Nóretv, s., to be cooked, to cook.

Norícetv, v. c., to cook, bake.

Norícv, a baker, a cook.

Norótetv, s., to shake or wag the head.

Norotícetv, V. c., to shake or wag the head.

Notvk'hv, the jaw, the jole, the chin.

Notv'khv-yékcē, lock-jaw.

Notv'kpē, the chin.

Nucáyetv, s., to gape, yawn.

Núcē, sleepy.

Nucépetv, s., to sleep.

Nucétv, s., to sleep, slumber.

Nucicēc'etv, v. c., s., to make sleep.

Nucíce-cv'ketv, p., v. c., to cause to sleep.

Nucícetv, s., to sleep.

Nucicv'ketv, p., to sleep.

Nuc'kv, sleep.

Nuc'kv-ēlē, sleepy, dead asleep.

Nuc'kv-ēlē-ómē, stupid, drowsy, sleepy.

Núcvtēn, sleep.

Nute, a tooth.

Nútē-fvs'ke, eye-tooth.

Nútē-hómv, front tooth.
NUT

Nútē-nok'kē, toothache.

Núte-rak'ko, tusk, double tooth.

Nútē-sémfúlletv, tooth pick.

Nútē-spas'kv, tooth brush.

Nu-yákv-tvlófv, New York town on Deep Fork.

$\mathrm{Nv}^{\prime} \mathrm{ce}$, the side, Env'cē.

Nvcóma? how many? how much?

Nvcómeko, not many.

Nvcómē-mahe, very many.

Nvcómen? a few, how many?

Nvcómet, few, it is few, scarce.

Nv cómus, scarce, few.

Nvcómusē, very few.

Nvcómen? how many?

Nv'f kē-ték-áyetv, s., to knock them down.

Nvf'ketv, s., to strike, buffet, smite, knock.

Nvfkv'ketv, p., to strike, smite, to buffet.

Nv'pv, who, no one, a person.

$\mathrm{Nv}^{\prime} \mathrm{pvt}$, it is no one.

Nvr'kē, the belly, stomach.

Nvr'ke-lowvc'kē, the abdomen, the bowels.

Nvr'ke-ofv-hopvn'ke, inflammation of the bowels.

Nvrkēs'etv, s., to be with child, to conceive.

Nvr'kv'kv diarrhea, flux.

$\mathrm{Nv}^{\prime} \mathrm{rkvk}^{\prime} \mathrm{v}$-cáte, flux, dysentery.

Nvrkv'pucē, bit, dime, the little half.

$\mathrm{Nv}^{\prime} r k v^{\prime} p v$, the half, in the midst.

Nvrkvp'v-enhiyv't'kē, Thursday. Nvrkvpv'-wak'ketv, to lie between.

Nvthof'uce, a little room, corner, closet.

Nvthof'v, in the house, within, a room. 


\section{OCA

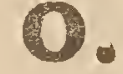

Ocakétv, p., to place, to lay on.

Ocakv'lv, oysters.

Ocáton, having.

Ocè, hickory, hickory nut.

Ocē-cápko, pecan, long hickory nut.

Ocē-cap'kucè, pecan.

Ocē-cap'kucē-vpē, pecan-tree.

Ocē-hērē, plentiful.

Ocekó, has none.

O'cekvs, let it be.

Océkvs, let him have it.

Océpekvs; let alone, let be, hold on.

Oce-penósa, small kind of hickory.

Ocepetv, s., (intensive) to have.

Ocē-rak'ko, large hickory.

$\mathrm{O}^{\prime}$ cès, there is, we have.

Ocē-tof'kv, pignut, small hickory nut.

O'cetv, s., to have, to be.

Ocē-vpè, hickory tree.

$\mathrm{O}^{\prime}$ cof, in due time.

Ocofv'hkvn, at the proper time.

Ocvk'etv, p., to have, to be.

O'crkvképetv, p., to have, to be. Ocv'lke, owners, rich, the wealthy.

Of, $\mathrm{O}^{\prime} \mathrm{fv}, \mathrm{O}^{\prime} \mathrm{fvn}$, in within.

$\mathrm{O}^{\prime} \mathrm{fv}$-em-pv'tckv', lending.

$\mathrm{O}^{\prime} \mathrm{fv}$-hv tekpíkv, drawers.

$\mathrm{O}^{\prime} \mathrm{fv}-\mathrm{v}^{\prime} \mathrm{tcetv}$, underclothes.

Oh, on, upon.

Oh-ákhvt'tetv, s., to shut up.

Oh-akvsvm'etv, s., to believe on.

Oh-akvsvm'kvn, faith.

Oh-apvlecetv, s., to cull, to pick over.

Oh-áretv, s., to go or be about.

Ohatvlíyetv, s., to add.

Oh-áyetv, s., to go to, move on.

Oh-cákev'lket, having had.

Oh-céme-céhpēs, they climbed on. Oh-cémketv, s., to climb upon.

\section{$\mathrm{OHC}$}

Oh'cen, by chance, it happened.

Oh-conécetv, s., to carry to a place.

Oh-cvféknic'vres, will restore, make well.

Oh-crn'etv, s., to pour in or on.

Oh-ēnoc'kv, the collar.

Oh-fes'ketv, s., to sprinkle upon.

Oh-feskv'ketv, p., to sprinkle upon.

Oh-feskv'lkē, spriıklers, Presbyterians.

Oh-fohíketv, s., to sound on.

Oh-foh'ketv, s., to sound on, applied to wind.

Oh-ful'ketv, p., to return to.

Oh-fulkúecetv, v. c., s., to cause to return.

Oh-fullèc'etv, v. c., to turn to or on.

Oh-fullecícetv, s., to restore, make return.

Oh-ful'letv, p., to go about on.

Oh-fvníket, had ruled over.

On-fvn'ken, a ruler, conqueror.

Oh-fvnket, over, being over.

Oh-fvnketv, s., to rule over, to conquer.

Oh-fv'nkvk'etv, p., to rule over, to conquer convince.

Oh-fv'tcè, the judgment.

Oh-fvtcec'etv, v. c., s.; tu prove, to judge, to set right.

Oh-fvtcéckv-nétty, the day of judgment.

Ohfvtcécv, a judge, regulator.

Oh-fvtcehcátskvs, p., judge not, you judge not.

Oh-fvtc'etv, s., to judge, condemn.

Oh-fv'tcè-tetáye-, the judgment.

Ohfvit'cr, towards, into, the judgment, at, for.

Oh-fvtc'v-áyetv, (Vhóyetv, Vpéyetv,) to go towards. 


\section{$\mathrm{OHF}$}

Oh.fv'tcv'kekáren, that you be not judged.

Oh-fvt'cvn, concerning, about, the judgment.

Oh-fv'tcvtón, concerning.

Oh.háyetv, s., to build on, make on.

Oh-hayvk'etv., p., to build on, make on.

Oh-hécv, spectator, observer.

Oh-hepvk'єtv, s., to push to or upon.

Oh-hérkenv'ketv, a funeral sermon.

Oh-híyayícvtèn, shining, upon.

Oh-hiyayv'ketv, p., to shine upon.

Oh-hócetv, s., to spread on, to gain, put on.

Oh-hómpétucē, a stand, little iable.

Oh-hómpetv, a table.

Oh-hóntv, usury, interest.

Oh-hotcíckv, a desk, writing table.

Oh-hoyvnecícetv, v. c., S., to make it pass over.

Oh-hoyvnecic'kv, made it pass over.

Oh-hoyv'netv, s., to pass over.

Oh-hoyvn'kv, passover, the passing over.

On-huéretv, s., Ohsehóketv, Ohsvpv'kletv, to stand on.

Oh-huéretv, stirrups.

Oh-hueric'kv, footstool.

Oh-hv'rpē, out side bark.

Oh-hvtvlíyetv, s., to multiply, increase.

Oh-hvtv'pecícetv, s., to let down on.

Oh-káketv, d., to sit on, to ride.

Oh-káletv, s., to pour on.

Oh-kalv'lkē, pourers, Methodists.

Oh-káyetv, s., to lay on, put on.

Oh-kérkuéckv, a traitor, a betrayer, a witness.

\section{OHK}

Oh-kerkúecetv, s., to confess, report, testify.

Oh-ker'retv, to find out, to judge. Oh-kerrícetv, s., to judge, reprove, condemn.

Oh-kusv'petv, s., to be eager, desirous.

Oh-lakisátskvs, accuse not falsely. Oh-láksetv, s., to slander, tell lies on.

Oh-letiket, had run to.

Oh-let'ketv, s., Oh-tokor'ketv., d., Ohpefat'ketv, p., to run upon.

Oh-lic'etv, s., to sit up, or on, to put on.

Oh-lik'etv, a chair, bench, stool. Oh-liketv, s., to ride on, to sit on. Oh-lvtikekós, shall not fall on.

Oh-lvtiketv, s., to fall on.

Oh-lv'tketv, s., to fall on.

Oh-méklketv, the kingdom.

Oh-mékketv, s., to reign over.

Oh-mekusv'petv, s., to pray over, to ask a blessing.

Oh-mérretv, s., to bless, to have pity on.

Ohnékrícetv, s., to offer sacrifice, (to burn upon.)

Oh nekric'v, a priest, one who offers sacrifice.

Oh-neréketv, s., to prop on.

Ohóketv, a cough, catarrh.

Ohóketv, s., to cough.

Ohóketv-kvr'pe, consumption, dry cough.

Oh-onv'kè, noisy, chatty.

Oh-onv'kv, the fame, rumor, noise.

Oh-onv'pv, on, upon.

Oh-oníyv'kè-táyē, liable.

Oh-pátcetv, an anvil, shield.

Oh-pátcetv, s., to hammer on, beat on. 


\section{$\mathrm{OHP}$}

Oh.pefátecícetv, s., v. c., to make them run upon.

Oh-péfátet $v$, s., to run upon.

Oh-péfátketv, p., to run upon.

Oh-pof'ketv, s., to blow on.

Oh-pok'etv, s., to cast into, to lay into.

Oh-potóketv, s., to hold the head over one side.

Oh-potúecetv, s., to cover, cover over.

Oh-pvlv'tetv, s., to pour on, fall on.

Oh-pvlv'tketv, p., to pour on, fall on.

Oh-pvtákv, a saddle, a covering.

Oh-pvtákv-háyv, a saddler, a cover-maker.

Oh-pv'tcètv, s., to put over, to saddle.

Oh-pvtícetv, s., to saddle, to spread over, cover.

Oh-ránetv, s., to cover, overshadow.

Oh-rolópè, a year.

Oh-rólopē-cukpe-hv'mken, one century, hundred years.

Oh-rólopē-hv'mken, one year.

Oh-rólupē-hv'mke-v'nke,last year.

O'h-rv'nkè, ever since it took place, the past.

Oh-rv'nkē, covered.

Oh-rvn'ketv, s., to be covered.

Oh-rvn'kv, a cover, covering.

Oh-sátkv, a counter, desk.

Oh-sehóyetv, d., to make stand upon.

Oh-sehoyíckv, a foot-stool.

Oh-sv'lkv, a scaffold, a lath.

Oh-svllécetv, s., to lay on.

Oh-táhē, a scaffold.

Oh-tíhè, up stairs, upper room, scaffold.

Oh-tof'ketv, s., to spit on.

\section{OHT}

Oh-tokórketv, d., to run upon.

Oh-tópv, upstairs, a bridge.

Oh-tótetv, s., to send to or on.

Ohtótvtē, sent to.

Oh'-tvhihókē, accursed.

Oh'-tvhihóketv, s., to be accursed.

Oh-tvlécícetv, s., to translate.

Oh-vkérricetv, s., to think on, reflect up n.

Ohv'nketv, victory.

Oh-vpákat, besides, moreover.

Oh-vpáyat, added to, beside.

Oh-vpáyetv. s., to add to or on.

Oh-vpellicetv, s., to overshadow.

Oh-vpóketv, p., to seat.

Oh-vpókv, a seat, a shelf.

Chvpókv, shelves.

Oh-vssotóketv, s., to cover under the wing or arm.

Oh-vssóyetv, s., to put up, or on shelf.

Oh-vtvlákat, else, beside, adding, longer.

Oh-vtvláken, more, increase, gain, any more.

Oh-vtvláketv, s., to increase, to gain.

Oh-vtvlákusen, a little more.

Oh-vtvláyetv, s., to increase, spread out.

Oh-wíkekv, performed on, laid on.

Oh wíketv, s., to leave, cast out, perform.

Oh-wvkécetv, s., to lay up.

Oh-wv'ketv, s., to lie on.

Oh-wv'khokícetv, v. c., d., to be laid on.

Oh-wvkíket, laid on.

Oh-yēkcícetv, s., to force, to urge.

Oh-yomúcē-cícetv, s., to darken.

Oh-yvtékhóyetv, s., to interpret. 


\section{$\mathrm{OHY}$}

Oh-yekhócetv, s., to be forced. $\mathrm{Ok}$, or Okv, for, lest, because.

Oká? what is it?

Okat, saying, answering.

Ok-cátē, reddish, scarlet.

Ok cótkv, musk-rat.

Okcv'n-crm'pē, saltish.

Okcv'n-enkor'kv, salt mine.

Okcv'n-heléswv, epsom salts.

O'kcvn-rákko, saltpetre.

Okcvn-vpáyetv, s., to salt, put salt to it.

Okcvn-vteh'kv, salt cellar.

Okcv'nwv, salt.

$\mathrm{O}^{\prime} \mathrm{ke}$, saying, also water, dust.

Okē-fenókē, shaking water.

Okekós, not time.

O'ken, saying, spoken of.

O'ketv, the time, season.

$\mathrm{O}^{\prime} k e t v$, s., to speak, to say.

$\mathrm{O}^{\prime}$ ket, being in season.

O'ke-yehá, 'mosquito.

Ok-fv'skē-tvlófv, name of a Creek town.

Ok-hácekon, grave, serious.

Ok-hácē-máhē, mirthful, very laughable.

Okholáttē, bluish.

Okhopérette., pale blue.

Okhv'twè, whitish.

Okik'v, as I say.

Okís, I say, I speak.

Okkos'etv, S., to wash, wash the face.

Okkosv'ketv, p., to wash, wash the face.

Oklánē, brown, yellowish.

Oklánè-omè, swarthy.

Oklustícetv, v. c., s., to bruise.

Oklvfónv, cock spur.

Oklvstè, scarlet, blood-shot, blackish.

Oklvwáhē, slime, pit, mud-hole.

Ok-nēhá, gravy, sop.

\section{$\mathrm{OKO}$}

Okóf kē, muddy.

Okómetv, s., to be soft, limp.

Okórv, the sap.

Okóretv, s., to bud, sprout.

Okorv'ketv, p., to bud, sprout.

Okosómē, an ulcer, boil.

Okotafécetv, V. c., s., to make float.

Okotáf kē, floating.

Okotáf ketv, s., to float.

Okotafkv'ketv, p., to fluat.

Ok-peréhè, frizzled.

Okper'kv, night hawk.

Oksópketv, s., to suck.

Oktáhēe, sandy.

Oktahv'tcē, sand creeks "the North Fork."

Oktáh-hv'tkē, sand-bar, white sand.

Oktáhv, sand.

Oktáhv-áksúmóhē, quick-sand.

Oktáhv-semméketv, mosquitobar.

$\mathrm{O}^{\prime} \mathrm{kv}, \mathrm{Ok}$, for, lest, because.

Ok'vtes, was spoken of.

Okvtēt-ókv, for, spoken of.

Okyv'nwv, a cat fish.

Omáhusē, seldom.

Omáhv, seldom.

Omákekv, as far as.

Omáketv, p., to do.

Omáten, it was.

Omat, as, if.

Omátsken, p., you doing.

$\mathrm{O}^{\prime} \mathrm{m} \bar{e}$, like, as.

Omécetv, s., to liken, be like.

Omecícen, causing, because of.

Omécícetv, v: c., s., to make like, to cause.

Omekó, not like, not so, could not.

Omekon-omat, if not.

O'mekv, for, it is.

Omekvn'tes, they do not. 


\section{OME}

$\mathrm{O}^{\prime} \mathrm{mes}$ is, is like.

Ométská, s., is it so?

Om'etv, s., to be, to be like.

Omíkv, for.

O'mis, yet.

Omísem, like as.

O'miyat, swimming.

Omíyetv, s., to swim.

O'mof, then, at, at that time.

O'musè, quite like.

O'musis, like to, like as.

Omv'keko, could not.

Omv'ketv, p., to be, to be like.

Omv'ks, not, not so.

Omv'ks, I am not.

Omv'kusē, like to.

Omvlécetv, s., to take all.

Omv'lkv, all, every one.

Omvrómē, going to be like.

Omv'tcrs, be thou like.

Omviéhkvn, like, to be like.

On, like.

Onáyetv, s., to tell.

Onáyv-ránis, I am going to tell.

Onáyvtēt, having told him.

Ont, like, like manner.

Onv'kv, the saying, word.

Onv'pusè, a little along.

Onv'pv, upon, above, upper.

Opécetv, s., to swing.

Opēlófv, a swamp.

Opélwv, a swamp, bottom.

Opíkè, twisted.

Opíkv, twisted, twist.

Opor'kv, a cut worm.

Opunákeko, dumb, mute.

Opunáyēcáketv, p., to take council.

Opunayécan, fame, report.

Opunáyécetv, s., consult, take council.

Opunayéckv, fame, report.

Opunáyetv, s., to proclaim abroad.

\section{OPU}

Opunáyv, a talker, orator.

Opunv'kv, a word, voice, rumor.

Opunv'kv-ehákv, slander.

Opunv'kv-enháyē, slanderous.

Opunv'kv-en-háyetv, s., to slander.

Opunv'kv-enháyv, slanderer.

Opunv'k'vsan, news.

Opunv'kv-sárv, news-carrier,messenger.

Opunv'kv-svhopákv, a parable.

Opunv'kv-svwahécetv, to report.

Opunv'kv-yékcēe, an oath.

Opunv'kv-yvlúnkv, text.

Opúswr, soup, juice, tears.

Opv, an owl.

Opv-efv'iv, screech ow].

Opv-estékenè, horned owl.

Opv'fkv, the lungs, lights.

Opv'fkv-ennóke, pneumonia.

Opv'kv, apricot-vine, passionflower.

Opv'netv, s., to dance.

Opv'nketv, p., to dance.

Opvn'kv, a dance.

Opv-wákv, praire owl.

O'rat, coming.

Oré, had come.

Ore, worthy enough, fully so.

Oréfketv, s., to kick anytking.

Orē-hēren, sufficiently.

O'reko, looking, wanting, not enough, unworthy.

O'rekotós, is not worthy.

O'ren, until.

Ore-ómē, worthy.

Orétv, s., to come, appear, remain.

O'retv, s., to be worthy, full.

Orícen, meet, suitable.

Oricáketv, s., to have not.

Orícetv, s., to come from, to pass.

Oricéyetv, p., to come.

Oricv'kes, be worthy. 


\section{ORK}

Orko, paupaw, en edible fruit.

Orof, in, within, when he came.

Orófvn, in, within.

Orólopè, a year.

O'rusè, sincerely.

Orvfécetv, s., V. c., cause to lengthen.

Orv'f ketv, s., to be lengthened.

Orv'kè, worthy.

Orv'ketv, s., to be worthy.

Orvkót, not worthy.

O'rvks, had not come.

Orv'nke, it did occur, or arrive.

Orv'nke-kv, for it did occur, or arrive.

Orvron'ko, unworthy.

Os, contraction of omes, is, or is like.

Osá, poke-root.

Osáf kē, saf kee.

Osáhwv, a crow.

Os'iketv, s., to rain.

O'skè, rain.

O'skē-eshetútē, hail, sleet.

O'skè-eshótvlè, stormy.

O'skē-lopútskè, mist, drizzle.

O'sken tácv, rainbow.

O'skē-séko, drouth, no rain.

Os'ketv, s., to rain.

Os'kē-was'kucē, mist, drizzle.

Oskícá, rain-maker.

Oskícetv, v. c., s., to cause rain.

Os-kicv'ketv, p., to cause rain.

Oskóletv, s., to rain.

O'skucē, showery.

Os'set, going or coming out.

Os'setv, Wólketv, Sóssetv, to go out.

Ossícetv, s., v. c., to drive or cast out.

Os'ten, four.

Ostohkáken, four upon.

Ostv'ketv, s., to be four-footed.

Ostvpáken, nine upon.

\section{OST}

Ostvpoh'-kaken, nine upon.

Osv'lkv, a joist.

Osvn'v, an otter.

Osvn'v-hvr'pē, otter skin.

Ot, On, Ont, like, (from Ometv, to be.)

Otáketv, s., to embrace.

Otē, an island, the beach.

Otó, chestnut.

Otóhetv, s., to be damp, moist.

Otóhē, damp, moist.

Otohícetv, to make damp, moist.

Otoh'usē, a little damp.

Oto-wos'kè, chestnut month, October.

Otowos'kucē, (a little chestnut) September.

Otowóskv - rákko, October, big chestnut month.

Owáletv, s., to prophesy, to conjure.

Owálv, prophet, conjurer.

Owalv'lke, p., prophets, conjurers.

Oyap'kv, à pillow.

Oyap'kv-ensuk'cv, pillow-case.

O'yé, a mourner, $i$. e., a widow or widower.

O'yetv, s., to mourn.

Oyev'lkē, p., widows, or widowers, mourners.

Oyókē, lean, faint.

Oyókè-háketv, s., to pine away; be lean, faint.

Oyókusē, rather lean.

\section{P. \\ Same as English.}

Pacáte, course.

Pákkē, leavened, risen, swelled.

Pákketv, s., to rise, be leavened.

Pákketv, dropsy, swelled.

Pakkúeckv, leaven, yeast.

Pak'sè, to-morrow. 


\section{PAK}

Pak'se-vsímv, day after to-morrow.

Paksvn'kē, yesterday.

Paksvn'kē-vsiyvn'kē, day before yesterday.

Paktóksē, mouldy.

Pal, Paul, the Apostle.

Palē, ten.

Palē-cáh'kepen, fifty, five tens.

Palè-cénvpáken, eighty, eight tens.

Palë-epáken, sixty, sixty tens.

Pale-hokkólen, twenty, two tens.

Palē-kulvpáken, seventy, seven tens.

Pálen, ten.

Pálen-hokkolóhkaken, twelve.

Pálen-hv'mkvntvláken, eleven.

Pálen - tútcen-ohkáken, thirteen, three upon ten.

Pálē-ósten, forty, four tens.

Pále-óst vpáken, ninety, nine ters. Pálē-pálen, ten tens, one hundred.

Palépetv, s., to lend, borrow.

Pale-tutcénen, thirty, three tens.

Papa, eater.

Pápetv, s., to eat.

Paptésvm, baptism.

Paptíset, was baptizing.

Paptísetv. S., to baptize.

Paptishókvrēs. shall be baptized. Paptis'kan, when he was baptized.

Paptiskat, is baptized.

Paptisv'ketv, p., to baptize.

Paptísvkit-ohmis, I have baptized.

Paptísvkit-omis, I baptized.

Paptisv'kvres, he will baptize.

Paptísvmē, baptism.

Paptísvrēn, he may be baptized.

Paptísvtēt, being baptized.

Páretv, s., to split, crack.

\section{PAR}

Párkē, split, cracked, riven.

Pas'etv, s., to sweep, clear away.

Paskófv, dancing ground.

Pas'sv, button snake root, from the passv the Indians make their black drink.

Pásv, sweeper, also the maw.

Pat'cetv, s., to mash, to beat, to hammer.

Páto, a meadow.

Paúwucē, a little uncle, (of man or woman.)

Paúwv, an uncle.

Pèce-cékusē, wooly.

Pecéhē, wooly.

Pefátketv, p., Tokórketv, d., Litketv, s., to run, flee from.

Pefátketv, flight.

Peféhle, bloated.

Pef'kē, bloated.

Pekóhcetv, S., to bend, bow down.

Pekóhlícetv, s., to bend, bow down.

Pel'sepvp, Beelzebub.

Penéhe, curly, as the hair.

Pen-éts'kè, a turkey hen.

Pénholócv, a peafowl.

Pen-hv'ce-hērv, a peacock.

Penkále, skittish, fearful.

Penkalécet, frightening, making afraid.

Penkalécetv, v. c., S., to frighten, make afraid.

Penkáletv, to fear, be afraid.

Penkálv, a coward.

Penkvláketv, p., to fear, be afraid. Penkvlēhcátskvs, do ye no vio. lence.

Penkv'lkè, fearful, dangerous.

Penkv'lkv, a fear, afraid.

Pénos'sv, hickory sprouts.

Péntekas, Pentecost, fiftieth day。

Penútkè, bent, turned at the edge or point. 


\section{PEN}

Pen'wv, turkey.

Pen'wv-entówe, turkey beard.

Per'ro, a boat, ship, canoe, trough.

Pérro-capko, long boat, a keel boat.

Pérrocē, a small boat, a skiff.

Per'ro-cúko, a ship, the ark.

Per'ro-és-fullv'lkē, boatmen.

Per'ro-híyv, steamboat.

Per'ro-Jvn'cr, a skiff.

Per'ro-páletv, s., to ferry.

Per'ro-pálv, ferry-man.

Per'ro-polókè, keel boat.

Per'ro-tvpéksē, flat-boat.

Per'ro-tíketv, ferry, ferry boat.

Pes'sè, milk, the udder.

Petetéke, in coil, coiled.

Péyetv, s., to rub.

Pihecékcēesod.

Pihketv, so, to whoop, to bray.

Pihkunáyv, a whooper, news carrier.

Pipókv, delivered up, was cast.

Piketv, s., to put in, go by.

Píyecícetv, S., v. c., cause to rub.

Píyetv, s., to rub.

Plesuytevlke, Presbyterians.

Plēst, a priest.

Poc'ketv, s., to squirt or spit.

Pofi'ket, s., had blown.

Pófketv, s., to blow with a horn.

Póf ketv, trumpet, blowing horn.

Pohè, hearing.

Póheko, deaf, deafness.

Pohépetv, s., to hear, to ask, beseech.

Póhetv, s., to hear, to ask, beseech.

Póhketv, s., to hear, to ask.

Pohyv'kè, p., lonesome, sad.

Póhyvketá, mourning, conjuration.

Pohyv'ketv, p., to mourn, conjure.

\section{$\mathrm{POH}$}

Pohyv'kusē, mourning, lonesome. Pókè finished.

Pokeko, unfinished.

Póketv, s., to be finished, perfected.

Pokkécetv, s., to play ball.

Pokkécetv, ball play.

Pókke-cv'lke- - vlékcv, ball-play conjurer.

Pok'ko, a ball.

Poknv'kv, a nest.

Pok'tv, a twin, twins.

Pókvres, shall be perfected, finished.

Pol'letv, s., to bore, drill.

Polókē, oval, round.

Polóksē, circular, round, a ring.

Polokv'kè, p., oval, round.

Polóyetv, s., to roll.

Pórkv, witch-craft, conjuration.

Pornv, seeds laid up to plant.

Poronetv, s., to rub.

Poróyetv, s., to rub.

Pórretá, witchcraft, conjuration.

Por'retv, s., to witch, to conjure.

Por'rv, wizzard, witch, conjurer.

Pósē, a cat, an aunt, grandmother.

Posiketv, s., to fast.

Pos'ketv, s., to fast, to busk.

Pósucē, a kitten, small cat.

Potókkvtès, he bowed himself down.

Potókketv, s., to dodge, hold down the head.

Potoyícetv, s., to bow or hold down the head.

Potúecetv, s., to turn a vessel mouth down.

Póyetv, s., to finish.

Poyv'ketv, p., to finish.

Poyv'té, redemption.

Pucá, grandfather.

Pucásē, master, lord. 


\section{PUC}

Pucásetv, s., to master, lord it over.

Pucá-sekó, free, freeman.

Pucá-sekv'-hayvte, S., to free, liberate.

Pucásvkē, p., masters, heirs.

Pucéksē, run down, turned to one side.

Pucus-hēcēpvkwv, a tomahawk pipe.

Pucus-tówucē, a rice bird.

Pucus-tvléksēe, broad axe.

Pucúswucē, a hatchet, small axe.

Pucúswv, an axe.

Púecetv, s., to cause.

Púehe, dished, narrow mouthed.

Puehícetv, s., to make dished, double together.

Puehúsē, little dished, narrow mouthed.

Pul'le, our feet.

Pul'sè, droopy, tardy, sickly, ill.

Pulsetá, very unwell, slothful.

Pul'setv, s., to droop, to be unwell, sluthful.

Pulsícetv, s., v. c., to make droop, unwell.

Púlsvkúecetv, v. c., p., to make droop.

Púmat, give us.

Púmēe, we, us.

Pume-temfv'tcetv, atonement.

Púmetv, s., to give us.

Pum- $f v^{\prime} t c \bar{c} c v$, our justifier, judge.

Pum-fv'tcv, our righteousness, justification.

Pum-hóyvtē, p., given us.

Punákets, it is ours, ours.

Punat'tv, eatable or tame animals.

Punat'tv-seminóle, wild beasts.

Punat'tv-yvmv'sv, tame beasts or animals.

Punáyeko, dumb.

Punáyetv, s., to talk, to narrate, to tell.

\section{PUN}

Punáyécvrvnt, going to talk about.

Punáyv, a talker.

Púncé, switchel, treacle.

Punv'k-mehénwv, true talk, orthodox.

Punv'kv, talk, language.

Punv'kv-hēra, the gospel.

Punv'kv-kocók'net, laconic, short talk.

Punv'kv-sárv, messenger, angel.

Punv'kv-yvlúnkv, text.

Pupákat'-tis, those with us.

Pur'kē, our father.

Púrketátē, our ancestors, fathers.

Purkv'lkè, p., our fathers.

Púrwv, seed, stock, cattle.

Pussvl'etv, s., to dream.

Pussvl'kv, a dream.

Puyvfékcv, soul, spirit, mind.

Puyvfékcv-ensúlucv, chrysalis, cocoon.

Puyvfékcv'lkē, ghosts, spirits.

Puyvfek'cv-hv'svtkē, Holy Spirit, pure spirit.

Puyvfek'cv-vcákat, Holy Spirit.

Puyvfékcv-vpvkē, spiritual.

$\mathrm{Pv}^{\prime} \mathrm{ce}$, pigeon.

Pv'cē-hówē, a dove.

Pv'cè-lánē, a parraquet, parrot.

Pvces'setv, S., to leap to one side, to dodge.

Prcessícetv, v. c., S., to make leap to one side.

Prcok'sē, deformed, a dent place in vessels.

Pvf'ketv, so, to strike with the hand.

Pvfkvk'etv, p., to strike with the hand.

Pv'fnè, fast, rapidly, on foot.

Pvf'neta, very fast.

Pvfnetv, s., to be fast.

Pv'fpvn'etv, s, to go fast, rapidly. 


\section{PVF}

Pv'fpvnv'kétv, p., fast, to go rapidly.

Pvh'ce, broom-straw, tall grass.

Pv'hē, grass, hay.

Pv'hē-cus'wv, meadow.

Pv'hē-espvtákv, a straw bed.

Pv'hè-estac'kv, scythe.

Pv'hē-estac'kv-emvp'e, a snath, sneed.

Pvhē-lanóme, green, like grass.

Pv'hē-ok'holat'te, blue grass.

Pvhē-swar'kv-mvp'e, a snath, sneed.

Pvhē-yek'cv, crop, grass.

Pvkácv, a commander, officer.

Pvkánucē, a plum, a little peach.

Pvkánv, a peach, sometimes apples.

Pvkánv-cátē, red peach.

Pvkánv-catucēe, red plum.

Pvkánvhó, wild plums.

Pvkánv-hor'kē, cooked peaches.

Pvkánv-kvr'pē, dried peaches.

Prkánv-lánē, green, yellow peaches.

Pvkánv-lókcē, ripe peach.

Pvkorícetv, s., to double.

Pv'kpáks, in bloom, flowering.

Pv'kpvkë, a flower, foam, froth, bud.

Pvkpvk'etv, s., to blossom, to foam.

Pvkvf'etv, s.. to stab, to pierce.

Pvkvhóretv, s.. to stitch, to sew.

Pvláketv, p., to lend, hire, give.

Pvlé, barley.

Pvlécetv, s., v. c., to make lend.

Pvlépetv, s., to lend, hire, give.

Pv'letv, s., to lend, hire.

Pvlhvm'kē, one side, the other side.

Pvlhvm'kē-vwíketv, s., to cast over, lie over.

Pvlhvm'ke-wákketv, s., to lie over to the other side.

\section{PVL}

Pvlhvm'kusē, a little one side.

Pv'lkē, gain-saying, answering back again.

Pv'lkē-ócetv, s., to put back.

Pvl'ketv, s., to answer back, gainsay, give back again.

Prlóksēe, a ring, full, round.

Pvl'pícetv, s., to roll to.

Pvlpvhóketv, p., to wallow or roll about.

Pvlpvk'etv, s., to wallow, roll about.

Pvl'sē, a relative, mate, companion.

$\mathrm{Pv}^{\prime} l v$, a lender.

Pvlvk'nv, a pan, a plate, dish.

Pvlvk'nvs-hv'tkē, pewter plate, tin ware.

Pvlv'knv-súfkē, a dish,soup-plate. Pvlvlv'kē, crippled, deadness of the limbs.

Pvlv'tetv, s., to spill, to pour, to throw away.

Pvlv't'ketv, p., to spill, pour out, throw away.

Pv'nkv, a dance, frolic.

Pvn'nē, deep place, hollow, ravine.

Pvnne-suf'kē, deep valley, ravine, deep hollow.

Pvr'ko, grapes.

Pvr'ko-cvm'pv, raisins, sweet grapes.

Pvr'ko-crpófv, vineyard.

Pvr'ko-fvk'v, grape-vine.

Pvr'ko-rak'ko, large grapes.

Pvróyetv, s., to rub.

Pvsáhlécetv, s., to feel with the hands.

Pvsáketv, s., to feel.

Pvs'lé, purslane.

Pvsv'tetv, s., to kill, destroy.

Pvsvt'kan, the dead.

Pvsvt'kat, the dead, being dead. 


\section{'PVS}

Pvsvt'kē, dead.

Pvsvt'ketv, p., to die, kill.

Pvtákē, spread out.

Pvtáketv, s., to be spread out.

Pvtákv, a bed, a pallot, a rug.

Pvtapícetv, p., to spread out.

Pvtícetv, s., to spread out.

Pvtícetv, a line stretched out.

Pvtóketv, s., to stoop down.

Pvtú, mushroom.

Pvtvk'so, a species of cat-fish.

\section{R.}

Stands for hl. Rvro, for Hlvhlo.

$\mathrm{Ra}$, or Ras, around, again.

Ra-áyetv, s., to go around, round up.

Ra-en-kvncápat, under.

Ra-fáyetv, s., to hunt game at a distance.

Rafúlliketskof, when you are converted.

Ra-fúllotécetv, s., to turn, or go round.

Ra-fúllotecv'ketv, p., to turn or go round.

Rafúllótketv, s., to turn round.

Ráhkv, a price.

Rahopóyetv, s., to hunt at a distance.

Ráhv, shooter.

Rak-estépketv, horse-whip.

Rak-hóttetv, s., to go and shut.

Rak-hóttvs, go and shut it.

Rak'hvtvpēcícetv, s., to go and carry down.

Rakhvtvp-huécetv, v. c., s., to make go and carry down.

Rakhvtvp'ketv, s., to go and carry down.

Rak'kè, s., large, great.

Rak'kē-máhë, s., very great.

Reak'ketá, very large.

Rak'ketv-máhe, most large.

\section{RAK}

Rak'ko-menóckv, hames.

Rakkuécetv, s., to make great, bro ght up as children.

Rak-ohkákv, light horseman.

Rakporóyetv, s., to go down and rub.

Rakpv'letv, s., to turn over.

Rakpvlketv, p., to turn over.

Rakpvlrícetv, v. c., p., to turn over.

Rak-pvr'etv, s., to go down and split anything.

Rak'pvwuce', minnows.

Rakrvkke, p., large.

Rakrvk'ketv, p., to be very large.

Rakuécetv, to bring up.

Ra-kvwap'ketv, s., to rise again.

Ra-kvwap'kv'ketv, p., rise again.

Rámetv, s., to uncover.

Ramv'ketv, p., to uncover.

Ránet, about to do anything.

Ránetv, s., to overshadow, overcome.

Ranv'ketv, p., to overshadow, overcome.

Ra óh-wvlv'pecícetv, s., v. c., to throw over from.

Ra-oh-wvlv'pecicv'ketv, p., v. c., to throw over from.

Ra-oh-wvlvp'ketv, s., to come back over.

Ra-oh-wvlvpkv'ketv, p., to come. Ra-os'setv, s., to come out from. Rápē, opposite, against.

Rapúecetv, to be against, oppose. Rápv, an adversary, opponent.

$\mathrm{Ras}$, or Ra, around, again.

Ras-en-toh'ketv, s., to drive back with.

Ras-en-tohkv'ketv, p., to drive back with.

Rasofothúecet, haling, arresting. Ras-os'setv, p., to come out from. 


\section{RAS}

Ras-toh'ketv, S., to drive back with.

Ras-tohkv'ketv, p., to drive back with.

Ras-vn-toh'ketv, s., to drive up mine with.

Ras-vn-tóhkv'ketv, p., to drive up mine with.

Ras-v'wetv, s., to bring from.

Rasvwrk'etv, p., to bring from.

Ras-vtétv, s., to bring back.

Ras-wvnáyetv, s., to tie with there.

Rd-tàsketv, s., to jump off.

Ra-táskvs, jump off.

Ra-tohképetv, S., to drive back positively.

Ra-toh'ketv, s., to drive up.

Ra-toh'wvlvpecícetv, s., to throw over from.

Ra-toh'wvlvp'ketv, p., to go over and return.

Ra-wohókv, hog weed.

Rawol'ketv, du., to come out after. going in; s., Ráos'setv, p., Rásos'setv.

Ráwv, a kind of red cane.

Ra-wvnáyetv, s., to tie, (that is at a distance.

Ráyetv, s., to go by, to return.

$\mathrm{Re}$, arrow, lead, bullet.

Recépetv, s., to go and shoot.

Récetv, s., to go and shoot.

Recéyetv, s., to go into.

Recópetv, s., to free, to loosen.

Recópkē, loose.

Recópketv, so, to free, to loosen.

Recopkv'ketv, p., to free, to loosen.

Re-cvláhē, a ringed arrow.

Rè-en-kor'kv, lead mine.

Rē-es-hótcic'kv, lead pencil.

Rē es-rék'kic'kv, ladle.

Ref'ketv, s., to goad, etc., to kick, gore.

\section{$\mathrm{REH}$}

Rē-hákv, arrow wood.

Rēk'kē, melted, dissolved.

Rēk'ketv, s., to melt.

Rekkícetv, v. c., s., to melt.

Rek'kv, easily melted.

Rè-kos'kè, emaciated, starved.

Rekos'ketv, s., to perish, starve.

Re-lopot's-kē, shot, small lead.

Rem, to him, next.

Remáyetv, s., to open the eyes, (as young kittens).

Rem-esécetv, to bring it for him. Rem'hē, thin, scattering.

Remotáketv, to embrace for him. Rem-punáyetv, s., to go and talk to him.

Rem onáyetv, s, to go and tell him.

Rem'pak'sē, to-morrow.

Renákv, eye sight.

Renēnétketv, s., to hum, to buzz. Ren-nvrkv'pv, a half, quarter.

Ren-yúpon, after that, afterwards. Rē-pas'sē, slippery.

Repás'setv, s., to slip.

Res, thence, into.

Res-céyetv, s., to go into, at a distance.

Res-ceyv'kē, p., going in at a distance.

Res-ceyv'ketv, p., to go into at a distance.

Res-ehókv, sticks used to mark the number of games.

Res-emohpíkv, arrow head, iron or tin.

Res-encútkuset, the smallest.

Res-hecépetv, $s_{\bullet}$, to find.

Reshécetv, s., to go and find.

Res-hopíyusen, a little further.

Res'ketv, s., to blow the nose.

Res'ketv, s., to go and drink.

Res-nésetv, S., to buy with, trade with. 


\section{RES}

Res-ar'etv, s., to return, come back.

Resorícetv, s., return to.

Res-oríhocófvn, when they returned.

Respókē, the last.

Res-póyetv, s., to finish, to abolish.

Res-poyv'ketv, p., to finish, abolish.

Res-vcáhképat, fifthly.

Res-vlícetv, s., to pierce up to.

Resvwótetv, s., to vomit up again.

Retêtépketv, s., to make a noise by running.

Retv'ketv, s., to cast out a thick substance.

Retv'petv, s., to rip, to loose.

Re-acvn'kv, bullet-moulds.

Rocópetv, s., to loose, to untie.

Rocopíket, slipping.

Rocópke, loose, untied.

Rocópketv, s., to slip out.

Rófetv, s., to bruise, to scald, to take off hair.

Róf kē, bruised, scraped.

Róf ketv, s., to be bruised.

Roh-honvp'sē, descendants.

Roh-hvlátetv, s., to go and take.

Roh-yúpv, afterwards.

Roh-welv'pketv, s., to go over to. Rokáfetv, s., to whip, beat.

Rokaf'kv, a whipping.

Róketv, s., to pull out.

Rok'kè, out of socket, out of joint.

Rokróyetv, s., to undress, pull out.

Rolvh'pv, muscles.

Rolvkíket, worn into holes.

Rolvk'ke, having holes.

Rolvk'ketv, s., to wear or drop out.

Ron'ks, is not.

\section{$\mathrm{RON}$}

Róno, prairie flies.

Rono-lánē, green horse flies.

Rono-lopútskè, small horse flies.

Rono-lv'stē, big horse flies, black.

Ronóto, gun flint.

Ropotécetv, p., to go through.

Ropot'te, through.

Ropóttetv, s., to go through.

Ropottícetv, v. c., s., to make g॰ through, put through.

Rorē, there, to, unto.

Róren, getting there, came, enter in.

Róretv, s., to get there, enter in, be there.

Rorícetv, p., to get there, to enter.

Rórof, when he came, entered in. Ros'we, slender.

Rotak'ketv, s., to crack.

Rotakkuécetv, v. c., s., to crack a whip.

Rotak'kuec'kv, a whip.

Rotakkúeckv'pē, whip stock.

Rotak'vpē, red bud, Judas-tree.

Rvfécetv, s., to transplant, or to set out.

Rvf'ke, transplanted, or set out. Rv'fo, Winter.

Rvfo-cúsē, January, (i. e., little winter).

Rvfo hákof, Autumn.

Rvfok'sē, slender.

Rvforakko, December, (i.e., big winter).

Rv'hetv, s., to hit by shooting, to sting.

Rvhewites, might sting, be shot.

Rvh'kē, shot.

Rvh'ketv, p., to be shot, be crucified.

Rvhopíyē, further on, away yonder. 


\section{RVH}

Rv'hv, elder brother, when used by a man; and elder sister, when used by a woman.

Rvhv'lkē, p., elder brothers, or (fem.) elder sisters.

Rvkpv'swucē, minnow, (fish).

Rvkpv'swv, small perch or minnow.

.Rvlvkétv, s., to come back, to return.

Rvlvkhóketv, d., to return.

Rvm'kè, open.

Rvn'è, mount, a mound.

Rv'n-rvcuk'wuce, humming bird.

Rvnrvpétv, s., to go and meet.

Rvp-áyetv, s., to go and put with.

Rvpē, against.

Rvpekócetv, s., to go and bend.

Rvpíketv, s., to cast into.

Rvpóhetv, s., to inquire for.

Rvprk'etv, s., to go and stay with.

Rv'ro, fish.

Rvro-as'sv, fish chaser.

Rvrocvnvk'sē, drum fish.

Rvro-lvs'tē, a black fish, buffalo fish.

Rvro-pápv, a fish-hawk.

Rvro-polókē, pike fish.

Rvro-polok'se, chub fish.

Rvro-póyv, s., a fisher, fisherman.

Rvro-poyvl'kē, p., fishermen.

Rvro-rak'ko, a whale, big fish.

Rvro-tvpek'sē, flat fish.

Rv'stē, 'Thursday.

Rvtak'etv, s., to snore.

Rvt'ce, the back.

Rvt'cē-kup'hē, a camel, a hump. back.

Rvt'etv, s., to return.

Rvthóyetv, d., to go from.

Rvtícetv, s., to propagate, spread out.

Rvtoh'ketv, s., to drive off.

\section{RVT}

Rvtosécetv, S., to unfold, to stretch.

Rvtóskē, unfolded, spread out.

Rv'wetv, p., to return.

$R v^{\prime} y e t v, s .$, to come by, return.

\section{S.}

Sáfkē, an Indian dish, boiled hominy.

Sáf kē-hvt'kē, white safkee.

Sáfketok'sē, sour saf kee.

Sah'kapvnetv, s., to play with, play tricks.

Sah'kopánv, a gambler.

Sáhsēkos, none at all, never.

Sah'ses, there was.

Sak'pē, dry.

Sapéot, Sabaoth.

Sápetv, s., to scratch with.

Sap'ketv, s., to sip.

Sap'kv, a scratch.

Sápokè, burdened.

Sapókv, a bundle, a burden.

Sapolícetv, s., to pack on horse back.

Sap'svwē, striped.

Sap'svwécusēe, a little striped.

Sap'svwēcr'kusē, p., a little striped.

Sapsv'wusē, a little striped.

Sapsv'wv, stripe.

Sapsvwv'kusēe, p., striped.

Sárv, a messenger, runner, angel.

Sásē, there is, some, any.

Sáseko, there is none, not inany, not any.

Sásekv, for there is.

Sásēs, there are, some.

Sásetv, s., it is, to be some.

Sas'setv, s., to pursue with, to be with.

Sassv'ketv, p., to pursue with, to be with.

Sasv'kwv, a goose, a brant. 


\section{$\mathrm{S} \Lambda \mathrm{S}$}

Sásvrēn, some one.

Sátetv, s., to mark, to rule. Sat'kē, a task, a day's work.

Sat'kē-rak'ko, an acre.

Sat'kv, a line, rule, target, mark. Sátvtēe, Saturday.

Sauh'ketv, s., to snort.

Saúkv, a rattle.

Saúkv-rak'ko, a big rattle.

Sauwóretv, s., to splinter.

Sauwótetv, s., to splinter, crack, burst.

Sáwetv, p., to bring.

Sáyetv, s., to go with, to carry.

Sayulas'ketv, s., to swing.

Scvmunk, habit.

Se, or Es, with.

Seaholan'ē, rust, excrement.

Secá, black-jack, scrub oak.

Secē, with you.

Secēpéyetv, s., to deliver you up.

Secēpēyvk'etv, p., to deliver you up.

Secéyetv, p., Sec-ayetv, Secvhoyetv, to go in with you.

Secéyof, when they went in with you.

Sec'hetv, s., to shoot with.

Sec'hetv, a marble.

Séco, dew.

Sēcoh', against you.

Sē-emv-háyetv, s., to practice.

Sē-enfiyvt'ketv, s., to navigate.

Se-eietákuécetv, s., to arm one's self, make ready.

Seháyet, a while, waiting.

Sēhoc'kv, cunning.

Sẻhóketv, du., to stand.

Sēhonécka, a miracle, a wonder. Sēhonec'kè, fearful, wonderful, awful.

Sēhonec'ketv, s., to be wonderful.

Sēhoneckv'ketv, p., to be wonderful.

\section{SEH}

Sēhóyē, d., standing.

Sēhóyetv, du., to place, make stand.

Sekáte, there is none.

Sekēhóyof, when he was stabbed.

Sekéyetv, s., to stab, pierce.

Sēkó, none, gone.

Sēkohákvtes, it is extinct.

Sēko-hvpet'tic'kucē, parasol, lit-. tle umbrella.

Sēko-hvpettic'kv, umbrella.

Sēko-kapvtókvn, helmet.

$\mathrm{S}$. kókv, for there is none.

Sekóst, is not, is gone, is none.

Séks, gone, is none.

Sekscv', gone, is none.

Seláhlecv'kē-witet, he might tear.

Selákséketv, s., to scream.

Seláwv, hawthorn.

Sēletv, s., to slice, rive, split.

Selkè, s., slit, split, slice, riven.

Selsécetv, po, to slice, to rive, split.

Sēlsékē, p., split, slit, sliced.

Selv'hlécetv, s., to tear up, or in pieces.

Selvhlecv'ketv, p., to tear up.

Selvkétv, p., to split, slice, rive. Sem, Sen, Se or Es, with, to, unto.

Sem-akcaúkv, a skimmer.

Semákv, fan, a fin.

Semákwíkv, fish-worm.

Semelak'setv, s., to defraud, deceive.

Semeláksv'kétv, p., to defraud, deceive.

Semetētac'kv, a bond.

Seme.vpáyv, with the prince or leader.

Seme-vtót'ketv, s., to gear up.

Seme-vtotkv'kétv. p., to gear up.

Semfēp'kv, fringes.

Semfiyat'kv, the helm of a ship. 


\section{SEM}

Semfulot'kv, a wheel, a mill.

Semfulot'kv-semwēs'kv, a fanning mill.

Seminóle, Seminole, wild, runaway.

Sem-oh-sēhóyetv, s., to put on for him.

Sempelot'kv, a helm.

Sem-punáyetv, s., to talk together.

Semun'tvlēn, more, more than, worse.

Semúntvlétv, s., to have more.

Sem-vhákv, with the law.

Semvles'kvpē, envious.

Semvles'kēpēt, being envious.

Semvleskv'petv, p., to grudge, envy.

Semvlícetv, s., to lock up, to buckle on.

Semvlicv'ketv, p., to lock up, buckle on.

Semvlíkv, a lock, buckle.

Semvlúmhv, a button.

Semvlv'ketv, s., Semvlahoketv, du., Senyícetv, p., to bring.

Semvnatépkv, a shield.

Semvníckv, in use.

Semvnickv-séko out of use.

Semvnvc'kusē, little handsome.

Semvnv'c'kv, s., handsọme.

Semvnv'ckv'ke, p., handsome.

Semvnv'ckv'kusē, p., little handsome.

Semvteh'kē, pie, custard.

Semvivtéhá, ruffles.

Semvyékcícetv, s., to wedge, to bind.

Semvyékcíckvn, fetters.

Semvyékcicv'ketv, p., to wedge, to bind.

Semvyékcvkuécetv, v. c., p., to wedge, to bind.

Sen, Sem, Se or Es, with.

\section{SEN}

Sencap'kēe, longer.

Sen-cek'kotkv, a cork.

Sencek'kotkv-sossícetv, cork screw.

Sencókv, branding iron.

Sencut'kē, less, small, smaller.

Sencut'kuse, very little, least.

Sen-écē, in rows.

Senehic'kv, ornament.

Senepécetv, s., to stretch anything.

Senepecv'ketv, p., to stretch anything.

Senep-huécetv, p., v. c., to stretch, make stretch.

Senep'ketv, s., to stretch one's self.

Senepkvketv, p., to stretch one's self.

Senhec'ke, something wonderful, a vision.

Senhérē, s., better.

Senhéretv, s., to be better.

Senherv'kè, p., better.

Senhervkemáhet, much better, very good, is best.

Senhonechókēe, wonders.

Senhonéckvket, fearful, wonderful.

Senhon'nen, heavier, greater, more than.

Sen-kor'retv, s., to dig with.

Sen-korrvkétv, p., to dig with.

Senkv'nhetv, a snare.

Sen-kvpvkétv, p., to part with, to remit, forgive.

Sen-luéyepuécetv, s., to harrow. Sen-lúeyepuec'kv, harrow.

Sen-lúeyepúecvk'etv, p., to harrow.

Sen-nokmelkv, a gullet, esophegus.

Senrak'kē, s., larger.

Sen-rak'rvkē, p., larger.

Sen-sátetv, a pencil, a marker. 


\section{SEN}

Sen-síyetv, s., to grease with.

Sen-siyvkétv, p., to grease with. Sen-ton'kv, shears.

Sentvc'ketv, s., to forbid, prevent, turn away.

Sen-tvc'kē, a dam, as a mill dam, etc.

Sen-yek'cē-kókv, is not harder, is easier.

Sen-yicakétv, p., to bring many. Sen-yícetv, p., to bring, come with.

Sen-yukfvn'kv, a lash of a whip.

Sen-yvmvs'etv, s., to oblige, to please.

Sen-yvmvsvkétv, p., to please, to oblige.

Seoképkv, excuse, gain-saying. Sepekáres, there will be none. Sepekátes, nothing lacking, there was nothing.

Sepeko, none.

Sepekv't-háks? Was anything lacking?

Sépelvn, the town of Zebulon.

Sepoh-áyetv, s., to lead us to, Sepohvhoyetv, du., Sepohvpeyetv, p., to lead us to.

Sep-ossícetv, s., to deliver, cast out.

Sepossícvs, turn us out, deliver us.

Sépvres, will take.

Sepvs, take it.

Sérak'ketv, chastity, virtue.

Sesíyetv, s., to rub. with, to grease.

Sesketúcē, a cup, teacup.

Sesketúce-ehúte, cupboard.

Sesketùcē-empvtákv, saucer.

Ses'ketv, a mug, cup.

Séśketv, s., to drink with.

Ses'ketv-rak'ko, a bowl, goblet.

Seskvkétv, p., to drink with.

\section{SES}

Ses'tem, (S, and Este,) of men or with men.

Sestemer'retv, s., to suffer with.

Séstemerrvkétv.p., to suffer with. Séstepenkalécr a robber.

Sestesum'kv, a snail.

Sestokemahétv, s., to be noisy. Sestókemahvk'etv, p., to be noisy. Sétaúkv, a boat pole.

Sétē, between.

Sete-cas'etv, s., to rake with.

Setecas'kv, a rake.

Setécetv, matches.

Sétehécet $v, s_{\text {. }}$, to meet.

Sétehecvkétv, p., to meet.

Sétehóretv, s., to buckle, to button.

Sétehorvk'etv, p., to buckle, to button.

Sete-hoyánvrēn, should carry through.

Setékcvncicetv, p., to mingle, mix.

Setékcvn'etv, s., to mingle, to mix.

Setekef'kv, a rake.

Setéketv, s., to melt and drop.

Sētek'kekv, a crutch, staff.

Sétekvkétv, p., to melt and drop. Sētekvp'vkē, division, chapter.

Sētelókpic'kv, sealing wax, wa. fers, glue, etc.

Sètem, with them.

Sêtem-áhkopvn'etv, s., to gamble with.

Sētem-áhkopvnvkétv, p., to gam. ble with.

Sètem-fek'etv, wages, payment.

Sētem-fvt'cetv, covenant, agreement.

Sêtemfvt'cetv, s., to covenant, to agree.

Setem-war'kē, division, chapter, verse. 


\section{SET}

Setem-war'kuce, a little chapter, verse, room.

Seténkvpvkétvn, separation, divorcement.

Seténkvpvk'etv, s., to separate, divorce.

Setén-kvwvp'kv, hand-spike.

Setén-tac'kv, a vail.

Seténtvc'kē, a chapter, division.

Setén-tvkhv'kē, a column.

Setén-yvpos'ketv, s., to swap.

Setén-yopóskvkétv; p.. to swap.

Setépokícetv, to clap the hands together.

Sētepókv, armor.

Setetáyen, each of them.

Setetáyvké, enough.

Setetek'etv, s., to gnash, grind the teeth.

Setetéket, gnashing.

Sētetékkvkétv, p., to gnash, grind the teeth.

Sètetépketv, s., to clap.

Sétetv, s., to tear.

Sèteyámetv, s., to stir with.

Sèteyámvkétv, p., to stir with.

Sete-yopos'ketv, s.. to pass each other.

Sete-yopóskvk'etv, p., to pass each other.

Setke, torn, ripped.

Sêtken', the rent, or torn place.

Setken', might rend, be torn.

Set'ketv, s., to rip oneself.

Setkvkétv, p., to rip oneself.

Sèto-rof'kv, a frock, dress.

Setsécetv, p., to tear.

Sētvk'etv, p., to tear.

Se-vhesáketv, s., to inspire.

Se-vpáyetv, s., to lead, conduct. Se-vpáyv, an officer, leader, ruler. Se-vpayvk'etv, p., to lead, conduct.

Se-vres'ketv, s., to sniffle, snifter.

\section{SEV}

Se-vrvnvk'v, a shield.

Se-vtot'ketv, tools to work with.

Se-wap'ho, sauce, pomato.

Se-wvk'te-oket, shrill noise.

Se-wvnak'etv, s., to gird oneself.

Se-wvnak'etv, girdle, belt.

Se-wvnakuécetv, v. c., s., to belt or gird others.

Se-wvnakúecvkétv, p., to belt or gird others.

Se-wvnákvkétv, p., to gird them. selves.

Seyáskeháketv, s., to be humble.

Se-yvhólvn'etv, s., to rust, "cover the feet," ease one's self.

Se-yvholvnvk'etv, p., to rust, "cover the feet," ease themselves.

Sic'etv, s., to bring forth young.

Sih'netv, s., to leak.

Sihnvk'etv, p.; to leak.

Sísetv, s., to beget.

Siyetv, s., to carry.

Skot'kv, scissors.

Skot'kv-rak'ko, shears.

Skvlaf'kv, drawing knife.

Slaf'kucē, a pen knife, pocket knife.

Slaf'kv, a knife.

Sláfkv' cap'ko, sword, long knife. Sláfkv-hútē, scabbard, knife house.

Sláf kv-rak'ko, a big knife, butcher knife.

S-mokkícetv, s., to smoke.

S-mokkicvketv, p., to smoke.

Snésv, buyer, trader, clerk.

Sofotécetv, s., to drag

Sófotecrk'etv, p., to drag.

Sofothuécetv, v. c., p., to drag.

Sofóthuecvk'etv, v. c., p., to drag.

Sofot'ketv., s., to drag oneself.

Soh, to, on, with. 


\section{$\mathrm{SOH}$}

Soh-ahóyetv, d., to carry to.

Soh-áyetv, s., to carry to.

Soh-cèmécetv, p., to climb with, cause to climb with.

Soh-cemhóketv, d., to climb with.

Soh-cem'ketv, s., to climb with a ladder, stairs.

Soh céyetv, p., Oh-ceyetv, to go into.

Soh-fv cécetv, s., to fulfill, fill up.

Soh-fv cecvk'etv, p., to fulfill, fill up?.

Sohfvn'ketv, s., to rule with.

Soh-fv'nkvketv, p., to get higher with.

Sohfv'cēcéyē-tayet, fulfilling.

Soh-húeric'kv, hinge, candle stick, lamp stand.

Soh'huerícetv, s., to cover, cover over.

Sóh-húerihoh'cen, placing, having placed.

Sóh-hvlátkv, suspenders.

Sóh-let'ketv, s., to flee to.

Sóh-lokpícetv, s., to seal.

Sóh-nekricetv, s., to sacrifice.

Sóh-nekric'kv, sacrifice.

Sób-nekricvk'etv, p., to sacrifice. Sóh-pac'kv, an apron.

Soh-pefat'ketv, p., to flee to.

Sóh-pvc'etv, s., to pound on it.

Soh.pvcrkétv, p., to pound on it.

Soh ref'ketv, s., to kick with.

Soh-réf kvketv, p., to kick with.

Sóh-rvn'kv, a cover, curtain, a lid.

Sóh-teh'kv, a boot.

Sóh-teh'kv-svhopákv, a boot tree. Sóh-tokor'ketv, d., to flee to.

Soh-tvlíkē, run aground, (a man's name).

Soh-vpet'tv, shed, piazza, porch pinnarle.

Soh-rpéyetv, p., to carry, to go with.

\section{$\mathrm{SOH}$}

Soh-vpóyetv, s., to shelve, put in shelf.

Sóh-vpv'yetv, s., to add.

Sóh-welep'kv, saddle-bags, valise. Soh-wetenétv, s., to squeeze on.

Soh-wetenvketv, p.,to squeeze on. Sóh-wv nákv, girth, surcingle.

Sokéhtv, moth, (fuund on hides, etc.,) cricket.

Sok'hē, fitty, convulsive.

Sok'hetv, fit, convulsion.

Sókhetv, s., to have fits.

Sokholáttéckv, indigo.

Sokhv'kétv, p., to have fits.

Sokkósetv, s., to wash.

Sokkos'etv-tomutkē, wash tub.

Sókkos'kv, soap.

Sokkos'kv-vteh'kv, soap dish.

Sok'so, black bug, black bess.

Sok'tv, a bug.

Solotécetv, p., v.c., to make slip.

Solotécícetv, s., v. c., to make slip.

Solótetv, s., to slip.

Solotíket, having slipped.

Sóskv, the itch.

Sos'sè, out of.

Sóssetv, s., to go out.

Sossícetv, S., V. C., to cast out.

Sossicv'ketv, p., v. c., to cast out.

Sossv'ketv, p., to go out.

Sowenv, hemp.

Sowénv-fvskë, hemp.

Spískucē, allspice.

Spískv, spice.

Spókv, the end.

Sropóttv, a needle.

Sropóttv-rákko, big needle.

Sropóttv-vtéhkv, needle-case.

Stéfv-pecvpē, water-flag.

'Stellepik-spáskv, shoe-brush.

'Stélle-píkv, a moccosin, a shoe.

'Stellepíkv-wvnhē, shoe.

'Stélle sv - oh-cac'kv, stocking, sock.

'Stelles-wvnákv, a garter. 


\section{STE}

Stēmerrícetv, s., to punish, to suffer.

Stemérrvkuécetv, p., to punish, suffer.

Stenēpíckv, a flat iron.

Ste-tvrófv-eshv'svtec'kv, a face towel.

Stófis, ever, sometimes.

Stomécetv, s., to happen.

Stomècv'ketv, p., to happen.

Stómis, anywhere.

Stos-kumétskéko-háks? Do you not care?

Stv'kanec'kv, blister-plaster.

Strkkéfkv, shovel.

Stv'k-hec'kv, a glass, looking glass.

Stv'kvo-wéckv, starch.

Stvn'-tos, don't know.

Stv'tvlákv, nettle.

Stv'tvlákv-rak'ko, nettle ball.

Súcvpiyéckv, plow.

Súcv piyéckv-sláfkv, a coulter.

Sufécetv, s., to make deep, to deepen.

Sufécrk'etv, p., to deepen, make deep.

Suf'kē, deep.

Suf'kē-laúkē-laúkē-yomuc'kē, a deep, dark pit.

Súfsokè, deep, lower part.

Sufsúcetv, S., v. c., to deepen.

Sufsucv'ketv, p., v. c., to make deep.

Súfsvkē, p., deep.

Súkcv, a bag, pocket.

Śíkcv-hótcv, braided pouch.

Súkcv-tvpékse, shot pouch.

Sukéhtv, a moth.

Súkhucè, a pig.

Sukhucv'l'kè, pigs.

Suk'hv, a hog.

Suk'hv-cúle, a boar, an old hog.

Suk'hv-hoktv'lwv, an old sow.

\section{SUK}

Suk'hv-hunv'nwv, a boar.

Suk'hv-hv'tkē, an opossum.

Sukhv'l'kē, hogs.

Súkbv-nēhá, hog's lard.

Súkhv-tého, a barrow.

Súkhv-vpéswv, hog meat, pork.

Súkpē, rough.

Suk'sv, the hip.

Súkv, lye hominy.

Sulē, a buzzard.

Sulécè, much, rich.

Sulécetv, s., to be rich, lay up treasure.

Sulēlek'nv, sparrow hawk.

Suletáwv, soldier.

Suletawv'ikē, soldiers.

Suletáwv-ómē, military.

Suletáwv-pvkácv, a general, cap-

tain, etc.

Súlkē, many, much, a herd.

Sulsókè, many, large number.

Sulsókemáhe, a great many, large multitudes.

Súlusuécetv, s., to shuffle.

Súlusúecv'ketv, p., to shuffle.

Sumécat, the lost, being lost, pass away.

Sumécetv, s.: V. c, to get lost, to lose one, perish.

Sumēcícetv, v. c., s., to lose, to destroy, pass away.

Sumécicvketv, p., to lose, destroy, pass away.

Sumhóketv, du., to get lost pass away.

Sumhúecetv, v. c., s., to lose, destroy.

Sumhúecv'ketv, v. c., p, to lose, destroy.

Sumképetv, s., to be lost or de. stroyed.

Sum'ketv, destruction.

Sum'ketv, s., to get lost, or destroyed, pass away, flee. 


\section{SUM}

Sum'kis, I am lost, destroyed. Sum'kv, a deserter, destroyer. Sumkvránēs, we about to perish. Sunec'kè, a journey.

Supáktv, a toad, a frog.

Supv'khv't'hv'ke, p., gray color. Supvkhvt'kē, s., gray color.

Supvkhvt'ke-óme, roan color.

Sútv, the sky.

Suwénv, silk grass.

Suwésowē, locust or jar fly.

Sv, S, Svc, Es, Se, Svn, with.

$\mathrm{Svc}^{\prime}$, with.

Svcáyetv, s., to land with, lead me.

Sv-cáyv'kétv, p., to land with.

Sv-cenvpákē, eighth.

Sv'cvcrkécetv, s., to rattle as a snake.

Sv'-cvcv'kecvkétv, p., to rattle as a snake.

Sv'C-vkérrícetv, S., to remember me.

Svc-vkérricvkétv, p., to remember me.

Svc-vhóyetv, du., to lead me.

Sv-crkcrhéckv, side combs.

Svcrn'kv, a funnel.

Svc-vpéyetv, p., to lead me.

Svféklum'ketv, s., to turn on one side.

Svféklúmkvk'etv, p., to turn on one side.

Svfi'yetv, screw, screw-nail.

Svfi'yetv - esemfulótetv, screwdriver.

Svfvc'etv, s., to supply, fill up.

Svfv'lke, thrown.

Svfv'lkv, anything thrown, club. Svfvl'letv, s., to fling, cast.

Svfvllvk'etv, p., to fling, cast.

Svfvs'tetv, S., to apply, to execute, attend to.

Svfv'stvk'etv, p., to apply, execute, attend to.

\section{$\mathrm{SVF}$}

Svfv'tcetv, S., to apply, attend to. Svfv'tcv, straight with, behind something.

Svháye, hypocritical.

Svháyetv, s., to imitate, be a hypocrite.

Svhayv'ketv, p., to imitate, to be a hypocrite.

Svhērēmáhē, very great.

Sv hērēmáhe-hákes, made greater. Svhērēmáhekv, very great, greater. Svhērēmáhetv, s., to be very great.

Svhērēmáhetv, excess, abundance.

Svhēremáhkat, p., not good, very bad.

Svherēmáhken, the more, the greater.

Sv'hkopv'nkv, a play-thing, toy. Sv'hocáckv, stockings.

Svhókkolat, twice.

Svhókkolè, secondly.

Svhókkólv, second.

Svhólotóhfv, a barren desert.

Svhólwákē, dirty, nasty, bad.

Svhopákv, a sign, a parable.

Svhopayáts'kat, you measure, 2nd person $\mathrm{pl}$.

Svhopáyēsko, beyond measure.

Svhopáyetv, s., to make sign, to liken to.

Svhopoyésko, beyond measure.

Svhóyetv, du., to carry.

Svhvtec'kvtē, a watch, matches. Svkas'kv, a razor.

Svkcáuētv, s., to dip, draw out. Svkcaúkv, dipper, ladle.

Svkcéyetv, p., to go into water. Svkcēyícetv, p., v. c., to make go into water.

Svkcēyicvk'etv, p., v. c., to make go into water.

Svkcó, a crab,a craw-fish, lobster. 


\section{SVK}

Sv'kco-rak'ko, lobster.

Sv'kcv'wetv, s., to dip.

Sv'kcvwrk'etv, p., to dip.

Svkekáres, it will be impossible.

Svkēk'etv, s., to be impossible.

Svkēpēkókv, "for they are not."

Svker'kucē, a pint cup, a gill.

Svker'kv, a measure.

Svker'kv-hvm'ken, a bushel.

Svkérkv-nvrkv'pv, half bushel.

Svkérkv-nvrkv'pv-énnvr'kvpv, a peck measure.

Svkhécetv, s., to find, or see in water.

Svkhécvk'etv, p., to find, or see in water.

Svkhot'kv, a door, shutter, gate.

Svkkélv, black bird.

Svkkélv-rak'ko, jackdaw.

Svkkēpuec'kv, a trap, steel trap.

Svk'kv, a basket, carried on the back.

Svklícetv, s., to dip up.

Svk-morécetv, s., to fry.

Svkmoréckv, frying-pan, skillet.

Svkmórecvk'etv, p., to fry.

Svk-nvf'ketv, s., to knock with, in water.

Svk-nvfkvk'êtv, p., to knock with in water.

Svk'pv, an arm.

Sv'kpvklícv, the arm-pit.

Sv'kpv-mvháukè, arm-hole.

Sv'kpv-seko, without arms, a ves'.

Svláho, bringing.

Svlahóketv, du., to bring.

Svláhwv, a riddle, coarse seive.

Svlekwícetv, a dung hill.

Svlicáketv, p. to set over, put to. Svlícetv, s., to write down, set over, put to.

Svlíkv, pad-lock.

Svlok'petv, S., to stick, to glue, to paste.

\section{SVL}

Svlokpícetv, s., v. c., to stick, to glue, to paste.

Svlokpíckv, glue, paste, anything that sticks.

Svlokpicvk'etv, p., to stick, to glue, paste.

Svlumbícetv, s., to put or write down.

Svlumhicvk'etv, p., to put or write down.

Svlumkv'ke, written down.

Svlv'fkē, a servant, a prisoner, slavery.

Svlv'f ket, oppression, subdued.

Svlvfkuécetv, s., to capture, oppress, make a prisoner.

Svlvfkuecrk'etv, p., to capture, to oppress.

Svlvf kuehócē, a prisoner.

Svlvf kvl'kē, servants, prisoners.

Svlvh'wē, wide apart, a riddle, seive.

Sv-lvk'etv, s., to bring, i. e., come with.

Svm, with, same as Svn, Sv, Se, Sen, Sem, Es, Se, etc.

Svmahlécetv, s., v. c., cause to rattle.

Svmáhlecv'ketv, p., v. c., cause to rattle.

Svmáhlètv, s., to rattle.

Svmáhlv'ketv, p., to rattle.

Svm-mvuéttakis, I am younger.

Svmómus, the best, the chief.

Svmómuse, little better.

Svmómvkus, the best, the chief.

Svmónh-háyetv, s., to accustom.

Svmónk-háyetv, s., to accustom.

Svmónkhayv'ketv, p., to accustom.

Svmorécetv, s., to fry with.

Svmorecrk'etv, p., v. c., to fry with.

Svmóretv, s., to fry with. 


\section{SVM}

Svm'pv, a basket.

Svm-vféyetv, S., to grease, to anoint.

Svm-vfēyvkétv, p., to anoint.

Svmvhóyetv, du., to carry for me.

Svm-vláketv, s., to bring to me, come with it.

Svm-vmak'ketv, s., to tingle.

Svmv'në'cetv, s., to jingle.

Svm-vpéyetv, p., to carry for me.

Svm-v'yetv, s., to carry for me.

Svn, with, (same as Sv, Svm, Se, Sen, Sem, etc.)

Svn-cáletv, s., to paint.

Svn-hērícetv, s., to benefit, make good.

Svn-hërícvk'etv, p., to benefit, make good.

Svntalvk'wv, a perch.

Svn-téckv, s, a hindrance.

Svntv'cke, forbid.

Svnv-c'omv, over. again, any more, longer.

Svav'comv-hec'ketv, regeneration, born again.

Sv-nvf'ketv, a mallet, a mawl.

Svn-v'tecetv, s., to hinder with.

Svn-yek'ces, is mightier, is stronger than $I$.

Svn-yicáts'ken, bring to me, $i . e_{\text {., }}$ come with.

Svpáken, together with.

Svpak'letv, p., Sehoketv, Hueretv, to stand.

Svpehóyetv, pass, the being carried.

Svpénkalécetv, s., to extort, to rob.

Svpénkalécetvn, spoils.

Svpénkalec'kv, extortion, robbery.

Svpénkalecvk'etv, p., to rob, extort.

Svpénkalécy, a robber.

\section{SVP}

Svpēnútetv, s., to bend by.

Svpēnutvkétv, p., to bend by.

Svpéyetv, p., to carry away.

Svpíkv, a drawer.

Svpv'kē, together with.

Svpv'kekat, together, besides.

Srpv'ket, being together with.

Svpv'ketv, s., to be with.

Svpv'klvránat, to tramp on.

Svpr'kprkuecetv, to make it

foam, to foam.

Svpv'k-pvkuec'kv,shaving brush,

$i$. e., foam with.

Svpvk'usē, little mixed.

Svprs'etv, s., to parch with.

Svpvsvk'etv, p., to parch with.

Svpvtécvr-haks? Wherein is its

strength? Seasoned.

Svpv'tetv, to be strong with.

Svráhetv, s., to drive to, or through.

Svráhkv, because of.

Svráhkvtēn, the prints, signs.

Svráhroyetv, v. C., to drive through.

Svráhv'ketv, p., to drive, hammer.

Sv'rretv, s. to nail to, crucify.

Svtáhē, square, trimmed.

Svtahécetv, v. c., s., to make square, to hew.

Svtahécv, hewer.

Svtáhecvkétv, p., v.c., to make square, to hew.

Svtáhetv, s., to be square.

Svtahuécetv, S., to square, to hew.

Sv táhuecvkétv, p., to square, to hew.

Svtáhúsē, a little square.

Svtahvkétv, p., to be square.

Svtáretv, s., to weigh.

Svtar'ketv, s., to be suspended, to hang, to weigh.

Svtárkúcetv, s., to weigh any. thing. 


\section{SVT}

Svtárkucvk'etv, p., to weigh anything.

Svtárkuéckv, steel yards.

Svtar'kv, steel yards also weight.

Svtar'kv-rak'ko, scales.

Svteh'kv, a bin, canister.

Svten'ketv, s., to hold down.

Svten'kvkétv, p., to hold down.

Sv'tetv. s., to bring, to fetch.

Svthóketv, s., to choose, elect.

Svtókucē, a hammer.

Svtókv, hammer.

Sutókv-rak'ko, a sledge hammer.

Svtot'ketv, s., to work with.

Svtotkvkétv: p., to work with.

Svtu.cénat, thirdly.

Sv'tv, persimmon, apple.

Svtvkkákv, a latch.

Svtv'kkatícetv, p., to latch.

Svtv'kkáyetv, s., to latch.

Svtv'k'në, sidewise, sideling.

Svtv'k'nusē, a little ridge, sideling.

Svtv-rak'ko, apple.

Svtv-rak'ko-kvr'pē, dried-apples.

Svtv-rak'ko-lánē, quince, greenapple.

Svwekkélkv, tongs, pinchers, clamp.

Svwelépetv, s., to put anything across, (as a bag, across the horse).

Svwelep'ketv, s., to be across.

Svwelepkvk'etv, p., to be across. Svwelep'kv, saddle bags.

Svwelēprkétv, p., to put anything across.

Svwêten'etv, s., to squeeze with.

Svwëtenvkétv, p., to squeeze with. Svwèten-wécetv, p., to squeeze with.

Svwētenwēcrkétv, p., to squeeze with.

Sv'wetv, p., to bring.

\section{SVW}

Svwótetv, s., to puke, vomit.

Svwot'kv, an emetic.

Svwot'kv-hvt'kē, tartar-emetic.

Svwot'kv lánē, ipecac.

Svwotvk'etv, p., to puke, vomit.

Svwvnákv halter.

Svyók'kofetv, s., to wrap up.

Svoyokkofvkétv, p., to wrap up.

Svyoklasēc'etv, v. c., to swing

anything.

Svyókláse-cvk'etv, v. c , p.; to swing anything.

Svyóklas'ketv, s., to swing.

Svyókláskvkétv, p., to swing.

Svyok'letv, s., to spread out the legs.

\section{T.}

Tácen, cut off.

Tácet, cutting down or off.

Tácet-afulotēcécētv, to circumcise, cut around.

Tácetv, s., to cut down or off.

Tachóyetv, pass., to be cut down or off.

Tac'ketv, p., to cut down or off.

Táfv, a feather, quills.

Tafvm'pē, onions, garlic, scallions.

Tafvm'pē-rak'ko, onions.

Tafvm'pè-enérkv, onion seed.

Tafvm'pē-vhákē, garlic.

Táhwv, lamb's quarter.

Tákē, the plural ending of nouns.

Tále, withered, dead.

Táleiv, s., to wither, die as a tree.

Talv'ketv, p., to wither, die as a tree.

Tálvn, a talent, about $\$$ I, 645 .

Talv'pè, a corn cob.

Tan, even.

Táphē, s., broad, level.

Taphēstákan, p., broad, level.

Tápheton, s., it is broad. 


\section{TAP}

Táphetv, s., to be broad.

Táptáhan, broad.

Taptáhē, p., broad.

Táres, shall be.

Tar'retv, s., to warm by the fire.

Tartvh'kv, cotton tree.

Tártvhóketv, p., rattle, make a noise.

Tártvk'etv, s., to rattle, make a noise.

Tárv, a weaver.

Tasah'cē, spring.

Tasah'cē-rak'ko, April.

Tasah'cucē, March.

Tasécetv, s., to jump, leap.

Tashóketv, d., to jump, leap.

'Tas'ketv, s., to jump, hop.

Táskvk'etv, p., to jump, hop.

Tástvhóketv, p., to prance, jump about.

Tástvkétv, s., to prance, to jump about.

Tat, it is, part. of ometv to be.

Táte, it is, is.

Táten, it is.

Tátēs, it was, was.

Tátèt, it is.

Táwetv, s., to push a boat.

Tawvkétv, p., to push a boat.

Táyat, abundant, sufficient.

Táyen, a great deal, enough, exceedingly.

Táyen-estemer'ket,grievously tormented.

Táyetv, s., to be enough.

Tecak'kat, brothers, brethren.

Tecákkats'kat, ye brothers.

Tecákkéyvtē, brethren, friends.

Tecák'kvtē, brothers.

Tecák-vhóyetv, du., to follow.

Tecáh-vpéyetv, p., to follow.

Tecákáyetv, s., to follow.

Tecákáyē, species, kind.

\section{TEC}

Técelícetv, s., to touch, to gather.

Técelicvketv, p., to touch, to gather.

Técetv, s., to make a fire, to kindle.

Técrkétv, p., to make a fire.

Téfes'ketv, s., to splash.

Téfeskvkétv, p., to splash.

Téfetv, s., to pull off, pull up, to strip.

Tefn'è, dull.

Tefn'etv, s., to be dull.

Tefnícetv, v, c., s., to make dull.

Tefténetv, p., to be dull.

Teftenícetv, p., to make dull.

Tefvkétv, p., to pull up, or off.

Tefv'kyvt'kē, twisted together.

Tefvkyvt'kusē, a little twisted.

Téfvlah'letv, p., to burst.

Téfvlvp'ketv, s., to burst.

Tēhan'etv, s., to quarrel, contend with.

Tèhécetv, s., to meet, to look at each other.

Tèhecvkétv, p., to meet, to look at each other.

Tēheláksécetv, s., to dispute.

Téhelaksecvk'etv, p., to dispute.

Tekápolēs, the town Decapolis.

Téhetv, s., to be castrated.

Tèhícē, s., castrated.

Tëhícetv, v. c., s., to castrate.

Téhicvkétv, p., to castrate.

Tèho, castrated, a eunuch.

Tehónkv, a street.

Tēhoyánen, abounding, going out, by.

Tehóyvnécetv; to make you abound.

Tēhvké, p., castrated, eunuchs. Tēhvkétv, p., to be castrated.

Téhv'lvtēpuécetv, v. c., s., to make them marry, to join to. gether. 


\section{TEH}

Tēhvlvtétv, s., to marry, hold together.

Téhvlvtvk'etv, p., to marry, hold together.

Tèhvn'kv, confusion.

Tékácetv, s., to break in pieces. Tékácéyetv, p., to break in pieces.

Tékáyetv, s., to knock down, or throw down.

Tēkayvk'etv, p., to knock down, or throw down.

Tèkel'kē, wrinkled.

Tèkel'ketv, s., to be wrinkled.

Téken'ketv, s., to stand tip toe.

Tékenkvkétv, p., to stand tip toe.

Tèkērhoyvl'kē, acquaintances.

Téker'retv, s., to get acquainted.

Tékérrvk'etv, p., to get acquainted.

Tek'tvnécetv, v. c., s., to make room, give place.

Tektvn'kat, permanent.

'Tek'tvn'kē, a space, crack, opportunity.

Tek'tvn'ketv, s., to have room or space.

Tekúehokétv, s., to counsel.

Tékuéketv, s., to counsel, take counsel.

Tēkuéketv, a council.

Tēkúekvl'kē, coursellors.

Tékunah'etv. s., to snatch from another.

Tekúnvkétv, s., to snatch from one another.

Tekúnvhv'ketv, p., to snatch from one another.

Tēkv'ksetv, s., to squat.

Tékvksv'ketv, p., to squat.

Tekvpákícetv, v.c., s., to divide.

Tekvpákvkēn, companies.

\section{TEK}

Tekvpáyetv, s., to divide, sepa.rate.

Tékvpayv'ketv, p., to divide. separate.

Tekvpáyvl'kē, p., dividers.

Tékvpíce.tv, s., to divide.

Tékvpicvk'etv, p., to divide.

Tékvpikv'ketv, p., to separate. divide.

Tekvpv'kē, divided, apart, parted.

Tekvpv'ketv, p., to separate, to part.

Tekyv'mketv, an uproar, confusion.

Telaksécētv, s., to dispute, con. tradict.

Teláksecv'ketv, p. to dispute, contradict.

Telékmē, fine, as fur.

Telékmícetv, s., to smash, beat fine.

Telékmicvk'etv, p., to smash, to beat small.

Telékmusēn, fine, (not coarse).

Teléko, wheat.

Teléko-eswar'kv, cradle, scythe.

Teléko-tvklíkē, wheat brèad.

Teléko-vháke, rye, barley, tares.

Telúmhícetv, s., to quilt.

Telúmhicvk'etv, p., to quilt.

Telum'hv, quilt.

Tem, part., for, with, against, with himself.

Tem-ak'vsv'metv, $s_{\bullet}$, to agree with.

Tem-ak'vsvmv'ketv, p., to agree with.

Tem-áretv, s., to run a race with.

Tem-etícekot, making no difference.

Tem-fátcvtēn, s., taking account of.

Tem-fúlletv, p., to run a race with. 


\section{TEM}

Tem-fv'tcetv, s., to covenant, bargain.

Temfvt'cetv, an oath, agreement. Temfv'tcvk'etv, p., to bargain, agree.

Tem'h-técetv, s., to make a noise, thumping.

Tem'h-tecrk'etv, p., to make a noise, thumping.

Tempálvsē, mates, of the same kind, ally.

Tem'pè, near, nigh, at, smooth.

Tempóhetv, a question.

Tempuécetv, s., to come near.

Tempuécv'ketv, p., to come near.

Tempunáhóyetv, p., to converse, debate.

Tempunáyetv, s., to converse, to read, debate.

Tempunáyv, a reader, talker, debater.

Tempvl'se, on each side, a pair. Tempvlsvk'e-, p., on each side.

Temun'tvlè, s., uneven.

Temun'tvlvk'e. p., uneven.

Temvpókē, whole, sound, perfect. Temvpvl'wusē, regular, in order. Temvpv'lwv, with one consent, in order.

Témvrah'ketv, s., to differ.

'Temvráhkvk'etv, p., to differ.

Ten, for, with, against, (same as tem).

Ténakuécv, a neighbor.

Ténakuécvkē, neighborly.

Tenakúecvl'kē, neighbors.

Tenas'pē, slippery.

Tenáspétv, s., to slip.

Tenas'pvkē, p., slippery.

Tenáspvk'etv, p., to slip.

Tén'epè, smooth, glassy.

Tenepícetv, s., to smooth, make smooth.

Tenepicvk'etv, s., to smooth, make smooth.

\section{TEN}

Tenet'kē, thunder.

Tenet'ketv, s., to thunder.

Tenetkvk'etv, p., to thunder.

'Tenfvt'cetv, s., to make an agreement, bargain.

Tenfvtcvk'etv, p., to bargain, make an agreement.

Tenhérkēpuécetv, v. c., to make peace.

Tenhes'setv, s., to make friends.

Tenhes'svk'etv, p., to make friends with.

Tenhórrícetv, s., to make war with.

Tenhorricvk'etv, p., to make war with.

Ténhvlvtétv, s., to hold between. Ténhvlvtvk'etv, p., to hold between.

Tenkvpákvk'etv, p., to part from each other.

Ténkvpvk'etv, s., to part from each other.

Tennes'etv, to trade with.

Tenrápē, against each other.

Tenrapetv, s., to challenge, to oppose, dispute.

Tenráwv, between, amongst, in the midst of.

Tenráwv-ahóyetv, du., to go between.

Tenráwv-áyetv, s., to go between.

Tenráwv-vpéyetv, p., to go between.

Téntvkháketv, s., to agree.

Tényopos'ketv, s., to trade, to deal with, swap.

Tényopóskvkétv, p., to trade, to deal with.

Tényvmv'setv, s., to be friendly. Tényvmvsv'ketv,p., to be friendly. Tepáken, both, besides.

Tepáketv, s., both of you, to be together. 
TEP

Tepákvn, both, besides.

Tep'ketv, s., to whip, scourge.

Tepóktê, close logether.

Tepóktícetv, s., to bend to. gether, to bend.

Tepókticv'ketv, p., to put together.

Tepókv, a battle, a fight.

Tepóyetv, s., to fight with.

Tepóyv, a fighter, warrior.

Tepoyv'ketv, p., to fight.

Tepv'kè, together.

Tepvkócetv, s., to bend, double.

Tepvkóckē, doubled.

Tepv'kocv'ketv, p., to bend double.

Tepvkóhlícetv, p.,to bend double.

Tepv'llapícetv, p., to twist.

Tepv'llapv'kusēe, p., little twisted.

Tepv'llv'kusē, little twisted.

Tepvllv'yetv, s., to twist.

Tepv'llvyv'ketv, p., to twist.

Tepyícet, and.

Ter'opothóyetv, d., to go through.

Teropóttē, through.

Teropottécetv, v. c., s., to cause to go through, put through.

Teropóttetv, s., to go through.

Teropottícetv, v. c., to make go through.

Teropótticv'ketv, p., to make go through.

Tes, it is.

Tetáckv, waist.

Tetahóyetv, d., to be even with.

Tetahóyusè, little even, rather equal.

Tetahoyv'ketv, p., to be even.

Tetákè, ready.

Tetákusē, reasonable, rational.

Tetákvtēt, being ready, prepared.

Tetáye, sufficient, enough.

Tetáyetós, it is enough.

Tetáyetv, s., to be enough, to be even.

\section{TET}

Tetekéke, jointed.

Tetéketv, s., to notch together.

Tetekkéketv, s., to join together.

Tetékketécetv, p., to touch at points, to join.

Tetekketéketv, p., to join together.

Tetékkéyetv, s., to touch at points, to join together.

Tetékkeyv'ketv' p., to touch at points, join together.

Tetekv'ketv, p., to notch together.

Tetkv, a large red-headed woodcock.

Tetv'cetv, s., to cut in two.

Tetvcr'ketv, p., to cut in two.

Tetvkkákv, link in a chain.

Tetvpokkícetv, s., to clap hands.

Tetvpókkicv'ketv, p., to clap hands.

Tewáretv, p., to cut in two.

Tewarv'ketv, p., to cut in two.

Tewarwícetv, s., to cut up.

Tewetéknetv, s., to knit together.

Tewíketv, s., to throw down, (as by wrestling).

Tewíwvhóketv, d., to go after another.

Tewohlícetv, s., to quarter.

Tewóle, near together, often.

Teww, the mane of a horse, lock of hair.

Téwv-tv'rkē, a wig.

Téwvkécetv, s.. to wrestle.

Téwvke-cv'ketv, p., to wrestle.

Teyámetv, s., to stir.

Teyamv'ketv, p., to stir.

Teyékcetv, s., to tangle.

Teyopósecícetv, s., to change, exchange.

Teyósē, or Teósē, Jesus, perhaps frum Deos.

Tiapólv, the Devil, Diabolus, deceiver. 


\section{TIH}

Tihóketv, d., to cross, to ford.

Tihóyē, p., pains.

Tihúcē, a little scaffold.

Tíkar-háks? will I cross?

Tíken, crossing.

Tíketv, s., to cross, to ford.

Tíketv, a ford.

Tikv'ketv, p., to cross over, to ford.

Tis, as, even, so, in like manner, also.

'Tis'em, as, even, so, in like manner.

Titvs, Titus, proper name.

Tiy'e, pain.

Tiyeh'cof, when they had crossed.

To-áhvwv, a chest, or coffin.

To-atólkv, a drum.

To-cv'sketv, a chip of wood.

To-és-cvlléckv, a wagon. or cart.

To-es'sè, leaves of trees.

To-essēlókv, caterpillar.

Tóf ketv, s., to spit.

Tof kv'ketv, p., to spit.

Tofókv, plank, sawed wood.

T.-fóyetv, s., to saw wood, to split wood.

Tofv'mpē, cherry.

To-fv'mpē-v'pe, cherry-tree.

To-fv'sho, black elm.

Toh, logether, over again.

Tohahóyeko, had not come together.

To-háks? is it so?

Toh-áretv, s., to go back and forth.

Tohcekcéfe, p., crowded thick together.

Tohcékfé, s., crowded thick together.

Tóhcopóksē, grouped together.

Tóhcopuscúke, p., grouped together.

Tohcv'sketv, s., to notch up.

\section{$\mathrm{TOH}$}

Tohcrskv'ketv, p., to notch up.

To'réksetv, s., to stand on all fours.

Toheksv'ketv, p., to stand on all fours.

Toh-elleko, misleto, without feet. Tohfúlletv, p., to go back and forth.

Tohkákv, joist, a beam.

Tohkálet, being in partnership.

Tohkálv, a partner, partnership.

Toh-káyetv, s., to bet.

Toh-kayv'ketv, p., to bet.

Tohkv'letv, s., to add.

Tohkv'lkè, together.

Tohkv'lketv, s., to get together.

Tohkv'lketv, fellows.

Tohkvlkicetv, s., to add.

Tohkvlv'ketv, p., to add.

Tohópkē, furt, fence.

Tohópkē-fvsókē, pailings.

Tohópkè-pvr'kè, a rail, rails.

Tohópkttv, s., to fence, to fortify.

Tohopkicetv, v. c., s., to make fence, or fort.

Tohópkv-háuke, a gate or gap of fort or fence.

Tohopkv'ketv, p., to fence, make a fort.

Tohotēlókē, a pile.

Tuhóttowr, powder.

Tonóttvplánē, brimstone, sulphur.

Tohtárv. a builder.

Tohtarv'lké, p., builders.

Tohtasécetv, s.. to jump over.

Tohtashóketv, d., to jump over.

Tohtásketv, s., 10 jump over.

Tohtekk kv, a joint.

Tohtihćketv, d., to cross over.

Toht ketv, s., to cross over.

Tohtiyécetv, p., to cross over.

Tóhto, a barn, crib.

Tohtvlhúecetv, s., to translate.

Tohtvlhuecv'ketv, p., to translate. 


\section{$\mathrm{TOH}$}

Tohtvlhuéckv, translation.

Tohtvlhúecv, translator.

Tohtvr'etv, s., to make fence, to build, edify.

Toktvrv'ketv, p., to make fence.

To-hvlátv, ox, wood drawer.

To-hv'rpē, the bark of a tree.

Toh-vtelóketv, s., to assemble, gather together.

Toh-vtelokv'ketv, p., to assemble, gather together.

Toh-vtelóyetv, s., to gather together, assemble.

Tóh-vteloyv'ketv, p., to gather together.

Tóh-weklépē, crossed at angles.

Tóh-weklépetv, s., to cross at angles.

Tóh-weklépkv, the cross.

Tóh-weklépkvn-oh-vtáretv, s., to crucify, hang on the cross.

Tóh-weklépkvn-oh-vtartícetv，s., v. c., to crucify.

Tóh-w k klepv'ketv, p., to cross at angles.

Tóh-weláketv, d., to go back and forth.

Tóh-welépkvn, saddle-bags or wallets.

Tóh-wvlvpécetv, s., to transgress, go over, as a fence.

Tóh-wvlvphóketv, d., to transgress, to go over.

Tóh-wvlv'pketv, s, to transgress, to go over.

Tok, or Tokv, for, used at the end of a sentence.

Tokárēn, shou'd not.

Tokat, is not, is without any.

Tokátes, was not.

Tokecéskv, a stump.

Tokfe, brackish.

Tokféla, a wart, a wen.

Tokkéketv, s., to kneel down.

\section{TOK}

Tokkekvketv, p., to kneel down.

Toklóswv, spittle, saliva.

Tóko, not, not so.

Tokocv, an ant, a pissmire.

Tokóhē, speckled.

Tokóhusē, a little speckled.

Tokónhē, a ball stick.

Tokorketv, d., Letketv, s., Pefatketv. p., to run.

Tokpáf kè, rotten, (as wood).

Tokpáfkv, rotten wood, spunk.

Tokper'kv, a bull bat.

Tokréskv, a copperhead snake.

Tokrínetv. s., to chew.

Tóksē, sour, not fresh, leavened.

Tokséko, unleavened, not sour.

Toktúswv, the ankle.

Tókv, Tok, or Kv, because, for.

Tokv'cetv, s., to split or break wood.

Tokvcv'ketv, p,, to break or split wood.

Tokv-máhv, Spanish oak.

Tókvs, now.

Tokvsáppv, prickly ash.

Tókwē, pithy.

Tokwucē, herring.

Tokyúlkv, a tadpole.

Tóletv, s., to fall, as a tree.

Tólkē, cut down, fallen.

Tólketv, s., to fall, to cut down.

Tolkvtécv, town crier.

Tolómetv, s., to roll as $\log$.

Tolomv'ketv, p., to roll any thing, as log.

Toltóketv, p., to fall.

Toltóyetv, p., to cut down.

Tolv'ketv, p., to fall, as a tree.

Tómekv, because.

Tómes, it is.

Tómis, although.

Tónetv, s., to cut off the hair, to shear.

Ton'ke, hair cut off, shorn. 


\section{TON}

Tonv'fetv, s., to bruise.

Tonv'fkè, bruised.

Tonvf v'ketv, p., to bruise.

Tonv'ketv, p., to cut off the hair.

Topókucē, shrub.

Tópv; a bed.

Tópv-ec'kv, bed bug,

Tópv-ennvthófv, a bed room.

Topv-fv'kv, bed cord.

Topv-húte, bed room.

Topv'ksē, fresh, tasteless.

Topv'ksuse, fresh, weak, tasteless. Tópv - ohpvtákv, bed-clothes, bed-spread.

Tópv-oh-rv'nkv, a sheet.

Topv'rv, behind, outside, without.

Topv'rv-onv'pv, outside, without.

Toráwv, coal.

Toráwv-en-kórkv, coal mine.

Tor'ketv, s., to nibble, strip.

Torkówv, a knee.

Torkówv-oh-líkv, the knee pan.

Torków-toh-kékekv, knee joint.

Torkv'ketv, p., to nibbie, strip.

Torófetv, s., to skin, to flay.

Torofv'ketv, p., to skin, flay.

Toropv'tkv, an adder.

Tor'pè, a knot, a joint of a corn stock.

Torv'wv, charcoal, coal.

Torv'wv-enkórkv, coal nine.

Tos, (contraction for tomes) it is, are, etc.

Tosáyetv, s., to dust, scatter, drop, sprinkle.

Tosayv'ketv, p., to sprinkle, dust. Tosénv, bacon, anything salted.

Tosélkv, boards, shingles.

Tosélkv-lv'stē-ohhotcíckv, blackboard.

'Tos'kv, the itch, mange.

Totekv'ksē, a pack-saddle.

Tótkv, fire.

Tótkvfúlkv, cotton, cotton cloth.

\section{TOT}

Tótkv-fúlkv-semáckv, cotton gin. Tót'kv-fúlkv-hv'tkē, bleached cotton cloth.

Tótkv-hútē, chimney, fire-place.

Tótkv-rákko, a big fire, hell.

Tótkv-rákko-élkv, hell fire.

Tótkv-setéckv, fire works, matches

Tottolósē, chicken.

Tottólosēechustákē, eggs of a chicken.

Tottólosē-enhóktē, a hen, female chicken.

Tottolósē-enhunv'nwv, chickencock.

Tottolósē-hákof, clucking, crow* ing of chickens.

Tottolosúcē, little chicken.

Totvpéksē, board, plank.

Tówē, old, as bones, cane.

To-wēklépkv, the cross, wood crossed.

Towóskucē, September, little chestnut month.

Towóskv, chestnut.

Towóskv-rákko, October, big chestnut montn.

Towvnv'ké a barrel.

Towvnv'kucè, a keg.

Towvtv'lkv, an Indian drum.

Tóyetv, s., to be.

Toyéyvrēn, l., we should be.

Toyvketv, p., to be.

To-yvlúnkv, the root of a tree.

Túcè, kidney, the reins.

Tufv'petv, s., to crumble.

Tufv pkē crumbled.

Tufv'pketv, p., to be crumbled.

Tufv pkucē, crumbs.

Tukaskēnv, pepper-grass.

Túkfē, astringent, puckery.

Tukóhē, spotted, checkered.

Tukórē, checkered, spotted.

Tukórusé, little spotted.

Tukríhnetv, s., to slobber. 


\section{TUK}

Túkrihnv'ketv, p., to slobber.

Túktukásketv, s., to crackle.

Túktukaskv'ketv, p., to crackle.

Tuláswuicé, the palate of the mouth, little tongue.

Tuláswv, a tongue.

Tulosecícetv, s., v. c., to cause to snort.

Tulosecicv'ketv, p., to cause to snort.

Tulósketv, s., to blow the nose, snort.

Tuloskv'ketv, p., to snort.

Tulpóketv, s., to coil, wrap.

Tulpolúcetv, p., to fold.

Tulpolv'ketv, p., to coil, wrap.

Tulpóyetv, s., to fold, wrap.

Tulvwv, the brim, the edge.

Tum'h-tóketv, s., to throb.

Tumh'tokv'ketv, p., to throb.

Tupv'ksē, fresh.

Turēpe, the eyebrows.

Túrhe, eye-lashes.

Tur-hecv'keko, blind.

Tur-hvce, corner of the eye.

Tur-hv'pv, eye-socket.

Tur-mer'kv, eye-ball.

Tur-nok'kè, sore eves.

Tur-nok'kē-heleswv, sore-eye medicine.

Turófv, the face, countenance.

Tur-opúswv, tears.

Túrwv, the eye.

Tur'wv-ak - wvnayetv, to bind up the eye.

Tur'wv-hvr'pe, eye-lid.

Tur'wv-svkákv, spectacles.

Tus'kucē, small-speckled woodpecker.

Túste, Tuesday.

Tut, or, either.

Tutcénen, three.

Tutcénv, thrice.

Tuwéhtv, the kill deer.
TVC

Tv'cetv, s., to cut, Waretv, p., to cut, as grass.

Tvc kátskekon, forbid you not.

Trc'kè, cut, a piece.

Tv'c kusē, a piece, cut off.

$T^{\prime}{ }^{\prime} c k v t \bar{e}$, scar, cut place.

Tvcó, place of one corner of the square.

Tvffó, grass-hopper, locust.

Tvffolúpv, butterfly.

Tvffo-nóksv, a locust, i. e., Egyptian locust.

Tvfósho, red elm.

Tvhíkē, quarrelsome.

Tvhíketv, s., to swear, to quarrel, curse.

Tvhikv'ketv, p., to swear, quarrel, curse.

Tvhikv'lkē, p., scolders, swearers. Tvhóknē, light, not heavy.

Tvhóknetv, s., to be light, not heavy.

Tvhóknusé, little light, not heavy.

Tvhópkē, active, supple.

Trhóyv, a squash.

Tvhpálv, common runner, town crier.

Tvkáckucē, a reel.

Tvkánē, blistered.

Tvkanécetv, S., v. c., to cause to blister.

Tvkanéckv, a blister.

Tvkanēckv'ketv, v. c., p., to blister.

Tvkanēcv'ketv, p., to blister.

Tvkánetv, s., to blister.

Tvkanv'ketv, p., to blister.

Tvk-es'setv, s., to take up, to take out of.

Tvkētécetv, s., to make a fire.

Tyketecv'ketv, p., to make a fire.

Tvkfápetv, s., to singe.

Tvkfapv'ketv, p., to singe. 


\section{TVK}

Tvkfēeléskv, a bat.

Tvkfúlwucē, a tape, small ribbon.

Tvkfúlwv, ribbon, tape.

Tvkfúlwv-svwvnákv, a sash, (as worn by ladies).

Tvkhócē, a back-log.

Tvkhv'ketv, s., to lie side ways, as by a road.

Tvkhv'ketv, phylactery, a charm, amulet.

Tvkkáketv, d., Tvkliketv, Tvkvpoketv, to sit low down.

Tvkkéketv, s., to kneel down.

Tvkkolécetv, s., to light a fire.

Tvkkolēev'ketv, p., to light a fire.

Tvkkv'fetv, s., to melt.

Tvkkvf-v'ketv, p., to melt.

Tvklátket, being cast into.

Tvklátketv, S., to throw into, fall down.

Tvklécetv, s., to decry, deny, upbraid, blaspheme.

Tvkléckv, blasphemy.

Tvklēcv'ketv, p., to decry, deny, upbraid, blaspheme.

Trklēcv'lkè, despisers, blasphemers.

Tvklícetv, s., v. c., to make sit down.

Tvklicv'ketv, p., v. c., to make sit down.

Tvklíkè, bread, cake.

Tvklike-cv'mpv, sweet cake.

Tvklikē-esnorickv, an oven, bakeoven.

Tvklíke-espakkúeckv, saleratus, baking powder.

Tvklikē-hákv, dough.

Tvklikē-hv'rpē, crust of bread.

Tvklíkē-pak'ko, light bread.

Tvklíke--palv'knv, bread dish, or tray.

Tvklikē-tóksēe, sour bread.

Trkliketv, s., to sit down low.

\section{TVK}

Tvknékretv, s., to burn down in.

Tvkó, ground mole.

Tvkocá, ants.

Tvkócetv, s., to break, to hatch, burst.

Trkócketv, s., to be broken.

Tvkóckē, broken.

Tvkóckusē, a little broken or cracked.

Tvkóckv, a crack, crevice.

Tvkohlicvtet, broken in pieces.

Tvkokfv'mpè, water turtle.

Tvko-pváyetv, s., to stretch the arms.

Trko-pvtayv'ketv, p., to stretch the arms.

Tvkpáfkv, rotten wood.

Tr'kpucúcè, a swallow.

Tv'kpvlv'tketv, p., to fall down.

Tv'ksvpúlkv, a mountain lizzard.

Tv'ktémpē, a hearth.

Tv'kto-kéketv, s., to kneel down.

Tv'kto-kēkv'ketv, p., to kneel down.

Trktópv, floor.

Trkv'cwē, frozen hard, stiff.

Tvkvfúnwv, chinquepin.

Tvkvpóketv, p., to sit down on low place.

Trkvpoyv'ketv, p., to set them down low.

Tv'kvwv, mullet, a small fish.

Tvkwihóketv, pass., to be cast into or down.

Tvkwíketv, s., to cast into, cast down.

Tvkwikv'ketv, p., to cast. into, cast down.

Tvkyúrketv, du., to fall down.

Tvlakē-rákko, the great bird that takes away the souls of the wicked, the devil.

Tvláko, peas, beans. 


\section{TVL}

Tvláko-cápko, cow-peas; blackeyed peas, long bean or pea.

Tvláko-hakè, husks, (as of grain).

Tvláko-pákucē, English pea.

Tvláko-rákko, butter beans.

Tvláphē, stiff, hard.

Tv'le, not cooked, raw, fresh.

Tvlécetv, s., to strip, as of clothes, or bark of trees.

Tvleccr'ketv, p., to strip, as of clothes, or bark of trees.

Tvle-es'sē,bran of corn, wheat,etc.

Tvlelénnv, a flag, a standard.

Tv'lemè, public, or Republic, common.

Tvlèmécetv, S., to make public.

Tv'lemē-erkenv'kv, Evangelist, public preacher.

Tvlemē-v'lkē, public or market place.

Tvlepórē, foreign.

Tvlepórv, a stranger, foreigner.

Tvleporv'lketv, p., to sojourn, journey.

Tvleporv'lkē, strangers, foreigners.

Tvlhúecatskvres, ye shall persecute.

Tv'lke, only.

Tvlkēkon, not only.

Tv'lketv, p., they only.

Tvlkúsē, only.

Tvlkúsetv, s., to be alone.

Tv'lkusis, I only, I alone.

Tvlkvránat, he only shall be, until it shall be.

Tv'lkvrēn, all, that might be all.

Tvlófv, a town or nation, tribe.

Tvlofv'lkē, citizens.

Tvlok'kè, a rain crow.

Tvlok'ko, thrush.

Tvlópe, soap-stone.

T»lràkko, prickley pear.

Tv'lsa, the name of a town.
TVL

Tvlvhássē, old town or deserted town.

Tvlvlícetv, s., to arrange.

Tvlvlicv'ketv, p., to arrange.

Tvlvlv'ke, in ranges, abreast, in tiers.

Tvlvlv'ketv, s., to march in companies.

Tvlv'phe, stiffened, hardened.

Tvlv'swē, sticky, tough.

Tv'lwv, tribe, nation, town.

Tvlwv-vlkē, nations, Gentiles.

Tvlwv-v'lk-em-mékko, Emperor; king of nations.

Tvmécetv, s., to fly.

Tvmécv'ketv, p., to fly.

Tvmhóketv, du., to fly.

'Tv'mketv, s., to fly.

Tvmonh-háyetv, accustomed.

Tv'mvmápkv, a drum.

Tvmvmápkv-náfketv, to beat the drum.

Tvnēcícetv, s., to unload, to desolate.

Tvnëcicv'ketv, p., to unload, to desolate.

Tvnēcícvranat, desolation, or about to desolate.

Tv'nkan, the desert.

Tvn'kē, empty, roomy, vacant, being desolate.

Tv'nkekv, to be empty, for he was.

Tv'nketv, s., to be empty, to be. Tv'nkv, emptiness, space.

Tvnorícvs, s., on the hearth.

Tvnv'psē, turnip.

Tvnv'psē-enérkv, turnip-seed.

Tvpálv, over on the other side, beyond.

Tvpálv-rákkvlkē, Englishmen.

Tvpéksē, flat, broad.

Tvpeksícetv, S., v. c., to widen, flatten, lay flat. 


\section{TVP}

Trpeksicv'ketv, p., to flatten, widen.

Tvpénsusē, level.

Tv'phē, wide, broad.

Tvpocé-cetv, s., v.-c., to fire a gun.

Tvpoce-ecv'ketv, v.c., p., to fire a gun.

Tvpoc'ketv, s., to fire, pop, crack, as a gun.

Trpoc'kucē, a pistol.

Tvpoc'kv, a gun.

Tvpockv'ketv, p., crack, as a gun, pop.

Tvpoc'kv-rákko, a cannon.

Trpóhletv, s., to pop, (as wood in burning.)

Tvpohlv'ketv, p., to pop, (as wood in burning.)

Trpohsv'lv, long-legged spider.

Tvpvsv'nv, mosquito-hawk.

Tvrákē, dry, brittle.

Tvráko, prickly pear.

Tv'retv, to weave.

Tvr'kvres, it shall be only or until.

Tvr'etv-esropóttv, knitting needle, weaver's shuttle.

Tvr'kē, woven, as cloth.

Tvr'kv, anything woven, cotton cloth.

Tv'rkv-hvtécv, a fuller,a whitener.

Tvrókwē, unsound.

Tvr'pv, a wing.

Tvr'pv-láne, the yellow hammer.

Tvr'retv, s., to warm by the fire.

Tvrrv'ketv, p., to warm by the fire.

'Tvrv'ketv, p., to weave.

Tv'rvrvkécetv, s., v. c., to make rattle.

Tvrvrv'kecv'ketv, p., to make rattle.

Tvrvrv'kketv, s., to rattle, as dry stalks.

\section{TVR}

Tvrvrv'kkv'ketv, p., to rattle, as dry stalks.

Tv'sè, jay bird.

Tvsekíyv, one who has received a war name.

Tvskëge, the name of a Creek town.

Tvskocánkusē, p., thin.

'Tvskócē', thin.

Tvskocúsē, very thin.

Tvskócv, calico.

Tv'ssv-sv'nv, king-fisher.

Tvstvnv'kē, warrior, brave.

'Tvstvnv'kuce', little warrior.

Tvtásketv, s., to jump, a summer-set.

Tv'wv, sumach.

Tvwv'knē, lank, lean.

\section{U.}

Pronounced as oo in mood.

Ue-ak-cétto, water-snake.

Ue-aksúmkv'lkē, water divers,

Immersionists.

Ue-aktv'phē, pond lily.

Ue-cátè, red water, Arkansas river.

Ue enfihnē, water-course.

Ue-enkor'kv, a well, a cistern.

Ue-enkor'rv, a well-digger.

Ue-en-nénē, a ditch, canal, course of a stream.

Ue-en-nénucē', a small ditch.

Ue-escaúkv, water-dipper, also a vat.

Ue-escrn'kv, a pail, water bucket. Ue-fih'nē, a current, watercourse.

Ue-fulótkv, whirl-pool.

Ue-fúswv, water bird.

Ue-fv'kucē, small stream, a branch.

Ue-hómē, bitter water, whiskey, brandy, etc. 


\section{UEH}

Uehóme-cátē, wine.

Uehómē-cátē-escrn'kv, win e press.

Ue=hómecátē-sésketv, wine-cup, or glass.

Ue-hómē-eskekó, temperance man.

Uehóme-eskewíketv, s., to be temperate, to quit drink.

Uehóme-eskē-wikv'ketv, p., to stop drink.

Uehómē-es'kv, whiskey drinker, a drunkard.

Ue-hv'ssē, pond, lake, i. e., lost water.

Uehv'tkv, the sea or lake, ocean.

Uehv'tkv-ohfullv'lkē, s a il ors, water people.

Ue-kácv, a water tiger, leopard.

Ueki-uewv, well water.

Uekíwv, spring; cistern, fountain, well.

Ue-kvsv'ppē, cold water.

Uelaúke, flood, high water, gulf. Uelaùkē-rákko, deluge, flood, high water.

Ue-lv'stē, ink, black water.

Ue-lv'stē-vcv'nkv, ink-stand.

Ue-melóhlv, waves, rolling water. Ue-nénē, ditch.

Ue-nénucē, small drain.

Ue-ohfeskv, water sprinkler, Presbyterian.

Ue-ohfeskv'lkē, sprinklers, Presbyterians.

Ue-ohkálv, water pourer, a Methodist.

Ue-óhkalv'lkē, Methodists, waterpourers.

Ue-ohkv'lkv, pouring water.

Ueoh-látkē, falling water.

Ue-ohlátkv, cascade, falls.

Ueoh-látkv-rákko, cataract, big falls.

\section{UEO}

Ue-oh-sóhkat, waterfall.

Ue-ókcvn-cv'mpv, salt water.

Ue-okófkē, muddy water, Mississippi.

Uepv'ton, a sponge.

Ue-rákko, a river, big water.

Ue-svholwákē, muddy water.

Uetem'pē, near the water.

Uetóksē, vinegar, cider, beer.

Uetv'mke, sounding water, We. tumke.

Ue-vfópkē, shore, coast.

Ue-vholwạkēe, dirty water.

Ue-vlákì, tide, coming water, intermittent spring, Wealakv.

Uewóhkv, roaring or barking water, Wewohkv.

Uéwv, water.

Uéwv-escrnkv, water pail.

Uéwv-lekúthat, a bay.

Uewv-tikē-tetáyē, navigable.

Uewv-svfv'stetv, s., to apply water, baptize.

Uewv-vcekéllē, back water.

Ueyókē, lean, poor.

Ueyokófkē, muddy water, the Mississippi river.

Unkó, not like, different, unlike. $\mathrm{Un}^{\prime} \mathrm{kv}$, as, like, or like it.

\section{$\mathbf{V}$}

Used for short $\mathrm{u}$, as in but, Yvmv, Ekvnv. Same as Vn, Vm, My or Mine.

Vc-áfvcíkēkos, I shall not be happy.

Vcáhnetv, s., pour in, put in, exhort.

Vcákē, dear, costly, valuable.

Vcákeko, cheap, not dear.

Vcáketv, s., to be dear, precious, valuable.

Vcakv'ketv, p., to be dear, valuable.

Vcánetv, s., to pour in, put in. 
VCA

Vcápkē, lengthwise.

Vc-atótvtēn, he that sent me.

Vcáyécē, safe, sacred, sound.

Vcayéceko, unsafe, unsound.

Vcayécetv, s., to keep safely, treat kindly.

Vcayéckv, secure, raised in value.

Vcayēcv'ketv, p., to treat kindly, save, preserve.

$V^{\prime}$ cè, corn.

Vcē-cátē, red corn.

Vcē-cvlv'twè, flint corn.

$V^{\prime}$ cè-enfulótkv, corn meal.

Vcē-entálvpē, ear of corn.

Vcē-hv'tkē, white corn.

Vcē-lánē, yellow corn.

Vcélkv, leech.

Vcēlowv'ckē, green corn, roasting ears.

Vcénv, cedar.

Vcēnvhó, hemlock, cypress.

Vcē-sém-fullótkv, corn mill.

Vcē-suklícv, weevil.

Vcē-tvrókwē, gourd-seed corn.

Vcéwē, tardy.

Vcēwécetv, s., to be tardy.

Vcewecv'ketv, p., to be tardy.

Vecéwusē, so soon, already.

Vceyv'lletv, s., to strive at, to strive.

Vceyvllv'ketv, p., to strive at.

$\mathrm{Vc}$-ófv, in me.

Vcóh, upon me.

Vc-okkóhsétsken,you had washed me.

Vc-ókkosétsket, you washing me.

Vcóklepá, a scorpion.

Vcókronhóyv, a spider-web.

Vcókron-rákko, tarantula.

Vcokron'wv, spider.

Vcopóksetv, s., to surround.

Vcopoksv'ketv, p., to surround.

\section{$\mathrm{VCO}$}

Vcópucē, tack.

Vcópv, a nail.

Vcópv-rákko, a spike, big nail.

Vcúklepá, lizzard, scorpion.

Vcúknv, adze, grubbing-hoe, mattock.

Vcúlē, s., old, aged, stale, an elder.

Vcúlē-máhē, very old.

Vcúletv, s., to get old, be old.

Vcúlkv, age, old.

Vculv'ketv, p., to get old.

Vculv'kè, p., old.

Vcúlvkv'lkē, elders, old people.

Vculv'kusē, quite old, little-old.

Vcupóksetv, s., to surround.

Vcupoksv'ketv, p., to surround.

Vcutóketv, s., to pound at.

Vcutokv'ketv. p., to pound at.

Vcvk-áhletv, s., to follow after.

Vcrkáteko, does not follow.

Vcrkáyen, according to, following.

Vcrkáyen-omvtes, it is according to.

Vcrk-áyetv, s., to follow.

Vcvkcuhécetv, p., to stick in.

Vcrk-elv'kes, stand back.

Vcrkfúlletv, p., to follow.

Vcv'kfullv'lke, p., followers.

Vcvk-hécēpuécetv, s., v. c., to make stick in.

Vcvkhécēpuecv'ketv, p., v. c., to make stick in.

Vcvkhécetv, s., to stick in.

Vcrkhecv'ketv, p., to stick in.

Vcv'kusē, short-legged.

Vcv'k-vhóyetv, du., to follow.

Vcv'k-vpéyetv, p., to follow.

Vc-vlísekos, I shall not be ashamed.

Vcvlv'petv, a tray, kneading trough.

Vcrnákē, mine, my own. 


\section{$\mathrm{VCV}$}

Vcv'netv, s., to pour in.

Vcrnhóyetv, pass., is poured in.

Vcv'nkē, holding, containing.

Vcv'nkv, a vessel to hold water or oil, a vat.

Vcrnv'ketv, p., to pour in.

Vcv'sketv, s., to scalp trees.

Vcv'sketv, a scalp, or a blaze of a tree.

Vcvskv'ketv, p., to scalp trees.

Vcvtóhkvr-háks? will he drive?

Vfástē, doing.

Vfástv, doer, overseer, elder of the church.

Vfek-cákhē, mindful, cautious.

Vfekcákhetv, s., to take care of.

Vfekcákhetv, caution.

Vfékcákhv'ketv, p., to take care of.

Vfékhónnetv, s., to rest, endure.

Vfék-honnícit, v. c., causing myself to rest.

Vfékhonnicetv, s., v. c., cause to rest, retain.

Vféklúmketvi, s., to lie on one side.

Vféklúmkv'ketv, p., to lie on one side.

Vfekrákkē, faithful.

Vfekrákketv, s., to trust, depend on.

Vfekrakkv'ketv, p., to trust, depend on.

Vfén'ca, a hornet.

Vfésetv, s., to strip off bark, etc.

Vfēsv'ketv, p., to strip off bark, etc.

Vféyetv, s., to anoint.

Vfēyv'ketv, p., to anoint.

Vfóklotécetv, s., to go around.

Vfóklotecv'ketv, p., to go around. Vfóklótketv, s., to go round any thing.

Vfopécetv, s., to go along side.

\section{VFO}

Vfopēcv'ketv, p., to go along side.

Vfópkē, the brink, edge, shore.

Vfósho, red-elm.

Vfóswv, brush, a bush.

Vfoyv'knetv, s., to be a little one side.

Vfoyv'knusē, a little one side.

Vfoyv'knv'ketv, p., to be a little one side.

Vfúlletv, p., to frequent, to go near some place.

Vfúlotecícetv, v. c., s., to cut around, circumcise.

Vfúlotēcicv'ketv, p.,to cut around, circumcise.

Vfulóthuécetv, s., to drive around.

Vfulóthuecv'ketv, p., to drive around.

Vfulótkē, around.

Vtulótke-ócetv, s., to place it around.

Vfulótketv, s., to go around.

Vfulotkv'ketv, p., to go around.

Vfuscuk-cúrkv, loom harness.

Vfus hérv, silk thread.

Vfúshonv'kē, twisted thread, twine.

Vfús-lepákfv, wahu tree.

Vfúswv, thread, string.

Vfúswvnv'kē, skein thread.

Vfúswv-vpvllákv, spool thread.

Vfus-yékcv, flax thread.

Vfvlè, poured in.

Vfvlékne, out of the way.

Vfvléknusé, little out of the way.

Vfv'lletv, s., to throw at.

Vfvllv'ketv, p., to throw at.

Vfv'nketv, s., to kiss.

Vfvnkv'ketv, p., to kiss.

Vfunnáketv, s., to look about, look up.

Vfvnnakv'ketv, p., to look about, to look up. 


\section{VFV}

Vfvstepuécetv, V. c., to make attend to.

Vfrstepuecr'ketv, p., to make attend to.

Vfv'stetv, s., to attend to, take care of, to govern.

Vfvstv'ketv, p., to attend to, govern, take care of.

Vfv'tcetv, s., to meet, come across.

Vfvtcv'ketv, p., to meet, to come across.

Vifv'tcv, towards, against.

Vfv'tcv-tayet, orthodox, being correct.

Vhákē, an image, likeness, picture.

Vhákv, law, rule, comınandment.:

Vhákv-háyv, law-maker, legislator.

Vhákv-pálat, the moral law, ten commandments.

Vhákvtóko, ünlawful, not the law.

Vhássan, s., old, worn out.

Vhássvkē, p., old, worn out.

Vháyetvn, an example.

Vháyv, a hypocrite, pretender, imitator.

Vhayv'lkē, hypocrites, imitators.

Vhēpvkákvres, will be rejected.

Vhēpv'ketv, s., to push, reject, despise, resist.

Vhēpvkv'ketv, p., to push, reject, despise, resist.

Vhérē, better.

Vhērícē, careful, special, safely.

Vherícetv, s., to fix, improve, trim.

Vhericv'ketv, p., to fix, to trim, improve.

Vhērusē, little better.

Vhesáketv, support, living.

Vhesáketv, s., to live, have life.

Vhesákvkē-táyè, can live.

Vhesákv'ketv, p., to live, save.

\section{VHE}

Vhesákvres, will live, shall be saved.

Vhētécetv, s., to set fire to, to burn.

Vhetecv'ketv, p., to set fire to, to burn.

Vhétkvkē, burning.

Vh'kopv'netv, s., to play, to dance

Vh'kopv'nkv, a play, dance.

Vh'kopvnv'ketv, p., to play, to dance.

Vhlvpátetv, s., to be satisfied.

Vh'lvpv'tketv, p., to be satisfied.

Vhocéfetv, s., to name after.

Vhocéf kē, named after.

Vhocefv'ketv, p., to name after.

Vhócetv, s., to plant.

Vhoc'ke, planted.

Vhóckekón, not planted.

Vhoc'kv, a plant.

Vhóckv'keko, p., not planted.

Vhoc'kvtet, has been planted.

Vhócv, a planter.

Vhocv'ketv, p., to plant.

Vhofúnē, for a long time.

Vhólocēe, a cloud.

Vhólocē-okholáttē, a blue cloud.

Vholócetv, s., to cloud up.

Vhólocv'ketv, p., to cloud up.

Vhólvcēh-pétskvs, thou shalt not covet.

Vhólvcépetv, s., to covet, envy.

Vhólvcēpv'ketv, p., to covet, envy.

Vholv'cetv, s., to covet.

Vholv'ckv, envy, covetousness.

Vholvcr'ketv, p., to covet, envy. Vhólwahókē, p., bad, filthy, dirty.

Vhólwahuécetv, p., to make dirty, pollute, soil.

Vholwákē, s., filthy.

Vhólwayécetv, s., to pollute, soil.

Vhólwayéckv, pollution.

Vhólwayēcv'ketv, p., to pollute. 


\section{$\mathrm{VHO}$}

Vhonécē, awake.

Vhonécetv, s., to awaken, wake up.

Vhonēcícetv, v. c., s., to awaken, cause to awake.

Vhonēcicv'ketv, p., v. c., to awake, cause to awake.

Vhonēcr'ketv, p., to awake.

Vhonkv'tetv, s., to count, numerate.

Vhonkv'tketv, p., to count, to number.

Vhónkv'tkv, the sum, the number. Vhonkv'tkv-háyetv, s, to cipher.

Vhonkv'tkv-hayv'ketv, p., to cipher, count.

Vhúnkvtetv, s., to count, enumerate.

Vhonkvtv'ketv, p., to count, enumerate.

Vhon'tetv, s., to sprout, grow up.

Vhóntusát, a cion, sprout.

Vhontv'ketv, p., to sprout.

Vhopáketv, s., to measure, in length.

Vhopákucē, an inch.

Vhopákv, measure in length, a yard.

Vhopáyetv, s., to measure.

Vhopayv'ketv, p., to measure.

Vhopoyákvtes, they sought.

Vhopv'né, spoils, treasures.

Vhopv'neko, harmless.

Vhopv'netv, s., to spoil.

Vhopv'nkákat, rust.

Vhopv'nke, spoiled.

Vhopv'nkeko, sincerely, not in vain, not spoiled.

Vhopv'nketv, s., to spoil, destroy. Vhopv'nketv, desolation, destruction.

Vhopvnv'hkekos, they will not spoil.

Vhopvnv'ketv, p., to spoil.

\section{$\mathrm{VHO}$}

Vhóretv, s., to sew.

Vhorhuécetv, s., to sew.

Vhórhuecv'ketv, p., to sew.

Vhor'ke, sewed.

Vhor'kv, article to be sewed.

Vhor'kvkē, p., sewed.

Vhor'v, sewer, tailor.

Vhorv'ketv, p., to sew.

Vhosecícetv, s., to leave a part.

Vhosēcicv'ketv, p., to leave things.

Vhóske, remainder, what is left.

Vhos'ketv, s., to leave apart, to remain.

Vhos'kvkē, p., remainders, fragments.

Vhoskv'ketv, p., to remain, to leave a part.

Vhos'wucē, shrub, bush.

Vhos'wv, s., bush, shrub.

Vhot'ce, writing, something written.

Vhot'cetv, s., to write, to make marks.

Vhótcv'ketv, p., to write, make marks.

Vhoyet, du., we two going.

Vhóyetv, du., to go on journey.

Vhóyēyè, du., we both going.

Vhuerv, a debtor.

Vhvlv'tetv, s., to stretch out.

Vhvlv thícetv, s., to stretch out.

Vhvlvthicv'ketv, p., to stretch out.

Vhrlvtv'ketv, p., to stretch.

Vhvm'kv, once.

Vhwátsken, p., you coming.

Vkácat, a fork of water.

Vkácv, thistle.

Vkas'etv, s., to scrape, shave.

Vkáskē, shaved.

Vkas'sē, reduced by subtraction.

Vkassécetv, s., to lessen, reduce.

Vkassēcv'ketv, p., to lessen, reduce by subtraction. 


\section{VKA}

Vkasv'ketv, p., to shave, to scrape.

Vkécē, a large rat.

Vkéfetv, s., to turn up, make bare, to stool.

Vkefikē, turned up dress.

Vkef képetv, s., to turn up dress, stool.

Vkefv'ketv, p., to turn up dress, to stool.

Vkerkúecēpuécetv, v. c., s., to mark.

Vkerkúecēpuecv'ketv, p., v. c., to mark.

Vkérkuécetv, s., to mark, measure, witness.

Vkérkuecv'ketv, p., to mark, witness.

Vker'kv, a mark, mile, measure.

Vkérkvkuécetv, s., to mark, measure.

Vkérkv-kuécvketv, p., to mark, measure.

Vkérkv-rákko, a gallon, bushel.

Vker'kv-rákko-ennvrkv'pv, a half bushel.

Vker'kv-rákko-ennvr'kvpv-ennvr'• kvpv, a peck.

Vkerkv-tutcénen, a league, three miles.

Vker'rē, deceitful, cunning, subtile.

Vker'retv, s., to deceive, be cunning.

Vkerríce-hérē, mindful, very cunning.

Vkerrícetv, s., to think, be thoughtful.

Vkerric'kv, thought, mind.

Vkerríckv-ētícetv, s., to change thoughts, repent.

Vkerríc-èticv'ketv, p., to change thoughts, repent.

Vkerricv'ketv, p., to think, be thoughtful.
VKE

Vkerrícv, thinker.

Vkerrícv-rákkē, magnanimous.

Vkerríyet, having deceived.

Vkerrv, s., deceiver, cheat, witness.

Vkerrv'ketv, p., to deceive, cheat.

Vkerrv'lkē, p., witnesses, cheats, deceivers.

Vketécē, mindful, prudent, vigi. lent.

Vketécetv, s., to watch, observe, examine.

Vketēc'kv, p., a watch, a guard. Vketécv, s., watchman, a watch, a guard.

Vketēcv'ketv, p., to watch, examine, guard.

Vketēcv'lkē, watchmen.

Vkhóthókē, p., shut.

Vkhóthóketv, p., to shut.

Vkhóthuécetv, s., to shut.

Vkhótkē, shut.

Vkhótketv, s., to be shut.

Vkhottetv, s., to shut.

Vkhottv'ketv, p., to shut.

Vkoláswv, a star.

Vkóna-vlkē, extortioners.

Vk-onv'hetv, s., to take from, purloin.

Vk-onvhv'ketv, p., to take from, purloin.

Vk-rófetv, s, to scald.

Vk-rofhóyetv, du., to scald.

Vk-rófv, a scald.

Vk-rof-v'ketv, p., to scald.

Vk-táyetv, s., to drain, strain out.

Vk-tontuécetv, v. C., s., to beat off, fan as hominy.

Vktontuecv'ketv, v. c., p., to beat off, fan as hominy.

Vktonv'ketv, p., to beat off as hominy.

Vkúlhē, an Isthmus, a neck of land. 


\section{VKU}

Vkúlhē-uéwv-lekúthē, a basin, a pond.

Vkululuécetv, s., to enclose.

Vkululuecv'ketv, p., to enclose. Vkululúkē, s.. around, enclosed. Vkululúlvkè, p.. around, enclosed. Vkúsvécē, humbly begging.

Vkúsvpécetv, s., v. c., to cause to beg.

Vkusvpécv'ketv, p., v c., to cause to beg.

Vkusv'petv, s., to beg.

Vkusvpv'ketv, p., to beg.

Vkv'cé, a branch or fork of water. Vkvcēh-lícetv, p., to break

against.

Vkv'cetv, s., to break against.

Vkvcéyetv, p., to break against. Vkvcēyv'ketv, p.,to break against. Vkvláswv, a star.

Vkv'letv, s., to throw against things, as water.

Vkvlkícetv, s., to throw against anything, as water.

Vkvlkicv'ketv, p., to throw against anything, as water.

Vkvlv'ketv, p., to throw against

it, as water.

Vkvlvlálvkē, p.. steep.

Vkvlvlv'kē, s., a bank, steep place.

Vkvlv-lv'kē, s., steep.

Vkv'nsvwécetv, V. c., s., to tire, be weary.

Vkv'nsvwēcv'ketv, p., to tire, be weary.

Vk-vpóyetv, p., to put down in. Vk-vpv'ketv, s., to be within. Vkv'rkvpécetv, v. c., p., to dry up.

Vkvrkv'petv, p., to be dried up. Vkv'rpécetv, s., v. c., to make dry up.

Vkv'rpetv, s., to dry up.

\section{$\mathrm{VKV}$}

Vkv'stetv, s., to observe.

Vkvsv'ppē, moderately cool, coolish.

Vkvsv'ppuécetv, v. c., s., to cool, make cool.

Vkvsv'ppuecv'ketv, p., v. c., to cool, make cool.

Vk.wánv, willow.

Vk-wēnahákusē, wiggle-tail.

Vk-wihóketv, du., to be cast into, throw away.

Vk-wíketv, s., to cast into, throw away.

Vk-wikv'ketv, p., to cast into.

$V^{\prime} l a$, buckeye.

Vlahóketv, du., to come.

Vláketv, s., to come. Yicetv.

Vlákv, a comer.

Vlécē, fast, swift.

Vléceko, not fast, or swift.

Vlēcícē, s., fast handed.

Vlēcícetv, s., v. c., to cause to go fast.

Vlēcicv'kē, p., fast handed, swift. Vlēcicv'ketv, p., to make go fast. Vlécv, swiftness, rapidity.

Vlékcetv, s., to doctor.

Vlek'cv, doctor, physician.

Vlekcv'ketv, p., to doctor.

Vlekúthe, warm.

Vlekúthetv, s., to get warm, be warm.

Vlekuthv'ketv, p., to get warm.

Vlek'wē, s., dissolved, melted.

Vlekwícetv, s., to enrich by dissolving, to dissolve.

Vlekwih'cvrs, manure it, enrich by dissolving.

Vlekwv'kē, p., dissolved, melted. Vles'kè, ashamed.

Vléske-hahícetv, p., to abash, to make ashamed.

Vleske-háyetv, s., to abash, make ashamed. 


\section{VLE}

Vles'ketv, shame, disgrace, filthy. Vles'ketv, s., to be ashamed, disgrace.

Vleskuécetv, v.c., s., to disgrace, make ashamed.

Vleskv'ketv, p., to disgrace.

Vleskvkuécetv, p., v. c., to disgrace.

Vleskv'petv, s., to envy, covet.

Vleskv'pkv, covetousness, envy.

Vleskvpv'ketv, p., to covet, envy.

Vletecícetv, s., v. c., to make run towards.

Vletecicv'ketv, p., to make run towards.

Vlicécetv, s., to begin, to provoke.

Vlicécvtē, the beginning

Vlicéckv, beginning.

Vlicecv'ketv, p., to begin, to urge, provoke.

Vlícetv, s., to begin, to put to, sign a name.

Vlike, sticking to, as wax, also sitting to or by.

Vlikè-áyetv, to go sitting by.

Vlíketv, s., to sit by a person or thing, to sit down.

Vlikē-vhóyetv, du., to go sitting by.

Vlikē-vpéyetv, p., to go sitting by.

Vlikv'kē, p., sticking to, as wax. Vlikv'ketv, p., to sit by a person or thing.

Vlilákat, possessed, sitting on.

Vl'kan, public, in, among.

Vlkáten, among.

Vl'kē, each.

Vl'ketv, s., to be separated, singled out.

Vlófetv, s., to plaster, to daub.

Vlofkē, daubed, plastered.

Vlof kv'kè, p., daubed, plastered.

\section{VLO}

Vlofkv'ketv, p., to daub, plaster. Vlofluécetv, s., to daub, plaster. Vlofluecv'ketv, p., to plaster, daub.

Vloklopícetv, s., to stick to it.

Vloklopicv'ketv, p., to stick to it. Vlókp è, sticking to, adhering. Vlókpetv, s., to stick to, clog. Vlokpícetv, v. c., s., to stick to. Vlokpicv'ketv, p., to stick to. Vlokpv'kè, p., sticking to.

Vlokpv'ketv, p., to stick to, to clog.

Vlonéskē, devil's shoe-string, a weed used for poisoning fish.

Vloso, rice.

Vlos'tetv, s., to favor, think highly of.

Vlostícetv, s., to delight in.

Vlostv'ketv, p., to favor, think highly of.

Vlsē, modest, bashful.

Vl'sekó, not modest, not bashful.

Vls'tetv, s., to shame, be ashamed of.

Vl'sosē, little ashamed, modest.

Vlsv'kē, p., bashful, modest.

Vlsv'ketv, p., to be ashamed, bashful.

Vlsv'kusē, p., little bashful.

Vlum'hē, sticking to.

Vlum'hetv, s., to lay along side, to stick to.

Vlumhícetv, v. c., s., to put anything to, sign a name.

Vlumhicv'ketv, p., to put to, sign a name.

Vlumhv'kè, p., sticking to.

Vlumhv'ketv, p., to be put to, stick to.

Vlun-áha, wild potatoes.

Vlun'wv, a hunt of several days.

V'lv, buckeye.

Vlv'cè, s., linked, fastened. 


\section{VLV}

Vlvcv'kē, p., linked together, fastened.

Vlv'ketv, s., to come. Vlahoketv. Yicetv.

Vlv'skē, s., hurt over again.

Vlv'skvkēe, p., hurt over again.

Vlvs'setv, s., to hurt over again.

Vlvssv'ketv, p., to hurt over again.

Vlv'tketv, S., to fall from a place. $\mathrm{Vm}, \mathrm{my}, \mathrm{me}$, same as $\mathrm{V}, \mathrm{Vn}$.

$V m^{\prime} e$, me, ny or mine.

$V m^{\prime} e t v$, s., to give me.

Vm-hóyēs, pass., is given me.

Vm-mv'ttetv, s., to sin, to err, mistake.

Vm-mv'ttis, I missed it, I am sinning, doing wrong.

Vm-mvttv'ketv, p., to sin, mistake.

Vmómvkes, is expedient.

Vm-óreko, not enough for me.

Vm-osúswv, my grand son, or grand daughter.

Vm-pv'lsē, my mate, companion, relation.

Vmuntv'lkit, I am overcome.

Vm-vhuérē, my debt, indebtedness.

Vm-v'ketv, p., to give me.

$\mathrm{Vn}$, my or mine, same as $\mathrm{Vm}$ or $T$.

Vnáhetv, s., to be destitute, to be in want.

Vnáhet, all gone, all done.

Vnakv'ketv, p., to be destitute.

Vnakuécetv, S., to come or draw near to.

Vnakuecv'ketv, p., to come or draw near.

Vnákv, near, nigh to, about, by them, at.

Vnákvn, near, in the midst, by him.

\section{VNA}

Vnákv-ócetv, s., to put near.

Vnákv-ocv'ketv, p., to put near.

Vnaórketv, s., to sin against me.

Vnatóketv, a joke.

Vnatóketv, s., to joke.

Vnatokv'ketv, p., to joke.

Vnáttat, the wounded, maimed.

Vnáttetv, s., to be wounded, maimed.

Vnē, I, myself.

Vnén, me.

Vnhéssē, friend, my friend.

Vn-hohíkēn, he calling me.

Vnícetv, s., to help, assist.

Vníckv, help, assistance.

Vnícv, helper, assistant.

Vnicv'ketv, p., to help, assist.

Vnokécetv, s., to love.

Vnokéckē, s., beloved, loved.

Vnokéckv, love, charity.

Vnokēckv'kē, p., beloved.

Vnokēcv'ketv, p., to love.

Vnóksē, greedy, gluttonous.

Vnoksétv, greediness, to be a glutton.

Vnóksetv, s., to be greedy, to be a glutton.

Vnoksv'ketv, p., to be greedy.

Vnórv, loaves, loaf, as of bread.

Vnráhpet, having met,or meeting, upposing.

Vnrápē, against, meeting him, opposing.

Vnrapét, going against, opposing, meeting.

Vnrápetv, s., to meet, be against, chide, offend.

Vnrapísem, though he oppose me.

Vnrápkv, temptation.

Vnrapuécetv, v.c., s., to make opposition.

Vnrapúeckv, accusation.

Vnrápuecr'ketv, v.c., p., to make opposition. 


\section{VNR}

Vnrápv, opponent, enemy, adversary.

Vnrajv'kè, p., against it, opposite, meetıng.

Vnrápv'ketv, p., to go against, to meet or be against.

Vnráwv, a desert place, without inhabitants.

Vnsápokau, also my burden.

Vntólo, Andrew.

Vn'tos, I suppose so, I guess so. Vntskómet, independent, obstinate.

Vntv'lket, I myself, I alone.

Vn-tvnómat, as for me.

Vnvcomè, many, plenty.

Vnvcómekó, not many, few.

Vnvcómē-máhē, very many.

Vnv'ttē, wounded, lame, offended.

Vnvttécetv, s. to wound, hinder, offend, etc.

Vnvttécv, an offender, stumbling block

Vnvttecv'ketv, p., to wound, offend.

Vnvttecv'lkē, wounders, offenders

Vnv'ttetv, s., to be wounded, maimed.

Vnvttv'kè, p., wounded, lame, offensive.

Vnvttv'ketv, p., to be wounded.

Vnvtv'ksetv, s., to gaze upward.

Vnvtv'snv'ketv, p., to look up.

Vpácetv, s., to shield, ward off.

Vpákat, every, each.

Vpáken, together, with, immediately.

Vpáket, being with, being in.

Vpáketv, s., to be with, to accompany.

Vpáksè, to-morrow.

Vpákusen, immediately.

Vpalhv'mken, the half, or other part.

\section{VPA}

Vpástvle, an apostle.

Vpáyekot, shall not receive or go with.

Vpáyetv, s., to receive, go with, to leave.

Vpáyvkat, receiving, not going with.

Vpayv'ketv, p., to receive, to go with.

Vpè, a stalk, stock, handle.

Vpefatecícetv, s., v. c., to make run towards.

Vpefátecicv'ketv, p., v. c., to make run towards.

Vpefátketv, s., to run towards.

Vpefatkv'ketv, p., to run towards.

Vpéletv, s., Vpelhóyetv, du., Vpelv'ketv, p., to laugh.

Vpelicetv, s., v. c., to make laugh, deride.

Vpelíckv, laughing stock.

Vpelicv'ketv, p., v. c., to deride.

Vpélkv, laughter, a laugh.

Vpélkvháyv, a jester.

Vpēlúsetv, s., to smile, to laugh.

Vpēlúsv, a smile, a laugh.

Vpēlv, a laugher.

Vpelv'ketv, p., to laugh.

Vpésē, fleshy.

Vpes'ketv, s., to lean back.

Vpeskv'ketv, p., to lean back.

Vpéspvsátkv, slaughter.

Vpéswē, fleshy.

Vpéswr, flesh, meat.

Vpéttē, shade, shed, roof, shady.

Vpéttetv, s., to shade.

Vpettícetv, V. c., to make it shady.

Vpéttusē, little-shady.

Vpéyetv, p., to go.

Vpeyv'ketv, p., to go.

Vpíkē, in, within.

Vpíketv. s., to put in, to be in.

Vpíkv, one that puts in. 


\section{VPI}

Vpikv'ketv, p., to put in.

Vpóhetv, s., to ask, beg, to question.

Vpóhetv, a question.

Vpóhv, beggar, petitioner.

Vpóketv, p., to sit duwn, to dwell. Vpoketv, a den, dwelling place.

Vpókhē, a bunch on anything.

V.pókpóhē, p., bunches on anything, flag.

Vpókpotícetv, p., to lay them alongside.

Vpoktícetv, s., v. c., to lay it by side of.

Vpópuécetv, V. c., s., to place them.

Vpopuecv'ketv, p., v. c., to place them.

Vpoyáketv, p., to put down, place, set aside.

Vpóyetv, s., to keep, put down, place, set aside.

Vpuécetv, to dream, have a vision.

Vpuéckv, a dream.

Vpuecv'ketv, p., to dream.

Vpuékv, tame, or domestic animals, herd of tame animals.

Vpuékv-enfúlletv, a pasture.

Vpúlketv, s. to lie with.

Vpulkv'ketv, p., to lie with.

Vpúlo, a careless weed.

Vpvkáketv, p., to be with, joined to, added to.

Vpvkár-háks? shall I dwell with him?

$V p v^{\prime} k \bar{e}$, with, among. of.

Vpv'ke-háketv, s., to associate with.

Vpv'kē-hakv'ketv, p., to associate with.

Vpvkékat, not together with, separate.

Vpv'ketv, s., to be with, to add.
VPV

Vpvkv'ketv, p., to be with, to add. Vpvitákē, p. of $\mathrm{Vpv}^{\prime} l w v$, others. Vpv'lwv, the remainder, the other, some, certain, reward.

Vpv'lwvset, a part of anything.

Vpv'setv, s., to parch corn, or any thing.

Vpv'skè, s., parched.

Vpvskv'kè, p., parched.

Vpvsv'ketv, p., to parch.

Vpvtv'nv, a bull-frog.

Vpvtv'kv, flat cake, pan cake.

Vputv'tvtvkē, alike, $(i$. e., parallel).

Vprtvtv'kuse, by the sicie of any thing.

Vráhkv, because, instead of, on account of.

Vrahrv'kv, ability.

Vrákkē, s., magnified, enlarged.

Vrákkē, glory, greatness.

Vrákketv, s., to be magnified, exalted.

Vrákkuecáketv, p., to honor, reverence, magnify.

Vrákkuécetv, s., to honor, magnify, celebrate.

Vrákkuéckv, worship, honor, praise.

Vrákkuecv'ketv, p., to honor, magnify.

Vrákkv'kè, p., magnified, enlarged.

Vrakkv'ketv, p., to be magnified

Vrák-rvkuécetv, p., to magnify.

$V^{\prime} k v s-f v^{\prime} k v$, pot hooks.

Vrkvs-háyv, a potter, pot maker.

Vrkv'swv, pot, dirt-pot.

Vrusáyetv, s., to tease.

Vrusayv'ketv, p., to tease.

Vrv'hketv, s., to aim, seek after.

Vrvhkv'ketv, p., to aim, seek after.

Vrvnáhkekos, cannot be hid. 


\section{VRV}

Vrvnákē, out of sight.

Vrvnáken, a secret place, closet.

Vrvnáketv, s., to vanish, get out of sight.

Vrvnákv, a closet.

Vrvnákv'ketv. p., to hide, get out of sight.

Vrvnarícetv, v. c., s., to hide any thing.

Vrvnáyetv, s., v. c., to hide any thing.

Vsánwv, moss.

Vsátetv, s., to make a mark.

Vsatv'ketv, p., to make a mark.

Vséckv, a chase.

Vseháketv, p., to forbid, rebuke, salute.

Vséhetv, s., to forbid, rebuke, to hinder, reprove.

Vséhkē, s., forbidden.

Vséhkv'kē, p., forbidden.

Vsehv'ketr, p., to forbid, rebuke. Vsékē, shaking hands, salutation.

Vséketv, s., to salute, shake hands.

Vsekéyetv, s., to thrust in, many things.

Vsekeyv'ketv, p., to thrust in.

Vsékkēe, engrafted, sticking in a hole.

Vsékketv, s., to graft, engraft.

Vsekséketv, p., to be in a crack, engrafted.

Vsekséyetv, p., to put many things in cracks.

Vsēkv'ketv, p., to shake hands.

Vsenēpécetv, S., to stretch any thing.

Vsenēpecv'ketv, p., to stretch any thing.

Vsenépsécetv, s., to stretch any thing.

Vsenépsēcv'ketv, p., to stretch anything.

Vsímv, beyond, over there.

\section{VSI}

Vsímwv, moss, also mossy.

Vsín, beyond, over there.

Vs'le, erased, rubbed out, gone out.

Vslécetv, v. c., s., to erace, to put out as fire.

Vslecv'ketv, p., to rub out, put out as fire.

$\mathrm{Vs}^{\prime}$-lekon, unquen chable, uneraseable.

Vs'letv, s., to go out, as candle, as fire, put out.

Vslv'ketv, p., to go out, as fire, candle.

Vsóketv, s., to rub against, as hogs do.

Vsókulv, sugar.

Vsokv'ketv, p., to rub against, as hogs do.

Vsóyetv, s., to thrust fast, to stir or scramble anything.

Vsoyv'ketv, p., to thrust fast, to stir anything with sticks.

Vs'sè, tea.

Vsúketv, s., to put in a crack, graft, engraft.

Vsuksúecetv, s., to put in a crack, to graft.

Vsukv'ketv, p., to put in a crack, graft.

Vsúlketv, s., to increase upon it.

Vsúnwv, moss.

V'sv, there.

$V^{\prime} s v$-ófv, therein, in there.

Vsvpvklátet, standing.

Vsvpv'kletv, p., to stand by.

V'ta, a kind of lizzard, groundpuppy.

Vtakhv'kē-lumhicetv, p., to lie by on one's side.

Vtakhv'kē-wakkécetv, s., to lie by on one's side.

Vtakhv'kē-wakhokicetv, du., to lie by on one's side.

Vtákkatícetv, s., to hitch up. 


\section{VTA}

Vtákkaticv'ketv, p., to hitch up. Vtákkáyetv, s., to be hitched up. Vtákkayv'ketv, p., to be hitched up.

Vtak'rv, weeds.

Vtápv, safkey-stirrer.

Vtáretv, s., to hang up, crucify.

Vtarhóyetv, du., to hang up, crucify.

Vtar'kucè, an ounce, little pound.

Vtarkuécetv, s., to weigh, crucify.

Vtarkuecv'ketv, p., to weigh, crucify.

Vtar'kv, a pound weight.

Vtartv'ketv, p., to crucify, to hang up.

Vtáwetv, s., to blame, accuse.

Vtawv'ketv, p., to blame, accuse.

Vtcacícetv, S., v. c., to lean against.

Vtcacicv'ketv, p., v. c., to lean against.

Vtcáketv, s., to be leaned against. Vtcakv'ketv, p., to be leaned against.

Vtcécetv, s., to clothe.

Vtcecv'ketv, p., to clothe.

Vtc'ekon, not clothed, unclothed.

Vtcépetv, s., to clothe.

Vt'cet, clothed, being clothed.

$V t^{\prime}$ cetv, s., to clothe.

Vt'cetv, clothing, blanket.

$V t^{\prime}$ cetv-hérv, broad-cloth.

Vtchóyetv, du., to be clothed.

$V t^{\prime}$ cusv'kè, p., clothing.

Vtcr'ke, clothed.

Vtcv'ketv, p., to clothe.

Vté, since, so, in, from, also, otherwise.

Vtecícetv, s., to commence from. Vtecicv'ketv, p., to commence from.

Vtéhepuécetv, s., to compel them to drive them in.

\section{VTE}

Vtéhepuecv'ketv, p., to make them drive them in.

Vtéhetv, p., to put in, Vpiketv, to put in.

Vtehkákat p., possessed, having within.

Vtéhkepuécetv, v. c., to make enter in.

Vteh'kē-wites, they may be in.

Vteh'ketv, s., to be in, be possessed, inherit.

Vteh'kv, treasure, vessel not holding water.

Vtehkv'ketv, p., to be in, possessed, inherit.

Vtehkv'lke, those within.

Vteh'vrēs, will gather together.

Vtekakátē, p., borders, edges.

Vtékat, s. border, edge, all around.

Vtékat, s., all, every one.

Vtéke, border, all, hem of a garment, vntil.

Vtékis, it was about so.

Vteklikv, borderer.

Vtekót, not come.

Vtékusēe, just as.

Vtelóhyetv, s., to gather together.

Vtelóketv, s., to get together, assemble.

Vtelókv, together, be together, harvest time.

Vtelokv'ketv, p., to get together. Vtelókvte, the flock.

Vteloyetv, s., to gather together, gather up.

Vteloyv'ketv, p., to gather together.

Vtèn, also, from, coming from.

Vteníket, having stuffed in, press down.

Vten'ketv, s., to stuff in, press down.

Vtenkv'ketv, p., to stuff in, press down. 


\section{VTE}

Vtépketv, s., to whip at.

Vtepkv'ketv, p., to whip at.

Vtépvs, come, come on.

Vtétetv, s., to delay, put off.

Vtetv'ketv, p., to delay, put off.

V'tetv, s., Vthoyetv, d., Vwetv, p., to come.

Vthóyetv, d., to come.

Vtófketv, s., to spit on.

Vtof kv'ketv, p., to spit on.

Vtohhóhken, being driven.

Vtóhkē, driven about.

Vtóhketv, s., to drive.

Vtóhkv, driver:

Vtóhkv'ketv, p., to drive.

Vtóklomáketv, s., to slober on.

Vtóklomakv'ketv, p., to slober on.

Vtok'lopē, moss, corn silk.

Vtoklópetv, s., to silk.

Vtoklopvketv, p., to silk.

Vtókor-hué.:etv, du., to make run towards.

Vtothóketv, du., to minister to.

Vtotkákē, ministering to, working for.

Vtótketv, labor, work, minister to.

Vtótketv, s., to labor, to minister to, serve.

Vtótkv, s., a worker, laborer.

Vtotkv'ketv, p., to lubor, minister to.

Vtotkv'lkē, p., workers, laborers.

Vtoyehv'ttē, lightning.

Vtoyēhv'ttetv, s., to lighten.

Vtoyēhvttv'ketv, p., to lighten.

Vtuéwv, a basket, to fan corn with.

Vtúlketv, s., to fall towards.

Vtullóketv, p., to fall towards.

Vtulpóketv, s., to wrap around.

Vtulpokv'ketv, p., to wrap around. $V^{\prime}$ tv, snail.

Vtv'cetv, s., v. c., to stop the running.

\section{VTV}

Vtv'cketv, s., to stop a running. $V t v^{\prime} c k v$, inpediment, stoppage. Vtvckv'ketv, p., to stop a running. Vtvcr'ketv, p., v. c., to stop the running, prevent it.

Vtv'kkaticetv, p., to hitch up.

Vtv'kka-tv'ketv, p., to be caught.

Vtv'kkv'ketv, s., to be caught.

Vtvkkv'yetv, s., to hilch up.

Vtvklécetv, s., to ridicule, blaspheme.

Vtvkléckv, evil speaking, blasphemy.

Vtv'klecvketv p., to ridicule, blaspheme.

Vtv'kletv, s., to be ridiculed, blasphemed.

Vtvklv'ketv, p., to be rídiculed, blasphemed.

Vtv'krv, a weed.

Vtvléksē, spread out.

Vtvléksetv, s., to be spread out, as a hide.

Vtvleksícetv, s., v. c., to spread out as a hide.

Vtvléksicvketv, p., v.c., to spread out as hides.

Vtvléksv'ketv, p., to be spread out.

Vtv'phv, dog-wood.

Vtv'retv, s.. to hang any hing up, crucify, see Vtarketv.

Vtvrhóyetv, du., to hang up, to crucify.

Vtvr'ketv, p., to hang, or weigh, crucify.

Vtvr-táyet $v$, s., to hang up anything, to crucify.

Vtvrtícetv, p., v. c., to cause to hang any thing up.

Vtvrticv'ketv, p., to hang anything up.

Vtvrtv'ketv, p., to hang one's self, to hang on. 


\section{VTV}

Vevrtv'yetv, p., to hang up any thing.

Vwahécetv, S., v. C., to make scatter, to scatter.

Vwahēcv'ketv, v. c., p., to scatter.

Vwáhètv, So, to scatter themselves.

Vwahv'ketv, p., to scatter.

Vwar'et, divided amongst them.

Vwar'etv, s., to divide amungst them.

Vwárof, when he divides among them.

Vwar'v'ketv, p., to divide among them.

Vwèlépkē, s. across, as saddle bags.

Vwēlepkv'kē, p., across, as saddle bags.

Vwēlv'ketv, du., to go about, near, or around.

Vwën, part., coming, having come.

Vwépekvs, let them come.

V'wetv, p., Vtetv, Vthoyetv, to come.

Vwólē, near, not far off.

Vwolícetv, s., to go near.

Vwolícúsekv, for it draws near.

Vwolícv, a neighbor, near.

Vwolicv'ketv, p., to draw near, go near.

Vwólv, neighbor.

Vwóskē, attached to.

Vwósketv, s., to get attached to.

Vwoskuécetv, S., v. c., to make attached to.

Vwoskv'ketv, p., to get attached to.

Vwóskvkuécetv, p., v. c., to make attach to.

Vwótetv, s., to vomit, puke.

Vwotícetv, So, v. c., to make vomit.

\section{VWO}

Vwoticv'ketv, p., v. c., to make vomit.

Vwótkv, vomit, an emetic.

Vwotv'ketv, p., to vomit.

Vwvlv'pécícetv, s., to throw over.

Vwvlv'pēcicv'ketv, p., to throw over.

Vwvlv'phúecetv, s., v. c., to throw over.

Vwvlv'phuecv'ketv, p., v. c., to throw over.

Vwv'nhē, hard packed.

Vwv'nhécetv, s., to pack hard.

Vwv'nhecv'ketv. p., to pack hard.

Vwvn'hetv, s., to be hard packed.

Vwv'nhv'ketv, p., to be hard.

Vyékcē, earnestly, strongly.

Vyékcetv, perseverance.

Vyékcetv, s., to be fastened to.

Vyekcv'ketv, p., to be fastened to.

Vyócetv, s., to pick up.

Vyocv'ketv, p., to pick up.

Vyófetv, s., to heal, to cure.

Vyofv'ketv, p., to heal, to cure.

Vyuláhletv, s., to swing.

Vyuláhlv'ketv, p., to swing.

Vyulásketv, s., to swing.

Vyuláskv'ketv, p., to swing.

Vyvhíketv, s., to sing to.

Vyvhikv'ketv, p., to sing to.

\section{W. \\ As in English.}

Wah'ketv, s., to lament, mourn.

Wah'kolv, a loon, diver duck.

Wahk'vketv, p., to lament, to mourn.

Wahóketv, d., to mourn, lament.

Wahokv'ketv, p., to mourn, lament.

Wahókv, a mourner.

Wahokv'lkē, mourners.

Wahv'llv, the South. 


\section{WAH}

Wahwv'kwv, a large wood cock.

Wákkan, the one lying down.

Wakkécetv, s., v. c., to lay on, make lie down.

Wakkecv'ketv, p., v. c., to make lie down, lay on.

Wákken, lying down.

Wákketv, s., to lie down.

Wakkv'ketv, p., to lie down.

Wakucē, a calf, little cow.

Wákucē-vpéswv, veal.

Wáku-rákko, common blue crane.

Wákv, a cow, cattle.

Wákv-cúlē, an old bull or steer.

Wákv-encv'kotv'ksē, an ox bow.

Wákv-enkáfkv, milk cow.

Wákv-enókwv-mvkvlolókv,

ox bow.

Wakv-hóktē, cow.

Wakv-hoktv'lwv, an old cow.

Wakv-hunv'nwv, a bull.

Wakv-hútē, cow-pen. cow-house.

Wakv-hv'rpē, cow-hide.

Wakv-hv'rpē-cátē, tanned,leather.

Wakv-móh-tvkhákv, ox-yoke.

Wakv-móh-wákkē, yoke of oxen.

Wakv-nehá, tallow.

Wakv-péssē, milk.

Wakv-péssē-cv'mpē, sweet milk.

Wakv-pessē-mv'knehá, rream.

Wakv-péssē-néhá, butter.

Wakv-pessēnēhá-opúswv, buttermilk.

Wakvpessē-tóksē, sour milk.

Wakvpessē-tvklíkē, cheese.

Wakv-vpéswv, beef.

Wakvtého, steer.

Wakvtótkv, work steer, an ox.

Wakv-yvpē, cow-horn.

Walvpécē, coming, a woman's name.

Wapv'ksetv, colic.

Wáretv, p., to cut off.

War'kè, p., cut off, pieces.

\section{WAR}

War'kvkē, p., cut off.

Warkv'ketv, p., to cut off.

Was'ketv, s., to beat, or cut much.

Wásko, chégoē, small red insect.

Waskv'ketv, p., to beat, cut much.

Watúlv, sandhill crane.

We, also, (put at the end of a word, same as ue).

Wealáka, the coming water, as the tide, (from uewv, water and alaka, coming).

Wecárē, sparks.

Wecarécetv, s., to make sparks.

Wécarê-cv'ketv, p., to make sparks.

Wécáretv, s., to sparkle.

Wécarv'ketv, p., to sparkle.

Wècwéyetv, s., to twinkle.

Wécweyr'ketv, p., to twinkle.

Wēhákē, s., wide-mouthed.

Wēhákusē, a little wide-mouthed.

Wehakv'kè, p., wide-mouthed.

Wèhakv'kusēe, p., a little widemouthed.

Wéhénwetv-vtekat, s., to affirm. Wēhénwv, certainly, true.

Wëhenwv'kè, p., certainly, true.

Wèhv'klē, s., wide-mouthed.

Wéhv'klusē, a litule wide-mouthed Wēhv'klvkē, p., wide-mouthed.

Wêhvklv'kusēe, p., a little widemouthed.

Wëkécketv, s., to creak.

Wēkeckv'ketv, p., to creak.

Wēlákēe, du., going about.

Wēláketv, (du. of Aretv) two to go about.

Wélánv, Jerusalem oak.

Wëlatv'kv, tree toad.

Wëleksē, s., wide-mouthed (applied to persons).

Wēléksusē, little wide-mouthed, (applied to persons). 
WEL

Wēleksv'kē, p., wide-mouthed, (applied to persons).

Wëleksv'kusē, p., little widemoushed, (applied to persons).

Wëlépetv, s., to root, as of hogs.

Wèlepv'ketv, p., to root as a hog. Wēnahókē, p., living, living things.

Wēnahókē-lopútskusát, insects, animal-cula.

Wēnahóketv, p.. to live.

Wēnahókucē, insects.

Wenahókuce-estákkē, bites of insects.

Wēnahókusē, p., a little alive, quickened.

Wénahuécetv, s., to make live, quickened.

Wènákē, alive, living.

Wénáketv, s., to live, to come.

Wēnákusē, s., little alive.

Wénetv, s., to take out entrails, to gut.

Wen'hv, forehead, eyebrows.

Wénketv, s.: to be open.

Wen'stē, Wednesday.

Wenv'ketv, p., to take out entrails, to gut.

Wer'hē, s., hanging about carelessly, lounging.

Wërhv'kē, p., hanging about carelessly, lounging.

Wērócké, floppy.

Wēroc'kusē, s., little floppy.

Wērockv'kē, p., floppy.

Wérockv'kusē, p., little floppy.

Wer'rē, hanging loose.

Wésetv, s., to fan, winnow.

Wéskē, s., hanging loose, like long hair.

Wéske, whiskey.

Wèskucē, small lice.

Wes'kv, lice.

Weskv'kē, p., hanging loose.

\section{WES}

Wéso, sassafras.

Wesv'ketv, p., to fan corn.

Wesv'ktē, irregularly, not close.

Wesvktv'kè, p., irregularly, not close.

Wèténetv, s., to squeeze, oppress. Wèténken, overcome, oppressed. Wetenv'ketv, p., to squeeze, op. press.

Wícetv, s., v. c., to heal, make quit.

Wicēcv'ketv, p., v. c., to heal, make quit.

Wíhetv, s., to bear, submit to.

Wih'ketv, s., to quit, heal, leave.

Wih'kvkos, I will not stop or quit.

Wikáhket, leaving, having left.

Wikáketv, p., to betray, submit.

Wiképetv, s., to get well, be heal. ed.

Wíketv, s., to quit, cease, to be healed.

Wíketv, an end, command.

Wikvképetv, p., to heal, to get well, cease, quit.

Wikv'ketv, p., to quit, cease, forsake.

Wikv'kvkos, I do not leave there, Wítes, may, might.

Witéye, lest.

Wíyen, selling.

Wíyetv, s., to sell, to yield, deliver up.

Wíyetvn, an offering.

Wiyē-yvmáhkuécet $v, \mathrm{~s}$., to spend. Wiyē-yvmáhkuecv'ketv, p., to spend.

Wíyo, flying squirrel.

Wíyv, seller, trader.

Wiyvketáyē, saleable.

Wiyv'ketv, p., to sell.

Wocótetv, s., to carve, mow, reap.

Wócutáketv, s., to reap, or cut. 


\section{$\mathrm{WOH}$}

Woh'ketv, s., to bark, as a dog. Wohkv'ketv, p., to bark, as a dog.

Wohóketv, s., to howl.

Wohokv'ketv, p., to howl.

Wokócetv, s., to crumble, break up in pieces.

Wokócke, crumbs.

Wokóckē, s., crumbled.

Wokockv'kè, p., crumbled.

Wólketv, du., to go out, Ossetv, s., Sossetv, p.,

Wósetv, s., to scratch up dirt with claws.

Wosv'ketv, p., to scratch up the dirt with claws.

Wotko, a raccuon.

Wotko-éstē, baboon, a monkey.

Wotko-éstē-rákko, an ape, gorilla.

Wulécetv, s., to take corn out of the mortar.

Wulēcv'ketv, p., to take corn out of the mortar.

Wulhuécetv, du., to furn out, cast out.

Wvcénv, Washington, an American, a Virginian.

Wrcēnv'lke, Americans, i. e., Virginians.

U'vhélv, small boy.

Wvhv'lv, South.

Wv'nawícetv, s., v. c., to tie, to bind.

Wv'náwicv'ketv, p., v. c., to tie, to bind.

Wv'nayáhkof, when they had bound.

Wvnay'etv, s., to bind, to tie. Wv'náyv'ketv, p., to bind, to tie. Wvn'he, hard, firm.

Wvnhecr'ketv, p., to harden.

Wvn'hetv, s., to get hard.

Wvnhícetv, s., v. c., to harden. Wvnh'kákuset, being thirsty.

\section{WVN}

Wvn'hke, thirsty.

Wvn'hketv, s., to be thirsty.

Wvnhkv, thirst.

Wvn'hkv'ketv, p., to get thirsty.

Wvn'wvhē, p., hard, firm.

Wvnwv'hetv, s., to get hard, be firm.

Wvnwv'ketv, p., to crumble, get hard.

Wvpv'ksē, s., swelled, bloated.

Wvpvswv'kē, p., swelled, bloated. Wvsóktē, bushy.

Wvswv'ketv, s., to whisper.

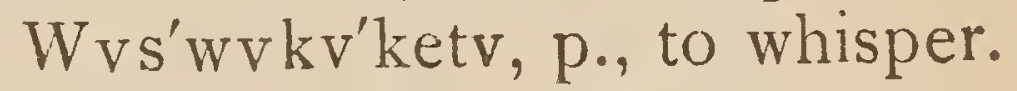

\section{Y.}

As in English.

Yácetv, s., to desire, want.

Yacv'hkekos, they wont want it.

Yacv'ketv, p., to desire, want.

Yáfkē, evening.

Yaf'kes, late, it is late.

Yáf kof, when it is evening.

Yáf kuse, late in the evening.

Yafyv'ke, evenings.

Yafyv'ketv, s., to be getting late.

Yáhketv, s., to shout, hoop.

Yahkv'ketv, p., to shout, whoop.

Yáhv, a wolf.

Yáhv-lánē, a yellow wolf.

Yáhv-lánucē, yellowish wolf.

Yáhv-rákko, a mountain wolf.

Yákpē, forked, crotch.

Yákyv'pē, p., forked, cloven.

Yáyetv, s., to go by. Yvhoyetv, du. Yrpeyetr, p.

$\mathrm{Ye}$, away to.

Yē-crhēcv'nkes, ye visited me.

Yē-fúlketv, s., to go back.

Yëfyéyetv, s., to twinkle, sparkle. Yefyēyv'ketv, p., to twinkle, sparkle.

Ye-hécetv, s., to visit, to come and see. 


\section{YEH}

Ye-hecv'kētv, p., to come and see, to visit.

Ye-hórkopáketos, stole him away.

Yekcakísem, though they are strong.

Yékcēe, strong.

Yekcekó, not strong, weak.

Yekcē-máhē, powerful, very strong.

Yékcetv, strength, power, authority.

Yékcetv, s., to be strong, robust.

Yekcetv-omvlécv, Omnipotence, all powerful.

Yekcē-v totketv, s., to work hard, to toil.

Yekcê-vtotkv'ketv, p., to work hard.

Yekcíce, strong.

Yekcicetv, v. c., s., to streng then, to make strong.

Yekcicv'ketv, p., v. c., to strengthen, compel.

Yekcv'kè, p., strong.

Yekcv'ketv, p., to be strong.

Yekcvkuécetv, v. c., s., to make strong.

Yekcvrkv'swv, brass kettle.

Yekēhsícetv, s, to shock, shake.

Yekēhsicv'ketv, p., to shock, shake.

Yekhócetv, s., to take it by force.

Yékletv, s., to pinch.

Yeklv'ketv, p., to pinch.

Yékote, s., weak in the back.

Yekotv'ke, p., weak in the back.

Yelícetv, s., to bring home.

Ye-monáyetv, s., to come and tell him.

Ye-monayv'ketv, p., to come and tell him.

Yēnaháckē, perverse, crooked.

Yēnahácketv, p., to be perverse, crooked.

\section{YEN}

Yēnáhē, crooked, wavering.

Yénáhetv, s., to be crooked, perverse.

Yēnáh-séko, not perverse, or crooked.

Yènahv'kēe, p., to be crooked, perverse.

Yënahv'ketv, p., to be crooked, perverse.

Yënáyeyē, s., crooked, (as a snake).

Yènayeyv'kē, p., crooked, (as a snake).

Yes-áyetv, s., to go by with.

Yeshvtápketv， s., to divide into two.

Yésketv, s., to come and drink.

Yeskv'ketv, p., to come and drink.

Yesvhóyetv, du., to go by with.

Yesvpéyetv, p., to go by with.

Yètóhkvlkē, together.

Yêtvklatkéckof, when you come and fall.

Yicēs, we come.

Yícetv, p., to come to, Alv'ketv, Vlahóketv.

Yicutes, they came.

Yíyetv, a tumult.

Yíyetv, s., to come by.

Yoc'kē, wrinkled.

Yocóftē, drawn together.

Yocóftetv, s., to draw up.

Yocoftv'ketv, p., to draw up.

Yoh, to.

Yóh-fullēcépetv, s., to depart, return frum.

Yokkóf ketv, shirt.

Yokkóf ketv-hókpē, shirt-bosom, dicky.

Yok'petv, s., to creep upon, steal upon.

Yólketv, s., to suck with the tongue. 


\section{YOL}

Yolkv'ketv, p., to suck with the tongue.

Yoman, in such a way, thus.

Yómat, in such a way, about.

Yómē, so-so.

Yomúckē, dark, darkness.

Yomúcke-ómē, dim, rather dark.

Yomuc'kusē, twilight.

Yomucyókē, p., dim, rather dark.

Yomusíyan, even I am so.

Yopécusē, creeping things.

Yópketv, s., to creep.

Yópkē, creeping, slow.

Yopkusē, rather slow.

Yopkv'ketv, p., to creep.

Yópu-mvtv'khákv, singletree.

Yopúskē, instead of, exchange.

Yopúsketv, s., to exchange, instead of.

Yorécetv, p., v. c., to make fall down.

Yóretv, s., to fall down.

Yórketv, d., Látketv, s., Latkv'ketv, p., to fall down.

Yotécat, thronged, crowded.

Yotécetv, s., to throng.

Yúknè, withered.

Yuknépetv, s., to wither.

Yuknétv, s., to wither.

Yuknícetv, v. c., s., to wither anything.

Yúknicv'ketv, v. c., p., to wither anything.

Yuknv'ketv, p., to wither.

Yukópetv, s., to decrease, reduce.

Yukopícetv, s., to lessen, reduce.

Yukopicv'ketv, p., to reduce, lessen.

Yukopv'ketv, p.,to reduce, lessen, decrease.

Yukpóyetv, s., to finish, make an end.

Yukséhnē, having a cold.

Yukséhnetv, cold, influenza.

\section{YUK}

Yukséhnetv, s., to take a cold.

Yukséhnv'ketv, p., to take a cold.

Yuksícetv, s., to end, make an end.

Yuksicv'ketv, p., to end.

Yúksv, the end, the point.

Yukvlikv, the butt of a gun, $i . e$., thing at the end.

Yulóhē, loose, easy, slack.

Yulóhetv, s., to be loose, easy, slack, slow.

Yulohícetv, s., to loosen.

Yulóhicv'ketv, p., tc !oosen.

Yulóhusen, slow, mild.

Yulohv'ketv, p., to be loose.

Yúpo, the nose.

Yupo-vtárkv, nose ring or jewel. Yupocátv, nose bleeding.

Yupo-haúkē, nostrils.

Yupo-luwákē, an elephant, $i . e$. , limber nose.

Yupo-luwákè-núté, ivory, $i$. $e_{\text {. }}$ the elephant tooth.

Yupo pícetv, s., to halter.

Yupo-picv'ketv, p., to halter.

Yupó-píkv, a halter.

Yúpv, behind.

Yupvklv'tkè, falling behind.

Yupvklv'tketv, s., to fall behind, lag.

Yupv'klvtkv'ketv, p., to fall behind, lag.

Yúpv-likv, the butt of a gun.

Yúpv-vhóyetv, du., to come behind.

Yúpv-vpéyetv, p., to come be. hind.

Yúpv-vpvlv'tetv, s., to cast be. hind.

Yúpv-vpvlvtv'ketv, p., to cast behind.

Yupv.v'tetv, s., to come behind. Yutcv'lkē, Yuchee people, Yuchēē Indians. 


\section{Y VC}

Yvcáketv, s., to chew, champ.

Yvcakv'ketv, p., to chew, champ. Yvfékcv, (contracted) soul, spirit. Yvfv'nketv, s., to get in sight.

Yvhéklè, bushy.

Yvhékletv, s., to be bushy.

Yvheklv'ketv, p., to be bushy.

Yvhih'kv, a blue-bird.

Yvhíkè, musical, singing.

Yvhíketv, a song.

Yvhíketv, s., to sing.

Yvhíketv-hērv, anthem.

Yvhíkv, a singer.

Yvhikv'ketv, p., to sing.

Yvhoyetv, du., to come by, Yáyetv; s., Yvpéyetv, p.

Yv'hucē, a little wolf.

Yvhuéretv, s., to stand by.

Yvkéknetv, s., to riggle.

Yvkéknv'ketv, p., to giggle.

Yv'kpē, forked, a crotch.

Yv'kpetv, s., to be forked.

Yvkvpákē, walking.

Yvkvpáketv, p., to walk.

Yv'kvpē-lopícv, a pacer.

Yvkvpétske-tetayá? can you walk well?

Yvkv'petv, s., to walk.

Yvkvpv'ketv, p., to walk.

Yvkyápv, stakes in the ball play.

Yvkyēpá, tame.

Yv'kyvpē, p., forked.

Yvkyv'petv, s., to be forked.

Yvláhv, a lemon, or orange.

Yvláhv-cvm'pé, an orange, sweet orange.

Yvláhv-tóksē, a lemon, or sour orange.

Yvlúnkv, a root, letter, text.

Yvlun'kv-cátē, beet, raddish.

Yvlúnkv-lánē, sarsaparilla.

Yv'lv, grub-worm.

Yv'lv-rákko, a large worm.

\section{YVM}

Yvmahécetv, s., v. c., to waste, make waste.

Yvmahec'kē, extravagant, wasteful.

Yvmahéckv, a waster, extravagant person.

Yvmahècv'ketv, p., v.c., to waste, make waste.

Yvmahíkekos, is not wasted.

Yvmahíketv, s., to waste.

Yvmáhkē, waste, extravagant, rust, idleriess.

Xvmáhketv, s., to waste, be extravagant.

Yvmáh-kuécetv, v.c., s., to spend, waste.

Yvmáhkuécv, a waster, a prodigal.

Yvmáh-kuecv'ketv, p., v. c., to spend, cause waste.

Yvmáhkúecvlkē, prodigals,spendthrifts.

Yvmáhkv'ketv, p., to waste, destroy.

Yvmah'kv, a prodigal, destroyer.

Yvmimv, this way, on this side.

Yvmin, this way, on this side.

$Y v^{\prime} m v$, here, this place, also $\mathrm{Y}_{\mathrm{vn}}$, $Y v$.

$\mathrm{Yv}_{\mathrm{v}} \mathrm{mv}$-áyat, hence.

Yvmv'sè, gentle, quiet, kind.

Yvmv-sícetv, s., v. c., to tame.

Yvmv-sécetv, s., v. c., to tame.

Yvmv-sécv'ketv, p., v. c., to tame.

Yvmv'setv, s., to be tame, quiet, meek.

Yvmv'sketv, meekness, gentle.

Yvmv'skv, tame, gentle, meekness.

Yv'mvsv'kē, p., tame, gentle, meekness.

$Y_{v}^{\prime}$ mvsv'ketv, p., to be tame, gentle, meek. 
YVM

Yv'mv'svkúehocetv, s., to be tamed, gentled.

Yvn, here, this, also Yvm, Yv.

Yvnáwv, the cheek.

Yvnv'f kè, light.

Yvnv'khv'kv, eaves, eave-bearer.

Yvnv'sucé, young buffalo.

Yvnv'sv, a buffalo.

Yvnv'sv-cúle, old buffalo.

Yvnv'sv-hókté, buffalo-cow.

Yvnv'sv-hoktv'lwv, an old buffalo cow.

Yvnv'sv-hv'cē, buffalo's tail.

Yvnv'sv-hvr'pē, buffalo-robe, or hide.

Yvnv'sv-vpéswv, buffalo-meat.

Yvnv'sv-yv'pē, buffalo-horn.

Yv'pē, horn.

Yvpēfík-éssē, wool, hair of sheep.

Yvpē-fíkucē, lamb, little sheep.

Yvpēfíkv, sheep, i. e., twisted horn.

Yvpefíkv-cúlē, an old ram.

Yvpēfíkv-es'sē, sheep wool, or hair.

\section{YVP}

Yvpēfíkv-ets'kē, a ewe sheep.

Yvpëfikv-hoktv'lwv, an old ewe.

Yvpéf ik-vpéswv, mutton.

Yvpéfv'ské, the stakes in the ball ground.

Yvpe-hv'kkv, horn-spoon.

Yvpéyetv, p., to go by.

Yvsēhóketv, du., to stand by.

Yvsvpv'kletv, p.., to stand by.

Yvtéketv, s., to interpret.

Yv'tekv, interpreter.

Yrtēkv'ketv, 1., to interpret.

Yvtohképetv, s., to come and drive away.

Yvtoh'ketv, s., to come and drive away.

Yvtóhkvképetv, p., to come and drive away.

Yvtóhkv'ketv, p., to come and drive away.

Yvwēyíyetv, s., to beat the air with the hand.

Yvweyiyv'ketv, p., to beat the air with the hand. 

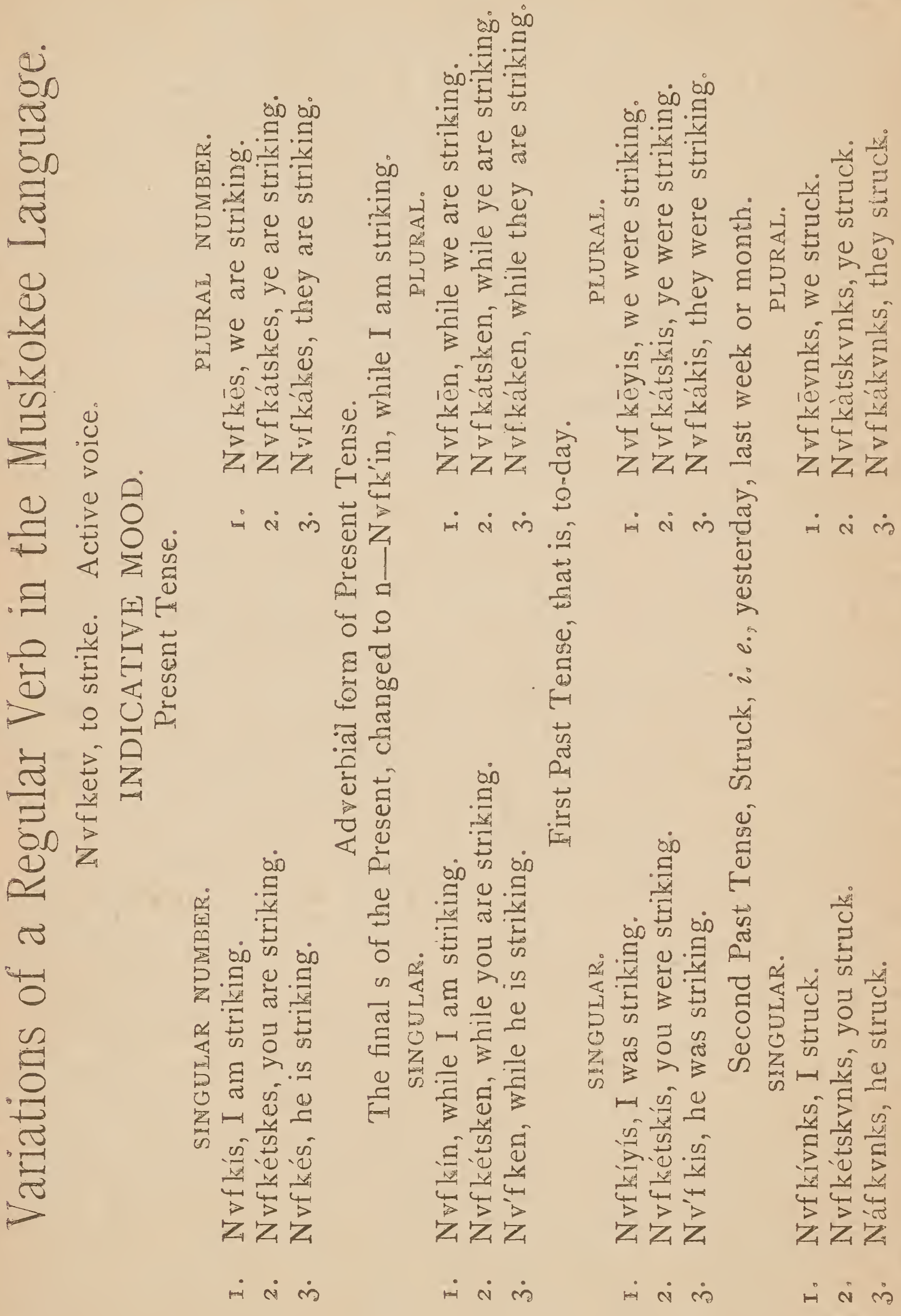
焉焉

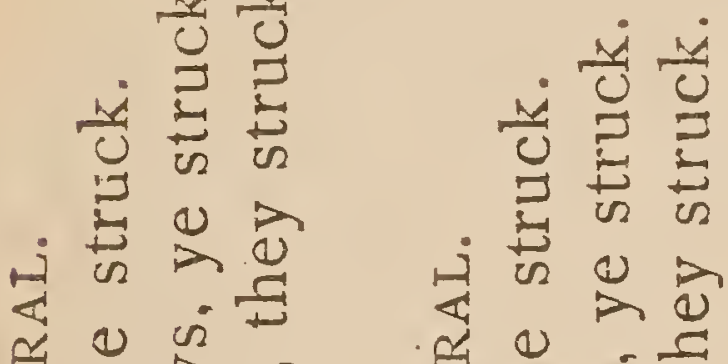

透

० 2 कि

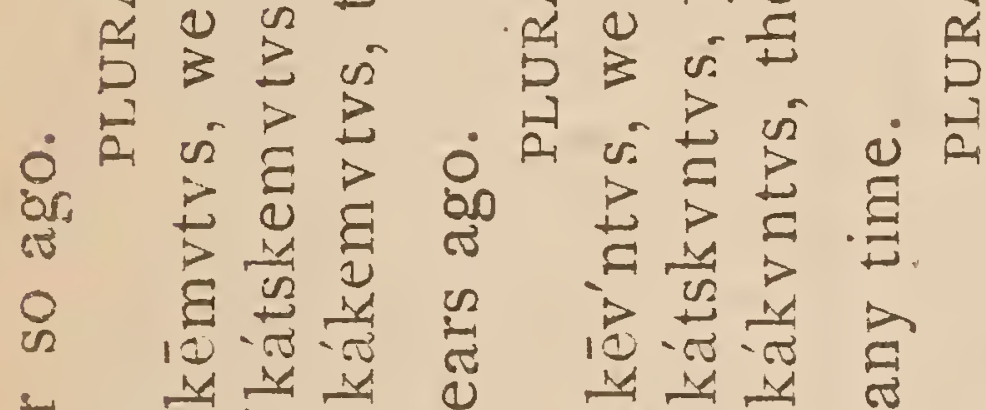

i-

离 ZZZ

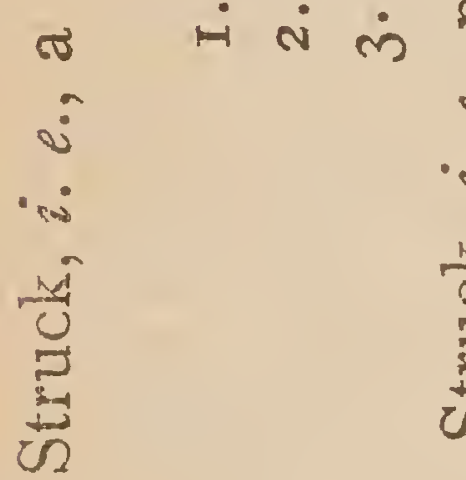

की

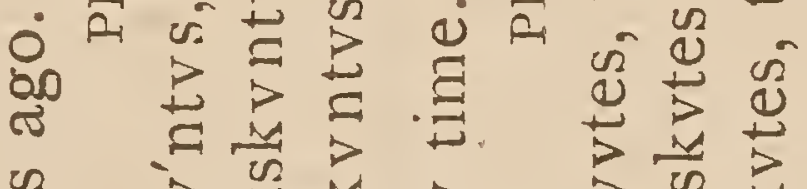

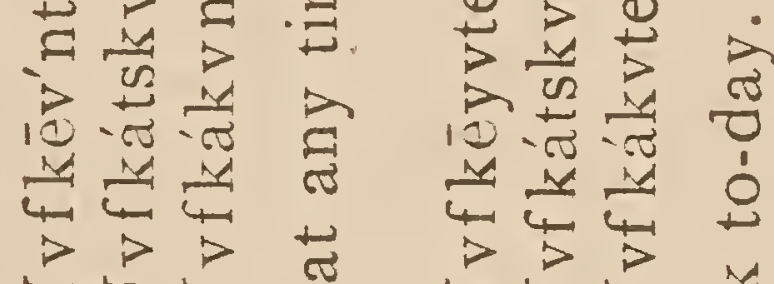

点品品忞学

$\dot{i} \dot{\sim} \dot{n}$

$\dot{\sim} \dot{\sim} \dot{m}$

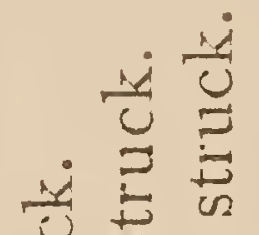

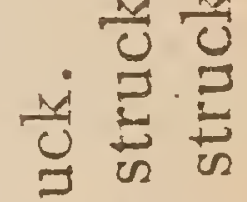

का

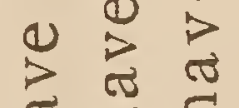

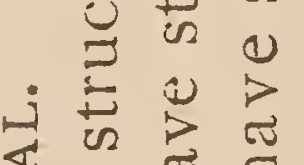

㱐过

西旦

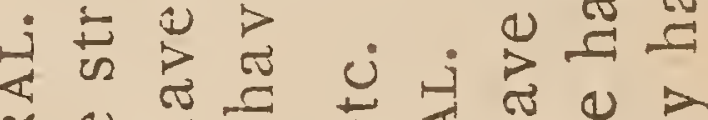

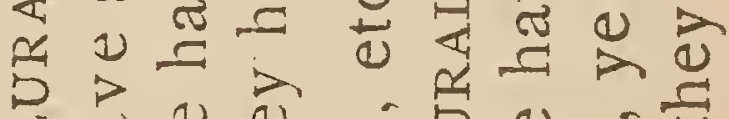

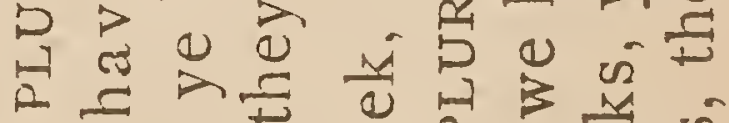
यंग की के की 3 थ

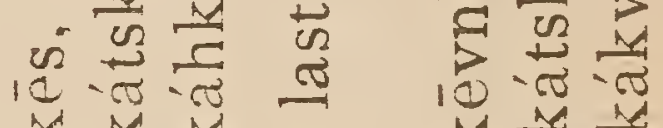

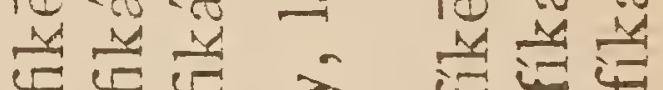

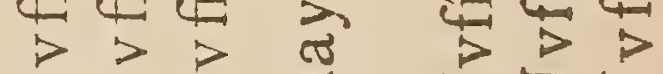
吕号导品品

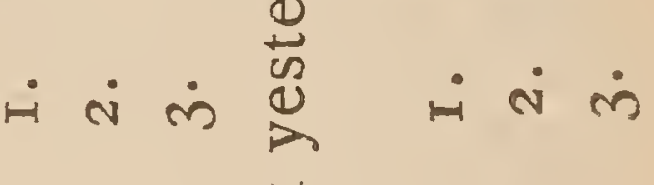

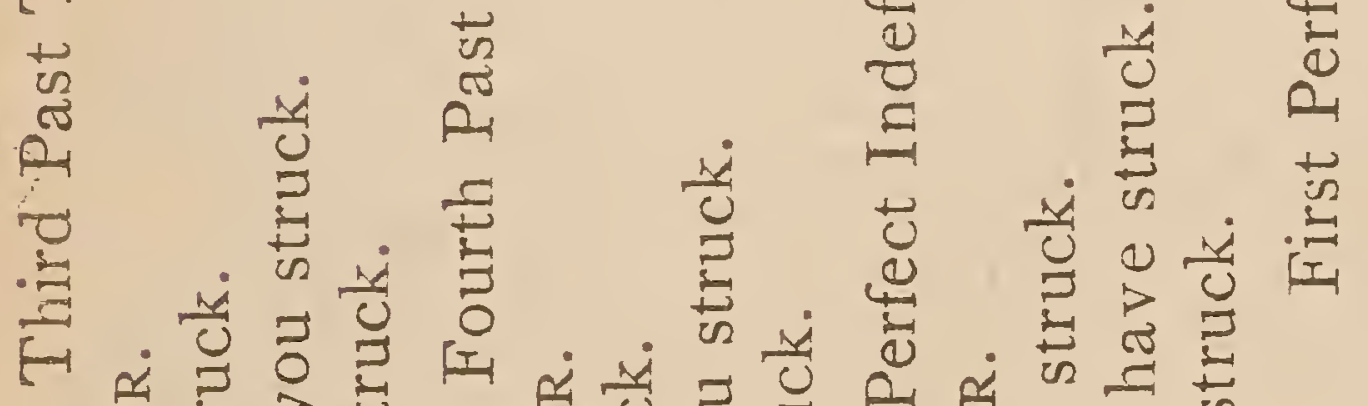

म

蛋

岂

is

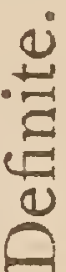

营

(1)

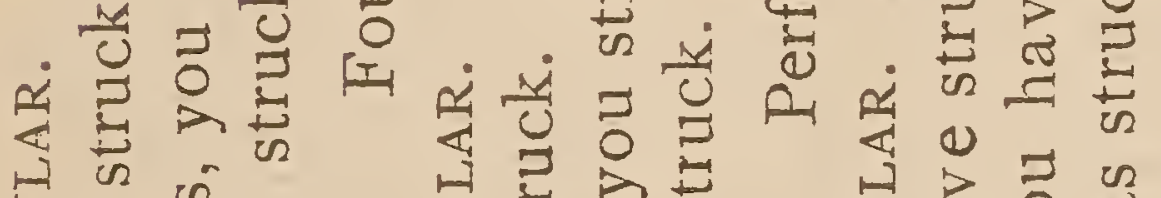

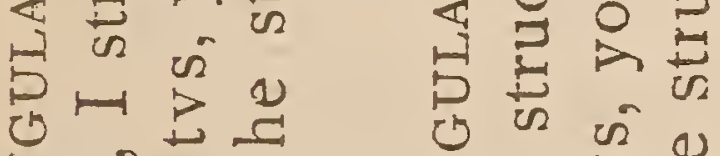
䚄 $\rightarrow$ D

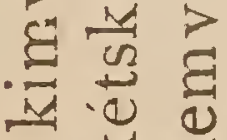
$\because 4$ $\rightarrow 5$. 乙嵒

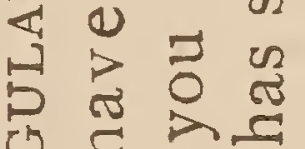
营

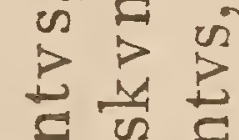
击语 党然 $\sum_{>} 4$ 名安 营 $\mapsto$ 过 की $\frac{1}{3} \frac{2}{2}$

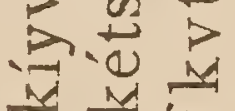
4 Z只要 占

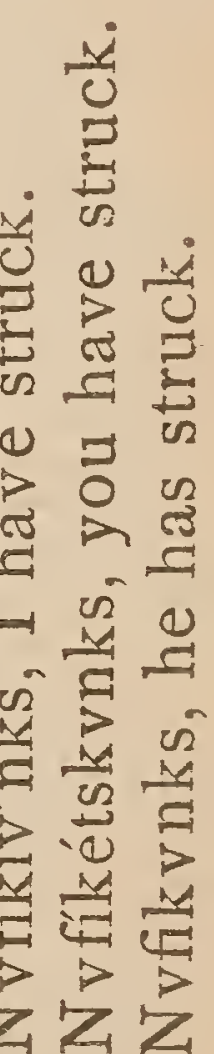

$\dot{\sim} \dot{N} \dot{n}$

$\dot{i} \dot{\sim} \dot{m}$

$\dot{\sim} \dot{\mathrm{n}}$ 西 $>-$

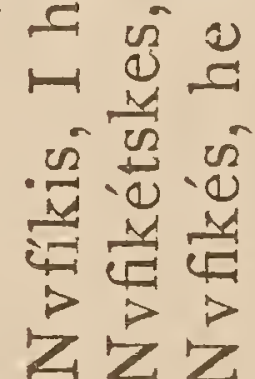

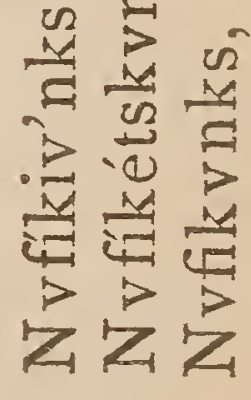




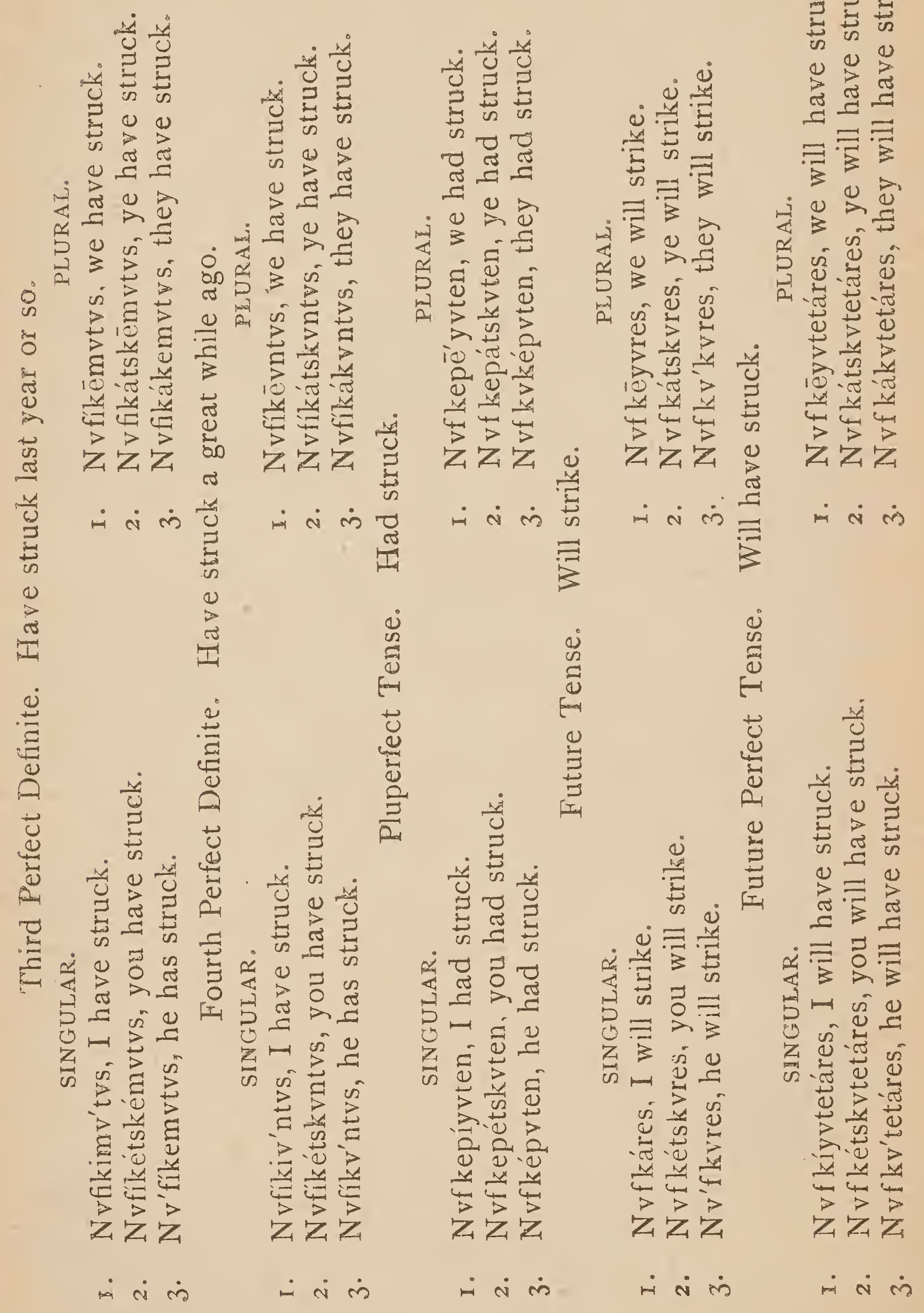




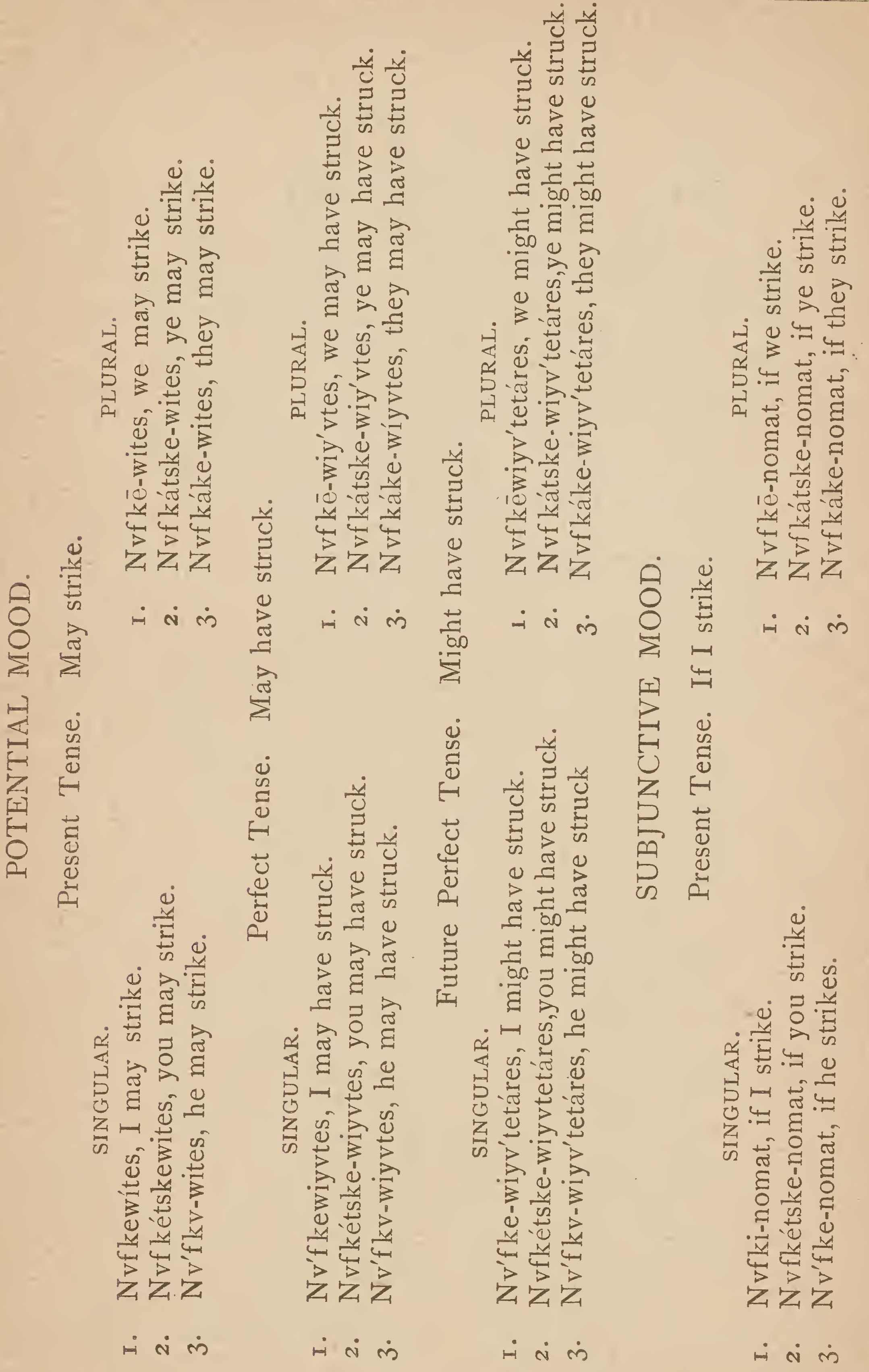




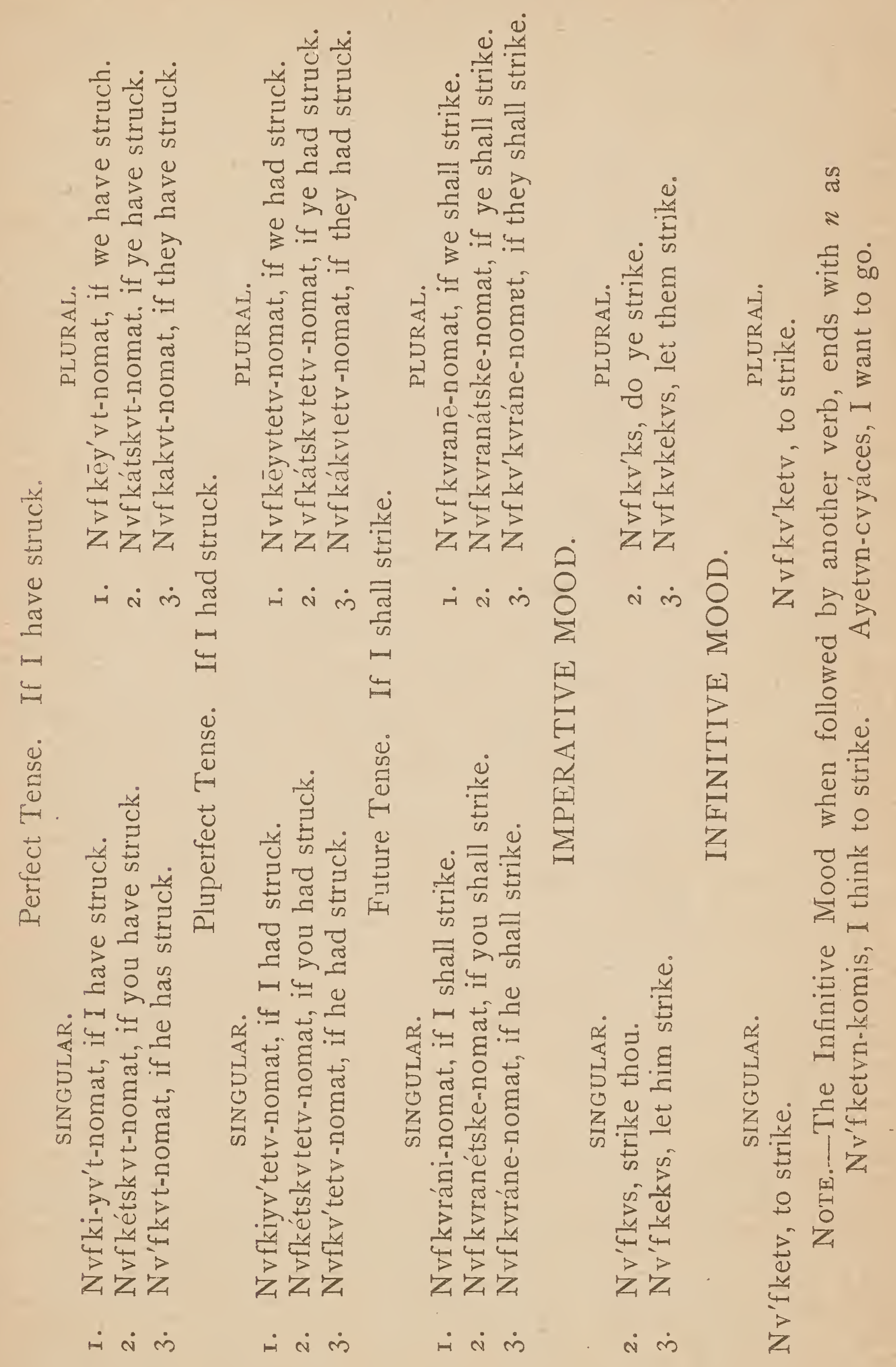




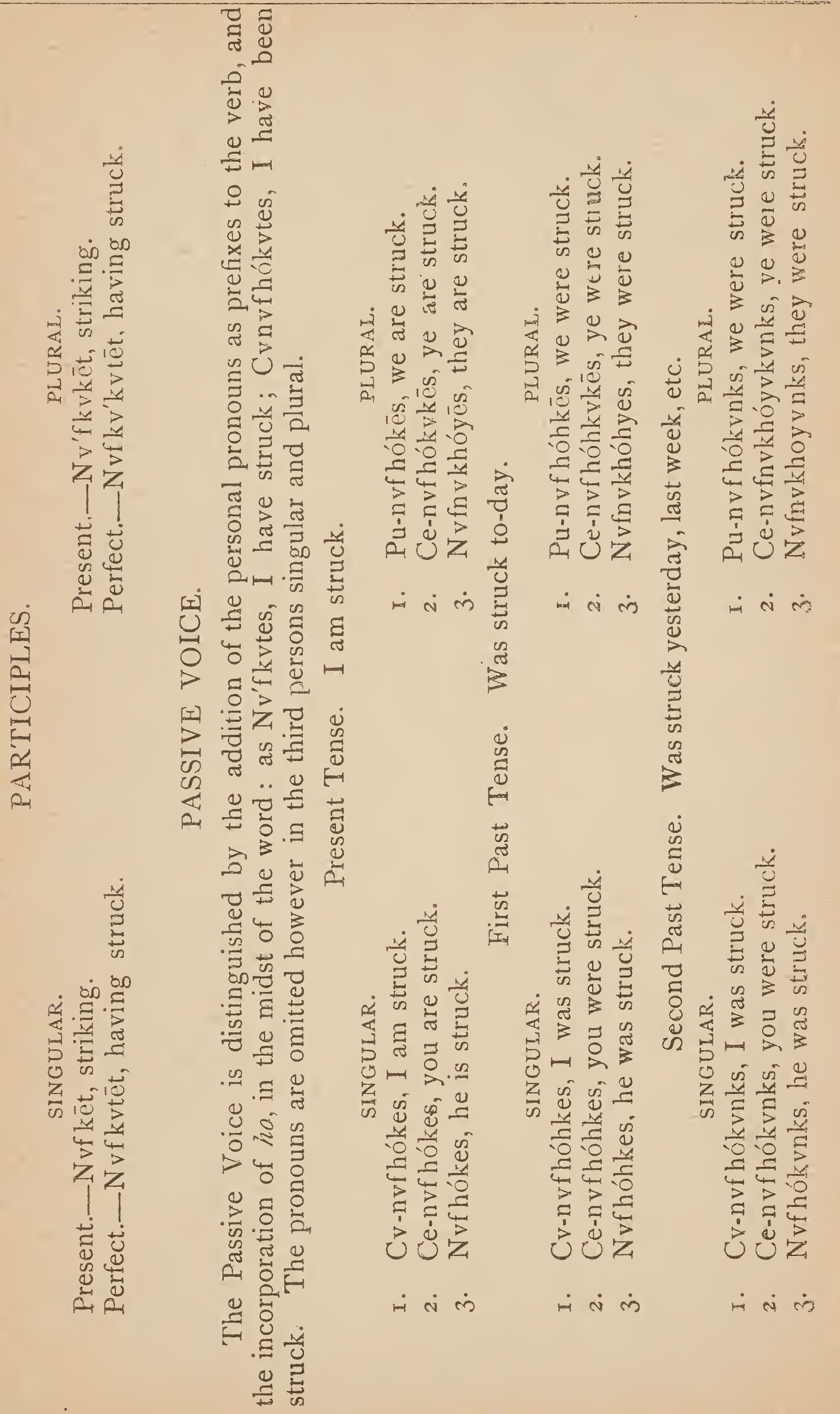




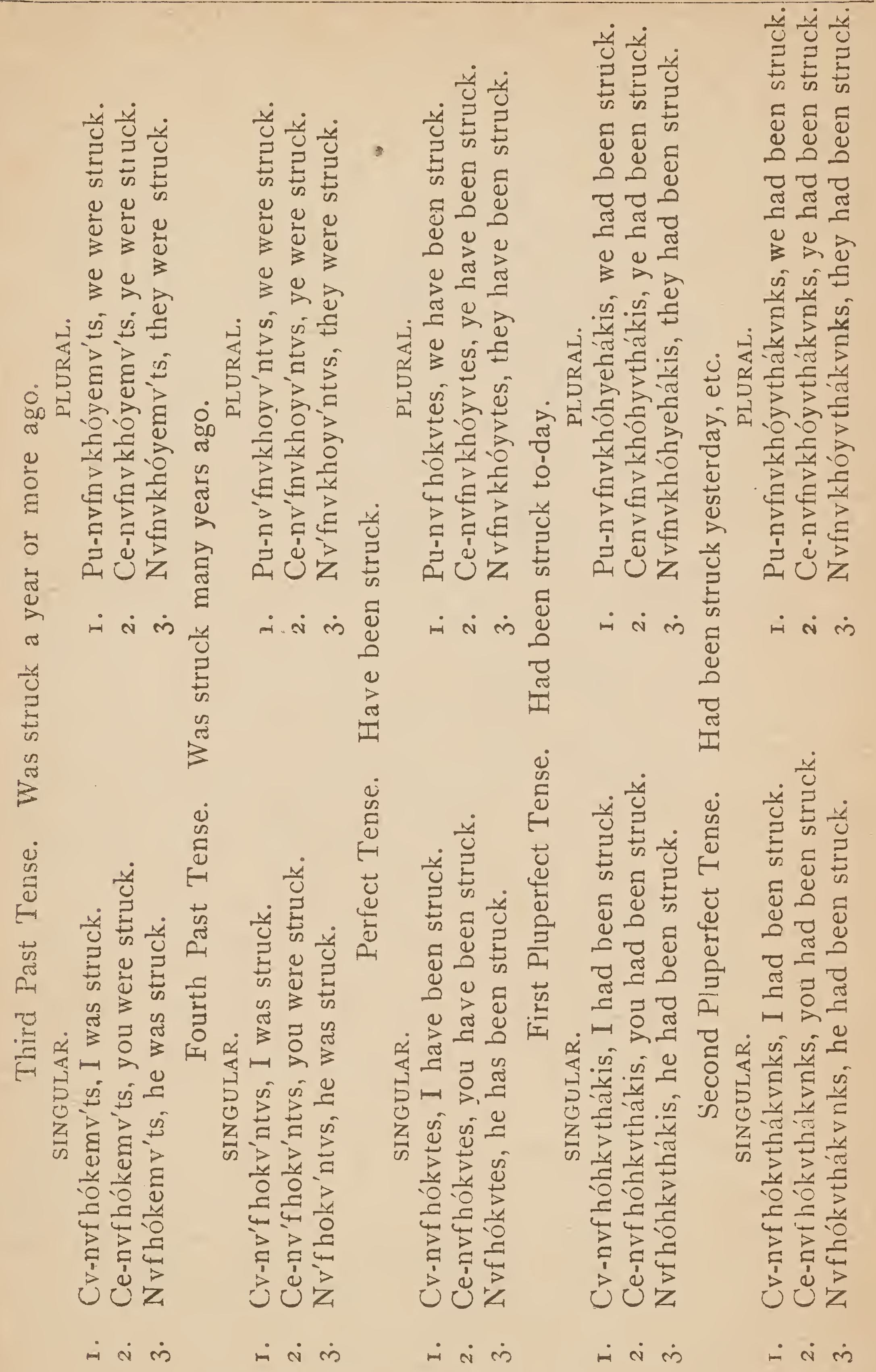




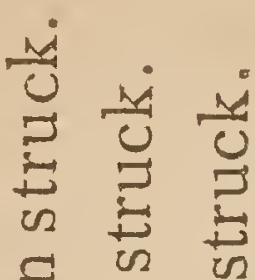

है)

๑)

苂

$\geqslant \geqslant 2$.

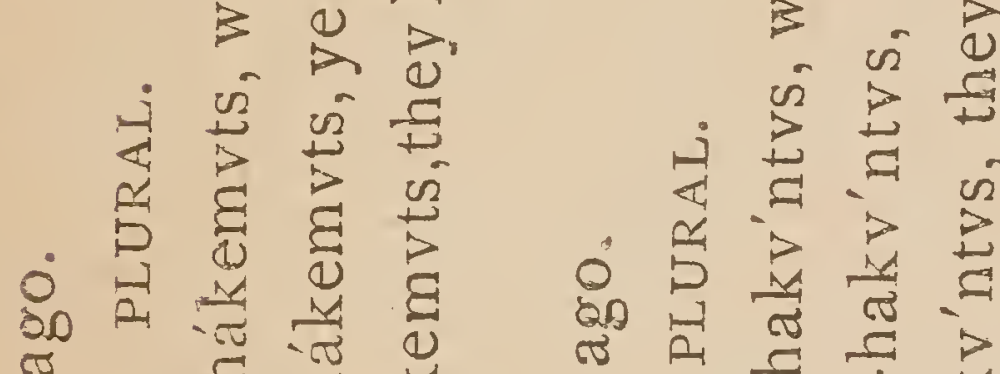

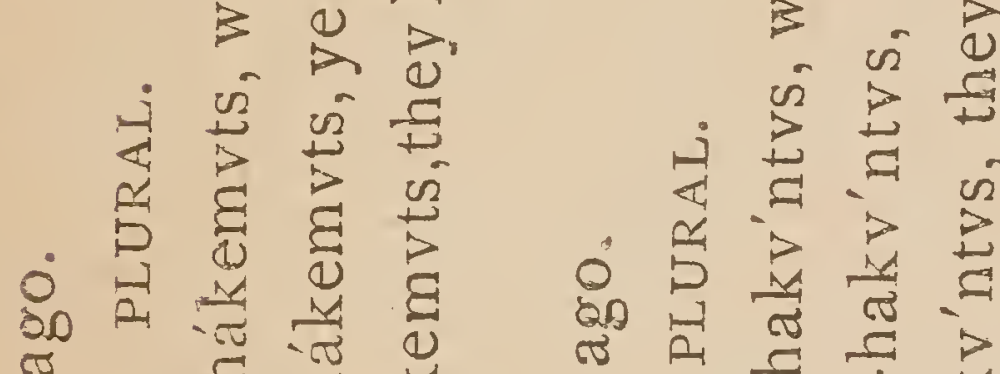

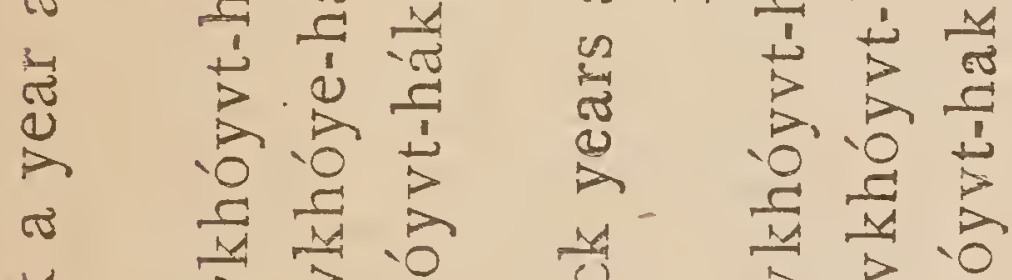

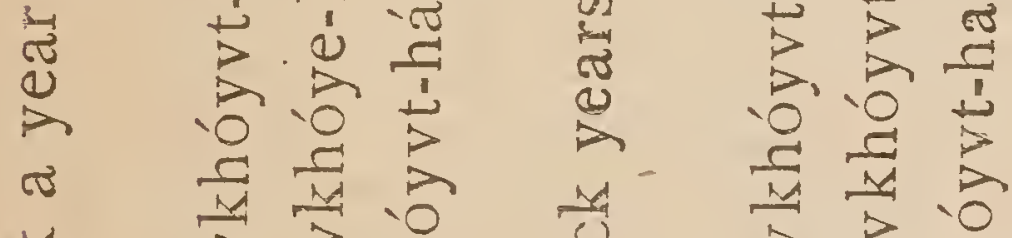

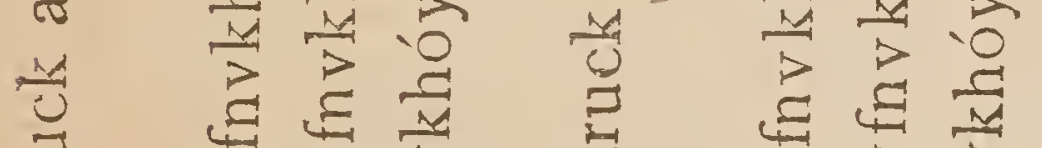

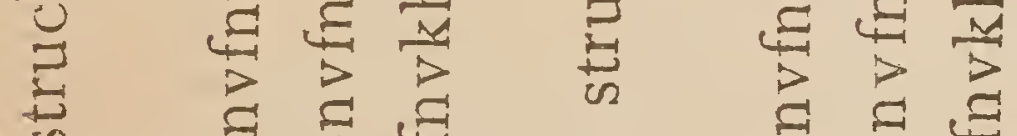

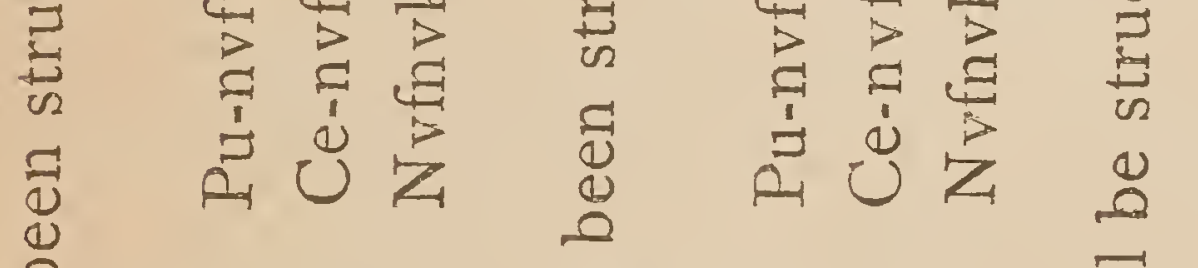

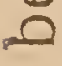

ت્ञ

过

这

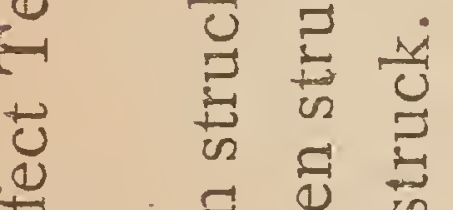

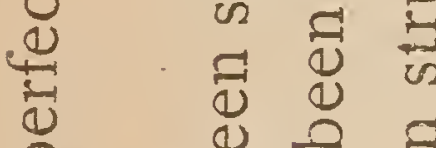

일

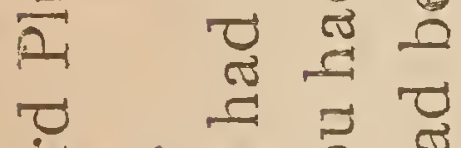

:

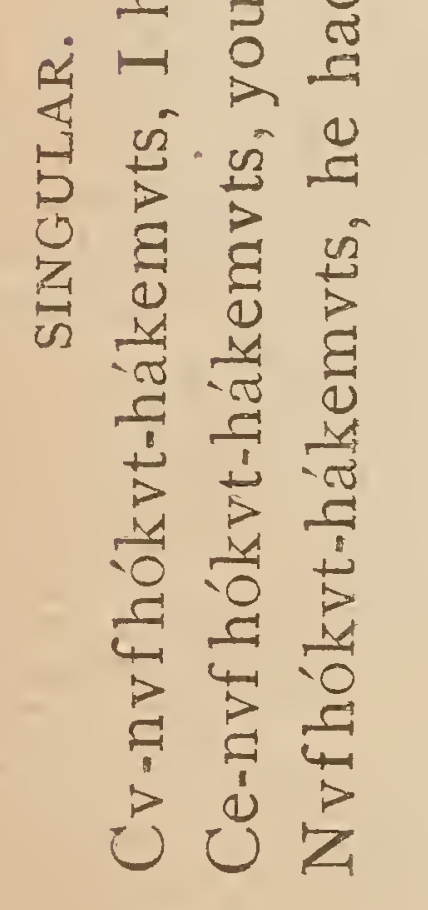

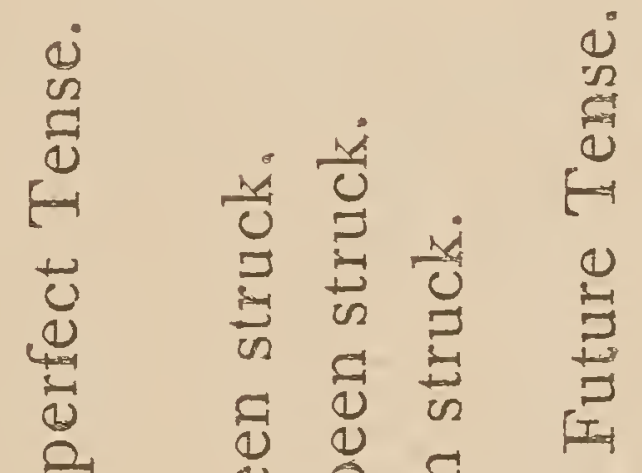

茫

ㄱ.

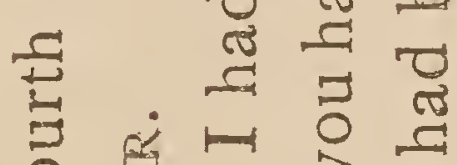

I.

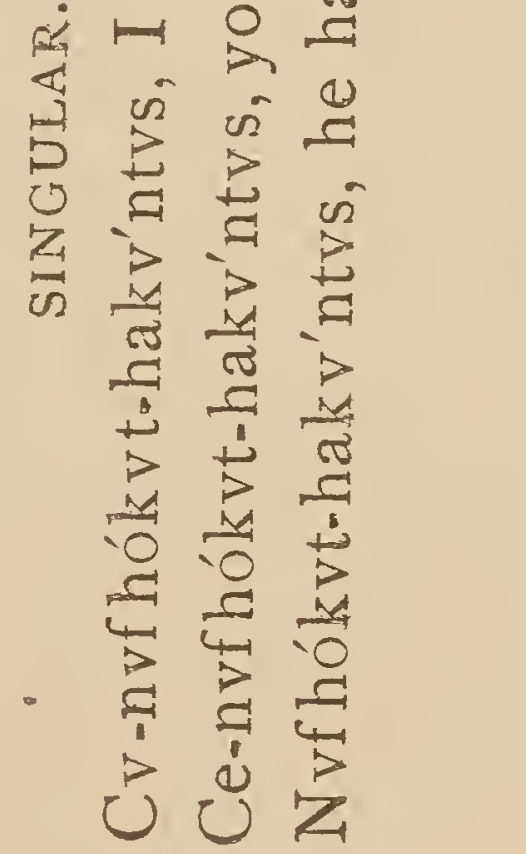

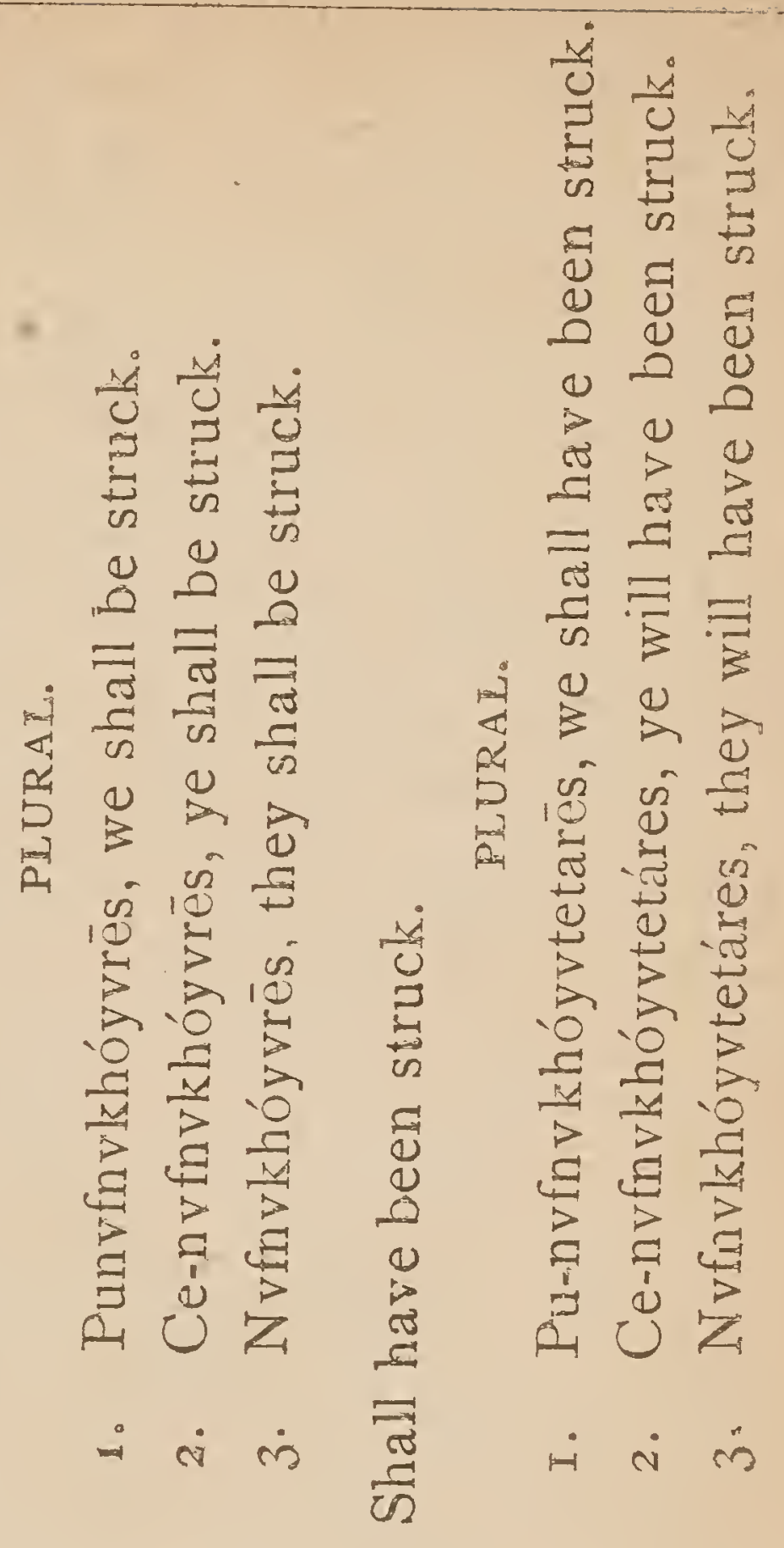

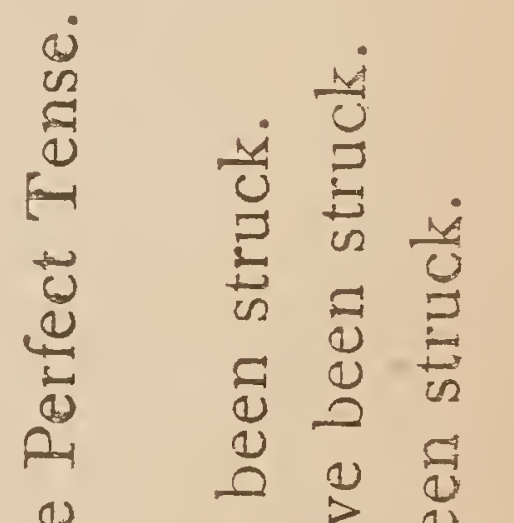

$\begin{array}{llll}0 & 0 & 1 & 0 \\ 3 & 0 & 0 & 0\end{array}$

$\vec{z}$

$\stackrel{\underline{I}}{\underline{I}} \equiv$

政

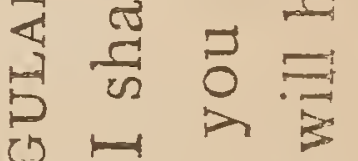

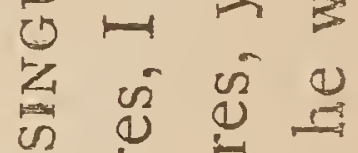

焉焉

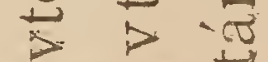

$\frac{\pi}{0} \div \frac{\pi}{0}$

द्य

:

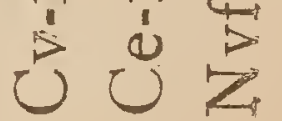

$\dot{\sim} \dot{\sim} \dot{m}$

$\dot{m} \dot{\dot{m}} \dot{m}$

$\dot{A}$ i $\dot{\text { is }}$ 


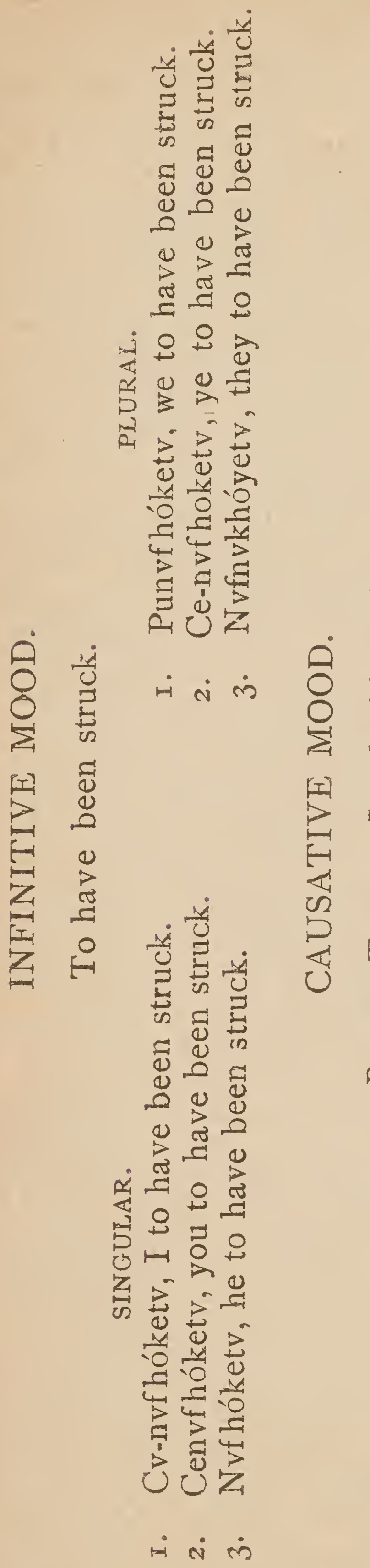

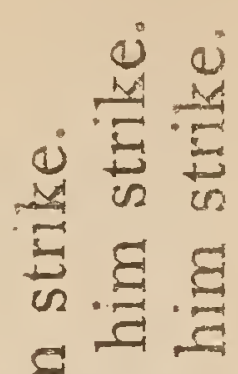

है)

$\rightarrow \frac{\pi}{\pi}$

政

열

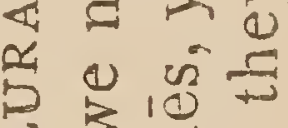

$\rightarrow 34$ in के

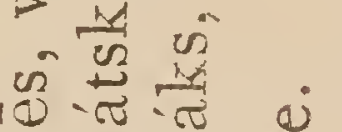

U.

요용

त

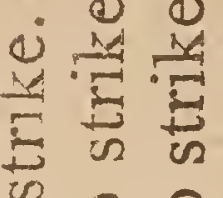

i $x$

焉落

․․ㄹ.

次

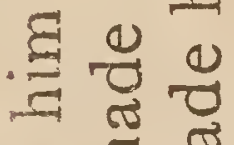

\& छ छ

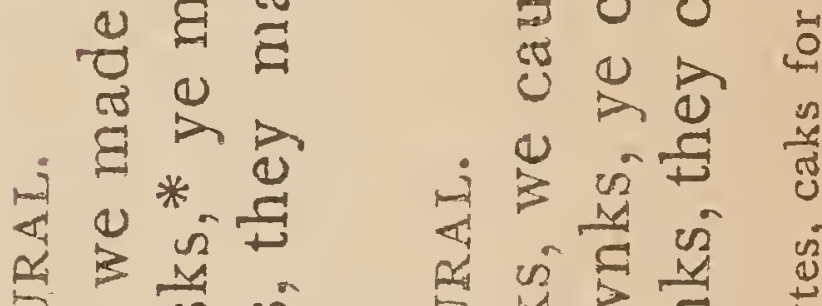

\& \& \&

\&

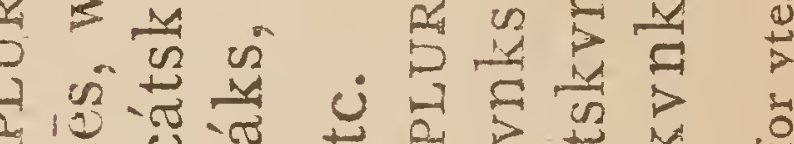

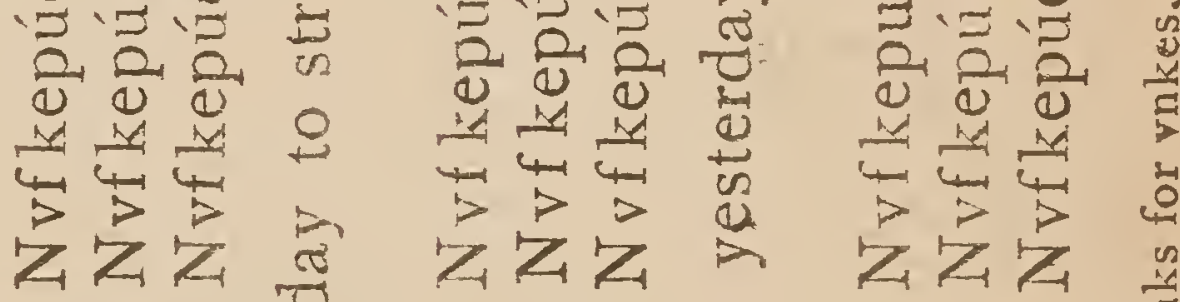

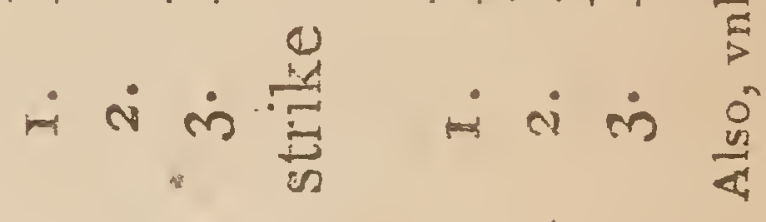

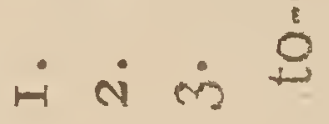

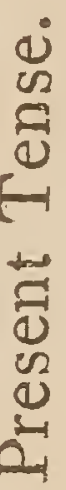

过造造

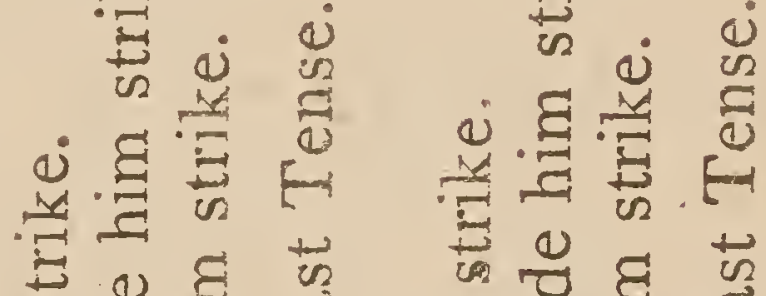

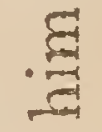

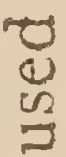

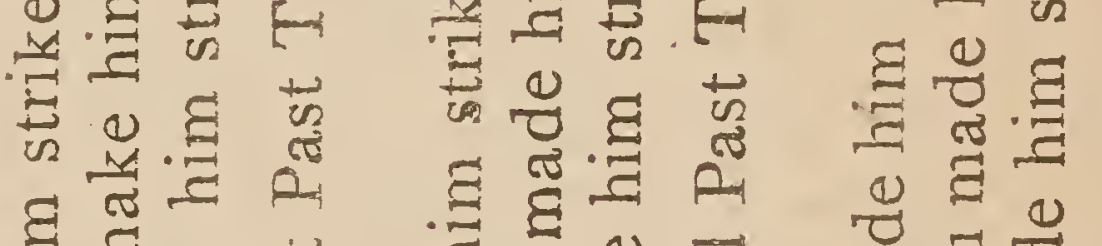

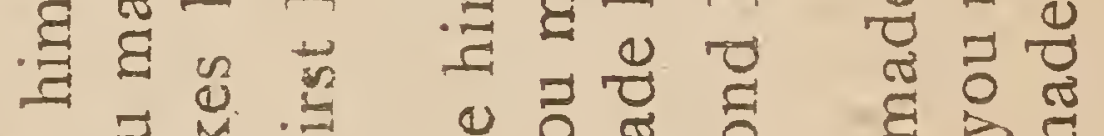

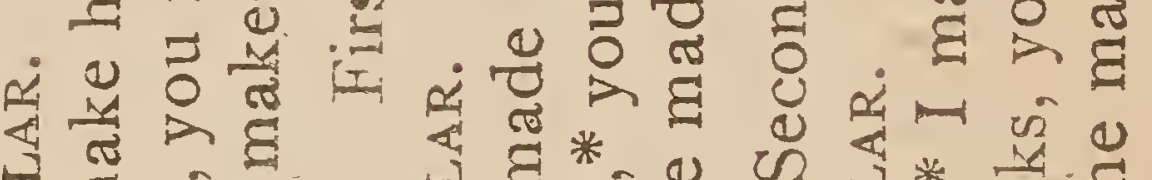

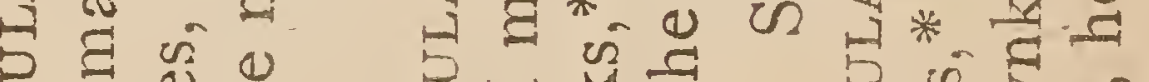

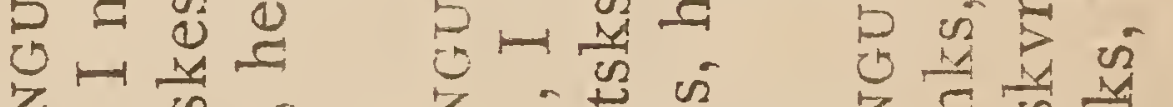
क. 站

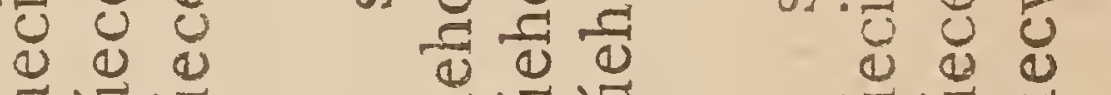

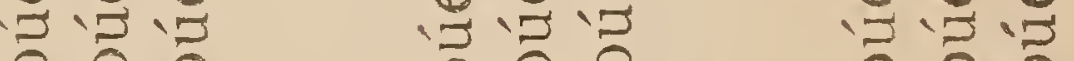

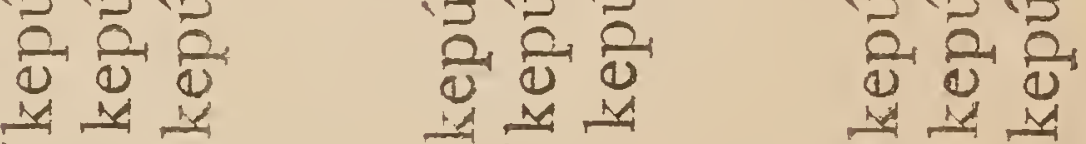

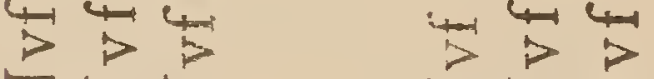

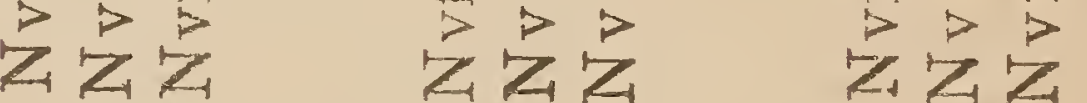
. 


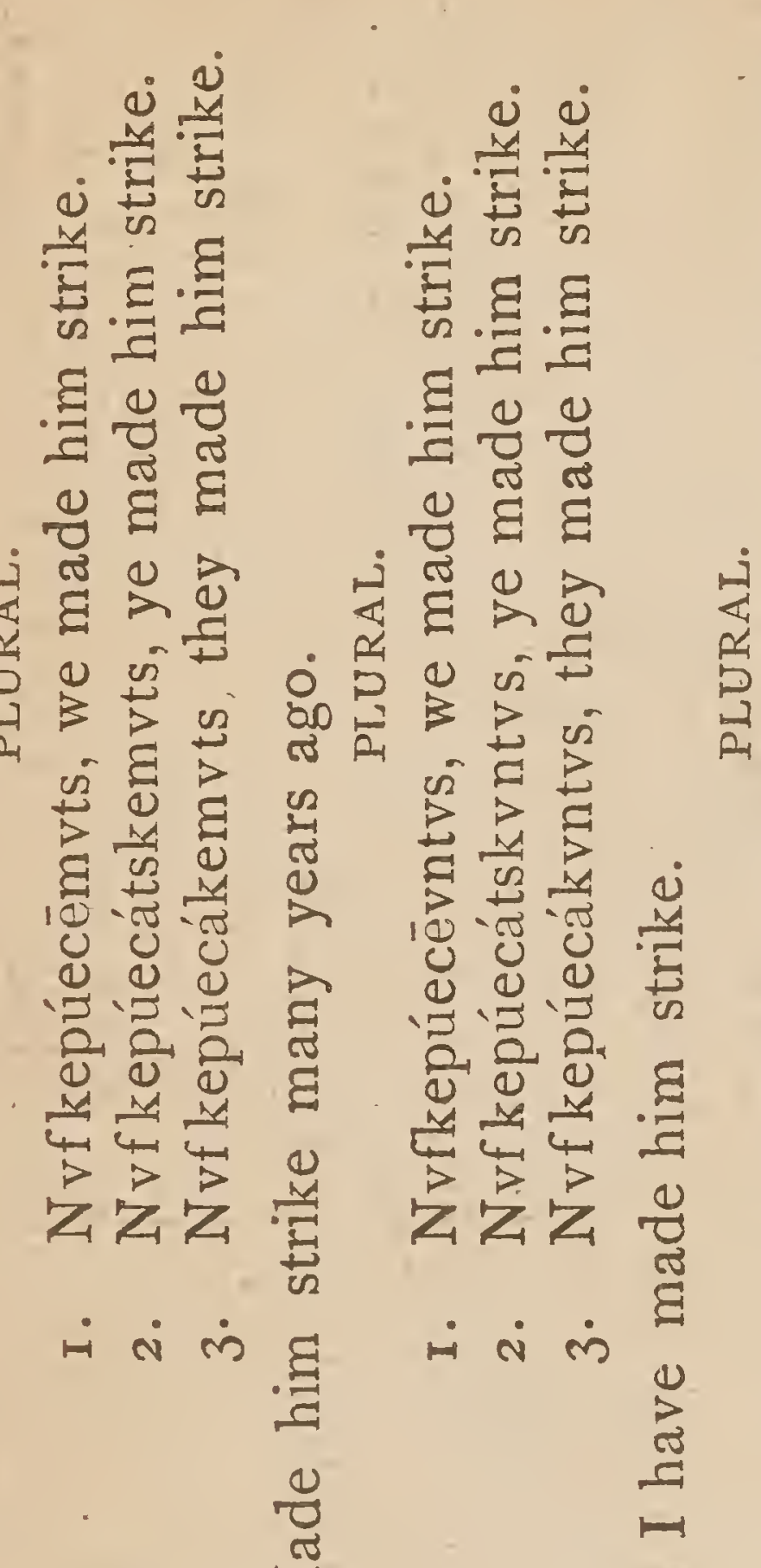

带

نี

$E$

悹

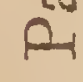

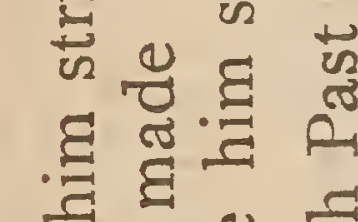

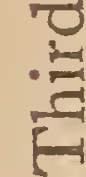

ن. है थै

$\stackrel{1}{=1}$

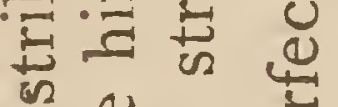

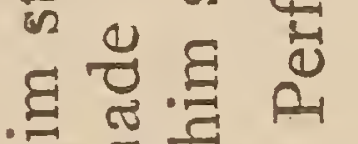

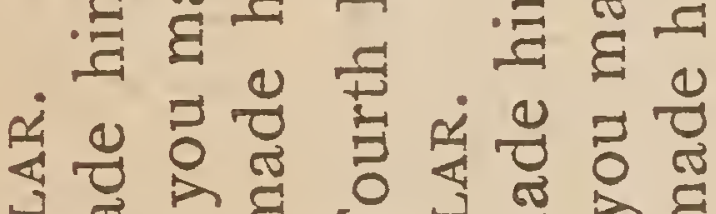

म
ن $ن \dot{~}$

部焉

हี.

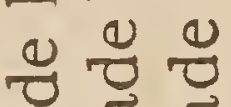

है हृ

(1) 10

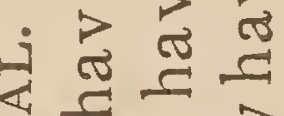

낭

๑ 3 क

is

$\stackrel{2}{2} \stackrel{2}{2}$

$3 \sqrt{2}$

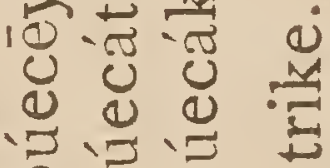

글

$\underset{4}{4} \frac{1}{b}$ 嵌

Z市

$\dot{A} \dot{\alpha} \dot{m}$

i $\quad \dot{0} \quad \dot{4}$

i)

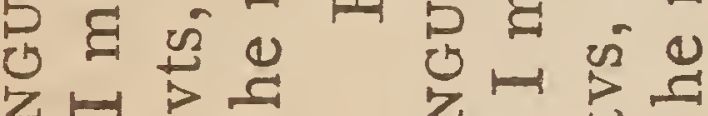

药

$3 \frac{\pi}{2}$ ह

हु)

U U 0

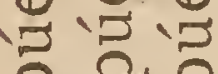

언 언 원

는

$\rightarrow+4$

ZZZ

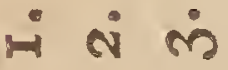

点点点

30

(4)

ำ ำ

는

$\rightarrow 3$

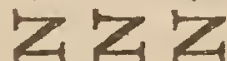

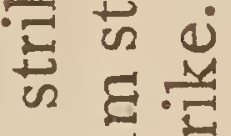
ह.

要造 幽岸 是范

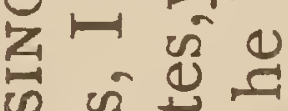
过艺 क 3 ज्ञ 过范 U U U

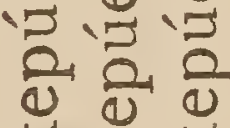
난

$\rightarrow>3$ ZZZ
욜 0 드

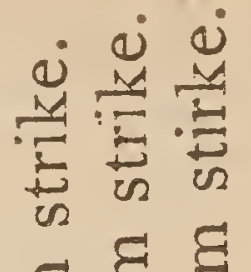

छ छ छ

(1)

तै चु

ह छ

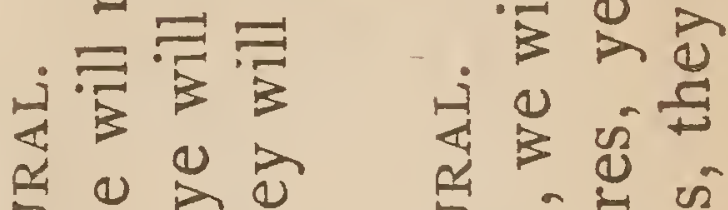

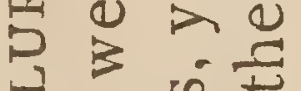

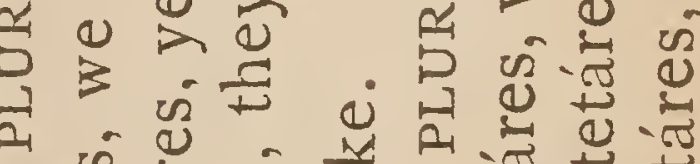
य 2 की

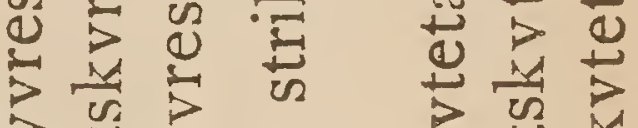
(1). บ บ E

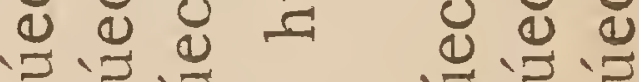

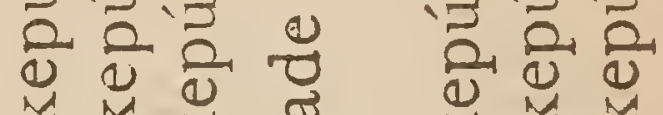

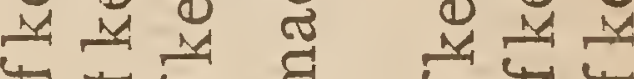
$\rightarrow>4$ 至 $\quad 4>$ ZZZ 只ZZ

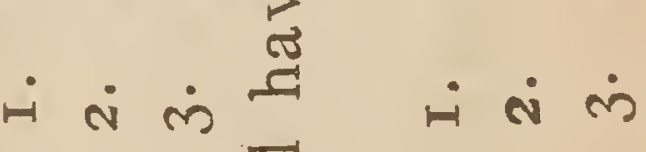

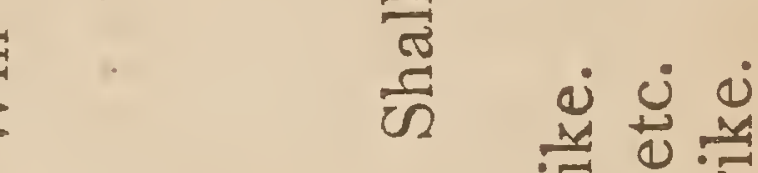

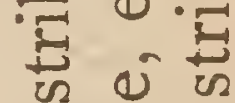
i $\quad \dot{0}: \dot{0}$ थ

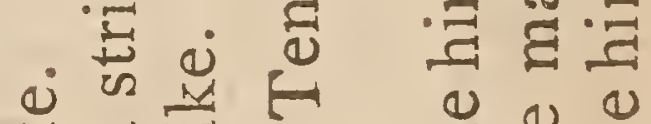

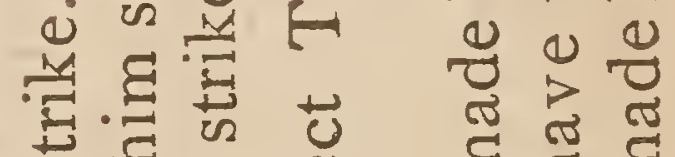
थ ह

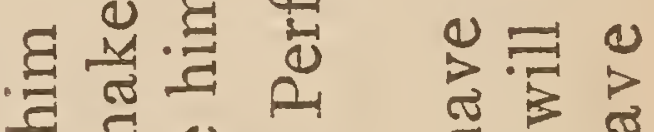

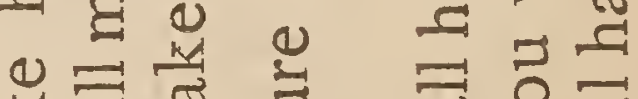

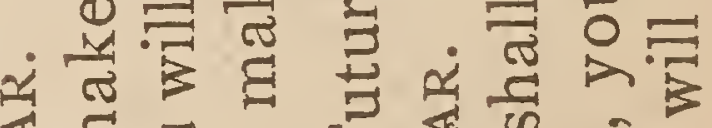
है

D $=2: 3$

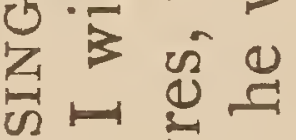

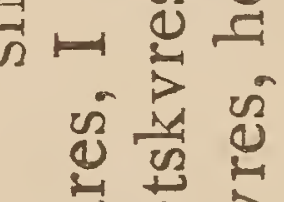

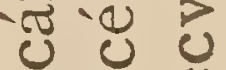

บ

ชิ ชิ ช

स्ष

44

吕兵

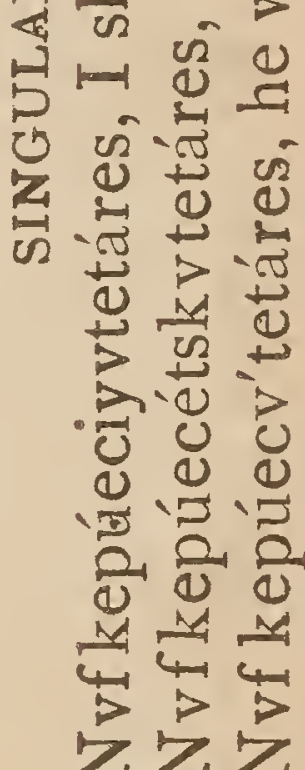

$\dot{4} \dot{\mathrm{r}}$

$\dot{-i} \dot{\mathrm{n}}$

$\dot{i} \dot{i} \dot{~}$ 


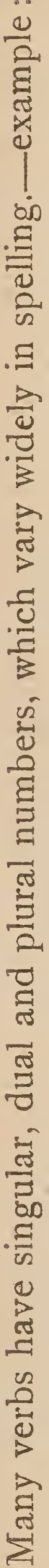

ن. ن⿺辶寸

宾密密芯

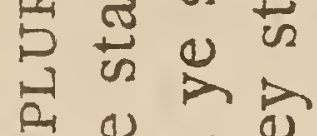

$\frac{10}{4} \cdot \frac{\pi}{10}$

些

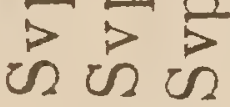

$\dot{i} \dot{\mathrm{i}} \dot{\mathrm{m}}$

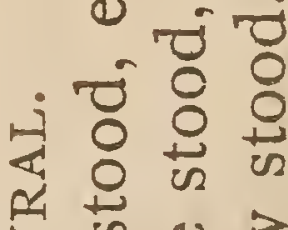

का

$\cdot \frac{2 \pi}{2} \frac{\pi}{\sqrt{2}} \cdot \frac{2}{\pi}$

is $-\pi$

굴

诰识
- 0 - 0 தं

3 is

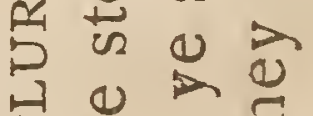

2.

$\dot{i} \dot{\sim} \dot{m}$

ن 选选 离

安

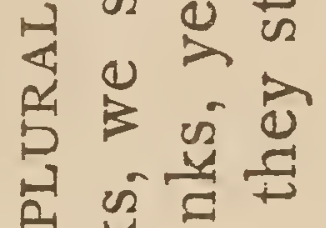

空糙

定索要

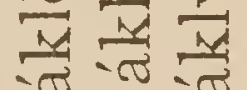

类

证初

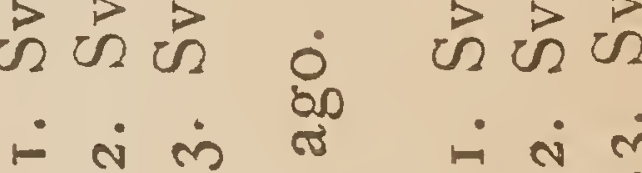

is

范范

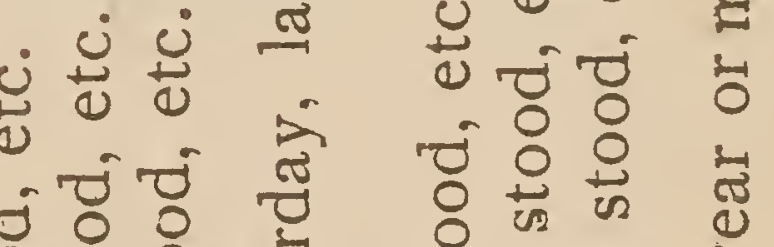

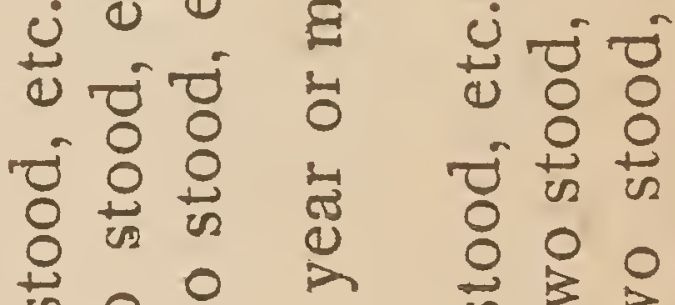

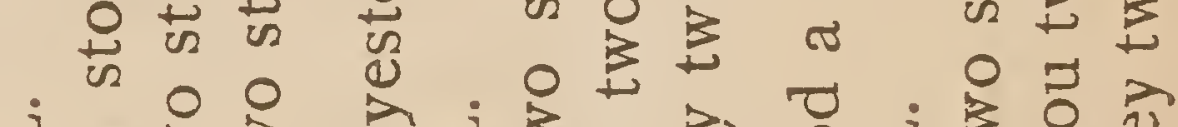

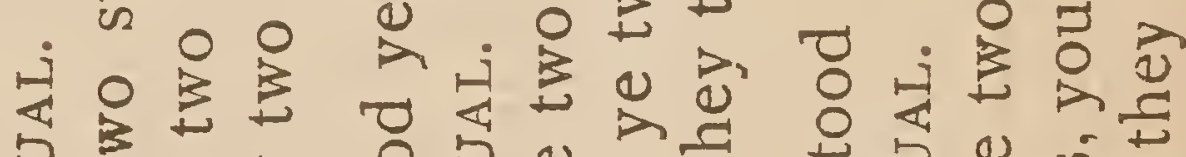

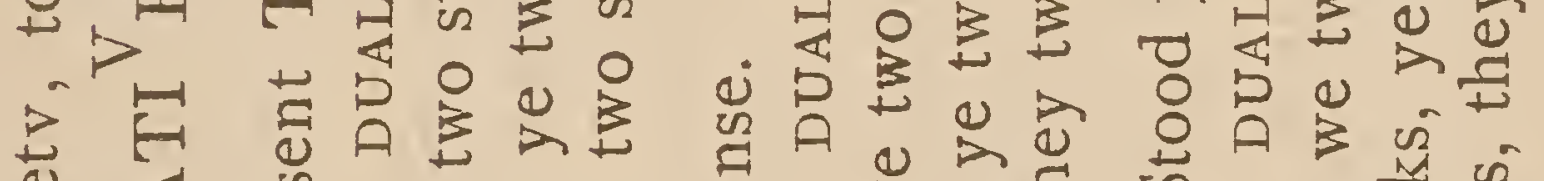

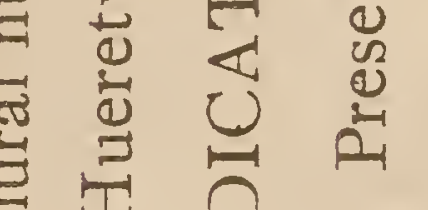

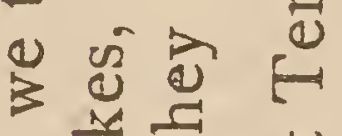

की

की की की की

का

娄, की

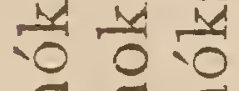

बह

$\dot{i} \dot{\sim} \dot{m}$

范

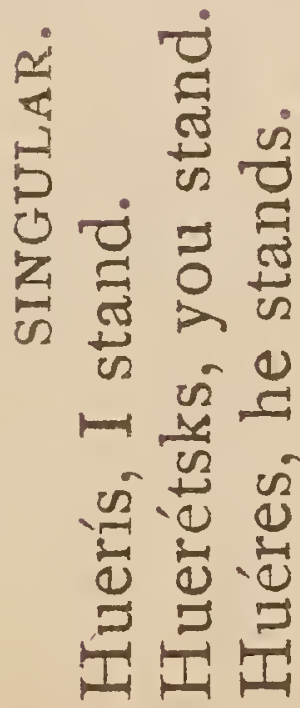

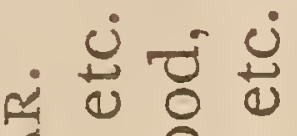

a. $\frac{\pi}{\pi}$

응

द

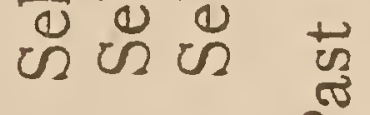

$\dot{H} \dot{\mathrm{N}}$

导

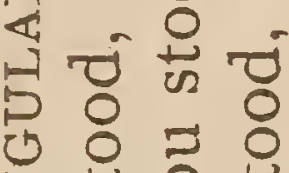

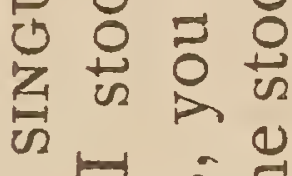

in

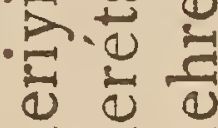

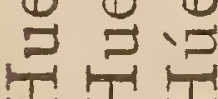

$\dot{\alpha} \dot{\alpha}$ tis

娄

때용

造造

$\dot{\sim} \dot{\alpha}$ 的

i $>$

पूत है

() $-\frac{\pi}{-\pi}$

능 능

政

ก $\backsim$

¿ீ่

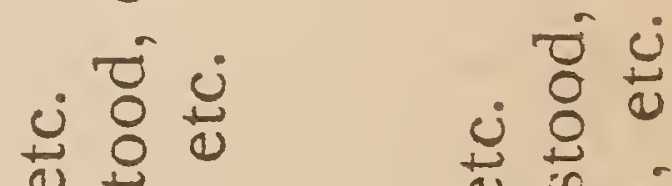
它员的

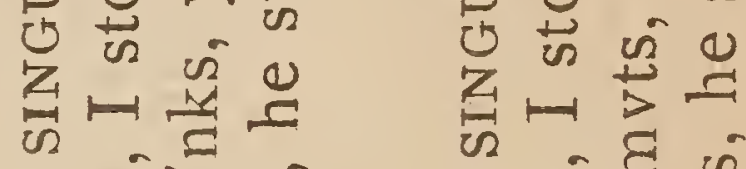
至空 击 过导 氙志

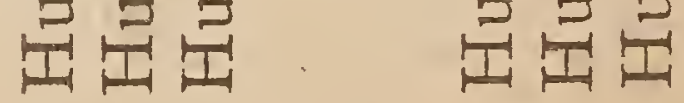
$\dot{\sim} \dot{\mathrm{m}} \dot{\mathrm{N}} \dot{\mathrm{N}}$

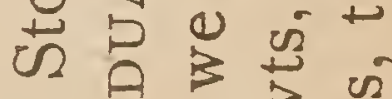

का है

$\dot{\sim} \dot{\alpha} \dot{~}$ 范范 定员员品 
.

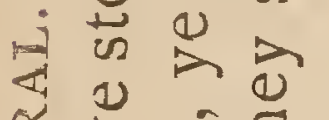

告业

कi n

焉吾

3 出

10.

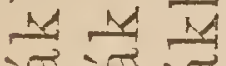

$0 \Omega$

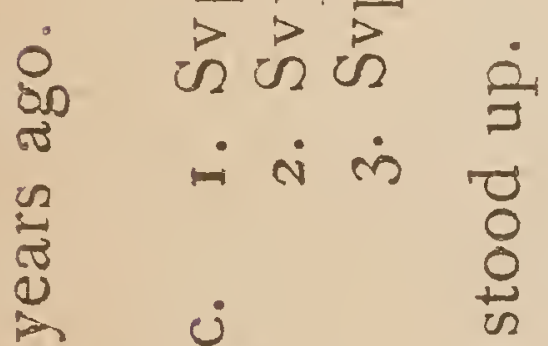

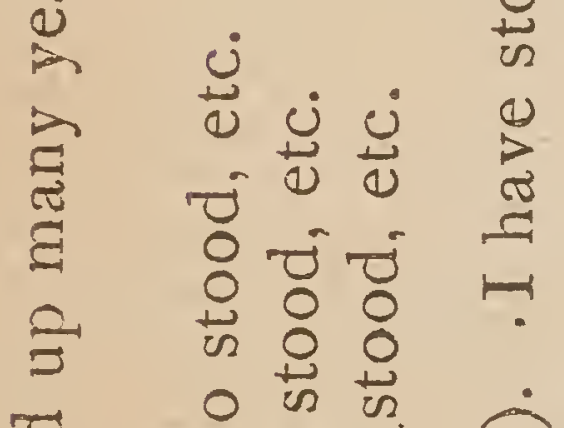

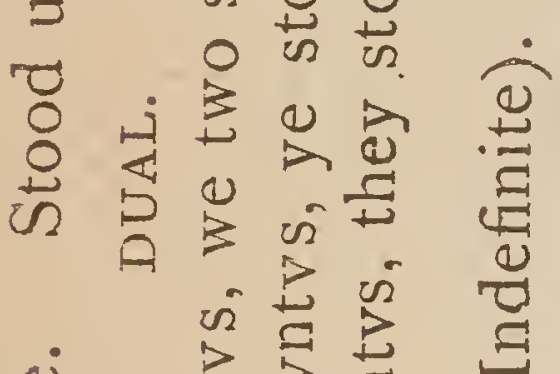

(2)

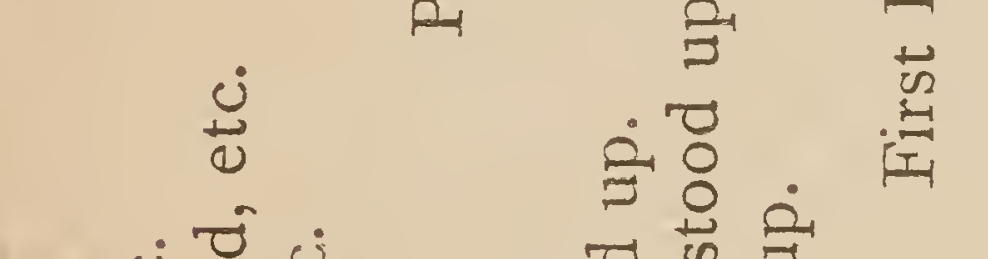

نُ

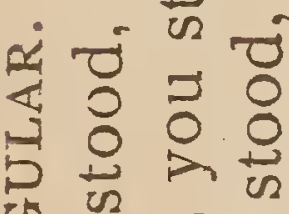

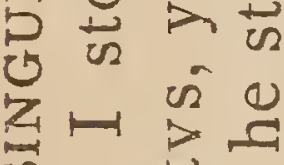

v

站会

$>+\frac{1}{b}$

눤

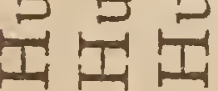

$\dot{4} \dot{0}$ $\dot{\check{7}}$

70

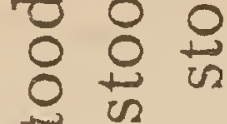

in

在

过

政

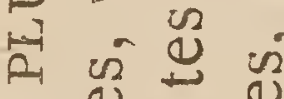

$\triangle 5$

3.

군

然

踏学

$\dot{\alpha}$ वं

ن⿺辶

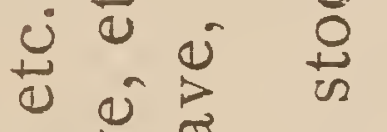

(i) $\frac{1}{2}$

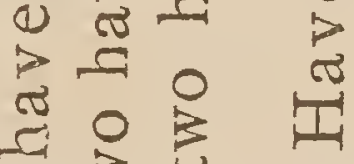

要

年

녕

$\circ$ 잉

$\therefore$ य

$\Rightarrow \geqslant$

$b$ 品

到

so

5 然

密离

出出出

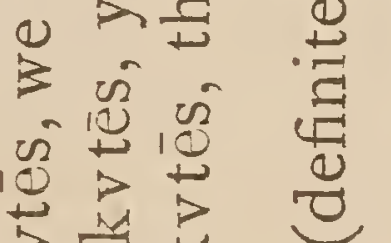

욜

可

年

is

政

政

西 $\pi$

की

म्वं

(j)

बे

(0)

家

)

웅요

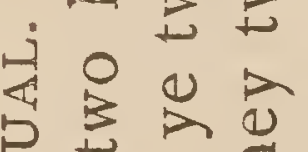

0.73

$\geqslant 100$

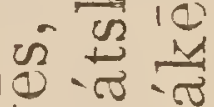

每

a

西

ऊँ

में के $\underset{0}{0}$

نَّ

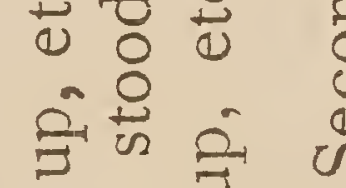

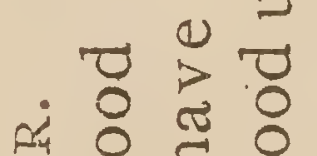

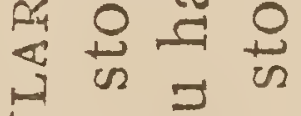

否品骂骂

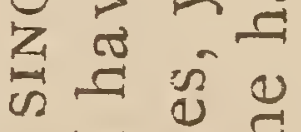

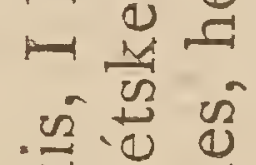

音诸

可

出出告

$\overrightarrow{0}$
0
0
0
0
0
0
3
3
0
0
0
0
0
0
0
0
0

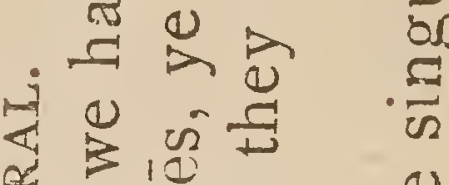

का

光

$>$ त्

플 복

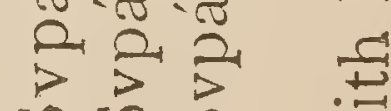

的你

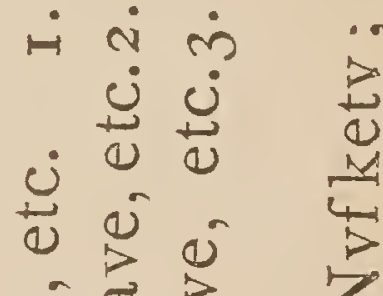

0

고요

年

हD

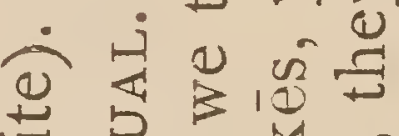

in

10

光 $\frac{M}{5}$

,

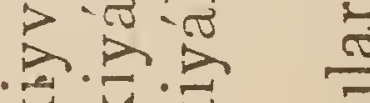

슴 $y$

웅엉

षब ब

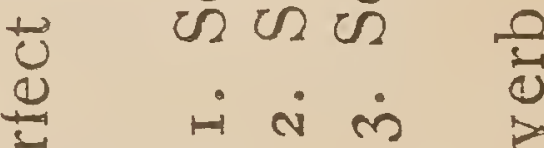

苍苍芯 包

हीं ई

D

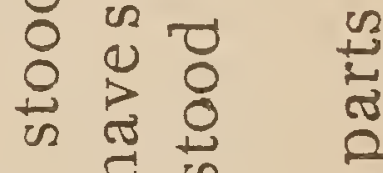

ये क्ज

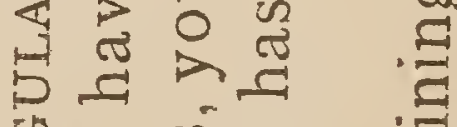

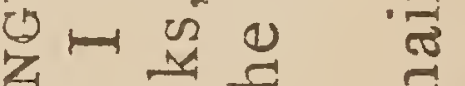

光 क्ष

दी की क्षे

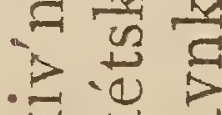

番

峁

正正正

$\dot{m} \dot{\sim} \dot{m}$

$\dot{\theta} \dot{\alpha} \dot{m}$

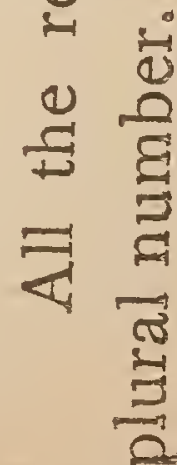








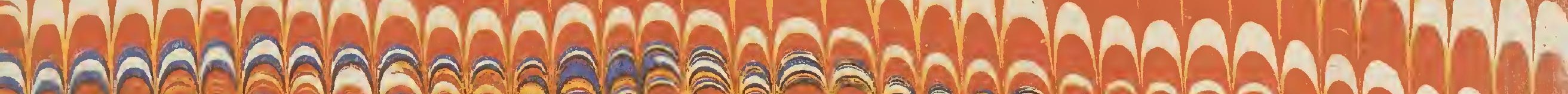

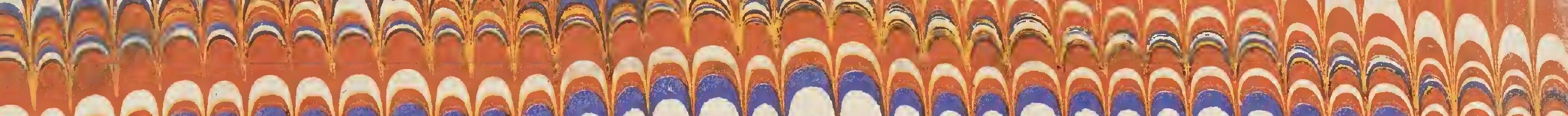

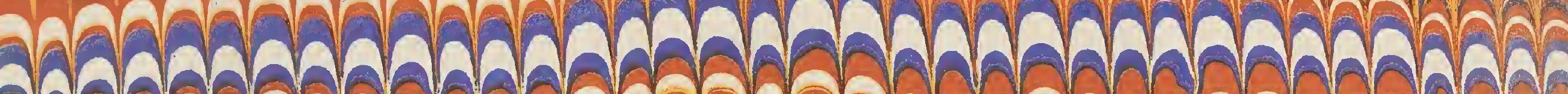

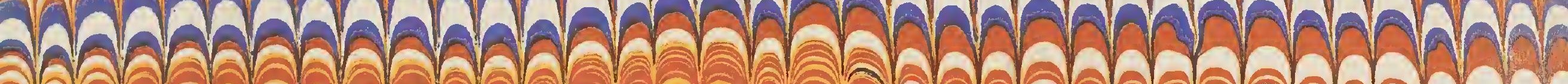

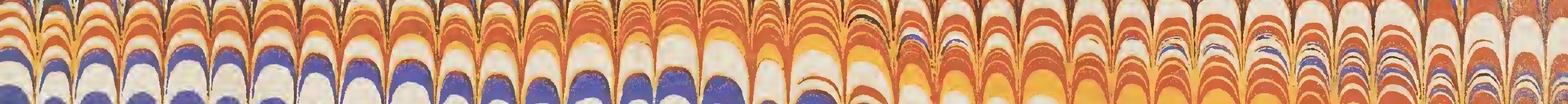
ฟhahan

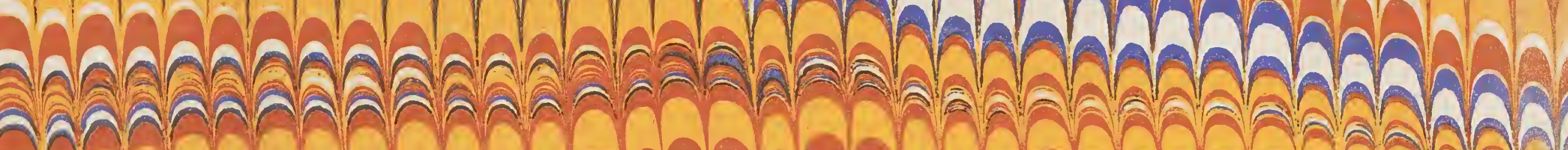

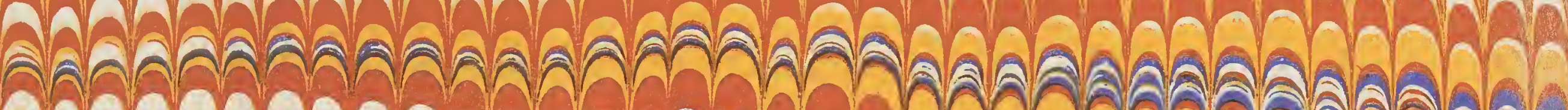
กิ

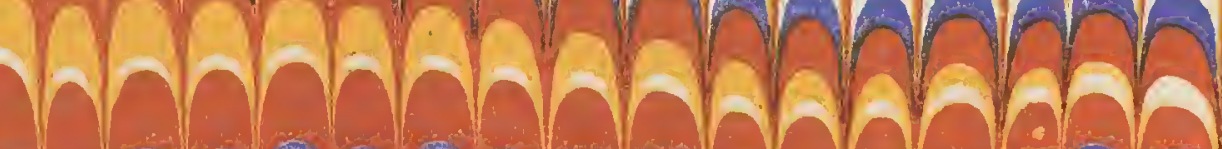

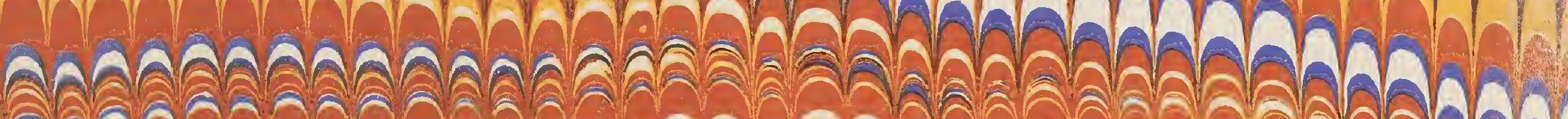
manazanananafan

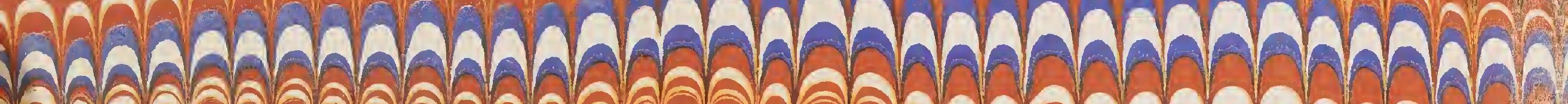
ลลล MaAna

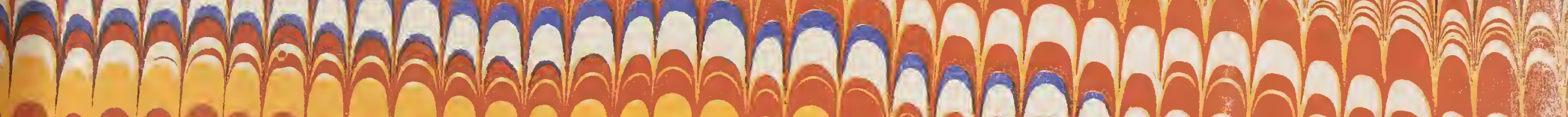
an-

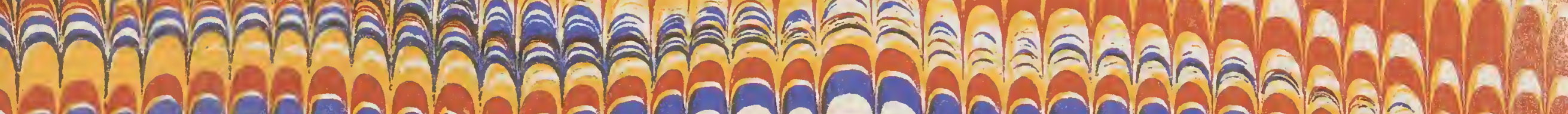
12.

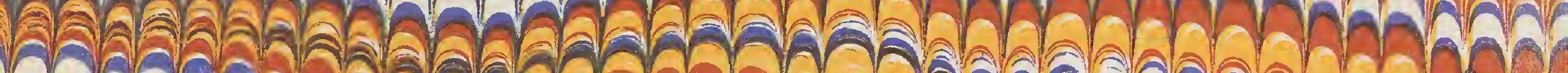
คด Thanananan 12

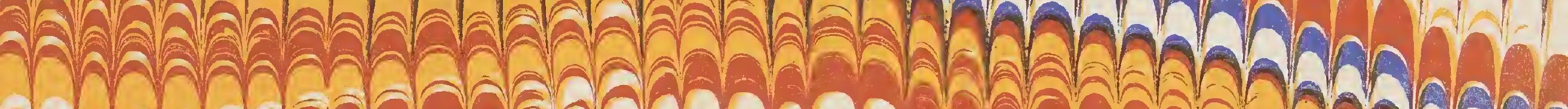

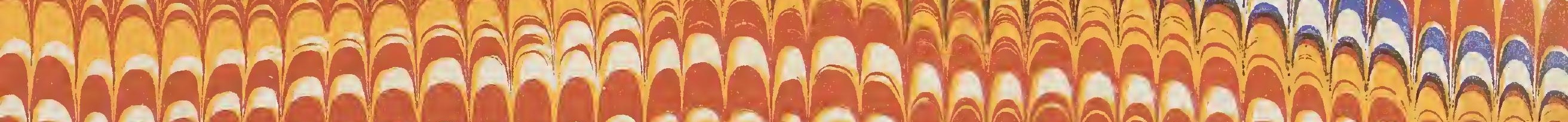

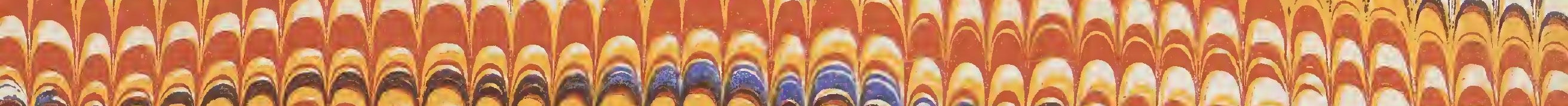

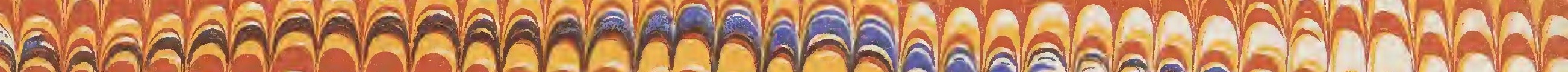

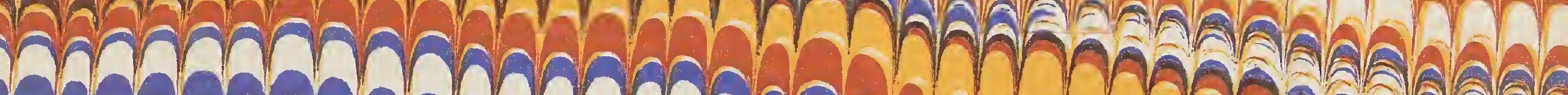
RARคA

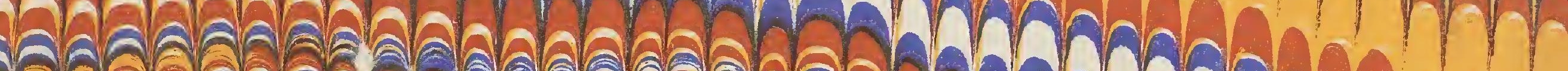

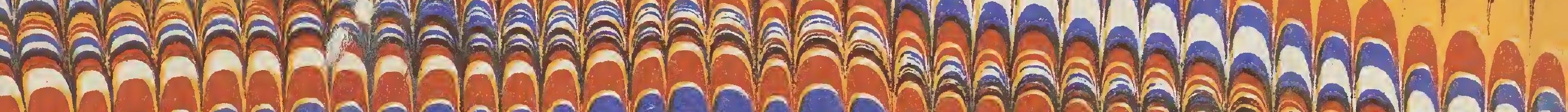

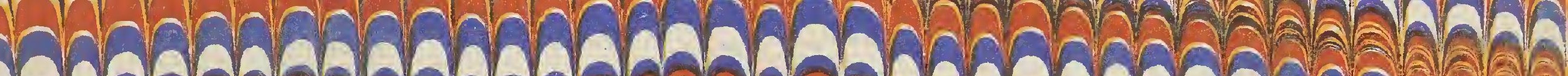


